\title{
DISCLAIMER
}

EGG.2441

This report was prepared as an account of work sponsored by an agency of the United States

Government. Neither the United States Government nor any agency thereof, nor any of their employees, makes any warranty, express or implied, or assumes any legal liability or responsibility for the accuracy, completeness, or usefulness of any information, apparatus, product, or process disclosed, or represents that its use would not infringe privately owned rights. Reference herein to any specific commercial product, process, or service by trade name, trademark, manufacturer, or otherwise does not necessarily constitute or imply its endorsement, recommendation, or favoring by the United States Government or any agency thereof. The views and opinions of authors expressed herein do not necessarily state or reflect those of the United States Government or any agency thereof.

\section{EXTENDED LIFE ALUMINIDE FUEL FINAL REPORT}

L. G. Miller

J. M. Beeston

EG\&G Idaho, Inc. Idaho Falls, Idaho 83415

Prepared for the

U.S. Department of Energy Idaho Operations Office Under DOE Contract No. DE-AC07-ID01570 


\section{DISCLAIMER}

This report was prepared as an account of work sponsored by an agency of the United States Government. Neither the United States Government nor any agency Thereof, nor any of their employees, makes any warranty, express or implied, or assumes any legal liability or responsibility for the accuracy, completeness, or usefulness of any information, apparatus, product, or process disclosed, or represents that its use would not infringe privately owned rights. Reference herein to any specific commercial product, process, or service by trade name, trademark, manufacturer, or otherwise does not necessarily constitute or imply its endorsement, recommendation, or favoring by the United States Government or any agency thereof. The views and opinions of authors expressed herein do not necessarily state or reflect those of the United States Government or any agency thereof. 


\section{DISCLAIMER}

Portions of this document may be illegible in electronic image products. Images are produced from the best available original document. 


\begin{abstract}
As the price of fuel fabrication, shipment of both new and spent fuel, and fuel reprocessing continue to rise at a rapid rate, researchers look for alternate methods to keep reactor fuel costs within their limited funding. Extended fuel element lifetimes, without jeopardizing reactor safety, can reduce fuel costs by up to a factor of two. The Extended Life Aluminide Fuel (ELAF) program was started at the Idaho National Engineering Laboratory (INEL) as a joint project of the United States Department of Energy (DOE), the University of Missouri, and the Massachusetts Institute of Technology research reactors. Fuel plates of Advanced Test Reactor (ATR) type construction were fabricated at Atomics International and irradiated in the ATR at the INEL. Four fuel matrix compositions were tested (i.e., $50 \mathrm{vol}^{\%} \mathrm{UAl}_{\mathrm{x}}$ cores for reference, and 40,45 and 50 vol\% $\mathrm{UAl}_{2}$ cores). The $50 \mathrm{vol}_{0} \mathrm{UAl}_{2}$ cores contained up to 3 grams $\mathrm{U}$ 235 per $\mathrm{cm}^{3}$ of core. Three plates of each composition were irradiated to peak burnup levels of $3 \times 10^{21}$ fission $/ \mathrm{cm}^{3}$ of core. The only observed damage was due to external corrosion at similar rates experienced by $\mathrm{UAl}_{\mathrm{x}}$ fuel elements in test reactors.
\end{abstract}




\section{SUMMARY}

The Extended Life Aluminide Fuel (ELAF) program was started at the Idaho National Engineering Laboratory (INEL) as a joint project of the United States Department of Energy (DOE), the University of Missouri, and the Massachusetts Institute of Technology. For the program, 30 fuel plates were constructed to a maximum fuel loading that could be produced on a commercial basis. These contained $\mathrm{UAl}_{2}$ and $\mathrm{UAl}_{3}$ fuel ( $\mathrm{UAl}_{\mathrm{x}}$ ) cores, with maximum boron content as used in the Advanced Test Reactor (ATR) at the Idaho National Engineering Laboratory. The maximum boron content was incorporated to reduce initial reactor reactivity. The $\mathrm{UAl}_{2}$ fuel core was used to gain higher uranium content. The test program was planned so that the fuel plates would be irradiated to a maximum fission density of $3-4 \times 10^{21} \mathrm{f} / \mathrm{cm}^{3}$ (about $50 \%$ burnup for the $50 \mathrm{vol} \%$ fuel plate cores). This burnup is about twice that presently allowed in university reactors.

An ELAF fuel core with $73 \mathrm{wt} \%$ of the brittle phase (UAl $)_{x}$ gave excellent performance to a burnup of $1.84 \times 10^{21} \mathrm{f} / \mathrm{cm}^{3}$ with a peaking factor of 1.63 (peak burnup of $\left.3.0 \times 10^{21} \mathrm{f} / \mathrm{cm}^{3}\right)$.

The ELAF fuel plates operated at surface temperatures of about $395 \mathrm{~K}\left(120^{\circ} \mathrm{C}\right)$ with the only evidence of failure due to pitting corrosion.

Blister temperatures from post irradiation tests of $763 \mathrm{~K}$ (for the $\mathrm{UAl}_{3}$ composition) and $776 \mathrm{~K}$ (for the $\mathrm{UAl}_{2}$ composition) indicated large margins of safety from overheating for short periods of time.

The 50 vol\% $\mathrm{UAl}_{2}$ composition plates performed as good, or better, than the $50 \mathrm{vol} \% \mathrm{UAl}_{3}$ composition plates and will provide higher fuel loading. Although pitting corrosion caused the failure of three plates of the $\mathrm{UAl}_{2}$ composition, a large pit that would have produced failure was found in the $\mathrm{UAl}_{3}$ composition.

Neither the pitting corrosion rate, or the probability of pitting, seemed any greater in the ELAF plates than fuel elements in other reactors when consideration is taken of the plate surface temperature and the time in the water.

Reaction of the $\mathrm{UAl}_{2}$ to produce $\mathrm{UAl}_{3}$ and the $\mathrm{U}_{1-\mathrm{x}} \mathrm{Al}_{4}$ defect phase causes an increase in core volume of 6 to $12 \%$. The core volume percent thus approaches 60 vol\% of the brittle constituent.

It is recommended that the specification for oxygen in the powder blends be examined with the view of reducing the allowed oxygen.

It is recommended that management of the fuel element irradiation sequence be considered as a way to reduce the depth of pitting corrosion and extending fuel element life. 


\section{ACKNOWLEDGEMENTS}

The authors would like to thank L. D. Koeppen and J. W. Rogers for contributing the section on Fission Product Radionuclide Distributions in ELAF Fuel Plates that is included in Appendix A. 


\section{CONTENTS}

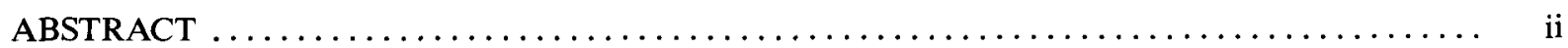

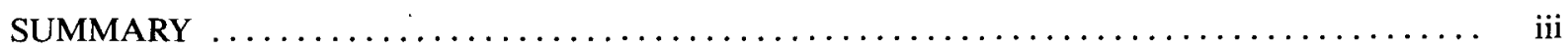

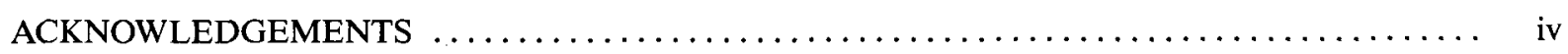

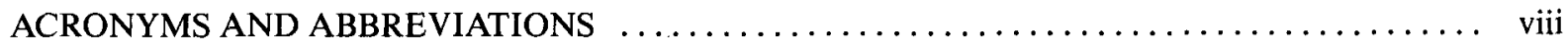

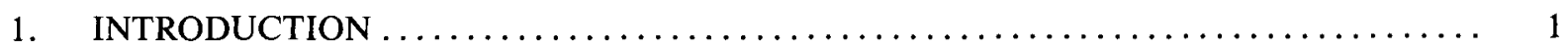

2. PLATE DESIGN AND IRRADIATION HISTORY $\ldots \ldots \ldots \ldots \ldots \ldots \ldots \ldots \ldots \ldots \ldots \ldots \ldots$

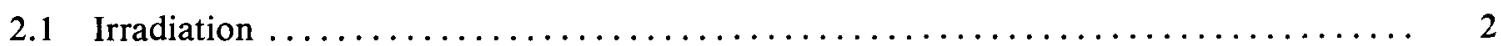

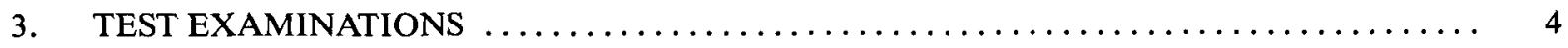

3.1 Visual Examination and Photography $\ldots \ldots \ldots \ldots \ldots \ldots \ldots \ldots \ldots \ldots \ldots \ldots \ldots \ldots \ldots \ldots$

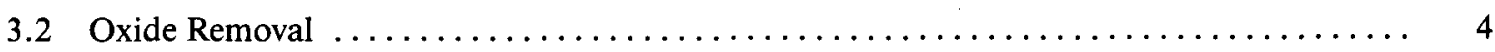

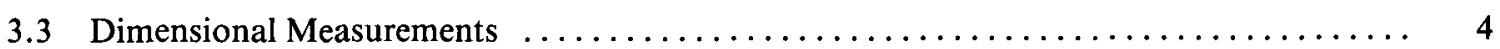

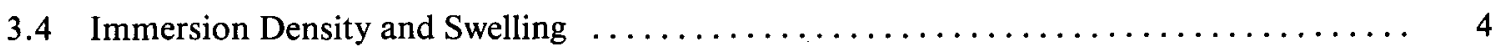

3.4.1 Swelling Determined from Thickness Measurements $\ldots \ldots \ldots \ldots \ldots \ldots \ldots . . \ldots$

3.4.2 Core Thickness Change by Metallography $\ldots \ldots \ldots \ldots \ldots \ldots \ldots \ldots \ldots$

3.5 Metallography $\ldots \ldots \ldots \ldots \ldots \ldots \ldots \ldots \ldots \ldots \ldots \ldots \ldots \ldots \ldots \ldots \ldots \ldots \ldots \ldots \ldots \ldots \ldots \ldots \ldots, 12$

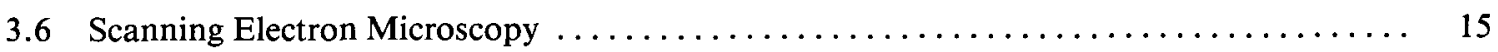

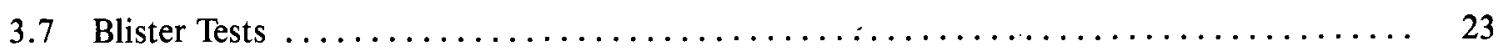

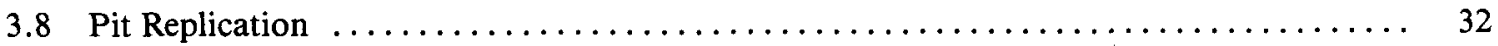

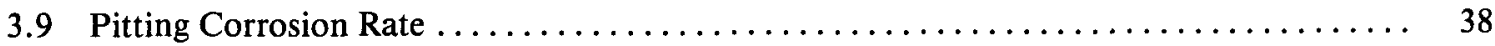

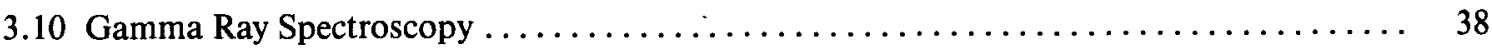

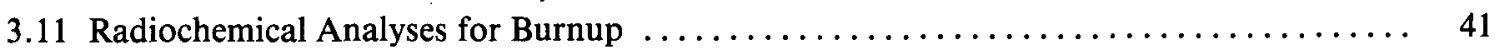

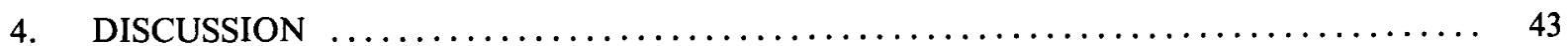

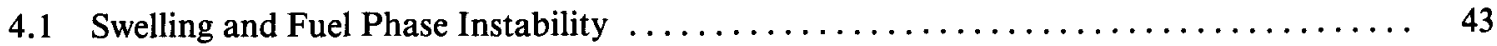

4.2 Fuel Core Integrity and Bubble Formation $\ldots \ldots \ldots \ldots \ldots \ldots \ldots \ldots \ldots \ldots \ldots \ldots \ldots \ldots$

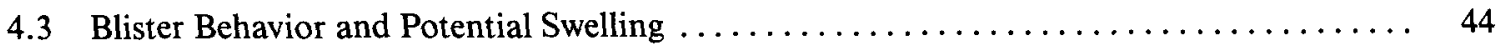

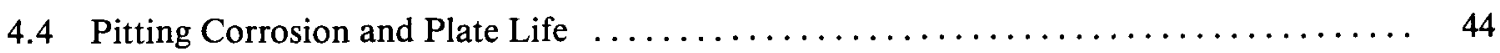

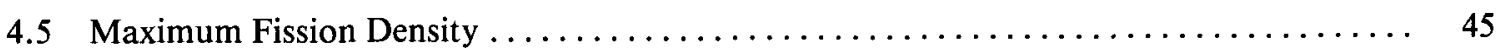




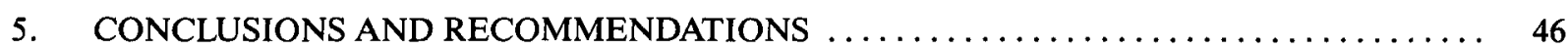

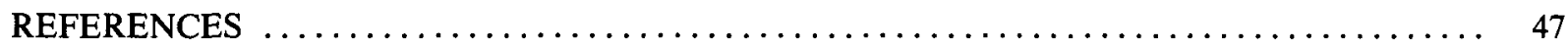

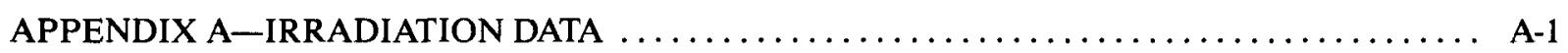

APPENDIX B-CORE AND PLATE DATA $\ldots \ldots \ldots \ldots \ldots \ldots \ldots \ldots \ldots \ldots \ldots \ldots \ldots \ldots \ldots \ldots \ldots$

FIGURES

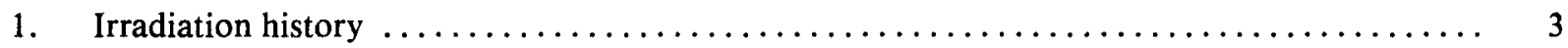

2. Typical surface appearance of the irradiated plates before and after oxide removal $\ldots \ldots \ldots .5$

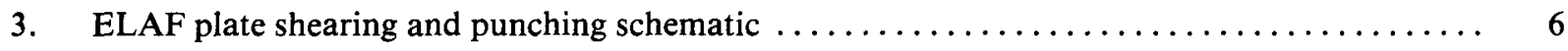

4. Core swelling versus burnup from immersion density $\ldots \ldots \ldots \ldots \ldots \ldots \ldots \ldots \ldots \ldots$

5. Core swelling versus burnup from thickness measurements $\ldots \ldots \ldots \ldots \ldots \ldots \ldots \ldots \ldots$

6. Plate and core thickness before and after irradiation $\ldots \ldots \ldots \ldots \ldots \ldots \ldots \ldots \ldots \ldots \ldots \ldots \ldots$

7. Microstructure of core and cladding of 50 vol $\% \operatorname{UAl}_{x} \ldots \ldots \ldots \ldots \ldots \ldots \ldots \ldots \ldots$

8. Microstructure of 45 vol $\%$ and of 40 vol $\% \mathrm{UAl}_{2} \ldots \ldots \ldots \ldots \ldots \ldots \ldots \ldots \ldots \ldots \ldots$

9. Fuel grains of $\mathrm{UAl}_{\mathrm{X}}$ in aluminum matrix. $\mathrm{UAl}_{2}, \mathrm{UAl}_{3}$ and $\mathrm{UAl}_{4}$

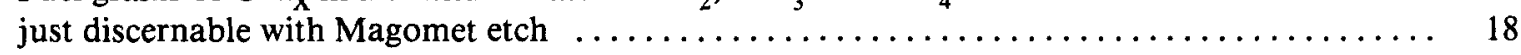

10. SEM photograph of fractured surface by secondary emission, plate $013 \ldots \ldots \ldots \ldots \ldots$

11. SEM photograph of fractured surface by secondary emission, plate $032 \ldots \ldots \ldots \ldots \ldots \ldots$

12. SEM photograph of fractured surface by back scatter emission (plate 032) identifies

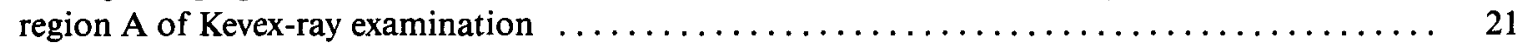

13. Examination of fuel grain $\mathrm{A}$ for $\mathrm{UAl}_{2}, \mathrm{UAl}_{3}, \mathrm{UAl}_{4}$ and $\mathrm{U} \ldots \ldots \ldots \ldots \ldots \ldots \ldots \ldots \ldots \ldots \ldots \ldots \ldots$

14. SEM photographs of plate 007 , composition 50 vol\% $\mathrm{UAl}_{\mathrm{x}} \ldots \ldots \ldots \ldots \ldots \ldots \ldots \ldots .24$

15. SEM photographs of plate 019 , composition 50 vol\% $\mathrm{UAl}_{2} \ldots \ldots \ldots \ldots \ldots \ldots \ldots$

16. SEM photographs of plate 006 , composition $50 \mathrm{vol}_{0} \mathrm{UAl}_{\mathrm{x}} \ldots \ldots \ldots \ldots \ldots \ldots \ldots \ldots \ldots$

17. SEM photographs of plate 013 , composition 50 vol $\% \mathrm{UAl}_{2} \ldots \ldots \ldots \ldots \ldots \ldots \ldots \ldots$

18. SEM photographs of plate 028 , composition 45 vol $\% \mathrm{UAl}_{2} \ldots \ldots \ldots \ldots \ldots \ldots \ldots \ldots \ldots$

19. SEM photographs of plate 030 , composition 40 vol $\% \mathrm{UAl}_{2} \ldots \ldots \ldots \ldots \ldots \ldots \ldots \ldots .29$

20. SEM photographs of plate 013 , acid etch, 50 vol $\% \mathrm{UAl}_{2} \ldots \ldots \ldots \ldots \ldots \ldots \ldots \ldots$

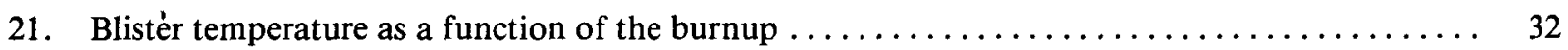


22. Photographs of blister samples from 50 vol\% $\mathrm{UAl}_{2}$ and $\mathrm{UAl}_{3} \ldots \ldots \ldots \ldots \ldots \ldots \ldots \ldots$

23. Photographs of blister samples from 45 vol $\%$ and 40 vol $\% \mathrm{UAl}_{2} \ldots \ldots \ldots \ldots \ldots \ldots \ldots$

24. Typical photographs of replica areas on oxide stripped plates $\ldots \ldots \ldots \ldots \ldots \ldots \ldots \ldots \ldots$

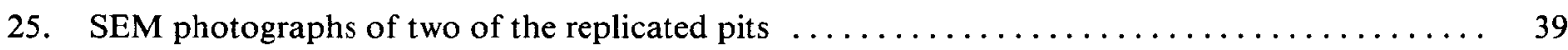

\section{TABLES}

1. Immersion density of sheared sections of irradiated plates $\ldots \ldots \ldots \ldots \ldots \ldots \ldots \ldots \ldots$

2. Calculation of preirradiated density of sheared sections $\ldots \ldots \ldots \ldots \ldots \ldots \ldots \ldots \ldots \ldots \ldots$

3. Instability of $\mathrm{UAl}_{2}$ phase during plate processing $\ldots \ldots \ldots \ldots \ldots \ldots \ldots \ldots \ldots \ldots \ldots$

4. Thickness measurements of irradiated plates $\ldots \ldots \ldots \ldots \ldots \ldots \ldots \ldots \ldots \ldots \ldots \ldots \ldots \ldots$

5. Comparison of metallurgical core thickness change with immersion density change

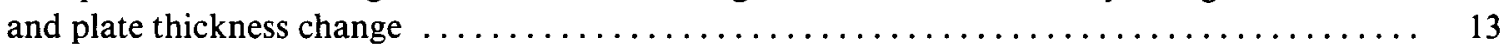

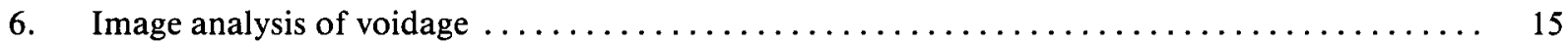

7. Comparison of core thickness change during fabrication and irradiation $\ldots \ldots \ldots \ldots \ldots \ldots$

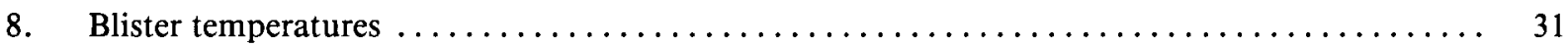

9. Measured pit depths and calculated maximum total pitting corrosion $\ldots \ldots \ldots \ldots \ldots \ldots \ldots$

10. Relative radionuclide activity of the twelve plates in counts per second for the

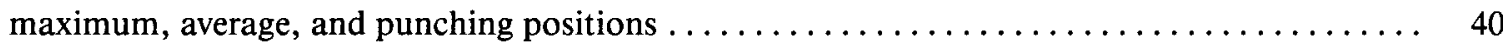

11. Ratios of isotopic maximum gamma counts per second to those of the burnup

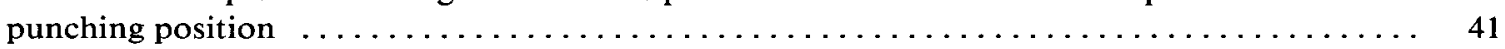

12. Mass spectral isotopic ratios for ELAF burnup samples $\ldots \ldots \ldots \ldots \ldots \ldots \ldots \ldots \ldots \ldots \ldots$

13. Burnup of ELAF fuel plates from isotopic ratios, peaking factor, and PDQ calculations .... 42 


\title{
ACRONYMS AND ABBREVIATIONS
}

\author{
AI Atomics International \\ ATR Advanced Test Reactor \\ DOE United States Department of Energy \\ ELAF Extended Life Aluminide Fuel \\ INEL Idaho National Engineering Laboratory \\ MITR Massachusetts Institute of Technology Reactor \\ MURR Missouri University Research Reactor \\ NDT Nondestructive testing \\ SEM Scanning Electron Microscopy
}




\section{EXTENDED LIFE ALUMINIDE FUEL FINAL REPORT}

\section{INTRODUCTION}

The Extended Life Aluminide Fuel (ELAF) Program $^{1,2}$ conducted by EG\&G Idaho for the Department of Energy, University of Missouri, and Massachusetts Institute of Technology had an objective of determining whether fuel loading and burnup limits for fuel elements in university research reactors could safely be increased beyond the limits presently allowed by reactor licensing restrictions. For the program, 30 fuel plates were constructed to a maximum fuel loading that could be produced on a commercial basis. These contained $\mathrm{UAl}_{2}$ and $\mathrm{UAl}_{3}$ fuel $\left(\mathrm{UAl}_{\mathrm{x}}\right.$ ) cores, with maximum boron content as used in the Advanced Test Reactor (ATR) at the Idaho National Engineering Laboratory. The maximum boron content was incorporated to reduce initial reactor reactivity. The $\mathrm{UAl}_{2}$ fuel core was used to gain higher uranium content. The test program was planned so that the fuel plates would be irradiated to a maximum fission density of $3-4 \times 10^{21} \mathrm{f} / \mathrm{cm}^{3}$ (about $50 \%$ burnup for the $50 \mathrm{vol} \%$ fuel plate cores). This burnup is more than twice that presently allowed in university reactors.

The $\mathrm{UAl}_{\mathrm{x}}$ dispersion fuel system was developed $^{3,4}$ to meet a need in the high flux, high power Advanced Test Reactor (ATR). Several features of the $\mathrm{UAI}_{\mathrm{x}}$ dispersion fuel system are reported $5,6,7,8$ to extend its performance capability in high flux reactors. The powder dispersion causes voidage to be fabricated into the fuel matrix, which may accommodate fission products. The $\mathrm{UAl}_{\mathrm{x}}$ structure has exceptional tolerance for fission gas retention, and burnable poisons can be readily dispersed in the fuel matrix.

Uranium aluminide fuel plates with lower fuel loading than the ELAF plates have been successfully irradiated to fission densities almost as high. 9,10 The ATR fuel plates containing principally $\mathrm{UAl}_{3}$, range from 40 to $60 \mathrm{wt} \% \mathrm{UAl}_{x}$, while plates described in the literature ${ }^{10}$ contain 45.5 or $54.5 \mathrm{wt} \% \mathrm{UAl}_{2}$, or $50 \mathrm{wt} \% \mathrm{UAl}_{3}$. These ELAF experimental plates contain 64 to $73.3 \mathrm{wt} \%$ $\mathrm{UAl}_{\mathrm{x}}$ - principally $\mathrm{UAl}_{2}$, or $67.4 \mathrm{wt} \% \mathrm{UAl}_{\mathrm{x}}-$ principally $\mathrm{UAl}_{3}$. This fuel loading corresponds to the presence of the brittle constituent of 40 to $50 \mathrm{vol} \%$. This introduces the question of whether the fuel core will retain a sufficiently ductile behavior during irradiation to resist blister formation. The recent rolling test program at Atomics International (AI) ${ }^{11}$ indicates current technology can be used to produce quality fuel plates on a production line basis, and the eminently good irradiation performance of the $\mathrm{UAl}_{\mathrm{x}}$ fuel in test reactors 9 and experimental plates $3,4,5,6,7,8,10$ indicates that failure should not occur in the fuel.

Preliminary reports 2,12 indicated that the principal problem would be pitting due to corrosion. 


\section{PLATE DESIGN AND IRRADIATION HISTORY}

Fuel plate dimensions were selected to fit the ATR I-hole configuration and to provide the plate area required for testing. The 12 plate configuration for a test insertion is shown in Appendix A, Figure A-1. Thickness of plates and cores, and plate construction methods were selected to match the Missouri University Research Reactor (MURR) and ATR fuel. Extrapolation of the test data to a $1.524-\mathrm{mm}(0.060$-in.) plate will provide MIT with the required supporting data for extended fuel burnup in the Massachusetts Institute of Technology Reactor (MITR).

The finished plates measure $25.4 \pm 0.127$ $\times 317.5 \pm 0.762 \times 1.27 \pm 0.025 \mathrm{~mm}(1.000$ $\pm 0.005 \times 12.50 \pm 0.030 \times 0.050 \pm 0.001$ in.). The fuel core dimensions are $\sim 20.32 \times 266.7$ x $0.508 \mathrm{~mm}(0.8 \times 10.5 \times 0.02$ in.). A $9.535-\mathrm{mm}$ (3/8-in.) hole centered in the top end of each plate provided a means for individual plate removal in the canal or hot cell.

The $\mathrm{UAI}_{\mathrm{x}}$ powder was prepared, and 30 fuel plates were fabricated by AI. The U-235 enrichment was $93.0 \pm 1.0 \%$ for all batches. Chemical analysis of the JF and $\mathrm{JJ}$ blends is given in Appen$\operatorname{dix} B$. The metal impurities were less than $0.3 \%$, with no individual impurity exceeding $600 \mathrm{ppm}$. No free metallic uranium was present in any powder samples as determined by $\mathrm{x}$-ray analysis. Other core and plate data are given in Appendix B.

Nondestructive testing (NDT) inspections for nonbond and minimum cladding thickness met the accepted criteria of the ATR Fuel Element Specification. ${ }^{13}$ Fabrication was made according to specification ES-50607A. ${ }^{14}$

\subsection{Irradiation}

Irradiation was begun in the ATR I-9 facility in July 1981, and continued in I-13 until June 1986 (Figure 1). The thermal flux in the facility varies between 3 and $7 \times 10^{13} \mathrm{n} / \mathrm{cm}^{2}$ s. The peak gamma heat in the facility of $1.55 \mathrm{~W} / \mathrm{g}$ was used with corrosion film estimates in the MACABRE computer code to calculate maximum fuel plate temperatures versus operating time. The maximum nominal and
$2 \sigma$ plate temperatures were 395 and $407 \mathrm{~K}$, respectively; these decreased with operating time.

During the irradiation period, the 30 plates were inserted in the reactor in groups of 12 . Until the end of the period, each plate was removed, as required, in order to inspect for corrosion pit depth (Figure 1). If the corrosion pit depth of any plate was estimated to be approaching $6 \mathrm{mil}$, that plate was removed and a new plate inserted for the next reactor cycles. Eleven inspection intervals were recorded. At the start of the test program, three plates failed by pitting corrosion after 172 full power days. 12

Neutron flux and burnup calculations were made with the PDQ neutron diffusion-depletion program through the irradiation history of the fuel plates. Two-dimensional XY and RZ-4 energy group PDQ problems were developed to model the tests. In the burnup calculation for each test cycle, a correction factor was applied so that the calculated thermal neutron flux matched the measured value obtained from the flux monitors, which were placed in the test and removed after each test cycle.

The extent of burnup from these calculations was used, along with the inspection for pitting, to guide the test termination for each plate and for the end of irradiation. The goal of the program was to reach a maximum burnup of $3.3 \times 10^{21} \mathrm{f} / \mathrm{cm}^{3}$. Because of peaking, expected at the sides and top or bottom of the plates, the calculated peak burnup before the end of irradiation was allowed to reach $4.2 \times 10^{21} \mathrm{f} / \mathrm{cm}^{3}$.

Gamma ray spectroscopy was done on 12 plates selected according to the maximum burnup for that composition group. The gamma ray spectroscopy showed some peaking. The extent of the peaking on the gamma scans was limited by the size of the collimator and scanner characteristics. The results of the gamma ray scanning will be presented in Section 3.10 .

Radiochemical analysis for burnup was made on the twelve plates selected for highest burnup from the four composition groups (50 vol\% $\mathrm{UAl}_{2}$, $45 \mathrm{vol} \% \mathrm{UAl}_{2}, 40 \mathrm{vol} \% \mathrm{UAl}_{2}$, and $\left.50 \mathrm{vol} \% \mathrm{UAl}_{3}\right)$. The analysis is given in Section 3.11. 


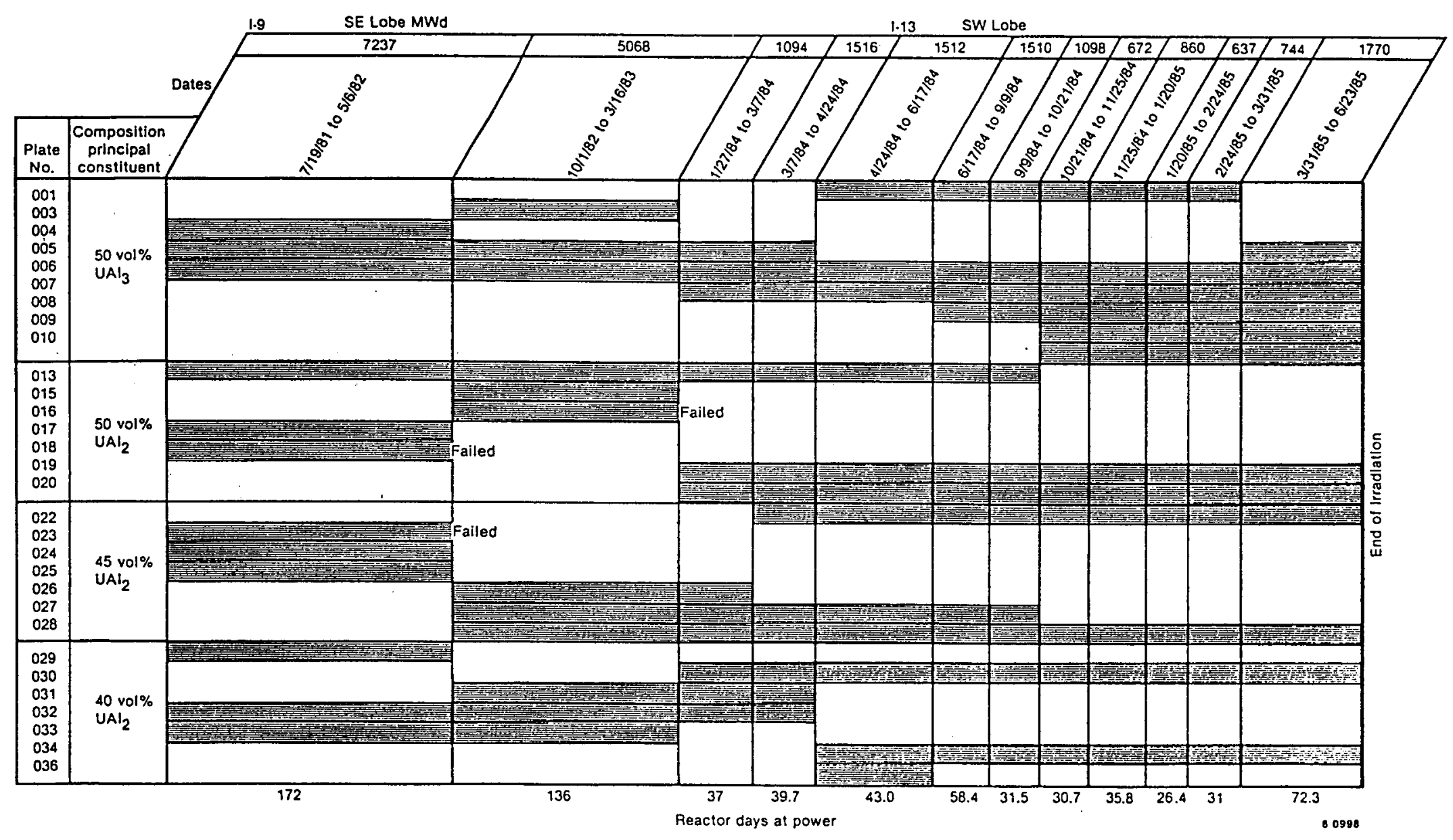

Figure 1. Irradiation history. 


\section{TEST EXAMINATIONS}

Twelve plates were removed from the reactor on June 23, 1985, and allowed a decay time to cool before the 27 plates were shipped to the hot cell for measurements. After each inspection period, those plates not reinserted in the reactor were stored in the ATR canal. The test examinations for this report included: visual examination and photography; dimensional measurements before and after oxide removal; oxide removal; immersion density; metallography; scanning electron microscopy; pit replication on fifteen plates not selected for destruct tests; gamma ray spectroscopy; and radiochemical analysis for burnup.

\subsection{Visual Examination and Photography}

Visual examination of the plates revealed small pits and corrosion spots with some scratches due to handling. Typical surface appearance of the irradiated plates, before and after oxide removal, are shown in Figure 2. A deep pit in the side of plate No. 004 is shown in Figure 2(c). The depth of this pit will be presented in Section 3.9. No blistering or oxide spalling was seen. The oxide thickness will be discussed in Section 3.3.

Corrosion and pitting behavior is discussed in Section 3.9.

\subsection{Oxide Removal}

Oxide thickness was measured by eddy current technique on 12 plates in July 1982 . Additional plates were measured on December 20,1984, and at the end of the irradiation on June 26,1985 . The oxide thickness increased with time in the reactor, as expected. Only normal oxide thickness occurred. The values are given in Section 3.4.1. In the hot cell, after the thickness of the plates was measured with a micrometer, the oxide was removed and the plate thickness remeasured.

Oxide removal from the plates in the hot cell was accomplished in a solution of $20 \mathrm{~g}$ of chromic acid $\left(\mathrm{CrO}_{3}\right)$ and $35 \mathrm{ml}$ of $85 \%$ phosphoric acid in one liter of distilled water. The plates were held in a holding rack and stripped in the boiling solution until the oxide was gone (about 10 minutes).

\subsection{Dimensional Measurements}

Thickness measurements were made in the canal, using a dial indicator, and in the hot cell, using a micrometer. The thickness measurements in the hot cell were made before and after removal of the oxide. The results are presented in Section 3.4.1.

\subsection{Immersion Density and Swelling}

The immersion density of the samples $(2 \times 3 / 4$ in. sections) sheared from the core region from each of the twelve plates (Figure 3 ) was done by the method described in ASTM B 311 (1979). The density (D) was calculated from the formula:

$\mathrm{D}=\frac{\mathrm{AE}}{\mathrm{A}-\mathrm{B}}$

where

$$
\begin{aligned}
\mathrm{A} \quad= & \text { weight of specimen in air }(\mathrm{g}) \\
\mathrm{B} \quad= & \text { weight of specimen in water }(\mathrm{g}) \\
\mathrm{E} \quad= & \begin{array}{l}
\text { density of water in } \mathrm{g} / \mathrm{cm}^{3}\left(20^{\circ} \mathrm{C}\right. \text { for } \\
\text { all samples }) .
\end{array}
\end{aligned}
$$

The dry and wet weights, and the immersion density calculated by the formula, are given in Table 1 . The preirradiated density for the sheared sections was calculated from the core and plate specifications for all fabricated plates from Table B-1. ${ }^{\mathrm{a}}$ The calculated, preirradiated, sheared plate density of the sections was obtained by using the deburred core compact weight, the core volume from the void volume measurements, and other data as given in Table 2. The plate core thickness can then be calculated from these values, and the core surface area obtained from radiographic fuel core measurements of the plate. ${ }^{15}$ The calculated, preirradiated, sheared plate density and the plate core thickness are given in Table 2. It is noted that the plate core thickness obtained is less than the average metallographic core thickness for the sample from each composition group. Since the production plates have been hot rolled and blister annealed, relative

a. Appendix B. 




(a) Plate 016 before oxide removal

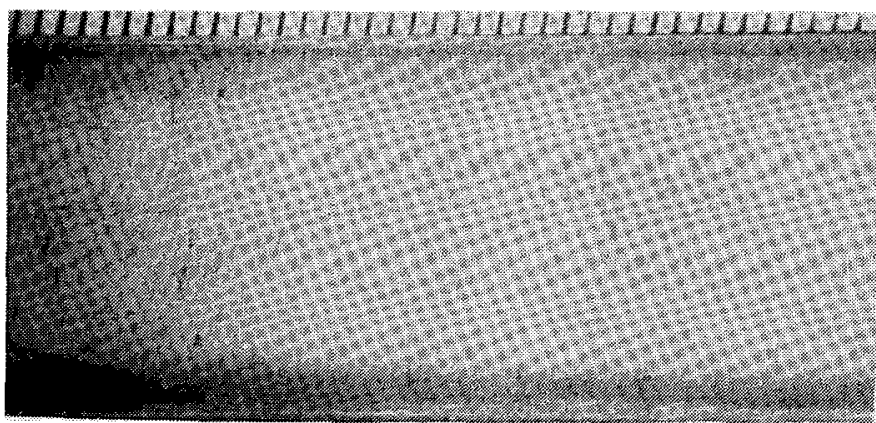

(b) Plate 016 before oxide removal

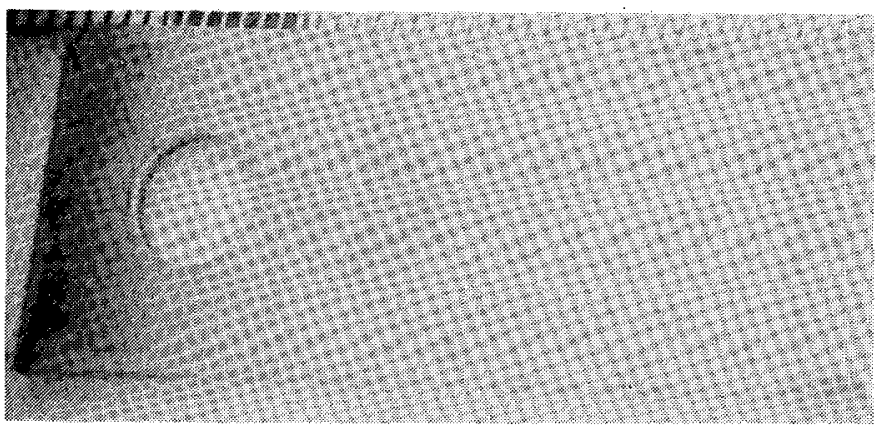

(d) Plate 018 after oxide removal

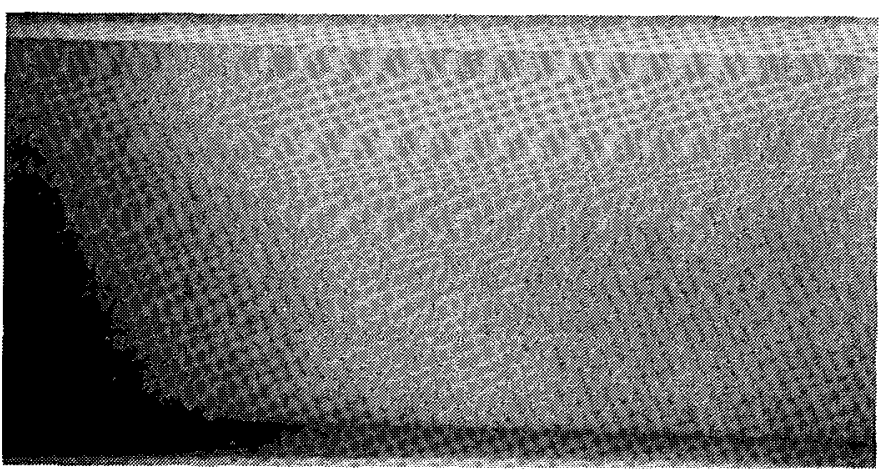

(e) Plate 016 after oxide removal

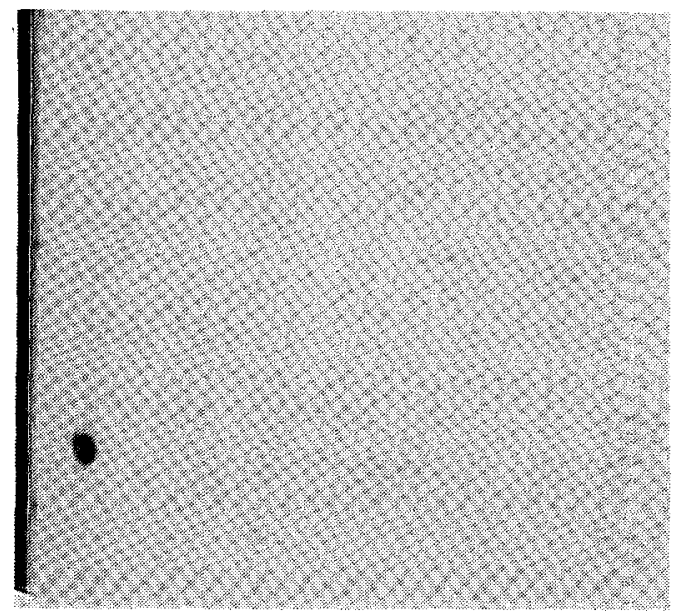

(c) Plate 004 before oxide removal with deep pit on side of plate

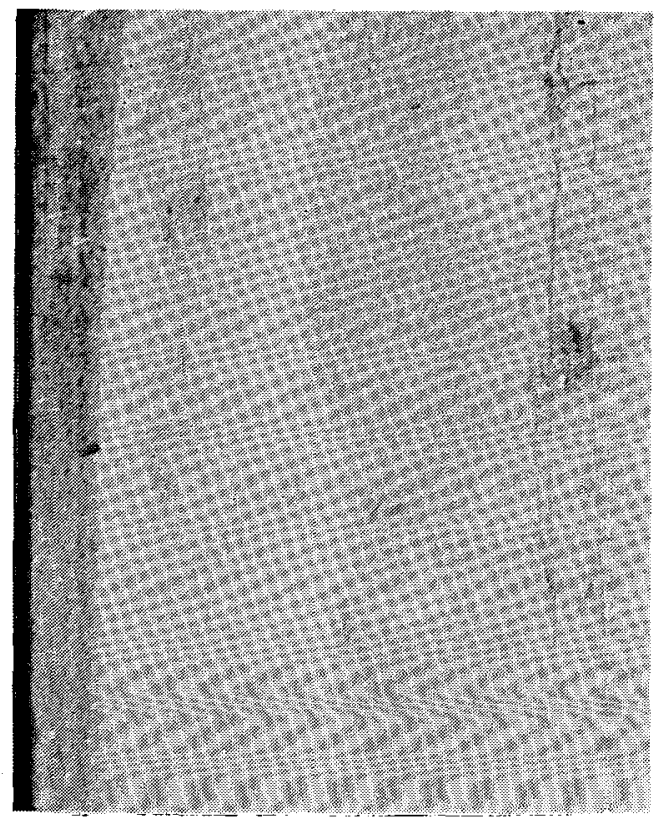

(f) Plate 013 after oxide removal

Figure 2. Typical surface appearance of the irradiated plates before and after oxide removal. 


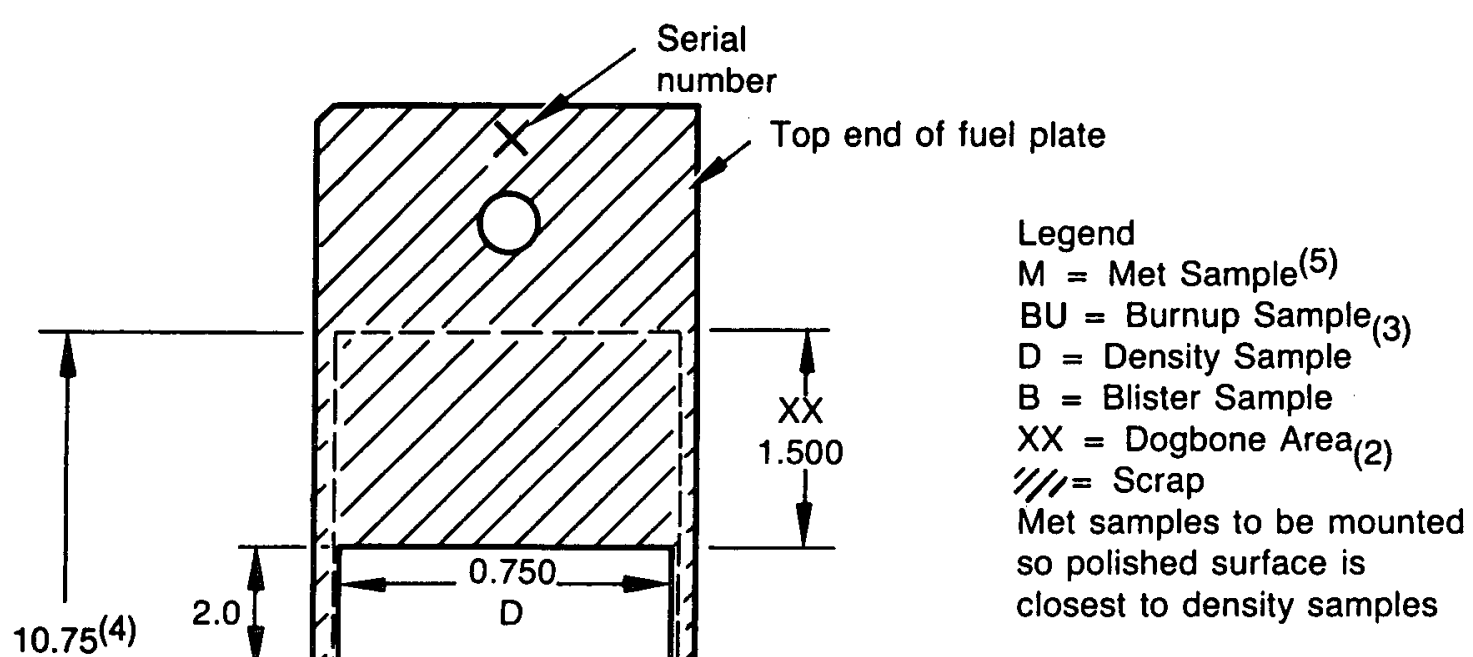

Legend

BU $=$ Burnup Sample $_{(3)}$

$D=$ Density Sample

$B=$ Blister Sample

$X X=$ Dogbone Area $_{(2)}$

$/ / /=$ Scrap

Met samples to be mounted

so polished surface is

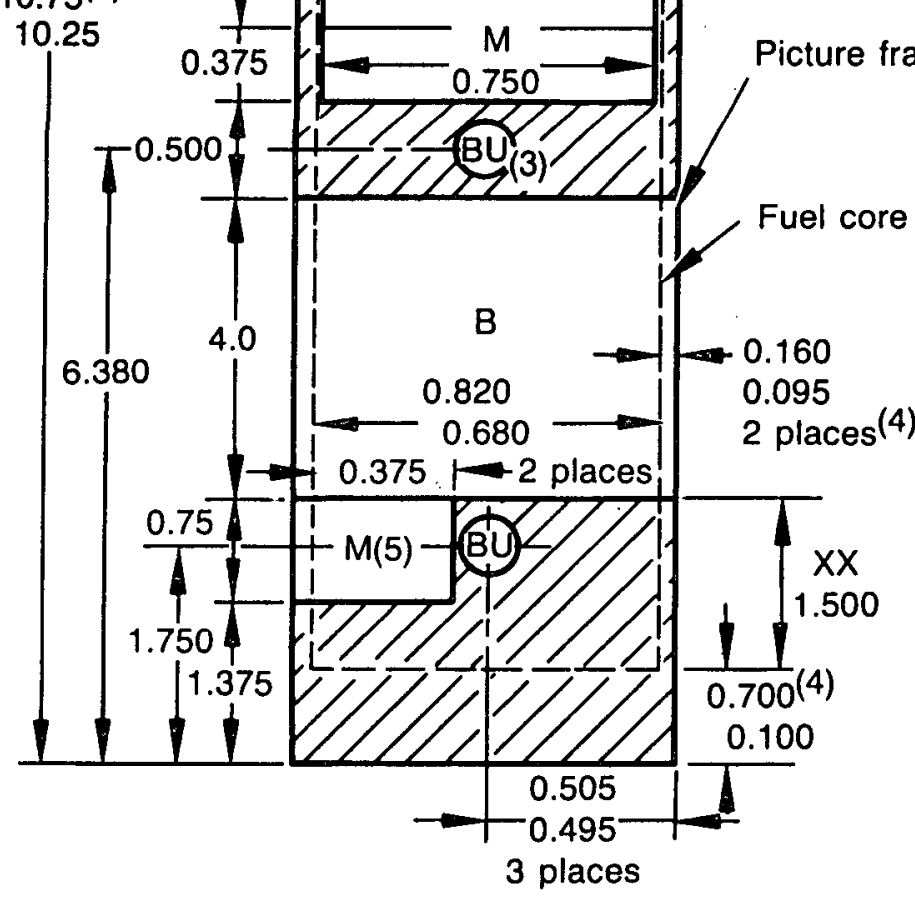

(1) Region of the fuel core within one and one-half inches from its ends, where thickening can occur during the rolling process.

(2) The window-shaped aluminum frame which hold the fuel core.

(3) Burnup samples to be punched on axial and transverse center lines as shown.

(4) Reference demension only.

(5) Bottom met sample to be punched as close to BU samples as possible.

Scale: None

Dimensions in inches

Figure 3. ELAF plate shearing and punching schematic. 
Table 1. Immersion density of sheared sections of irradiated plates

\begin{tabular}{|c|c|c|c|c|c|c|c|}
\hline $\begin{array}{c}\text { Plate } \\
\text { Number }\end{array}$ & $\begin{array}{c}\text { Dry } \\
\text { Weight } \\
\text { (g) } \\
\end{array}$ & $\begin{array}{l}\text { Wet } \\
\text { Weight } \\
\text { (g) } \\
\end{array}$ & $\begin{array}{c}\text { Measured } \\
\text { Density } \\
\left(\mathrm{g} / \mathrm{cm}^{3}\right) \\
\end{array}$ & $\begin{array}{c}\text { Preirradiated } \\
\text { Calculated } \\
\text { Section Density } \\
\left(\mathrm{g} / \mathrm{cm}^{3}\right) \\
\end{array}$ & $\begin{array}{c}\text { Density } \\
\text { Decrease } \\
(\%) \\
\end{array}$ & $\begin{array}{c}\text { CSAP PDQ } \\
\text { Average Burnup } \\
\left(\mathrm{x} 10^{-21} \mathrm{f} / \mathrm{cm}^{3}\right) \\
\end{array}$ & $\begin{array}{l}\text { Punch } \\
\text { Fission } \\
\text { Density }\end{array}$ \\
\hline 005 & 3.7845 & 2.6299 & 3.2718 & 3.3320 & 1.81 & 1.80 & 1.28 \\
\hline 006 & 3.1313 & 2.1680 & 3.2447 & 3.3462 & 3.03 & 2.30 & 1.73 \\
\hline 007 & 4.1006 & 2.8521 & 3.2785 & 3.3297 & 1.54 & 1.48 & 1.06 \\
\hline 013 & 4.2433 & 3.0061 & 3.4236 & 3.5992 & 4.88 & 2.98 & 2.02 \\
\hline 019 & 4.2186 & 3.0141 & 3.4961 & 3.6100 & 3.16 & 2.13 & 1.49 \\
\hline 020 & 4.1226 & 2.9312 & 3.4541 & 3.5768 & 3.43 & 2.24 & 1.72 \\
\hline 022 & 4.0864 & 2.8989 & 3.4350 & 3.5251 & 2.56 & 1.82 & 1.22 \\
\hline 027 & 4.2564 & 3.0223 & 3.4428 & 3.5081 & 1.86 & 1.94 & 1.36 \\
\hline 028 & 3.9421 & 2.7715 & 3.3615 & 3.5120 & 4.29 & 2.61 & 1.96 \\
\hline 030 & 3.8557 & 2.6951 & 3.3162 & 3.4097 & 2.74 & 2.25 & 1.52 \\
\hline 032 & 4.2891 & 2.9967 & 3.3127 & 3.4365 & 3.60 & 2.14 & 1.49 \\
\hline 033 & 3.7788 & 2.6481 & 3.3360 & 3.4224 & 2.52 & 2.00 & 1.42 \\
\hline
\end{tabular}

a. Calculated from the formula $\mathrm{D}=\mathrm{AE} /\left(\mathrm{A}-\mathrm{B}\right.$ ) where $\mathrm{E}$ (the density of water at a temperature of $20^{\circ} \mathrm{C}$ ) was taken as $0.9982 \mathrm{~g} / \mathrm{cm}^{3}$.

b. Table 13 plus $10 \%$. The low punch fission density plus $10 \%$ gives an average fission density equivalent to the CSAP PDQ average (see Section 3.11).

amounts of the aluminide phases $\mathrm{UAl}_{2}, \mathrm{UAl}_{3}$ and $\mathrm{UAl}_{4}$ have changed (there is less $\mathrm{UAl}_{2}$ and more $\mathrm{UAl}_{4}$ than in the fuel powder charge), Table 3 . The stability of the $\mathrm{UAl}_{2}$ phase in compact $1 \mathrm{JF} 038 \mathrm{YD}$ was investigated by taking pieces of the compact and giving each piece the heat treatment indicated (Table 3). The analyses of the pieces were done by $\mathrm{X}$-ray, similar to the powder blend JF. The as compacted values for $\mathrm{UAl}_{2}, \mathrm{UAl}_{3}$, and $\mathrm{UAl}_{4}$ (Table 3 ) of 71,28 , and 1 , are to be compared with those of the powder blend $\mathrm{JF}$ values for $\mathrm{UAl}_{2}, \mathrm{UAl}_{3}, \mathrm{UAl}_{4}$, respectively, of 67,33 , and $<1$, with $U$ alloy not detected. The calculated core thickness from the core compact weight and volume is lower than the metallurgical sample for each group by 4 to $10 \%$ (Table 2). This difference in the core thickness is attributed to the lack of stability of the $\mathrm{UAl}_{2}$ phase during plate processing and the consequent growth of the core thickness. The calculated preirradiated sheared plate density is dependent upon the relative core and clad thickness. This density is given in Table 2 for the metallurgical core thickness of the metallurgical sample plates, as well as for the calculated core thickness. The calculated density from the computed core thickness is lower than that calculated from the metallurgical samples by 1 to $3 \%$. Since the calculated preirradiated density from the metallurgical sample core thickness gives a higher swelling value, these are the values used in computing the swelling in Table 1.

The swelling (density decrease) from the immersion density measurements is plotted in Figure 4 for the burnupa of each plate. It is noted that the immersion density of the sheared section also gives an average measurement (peaking is seen in the thickness measurements). A linear least squares analysis for the $P Q^{b}$ fission density (Table 1) gives an equation

a. The burnup was taken from the nuclear calculations. It is approximately the same as that measured for the burnup punching times the peaking factor, and is the burnup value used for all the figures and text except as otherwise noted (especially Sections 3.11 and 4).

b. A two dimensional neutronics diffusion code. 
Table 2. Calculation of preirradiated density of sheared sections

\begin{tabular}{|c|c|c|c|c|c|c|c|c|c|c|c|c|c|c|c|c|c|c|}
\hline $\begin{array}{c}\begin{array}{c}\text { Plate } \\
\text { Number }\end{array} \\
\end{array}$ & $\begin{array}{c}\text { Deburred } \\
\text { Core } \\
\text { Compact } \\
\text { Weight } \\
\text { (g) } \\
\end{array}$ & & $\begin{array}{l}\text { Core }^{\mathrm{a}} \\
\text { Volume } \\
\mathrm{v}_{\mathrm{c}} \\
\left(\mathrm{cm}^{3}\right) \\
\end{array}$ & $\begin{array}{l}\text { Core } \\
\text { Compact } \\
\text { Density } \\
{\mathrm{g} / \mathrm{cm}^{3}}^{3} \\
\end{array}$ & $\begin{array}{l}\text { Radiographi } \\
\text { Surface Area } \\
\quad\left(\mathrm{cm}^{2}\right) \\
\end{array}$ & & $\begin{array}{c}\text { Core } \\
\text { Thickness } \\
\text { (cm) } \\
\end{array}$ & $\begin{array}{c}\text { Core } \\
U \\
\text { Weight } \\
(\mathrm{cm}) \\
\end{array}$ & $\begin{array}{c}\mathrm{U} \\
\text { Density } \\
\mathrm{g} / \mathrm{cm} \\
\text { Core } \\
\end{array}$ & $\begin{array}{c}\mathrm{U} \\
\text { Atom } \\
\text { Density } \\
\mathrm{a} / \mathrm{cm}^{3} \\
\text { Core } \\
\times 10^{-21} \\
\end{array}$ & $\begin{array}{c}\text { Preirradiated } \\
\text { Plate } \\
\text { Thickness } \\
\text { (cm) } \\
\end{array}$ & $\begin{array}{c}\text { Clad } \\
\text { Thickness } \\
\text { (cm) } \\
\end{array}$ & $\begin{array}{c}\text { Core }^{\mathrm{c}} \\
\text { Weight } \\
\text { per } \\
\mathrm{cm}^{2} \\
\end{array}$ & $\begin{array}{c}\mathrm{Clad}^{\mathrm{d}} \\
\text { Weight } \\
\text { per } \\
\mathrm{cm}^{2} \\
\end{array}$ & $\begin{array}{c}\text { Section } \\
\text { Weight } \\
\text { per } \\
\mathrm{cm}^{2} \\
\end{array}$ & $\begin{array}{c}\text { Preirradiated }^{\mathrm{e}} \\
\text { Calculated } \\
\text { Density } \\
\left(\mathrm{g} / \mathrm{cm}^{3}\right) \\
\end{array}$ & $\begin{array}{c}\text { Metallurgical } \\
\text { Core } \\
\text { Thickness } \\
\text { For Group } \\
\text { (cm) } \\
\end{array}$ & $\begin{array}{c}\text { Preirradiated }^{\mathrm{g}} \\
\text { Calculated }^{\text {Density }} \\
\left(\mathrm{g} / \mathrm{cm}^{3}\right) \\
\end{array}$ \\
\hline 005 & 11.94 & & 2.908 & 4.106 & 53.828 & & 0.0540 & 5.73 & 1.97 & 5.04 & 0.1295 & 0.0755 & 0.222 & 0.205 & 0.427 & 3.295 & 0.0574 & 3.3320 \\
\hline 006 & 11.95 & & 2.883 & 4.145 & 53.618 & & 0.0538 & 5.73 . & 1.99 & 5.09 & 0.1300 & 0.0762 & 0.223 & 0.207 & 0.430 & 3.307 & 0.0574 & 3.3462 \\
\hline \multirow[t]{2}{*}{007} & 11.95 & & 2.912 & 4.104 & 53.465 & & 0.0545 & 5.73 & 1.97 & 5.04 & 0.1298 & 0.0753 & 0.224 & 0.204 & 0.428 & 3.298 & 0.0574 & 3.3297 \\
\hline & & Ave & 2.901 & Av & 53.637 & Ave & 0.0541 & $\mathrm{Av}$ & e 1.98 & & & & & & & & & \\
\hline 013 & 13.70 & & 2.998 & 4.570 & 54.230 & & 0.0553 & 7.93 & 2.65 & 6.78 & 0.1295 & 0.0742 & 0.253 & 0.202 & 0.455 & 3.507 & 0.0617 & 3.5992 \\
\hline 019 & 13.68 & & 2.956 & 4.628 & 53.996 & & 0.0547 & 7.92 & 2.68 & 6.86 & 0.1318 & 0.0771 & 0.253 & 0.209 & 0.462 & 3.508 & 0.0617 & 3.6100 \\
\hline \multirow[t]{2}{*}{020} & 13.69 & & 3.002 & 4.560 & 53.946 & & 0.0556 & 7.92 & 2.64 & 6.77 & 0.1321 & 0.0765 & 0.254 & 0.208 & 0.462 & 3.492 & 0.0617 & 3.5768 \\
\hline & & Ave & 2.985 & Av & 54.057 & Ave & 0.0552 & $\mathrm{Av}$ & e 2.66 & & & & & & & & & \\
\hline 022 & 13.01 & & 2.860 & 4.550 & 53.159 & & 0.0538 & 7.12 & 2.49 & 6.37 & 0.1295 & 0.0757 & 0.245 & 0.206 & 0.451 & 3.476 & 0.0572 & 3.5251 \\
\hline 027 & 13.03 & & 2.891 & 4.507 & 53.593 & & 0.0539 & 7.13 & 2.47 & 6.32 & 0.1293 & 0.0754 & 0.243 & 0.205 & 0.448 & 3.462 & 0.0572 & 3.5081 \\
\hline \multirow[t]{2}{*}{028} & 13.00 & & 2.877 & 4.519 & 53.543 & & 0.0537 & 7.12 & 2.47 & 6.32 & 0.1295 & 0.0758 & 0.243 & 0.206 & 0.449 & 3.476 & 0.0572 & 3.5120 \\
\hline & & Ave & 2.876 & Av & 53.432 & Ave & 0.0538 & Av & e 2.48 & & & & & & & & & \\
\hline 030 & 12.51 & & 2.877 & 4.348 & 53.090 & & 0.0542 & 6.32 & 2.20 & 5.63 & 0.1318 & 0.0776 & 0.236 & 0.211 & 0.447 & 3.387 & 0.0561 & 3.4097 \\
\hline 032 & 12.51 & & 2.845 & 4.397 & 53.055 & & 0.0536 & 6.32 & 2.22 & 5.68 & 0.1308 & 0.0772 & 0.236 & 0.210 & 0.446 & 3.404 & $0.056 i$ & 3.4365 \\
\hline \multirow[t]{2}{*}{033} & 12.50 & & 2.875 & 4.348 & 53.593 & & 0.0536 & 6.32 & 2.20 & 5.63 & 0.1295 & 0.0759 & 0.233 & 0.206 & 0.439 & 3.391 & 0.0561 & 3.4224 \\
\hline & & Ave & 2.866 & Av & 53.246 & Ave & 0.0538 & Av & 2.21 & & & & & & & & & \\
\hline \multicolumn{19}{|c|}{ a. Core volume is calculated from core and plate data, Appendix B. } \\
\hline \multicolumn{19}{|c|}{ b. Core thickness equals core volume divided by radiographic surface area. } \\
\hline \multicolumn{19}{|c|}{ c. Core weight per $\mathrm{cm}^{2}$ equals core thickness times core compact density. } \\
\hline \multicolumn{19}{|c|}{ d. Clad weight per $\mathrm{cm}^{2}$ equals clad thickness times Al 6061 density $\left(2.715 \mathrm{~g} / \mathrm{cm}^{3}\right)$. } \\
\hline \multicolumn{19}{|c|}{ e. Preirradiated calculated density equals section weight per $\mathrm{cm}^{2}$ divided by plate thickness $(\mathrm{cm})$. } \\
\hline \multicolumn{19}{|c|}{ f. Metallurgical core thickness for group is given in Reference 5, Table 32.} \\
\hline g. Preirrz & ted calo & 1 & density & $\mathrm{n}$ metallur & gical core thick & kness. & & & & & & & & & & & & \\
\hline
\end{tabular}


Table 3. Instability of $\mathrm{UAl}_{\mathbf{2}}$ phase during plate processing

\begin{tabular}{|c|c|c|c|c|}
\hline \multirow{2}{*}{$\begin{array}{c}\text { Sample } \\
\text { Number } \\
\end{array}$} & \multirow[b]{2}{*}{ Heat Treatment } & \multicolumn{3}{|c|}{$\begin{array}{l}\text { Relative Amounts of } \\
\text { Aluminide Phase }\end{array}$} \\
\hline & & $\underline{\mathrm{UAl}_{2}}$ & $\mathrm{UAl}_{3}$ & $\mathrm{UAl}_{4}$ \\
\hline $038 \mathrm{I}$ & As compacted & 71 & 28 & 1 \\
\hline 038II & Outgassing cycle $\left(500^{\circ} \mathrm{F}, 5 \mathrm{hr}\right)$ & 74 & 25 & 1 \\
\hline 038III & $\begin{array}{l}\text { Outgassing plus hot rolling } \\
\left(910^{\circ} \mathrm{F}, 2 \mathrm{hr}\right)\end{array}$ & 35 & 60 & 5 \\
\hline 038III-1 & $\begin{array}{l}\text { Outgassing plus hot rolling plus } \\
\text { blister anneal }\left(925^{\circ} \mathrm{F}, 1 \mathrm{hr}\right)\end{array}$ & 20 & 75 & 5 \\
\hline $\begin{array}{l}\text { Typical ATR } \\
\text { Powder Blend }\end{array}$ & Before compacting or heat treatment & 8 & 68 & 24 \\
\hline
\end{tabular}

$\frac{\Delta V}{V} \%=-2.13+2.37(B)$

with correlation coefficient, $r$, of 0.93 , where $B$ is the burnup in units of $10^{21} \mathrm{f} / \mathrm{cm}^{3}$. The regression analysis for the punch fission density plus $10 \%$ (Table 1) is

The correlation coefficients, $r$, of 0.93 or 0.91 indicate that the data from all the plates fit the equations very well. The relationship indicates an induction period for swelling equivalent to a fission density of about $1 \times 10^{21} \mathrm{f} / \mathrm{cm}^{3}$. After this induction period, the slope of the equation of 2.37 , $\frac{\Delta \mathrm{V}}{\mathrm{V}} \%=-1.82+3.14(\mathrm{~B})$ or 3.14 , corresponds to a value of 2.6 noted by other investigators 9,10 for low temperature-low where $r=0.91$. burnup fuel plates. The slope corresponds to a low

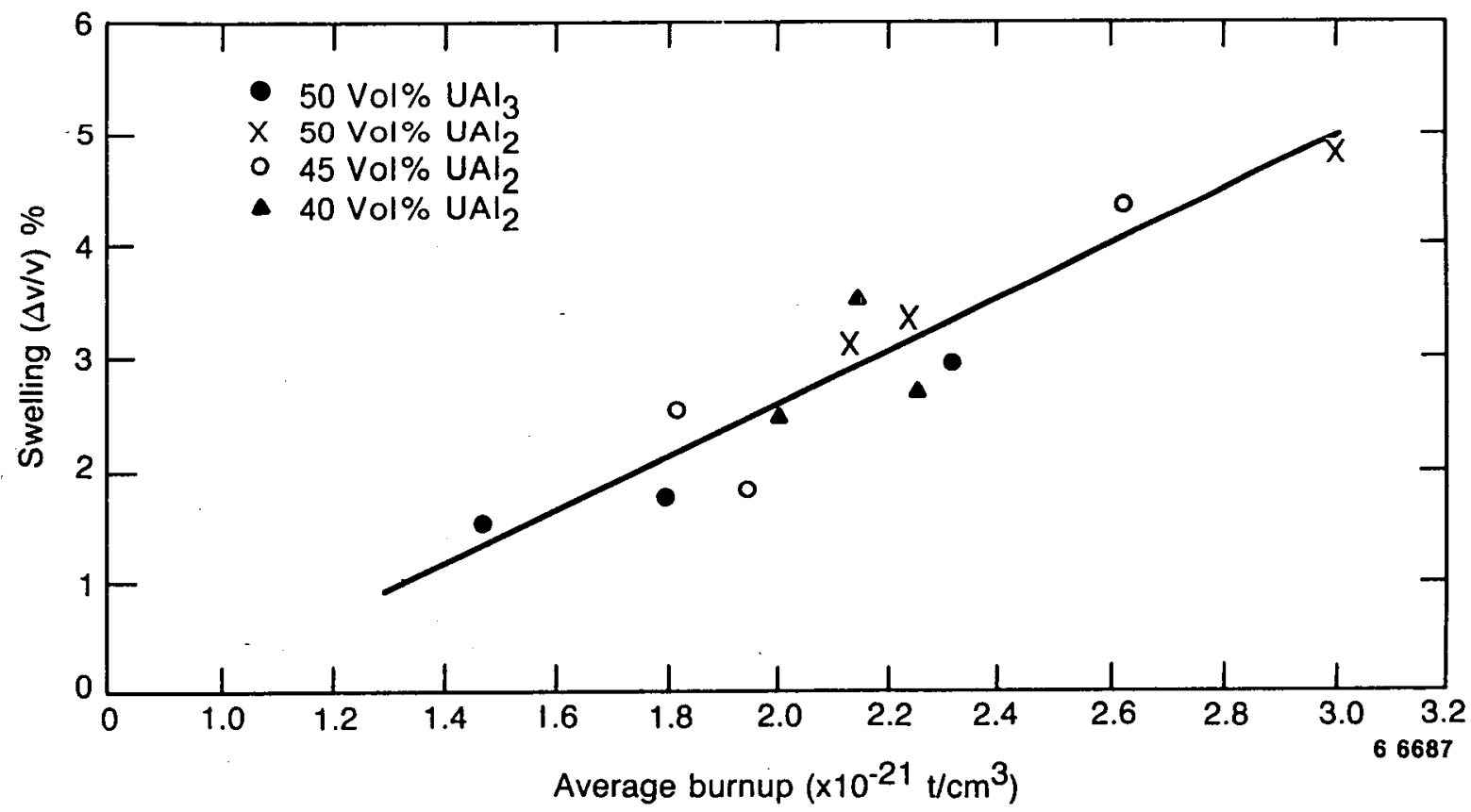

Figure 4. Core swelling versus burnup from immersion density. 
relative atomic volume increase for the fission fragments (transmutation products).

\subsubsection{Swelling Determined from Thickness} Measurements. The measurement of plate thickness was made in both the hot cell and in the canal (in the hot cell before and after oxide stripping, and in the canal before oxide stripping). In the canal, the oxide thickness was measured by eddy current technique. In the hot cell, the thickness measurements were made with a micrometer. In the canal, the thickness measurements were made with a dial gage mounted on a fixture. Because of variability in the measurements, the thickness measurements were taken to be less accurate than the hot cell measurements. The width of the plates after irradiation was measured in the hot cell and in the canal. Within the accuracy of the measuring technique, no increase in width was detected. Most of the plates had a width less than the original width of 1.005 to 1.008 in. This decrease in width was attributed to corrosion and to sliding the plates in and out of the irradiation fixture for inspection (which was conducted 11 times during the irradiation). From the lack of a width increase, it is postulated that practically all the swelling increase occurs in the thickness direction. The thickness was measured for all plates (except plate 013) in 15 places (5 along the length and 3 on the width) and in one reference position (at the top of the plate) before and after oxide stripping. For plate 013, the thickness was measured in 10 places and averaged. However, on the high side of the plate, the results are averaged separately and a high spot is also given (Table 4). In other plates, peaking in thickness was less than $4 \%$.

The hot cell plate thickness measurements, as well as some canal plate oxide thickness measurements by eddy current, are given in Table 4 . The eddy current thickness measurements and the canal plate thickness measurements tended to be slightly larger than the hot cell measurements. The plate thickness measurements in the canal were assumed to be not as accurate because of the variance of the measurements. Hence, only the hot cell plate thickness measurements are given in Table 4. The lower oxide thickness in the hot cell is presumably due to loss of water of hydration. The plate thickness measurements in the hot cell were only accurate to $0.001 \mathrm{~cm}$, as indicated in the column for the reference (position above the fuel) plate thickness. However, the fourth place accuracy indicated in the original plate thickness measurements is doubtful for some of the plates, so that the reference plate thickness instead of the original plate thickness was used for the core swelling $(\Delta t / t)$ calculation for these plates, as indicated in Table 4 . The core swelling is calculated from the difference in plate thickness $(\Delta t)$ divided by the core thickness $(t)$ taken for the composition group.

The micrometer measurements showed a peaking in swelling along one side of plate 013 , which was related to the burnup. This peaking also can be seen in the gamma scan results of this plate (Section 3.10). This peaking was looked for in the measurements of other plates. Micrometer measurements were taken along each side and down the middle of each plate; however, because of the position of the micrometer on the plate, measurements were less than $0.002 \mathrm{~cm}$ and not tabulated. For plate 013, peaking amounted to a $0.003 \mathrm{~cm}$ difference from the average of 10 measurements (as indicated for the high side and high spot, Table 4). Since $0.001 \mathrm{~cm}$ is the limit of sensitivity of the micrometer, the fourth place given in Table 4 for the measurements is a mathematical convenience.

The core swelling (except for the high side of plate 013) was plotted in Figure 5 versus the PDQ average burnup, and examined by linear least squares fitting curves. When two points that appear to have too high a swelling in comparison with burnup (due to inaccuracy in the measurement) are eliminated (plates 001 and 010), the swelling for the remaining 25 plates can be represented by the equation

$\frac{\Delta \mathrm{t}}{\mathrm{t}} \%=0.25+2.38(\mathrm{~B})$

where $B$ is the average burnup in units of $10^{21} \mathrm{f} / \mathrm{cm}^{3}$. The correlation coefficient, $\mathrm{r}$, of 0.92 indicates a good fit of all the data, so that the swelling of plates in the four groups appear to be similar. Examination by regression analysis of the punch fission density gives

$\frac{\Delta \mathrm{t}}{\mathrm{t}} \%=0.33+3.35(\mathrm{~B})$

with $r=0.86$, a correlation coefficient that is not as good.

3.42 Core Thickness Change by Metallography. The core thickness of the metallography samples at $50 \mathrm{X}$ was measured in at least 10 places, at fixed intervals, and averaged. The core thickness change was then calculated using the core thickness calculated in Table 2 . The average thickness 
Table 4. Thickness measurements of irradiated plates

\begin{tabular}{|c|c|c|c|c|c|c|c|c|c|c|c|}
\hline $\begin{array}{c}\begin{array}{c}\text { Plate } \\
\text { Number }\end{array} \\
\end{array}$ & $\begin{array}{l}\text { Original } \\
\text { Plate } \\
\text { Thickness } \\
\text { (cm) } \\
\end{array}$ & $\begin{array}{l}\text { Reference } \\
\text { Plate } \\
\text { Thickness } \\
\text { (cm) } \\
\end{array}$ & $\begin{array}{c}\text { Before } \\
\text { Oxide } \\
\text { Stripping } \\
(\mathrm{cm}) \\
\end{array}$ & $\begin{array}{c}\text { After } \\
\text { Oxide } \\
\text { Stripping } \\
\text { (cm) } \\
\end{array}$ & $\begin{array}{c}\text { Sum Oxide } \\
\text { Thickness } \\
\text { Both Sides } \\
\text { (mm) } \\
\end{array}$ & $\begin{array}{c}\text { Core }^{\mathrm{a}} \\
\text { Thickness } \\
\text { Change } \\
\Delta \mathrm{t} / \mathrm{t} \\
(\%) \\
\end{array}$ & $\begin{array}{c}\text { CSAP } \\
\text { PDQ } \\
\text { Average } \\
\text { Burnup } \\
\left(\mathrm{f} / \mathrm{cm} 3 \times 10^{-21}\right) \\
\end{array}$ & $\begin{array}{c}\begin{array}{c}\text { Ratio } \\
\text { Swelling } \\
\text { to Burnup }\end{array} \\
\end{array}$ & $\begin{array}{l}\text { Canal Oxide } \\
\text { Thickness } \\
\text { Measurements } \\
\text { Both Sides } \\
\text { (mm) } \\
\end{array}$ & $\begin{array}{l}\text { Punch }^{\text {b }} \\
\text { Fission } \\
\text { Density }\end{array}$ & $\begin{array}{l}\text { Ratio } \\
\text { Swelling } \\
\text { to Fission } \\
\text { Density } \\
\end{array}$ \\
\hline 001 & 0.1295 & 0.130 & 0.1332 & 0.1322 & 0.010 & 4.1 & 1.03 & 4.0 & - & - & - \\
\hline 003 & 0.1295 & 0.131 & 0.1325 & 0.1321 & 0.004 & 2.0 & 0.69 & 2.9 & - & - & - \\
\hline 004 & 0.1300 & 0.131 & 0.1327 & 0.1325 & 0.002 & 2.8 & 0.88 & 3.2 & 0.005 & - & - \\
\hline 005 & 0.1295 & - & 0.1346 & 0.1321 & 0.005 & 4.8 & 1.80 & 2.7 & 0.016 & 1.28 & 3.8 \\
\hline 006 & 0.1300 & - & 0.1340 & 0.1329 & 0.011 & 5.4 & 2.30 & 2.3 & 0.008 & 1.73 & 3.1 \\
\hline 007 & 0.1298 & - & 0.1324 & 0.1321 & 0.003 & 4.3 & 1.48 & 2.9 & 0.008 & 1.06 & 4.1 \\
\hline 008 & 0.1298 & 0.130 & 0.1323 & 0.1319 & 0.004 & 3.5 & 1.23 & 2.8 & 0.007 & & \\
\hline 009 & 0.1306 & - & 0.1330 & 0.1321 & 0.009 & 2.8 & 0.75 & 3.7 & 0.006 & - & - \\
\hline 010 & 0.1300 & - & 0.1338 & 0.1320 & 0.018 & 3.7 & 0.77 & 4.8 & 0.007 & - & - \\
\hline 013 & 0.1295 & - & 0.1348 & 0.1341 & 0.007 & 8.4 & 2.98 & 2.8 & 0.030 & 2.02 & 4.2 \\
\hline 015 & 0.1300 & - & 0.1317 & 0.1308 & 0.009 & 1.5 & 1.00 & 1.5 & - & - & - \\
\hline 017 & 0.1298 & - & 0.1318 & 0.1313 & 0.005 & 2.7 & 1.53 & 1.8 & 0.007 & - & - \\
\hline 019 & 0.1318 & 0.130 & 0.1343 & 0.1331 & 0.012 & 5.6 & 2.13 & 2.6 & 0.010 & 1.49 & 3.8 \\
\hline 020 & 0.1321 & 0.130 & 0.1337 & 0.1332 & 0.005 & 5.8 & 2.24 & 2.6 & 0.011 & 1.72 & 3.4 \\
\hline 022 & 0.1295 & - & 0.1342 & 0.1321 & 0.021 & 4.8 & 1.82 & 2.6 & 0.010 & 1.22 & 3.9 \\
\hline 024 & 0.1303 & - & 0.1323 & 0.1318 & 0.004 & 2.8 & 1.15 & 2.4 & 0.006 & - & - \\
\hline 025 & 0.1298 & - & 0.1319 & 0.1313 & 0.006 & 2.8 & 1.15 & 2.4 & - & - & - \\
\hline 026 & 0.1300 & - & 0.1328 & 0.1317 & 0.011 & 3.1 & 1.08 & 2.9 & - & - & - \\
\hline 027 & 0.1293 & - & 0.1329 & 0.1316 & 0.013 & 4.3 & 1.94 & 2.2 & 0.023 & 1.36 & 3.2 \\
\hline 028 & 0.1295 & - & 0.1340 & 0.1330 & 0.010 & 6.5 & 2.61 & 2.5 & 0.015 & 1.96 & 3.3 \\
\hline 029 & 0.1303 & - & 0.1325 & 0.1321 & 0.004 & 3.3 & 1.04 & 3.2 & 0.005 & - & - \\
\hline 030 & 0.1318 & 0.131 & 0.1335 & 0.1337 & 0.002 & 5.0 & 2.25 & 2.2 & 0.011 & 1.52 & 3.3 \\
\hline 031 & 0.1308 & - & 0.1339 & 0.1331 & 0.008 & 4.3 & 1.36 & 3.2 & 0.019 & - & - \\
\hline 032 & 0.1308 & - & 0.1337 & 0.1335 & 0.002 & 5.0 & 2.14 & 2.3 & 0.016 & 1.49 & 3.4 \\
\hline 033 & 0.1295 & - & 0.1329 & 0.1323 & 0.006 & 5.2 & 2.00 & 2.6 & 0.003 & 1.42 & 3.7 \\
\hline 034 & 0.1318 & - & 0.1339 & 0.1332 & 0.007 & 2.6 & 1.61 & 1.6 & 0.006 & - & - \\
\hline 036 & 0.1321 & - & 0.1342 & 0.1329 & 0.013 & 1.5 & 0.54 & 2.8 & 0.012 & - & - \\
\hline 013 & high side & & 0.1378 & 0.1376 & 0.002 & 14.7 & 3.0 & 4.9 & - & $3.0^{\mathrm{c}}$ & - \\
\hline 013 & high spot ( & ottom) & 0.1400 & 0.1400 & 0.000 & 19.1 & 4.2 & 4.5 & - & $3.0^{\mathrm{c}}$ & - \\
\hline
\end{tabular}

a. The core thickness change (swelling calculation) is based on a core thickness of $0.054 \mathrm{~cm}$ for all except the 50 vol $\% \mathrm{UAl}_{2}$ for which $0.055 \mathrm{~cm}$ was used (see Table 2). The original plate thickness was used for all plates except those for which the reference plate thickness is shown.

b. Table 13 plus 10\%. The low punch fission density plus $10 \%$ gives an average fission density equivalent to the CSAP PDQ average. See Section 3.11 .

c. Table 13 .

values $^{\mathrm{a}}$ and the calculated core thickness change is given in Table 5; a comparison with immersion density and plate thickness measurements is also given. It is noted that core thickness change, as measured by metallography, is larger than the

a. If an attempt is made to correct the average thickness values by multiplying by the ratio of the oxide stripped plate thickness (Table 4) to the metallography measured plate thickness, the percent thickness change becomes more random with respect to burnup. Rounding of the plate during polishing apparently produces this effect; hence, the average measured core thickness from the metallography was used. immersion density change or the plate core thickness change. Since the metallurgical core thickness change includes changes due to reaction of the fuel with the cladding, as well as that due to swelling, the larger values seem reasonable. Photographs of plates No. 002 and 014, used for metallography and not irradiated, are shown at 50X in Figure 6(a) and (b). Photographs of plates No. 007 and 013 after irradiation are shown in Figure 6(c) and (d). The voidage or brittle phase pullout during polishing appears similar in photographs taken before and after irradiation of plates from the same 


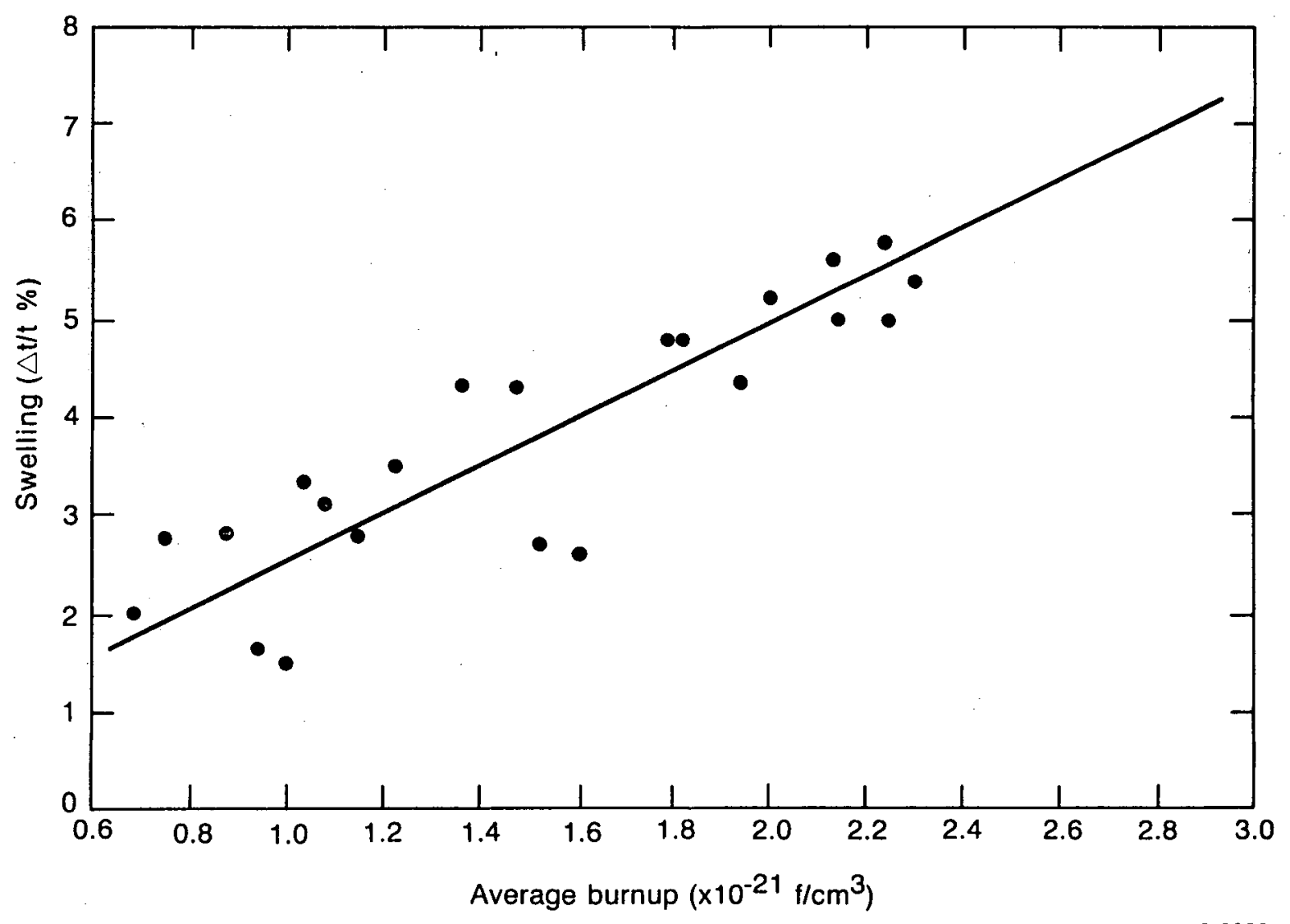

Figure 5. Core swelling versus burnup from thickness measurements.

composition group (50 vol\% $\mathrm{UAl}_{3}$, for plates No. 002 and 007 ; and $50 \mathrm{vol}^{\circ} \mathrm{UAl}_{2}$ for plates No. 014 and 013). An image analysis of the voidage was made as seen in Table 6.

From the comparison in Table 6 for plates 007 and 013 which were irradiated, and plates 002 and 014 which were not, it is seen that the void volume has not changed much with the core thickness increase due to irradiation.

A comparison of average core thickness of the four groups (50 vol\% $\mathrm{UAl}_{3}, 50 \mathrm{vol} \% \mathrm{UAl}_{2}$, 45 vol\% $\mathrm{UAl}_{2}$, and 40 vol\% $\mathrm{UAl}_{2}$ ) as determined from the core volume and radiographic surface area, ${ }^{a}$ with that of the metallurgical core thickness measured before irradiation ${ }^{\mathrm{a}}$ and after irradiation ${ }^{\mathrm{b}}$ gives an indication of the relative stability of the three aluminide phases $\left(\mathrm{UAl}_{2}, \mathrm{UAl}_{3}\right.$ and $\left.\mathrm{UAl}_{4}\right)$. As
a. Table 2 .
b. Table 5 .

is seen in Table 7 , the $50 \mathrm{vol} \% \mathrm{UAl}_{2}$ changes most during plate fabrication with an $11.8 \%$ change in core thickness. It is noted, however, that the total change from fabrication and irradiation is about the same as for the other groups at $13 \%$ total change.

\subsection{Metallography}

The metallography was done on $3 / 8 \times 3 / 4$ in. punchings from the middle of the fuel plate (Figure 3). A metallography sample was taken from each of the 12 plates. The aim of the metallography was to show the microstructure of the core and cladding, the clad-core interface, the thickness of the core and cladding, and the integrity of the fuel. The sections were examined on the metallograph and on the scanning electron microscope. For the examination, the sections (punchings) were mounted and polished with 6 and then 3 micron diamond paste. The samples were then polished and etched with Magomet No. 40-6440AB (MgO, 1-5 micron, $\mathrm{pH} 8-9.5$ in water). A repolish was 
Table 5. Comparison of metallurgical core thickness change with immersion density change and plate thickness change

\begin{tabular}{|c|c|c|c|c|c|}
\hline $\begin{array}{c}\text { Plate } \\
\text { Number }\end{array}$ & & $\begin{array}{c}\text { Average } \\
\text { Core } \\
\text { Thickness } \\
\text { (cm) } \\
\end{array}$ & $\begin{array}{c}\text { Metallurgical } \\
\text { Core } \\
\text { Thickness } \\
\text { Change } \\
(\%) \\
\end{array}$ & $\begin{array}{c}\text { Immersion } \\
\text { Density } \\
\text { Change } \\
(\%) \\
\end{array}$ & $\begin{array}{c}\text { Plate- } \\
\text { Core } \\
\text { Thickness } \\
\text { Change } \\
(\%) \\
\end{array}$ \\
\hline 005 & & 0.0615 & 13.9 & 1.81 & 4.8 \\
\hline 006 & & 0.0601 & 11.7 & 3.03 & 5.4 \\
\hline 007 & & 0.0625 & 14.7 & 1.54 & 4.3 \\
\hline & Avg & 0.0613 & & & \\
\hline 013 & & 0.0634 & 14.6 & 4.88 & 8.4 \\
\hline 019 & & 0.0628 & 14.8 & 3.16 & 5.6 \\
\hline 020 & & 0.0605 & 8.8 & 3.43 & 5.8 \\
\hline & Avg & 0.0622 & & & \\
\hline 022 & & 0.0607 & 12.8 & 2.56 & 4.8 \\
\hline 027 & & 0.0605 & 12.2 & 1.86 & 4.3 \\
\hline 028 & & 0.0628 & 16.9 & 4.29 & 6.5 \\
\hline & Avg & 0.0613 & & & \\
\hline 030 & & 0.0601 & 10.9 & 2.74 & 5.0 \\
\hline 032 & & 0.0593 & 10.6 & 3.60 & 5.0 \\
\hline 033 & & 0.0597 & 11.4 & 2.52 & 5.2 \\
\hline & Avg & 0.0597 & & & \\
\hline
\end{tabular}

done by hand on one sample, and etched with $15 \%$ sulfuric acid $/ 85 \%$ hydrogen peroxide. The results of the acid etch will be described in the scanning electron microscopy section.

The thickness of the core and cladding of the $50 \mathrm{vol} \% \mathrm{UAl}_{3}$ and $50 \mathrm{vol} \% \mathrm{UAl}_{2}$ is shown in Figure 6. The thickness has been discussed in the section on thickness changes. The voidage before and after irradiation appears to be about the same at $50 \mathrm{X}$ and was measured by image analysis as about the same. Thus, although the voidage has not filled with the swelling, the integrity of the fuel looks sound (free from blisters and cracks).

Although the metallography samples were punched to include all of the core (Figure 3), so that the effect of the burnup peaking might be examined, it was not evident in the metallography samples. The fuel structure looked sound at the ends of the plate width. Scanning electron microscopy was more limited in the extent of scanning that could be achieved, but no effect was detected by SEM. The structure looked sound except for some small bubbles which will be described in Section 3.6.

The microstructure of the core and cladding is shown in Figure 7(a) through (d) for the 50 vol\%
$\mathrm{UAl}_{3}$ and 50 vol $\% \mathrm{UAl}_{2}$ at $200 \mathrm{X}$ and $500 \mathrm{X}$. Although the cladding microstructure shows a tangled structure due to irradiation damage, the integrity of the fuel looks good. A fission fragment stopping zone (at the fuel-clad interface) can be seen, which is about 10-20 microns in width. This zone etches lighter than the $6061 \mathrm{Al}$ cladding. The polished and etched (Magomet) fuel surface looks sound, so that few bubbles can be seen in the surface at $500 \mathrm{X}$. In Figure 8 (a) through (d), the microstructure of the polished surface of the $45 \mathrm{vol} \%$ and 40 vol $\%$ fuel core composition can also be seen at 200X and 500X. Again, the microstructure looks sound. No bubbles or cracks can be seen in fuel grains. An effort was not made to distinguish metallographically the relative amounts of the three phases $\mathrm{UAl}_{2}, \mathrm{UAl}_{3}$ and $\mathrm{UAl}_{4}$ in the fuel grains, since the plates were irradiated at a temperature $\left(120^{\circ} \mathrm{C}\right)$ making this distinction difficult. The Magomet etch just makes the phases discernible (Figure 9). It was expected that reductions in the relative amounts of $\mathrm{UAl}_{2}$ and $\mathrm{UAl}_{3}$, because of reaction with the aluminum matrix, would occur as shown in Table 3, and as shown for plates irradiated at low temperature $\left(70^{\circ} \mathrm{C}\right)$ in the literature. ${ }^{10}$ As long as an excess of the aluminum matrix is present and bubbles and cracks are not seen, the 


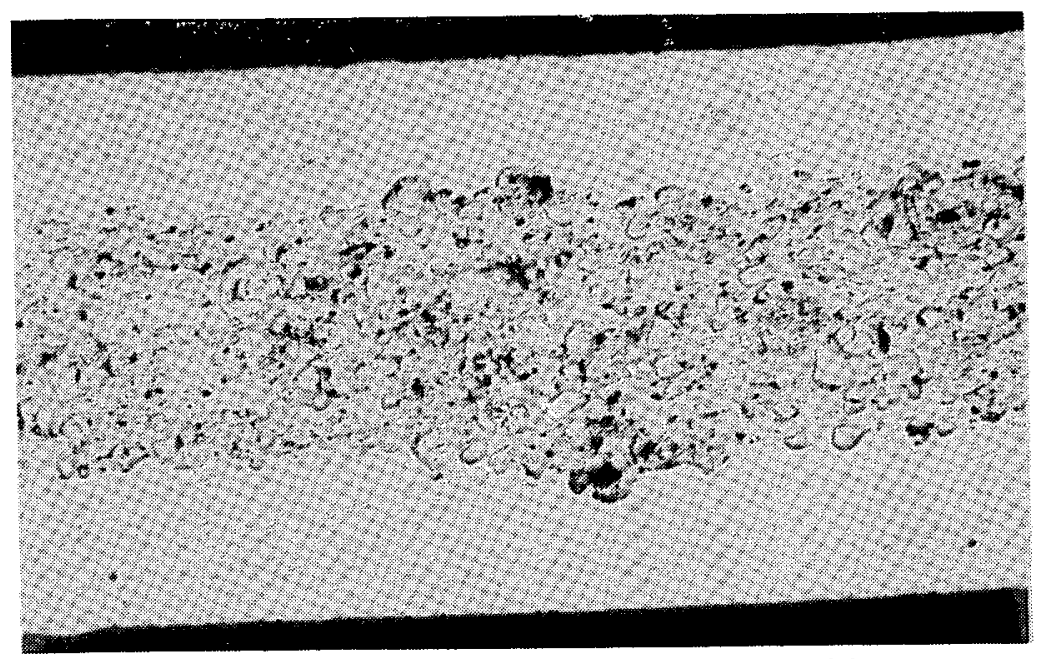

(a) Plate No. 002 before irradiation; composition 50 vol $\%, \mathrm{UAl}_{3}$, void vol. $6.2 \%, 50 \mathrm{x}$

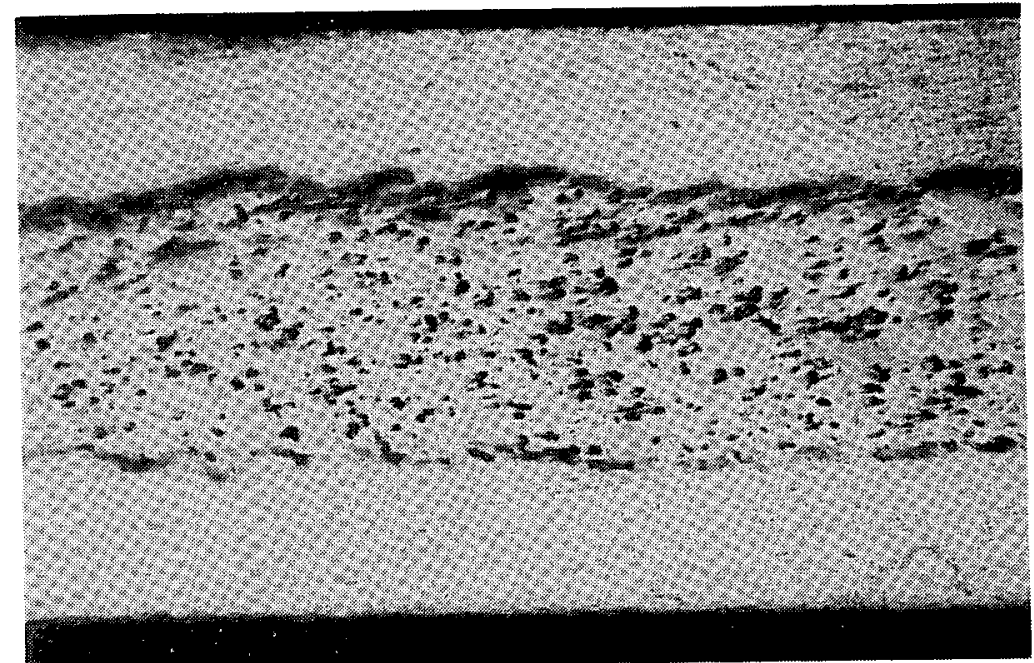

(c) Plate No. 007, burnup $1.48 \times 10^{21} \mathrm{f} / \mathrm{cm}^{3}$; composition 50 vol $\% \mathrm{UAl}_{3}$, void vol. $9.1 \% 50 \mathrm{x}$

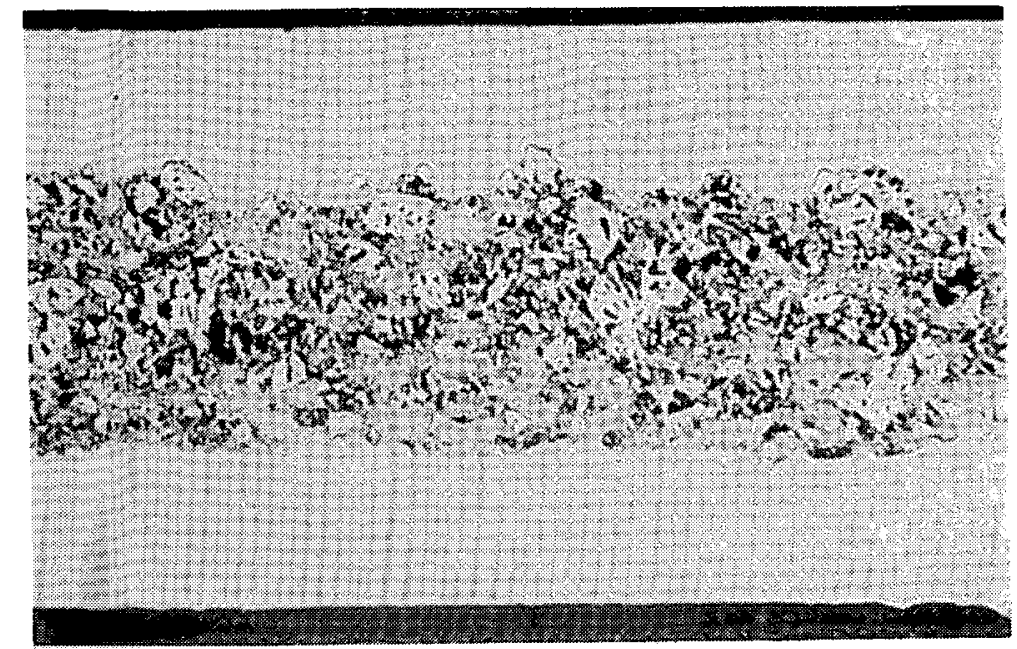

(b) Plate No. 014, before irradiation; composition 50 vol $\%, \mathrm{UAl}_{2}$, void vol. $8.3 \%, 50 \mathrm{x}$

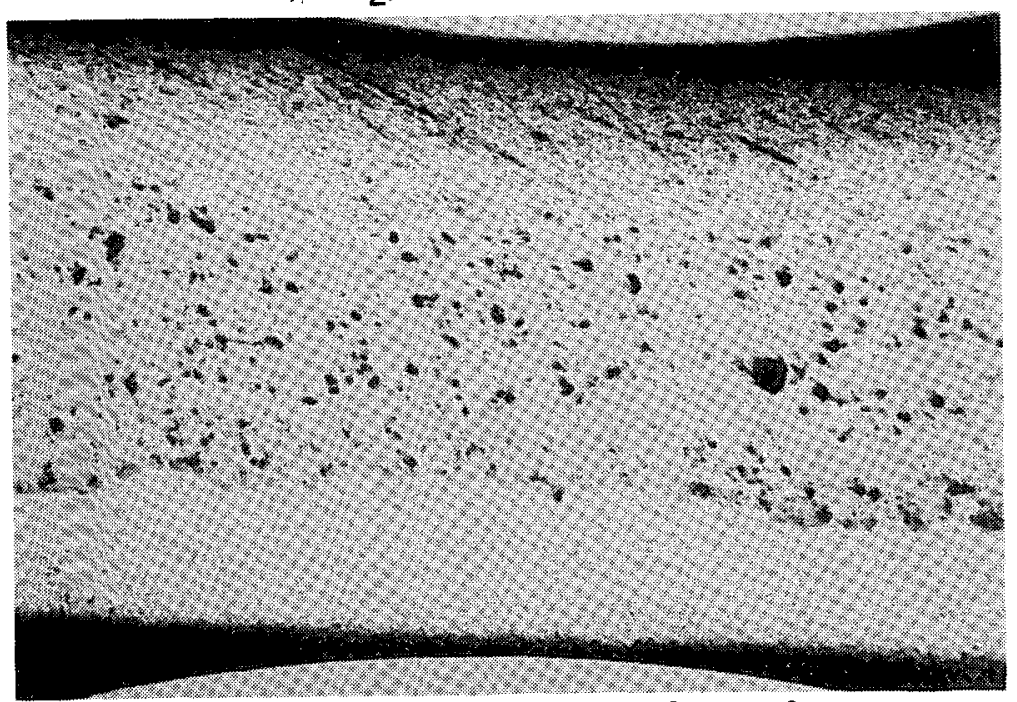

(d) Plate No. 013, burnup $2.98 \times 10^{21} \mathrm{f} / \mathrm{cm}^{3}$; composition 50 vol\% UAl 2 , void vol. $10.1 \% 50 x$

Figure 6. Plate and core thickness before and after irradiation. 


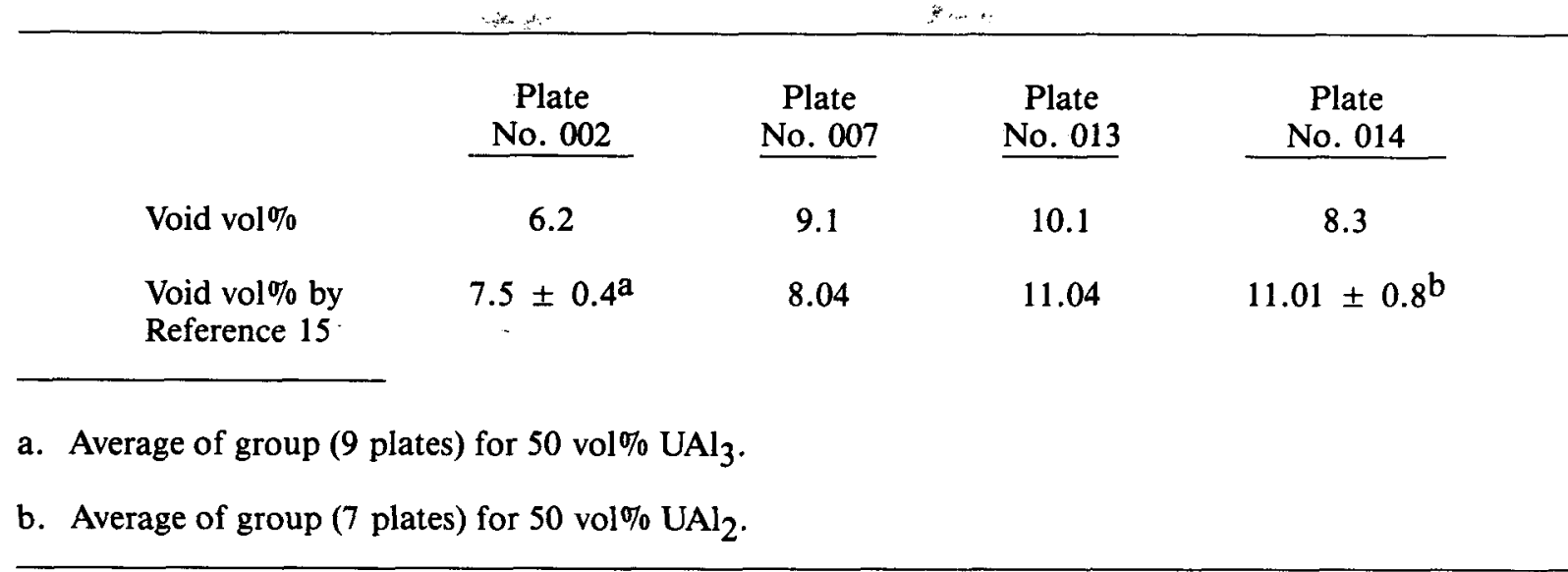

fuel core behavior is judged to be sound. An examination of the effect of the reactions was made by Scanning Electron Microscopy (SEM).

\subsection{Scanning Electron Microscopy}

Scanning electron microscopy was performed on fractured surfaces of the fuel as well as on the polished and etched surfaces. The examination of the fractured surfaces 16 will be discussed first. Small punchings ( $\sim 2 \mathrm{~mm}$ ) of plates 013 and 032 containing $\mathrm{UAl}_{2}$, and plate 006 containing $\mathrm{UAl}_{3}$, were obtained. ${ }^{16}$ The punchings were fractured through the fuel, and the fractured surface examined on the SEM by secondary and back scatter emission, and by Kevex-ray emission (Figures 10, 11, 12 and 13). The secondary emission photographs of plates 013 and 032 (Figures 10 and 11) show patches of voids, or small bubbles, and patches of ductile tearing of the aluminum matrix. The centers of the fuel grains are relatively free of any defects (voids or bubbles) at $600 \mathrm{X}$, and at higher magnification (2000X), Figure 13(a). Back scatter emission (Figure 12) shows a difference in contrast due to the three phases $\left(\mathrm{UAl}_{2}, \mathrm{UAl}_{3}\right.$, and $\left.\mathrm{UAl}_{4}\right)$ as was seen in Figure 9 by metallography. The identification of these three phases was made by Kevex-ray (Figure 13). A grain in Figure 12 (magnified to about 2000X and the regions identified as $2,3,4$ ) and a phase of U-O was examined by Kevex-ray and indicated in Figure 13(c), (d), (e) and (f). The regions were identified respectively, as $\mathrm{UAl}_{2}, \mathrm{UAl}_{3}, \mathrm{UAl}_{4}$, and a phase of $U$, probably an oxide. The presence of the $\mathrm{U}$ phase is surprising, although present in small amounts $(<1 \%)$. Small bubbles were associated with this $U$ phase. It was not detectable in the powder blend, nor in the compact examined by x-ray analysis (Table 3). The $U$ phase is found in void regions, where accessibility of aluminum is limited, or trapped oxygen would be present. It was also

Table 7. Comparison of core thickness change during fabrication and irradiation

\begin{tabular}{|c|c|c|c|c|c|c|c|}
\hline \multirow[b]{2}{*}{$\begin{array}{c}\text { Plate } \\
\text { Number } \\
\end{array}$} & \multirow[b]{2}{*}{$\begin{array}{c}\text { Principal } \\
\text { Composition } \\
\text { of Group } \\
\end{array}$} & \multirow{2}{*}{$\begin{array}{l}\text { Calculated } \\
\text { Average } \\
\text { Core } \\
\text { Thickness } \\
\text { (Table 2) } \\
\end{array}$} & \multicolumn{2}{|c|}{ Metallurgical } & \multirow[b]{2}{*}{$\begin{array}{c}\text { Change } \\
\text { After } \\
\text { Fabrication } \\
(\%) \\
\end{array}$} & \multirow[b]{2}{*}{$\begin{array}{c}\text { Change } \\
\text { After } \\
\text { Irradiation } \\
(\%) \\
\end{array}$} & \multirow[b]{2}{*}{$\begin{array}{c}\text { Total } \\
\text { Change } \\
(\%) \\
\end{array}$} \\
\hline & & & $\begin{array}{c}\text { Before } \\
\text { Irradiation } \\
\text { (Table 2) } \\
\end{array}$ & $\begin{array}{c}\text { After } \\
\text { Irradiation } \\
\text { (Table 5) } \\
\end{array}$ & & & \\
\hline 006-007 & $50 \mathrm{vol}_{0} \mathrm{UAl}_{3}$ & 0.0541 & 0.0574 & . $0.0613 \ldots$ & 6.1 & $6: 8$ & 12.9 \\
\hline 013-020 & 50 vol\% $\mathrm{UAl}_{2}$ & 0.0552 & 0.0617 & 0.0622 & 11.8 & 0.8 & 12.6 \\
\hline $022-028$ & 45 vol\% $\mathrm{UAl}_{2}$ & 0.0538 & 0.0572 & 0.0613 & 6.3 & 7.4 & 13.7 \\
\hline 030-033 & 40 vol $\% \mathrm{UAl}_{2}$ & 0.0538 & 0.0561 & 0.0597 & 4.3 & 6.4 & 10.7 \\
\hline
\end{tabular}




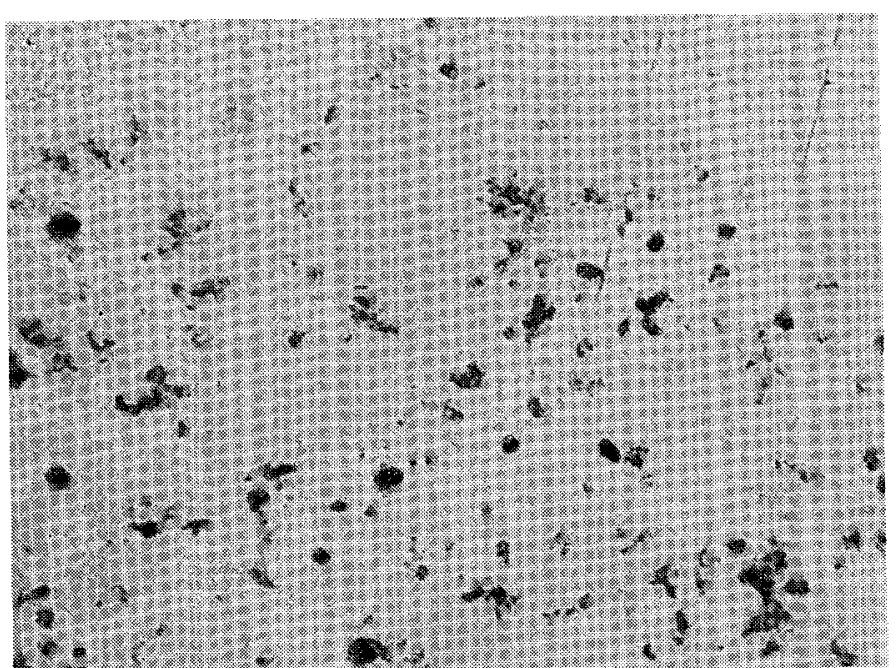

(a) Plate No. 005, composition 50 vol\% $\mathrm{UAl}_{3}$, burnup $1.8 \times 10^{21} \mathrm{f} / \mathrm{cm}^{3} 200 \mathrm{x}$

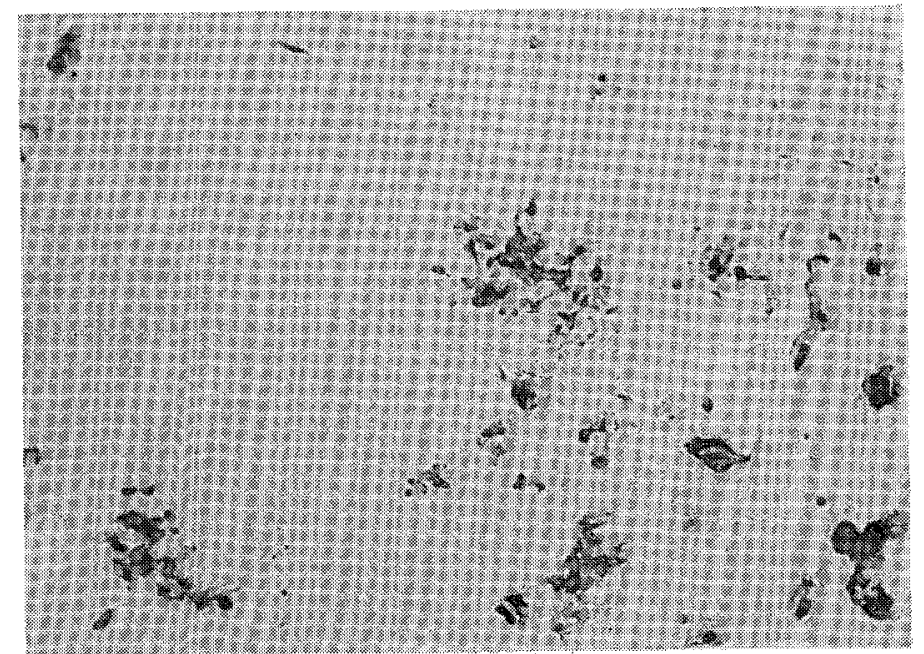

(c) Plate No. 005, composition 50 vol $\% \mathrm{UAl}_{3}$, burnup $1.8 \times 10^{21} \mathrm{f} / \mathrm{cm}^{3} 500 \mathrm{x}$

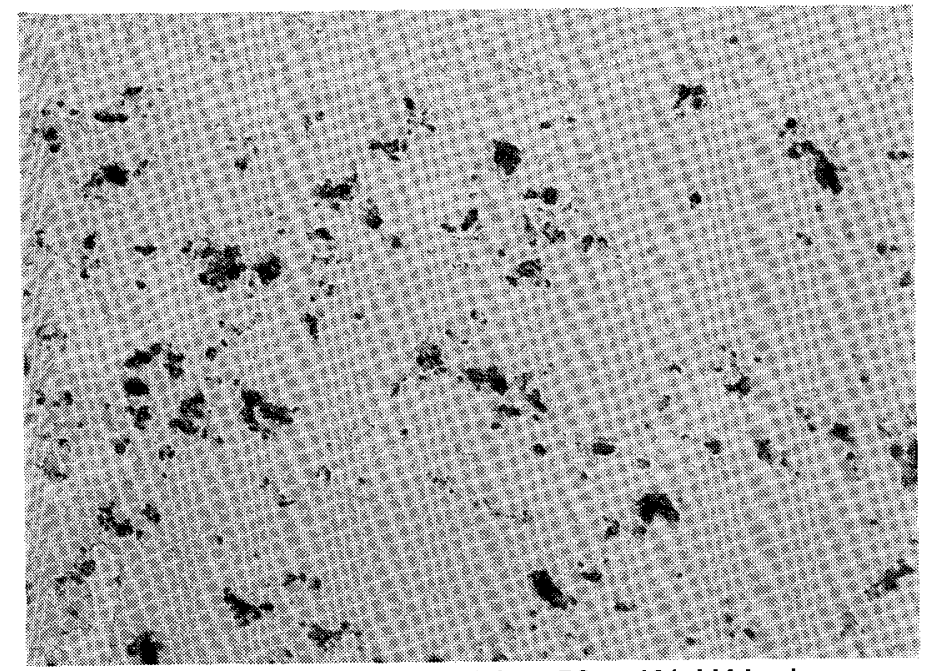

(b) Plate No. 013, composition 50 vol\% $\mathrm{UAI}_{2}$, burnup $2.98 \times 10^{21} \mathrm{f} / \mathrm{cm}^{3} 200 \mathrm{x}$

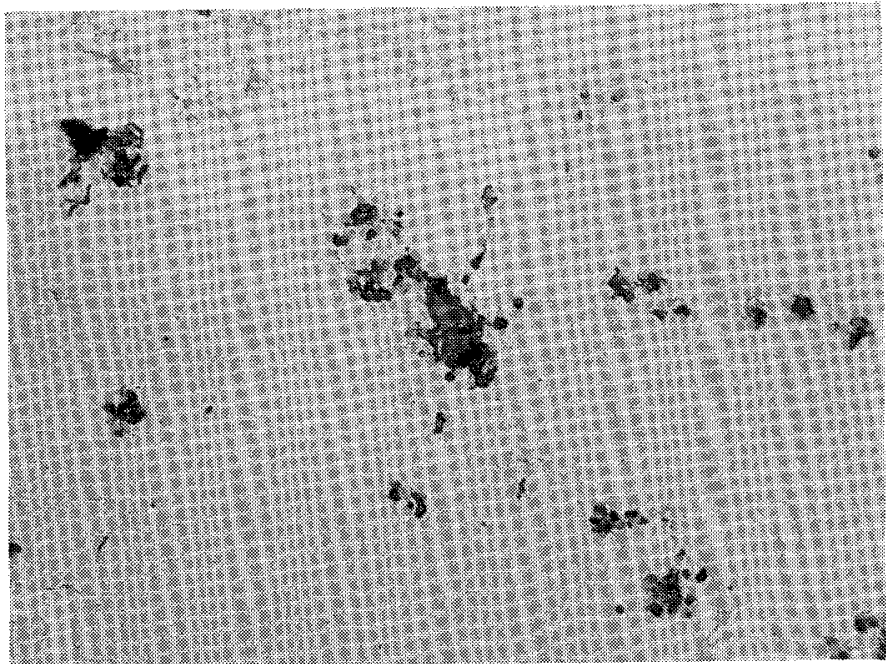

(d) Plate No. 013, composition 50 vol $\% \mathrm{UAl}_{2}$, burnup $2.98 \times 10^{21} \mathrm{f} / \mathrm{cm}^{3} 500 \mathrm{x}$

Figure 7. Microstructure of core and cladding of $50 \mathrm{vol}^{\circ} \mathrm{UAl}_{\mathrm{x}}$. 


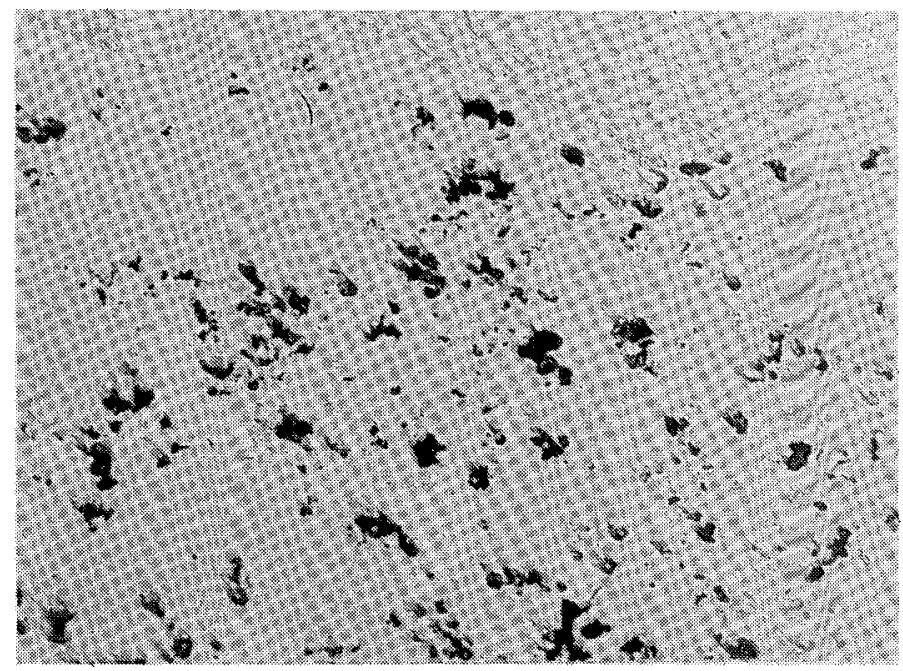

(a) Plate No. 027 , composition 45 vol\% UAl 2 , burnup $1.94 \times 10^{21} \mathrm{f} / \mathrm{cm}^{3} 200 \mathrm{x}$

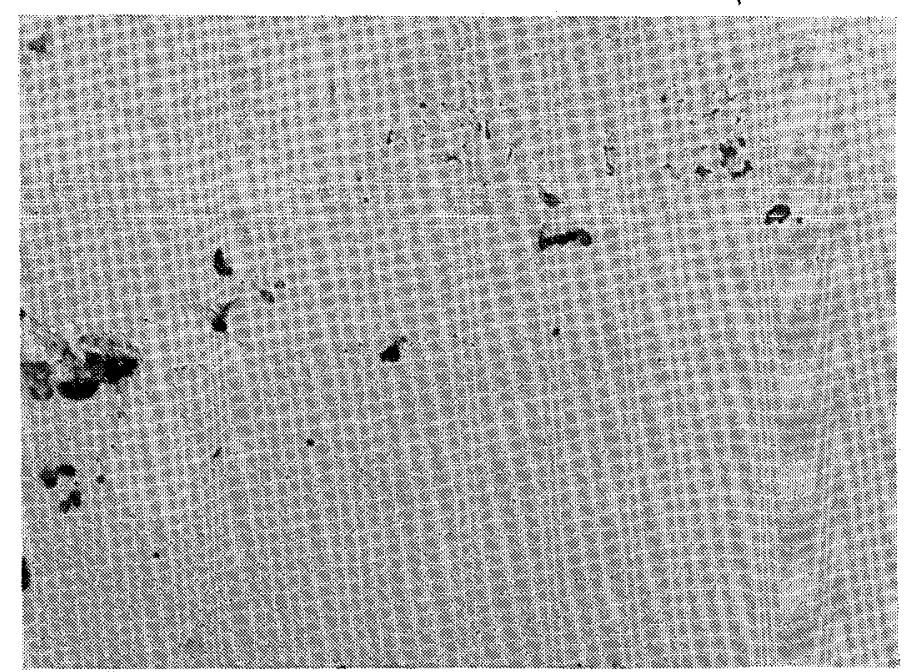

(c) Plate No. 027 , composition 45 vol $\% \mathrm{UAl}_{2}$, burnup $1.94 \times 10^{21} \mathrm{f} / \mathrm{cm}^{3} 500 \mathrm{x}$

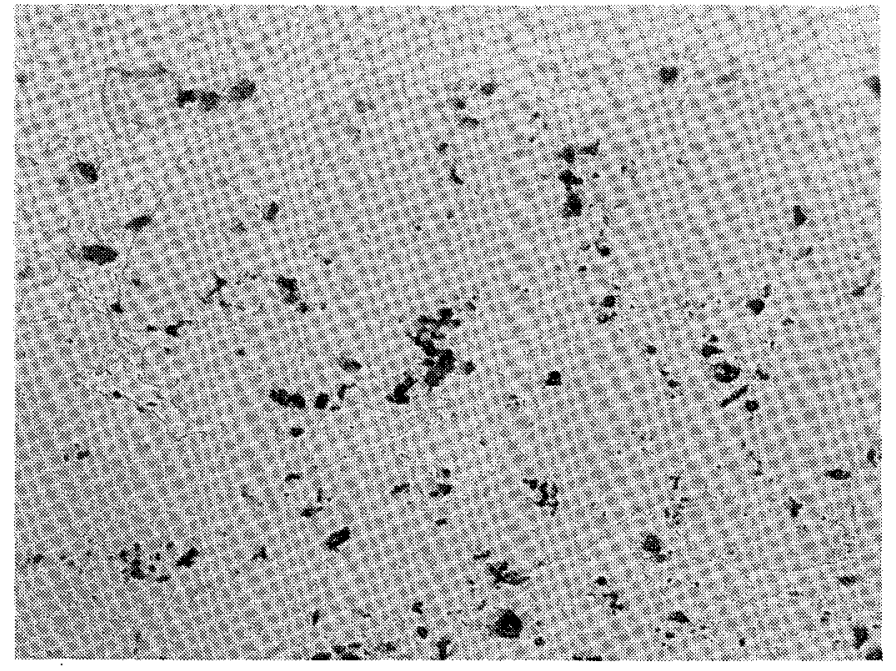

(b) Plate No. 033, composition 40 vol\% UAl2, burnup $2.0 \times 10^{21} \mathrm{f} / \mathrm{cm}^{3} 200 \mathrm{x}$

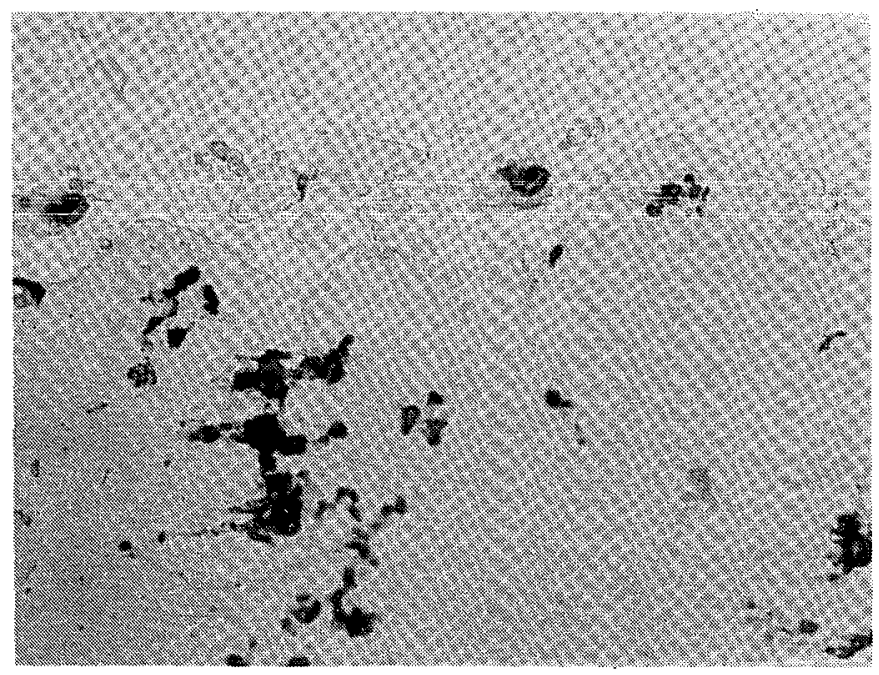

(d) Plate No. 033 , composition 40 vol $\% \mathrm{UAl}_{2}$, burnup $2.0 \times 10^{21} \mathrm{f} / \mathrm{cm}^{3} 500 \mathrm{x}$

Figure 8. Microstructure of $45 \mathrm{vol} \%$ and of $40 \mathrm{vol} \% \mathrm{UAI}_{2}$. 


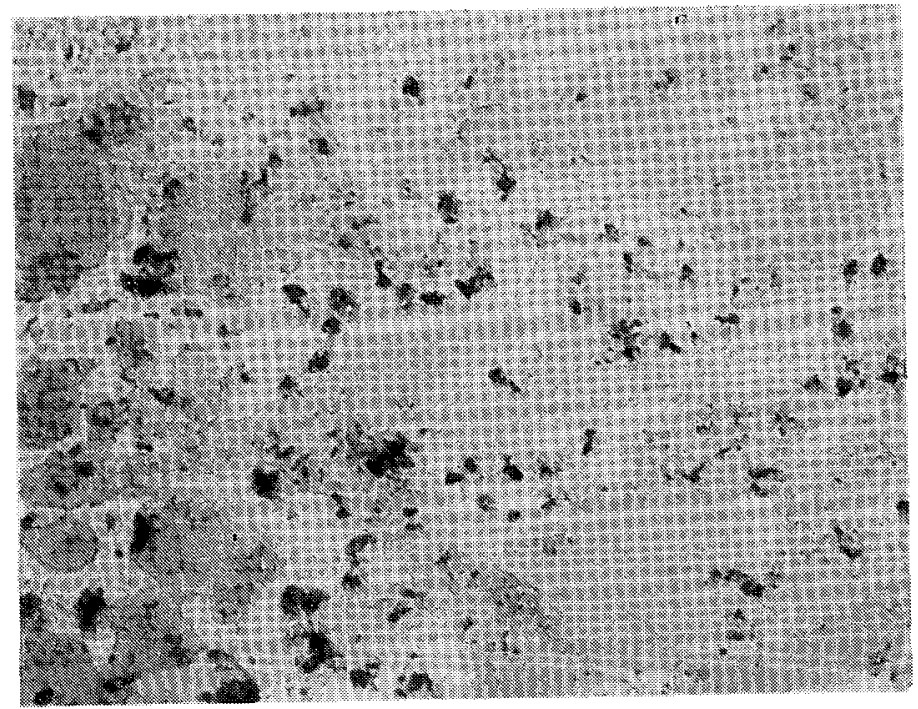

(a) Plate 032 metallography $200 x$

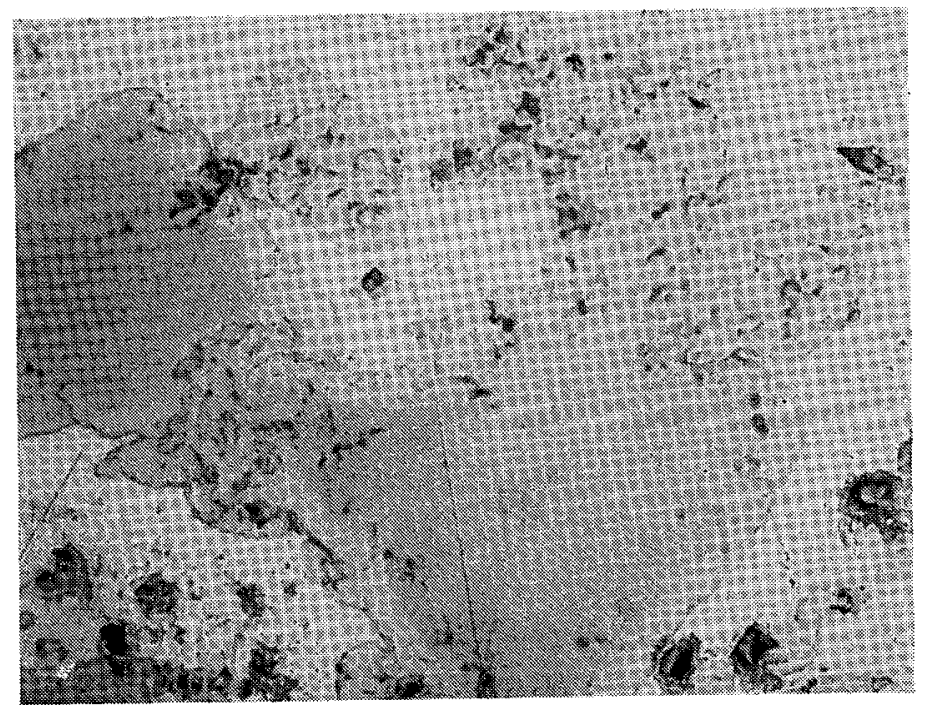

(b) Plate 032 metallography $500 x$

Figure 9. Fuel grains of $\mathrm{UAl}_{\mathrm{x}}$ in aluminum matrix. $\mathrm{UAl}_{2}, \mathrm{UAl}_{3}$ and $\mathrm{UAl}_{4}$ just discernable with Magomet etch. 


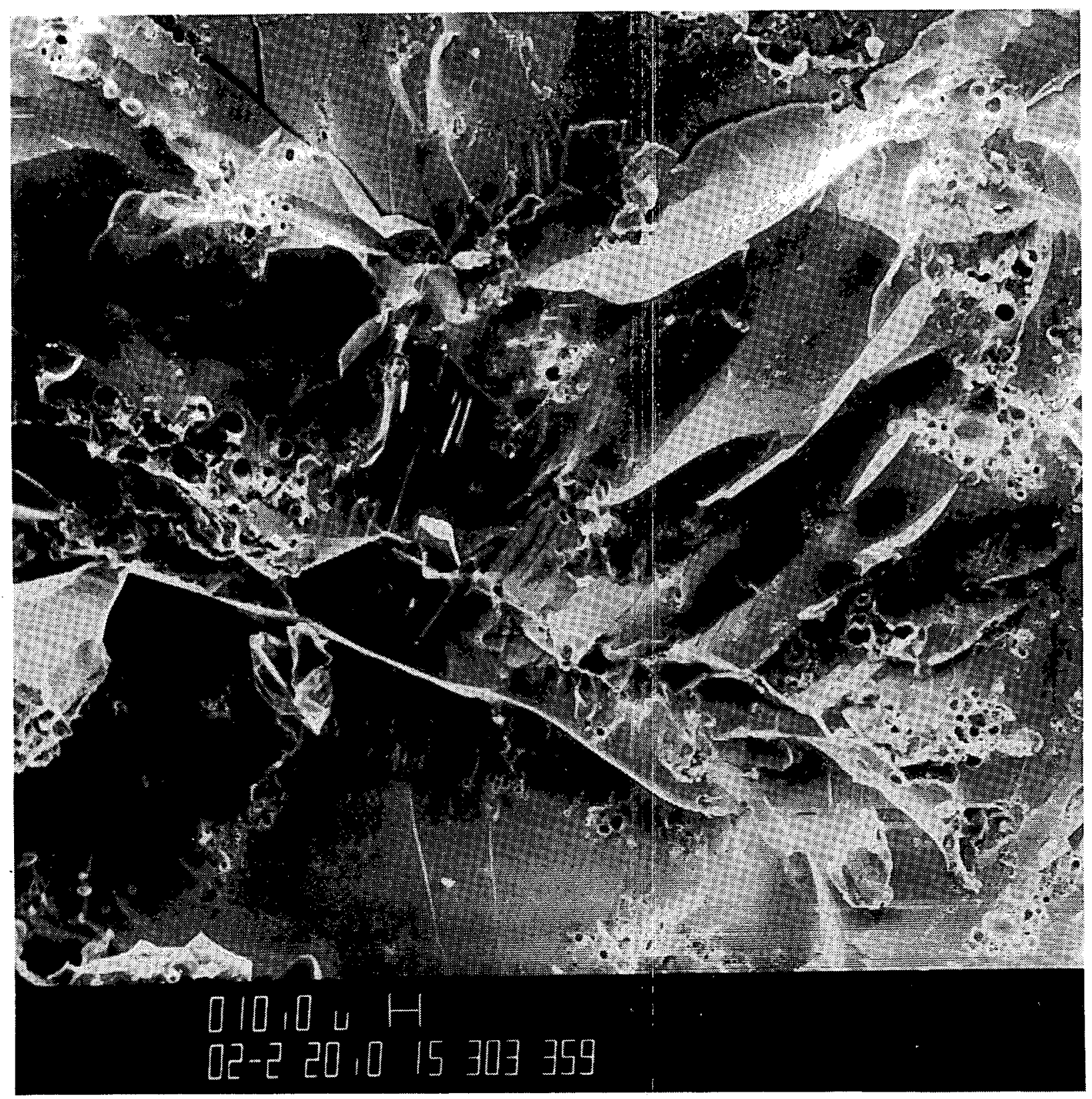

Figure 10. SEM photograph of fractured surface by secondary emission, plate 013 . 


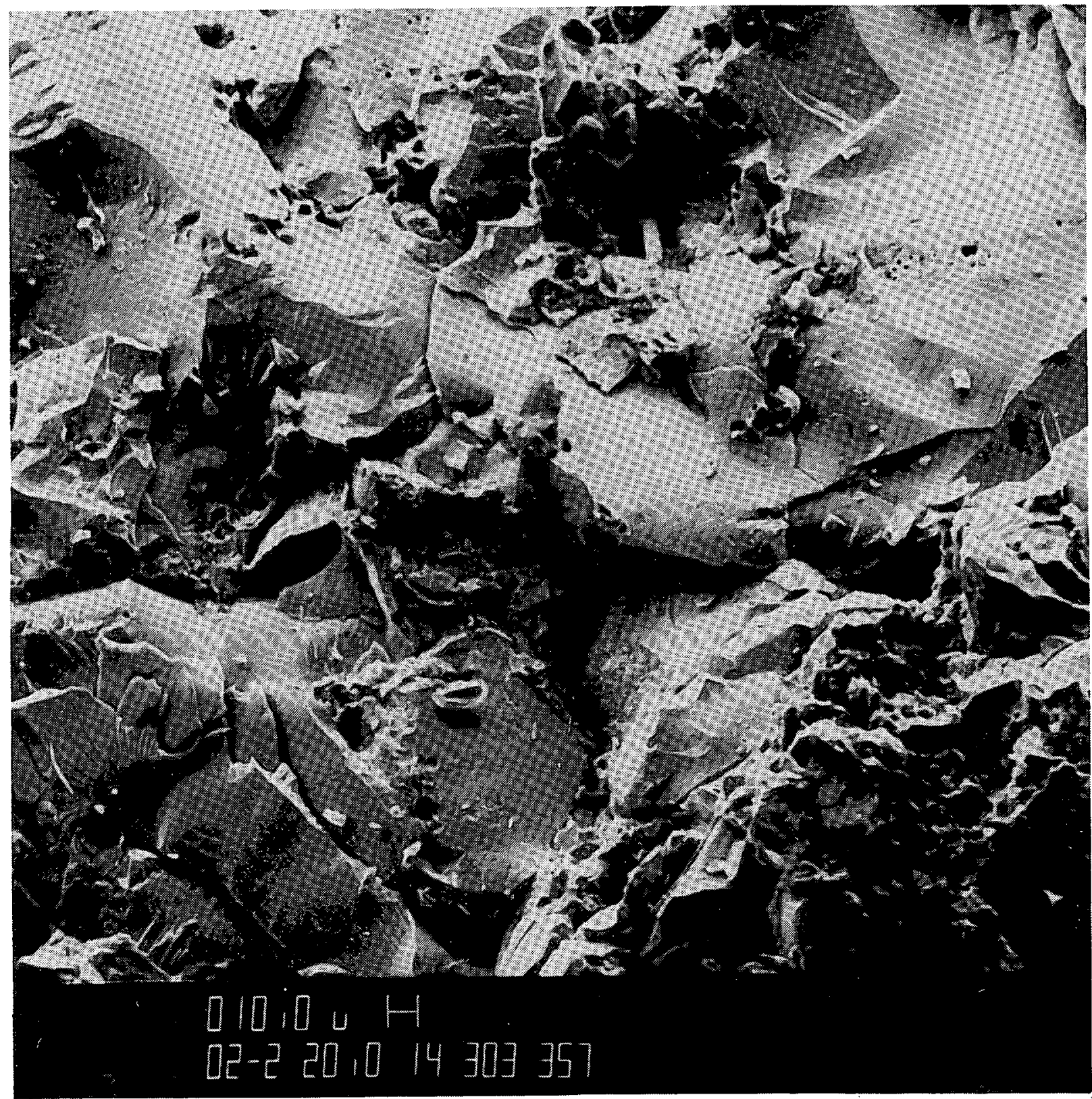

Figure 11. SEM photograph of fractured surface by secondary emission, plate 032 . 


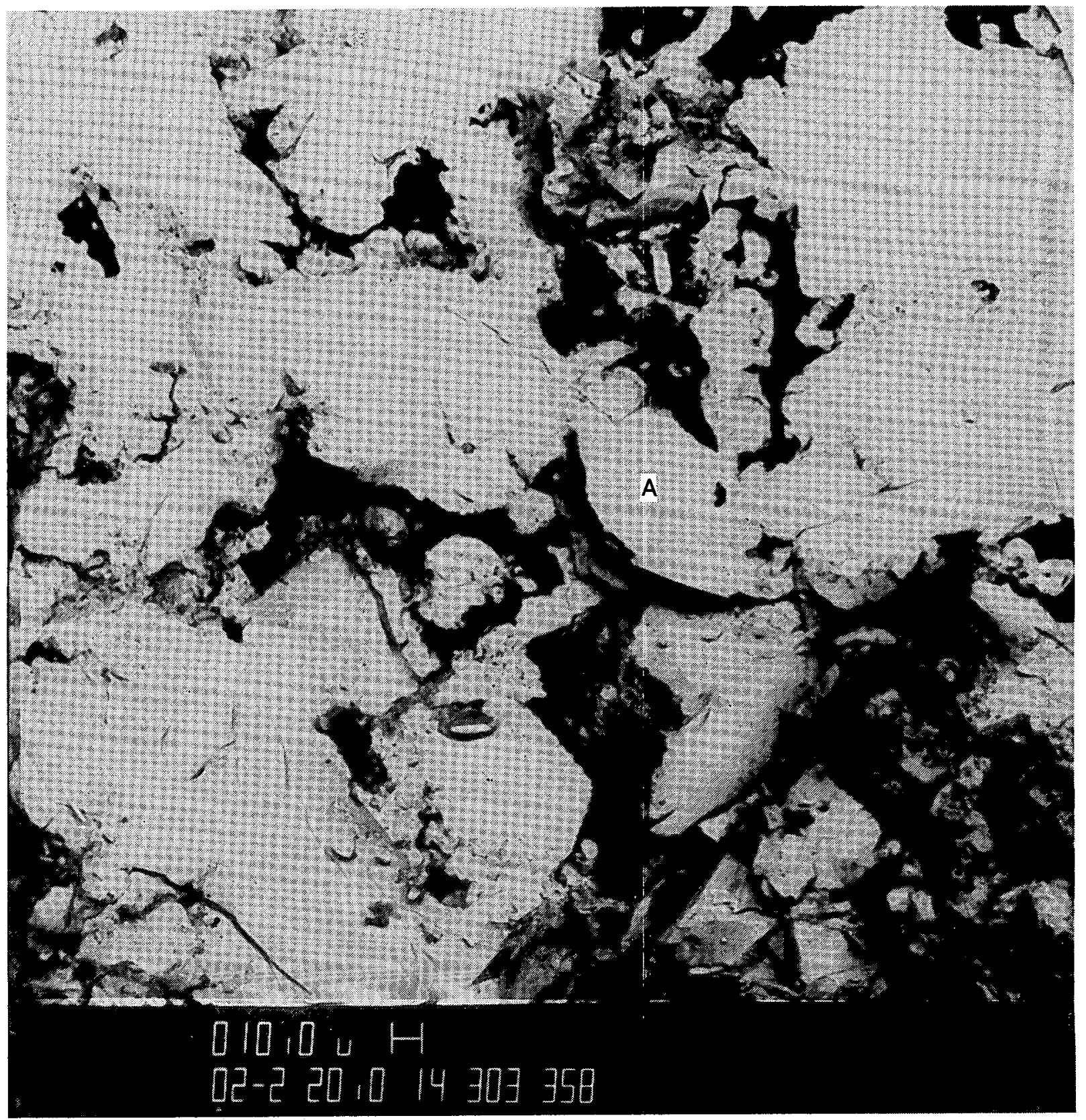

Figure 12. SEM photograph of fractured surface by back scatter emission (plate 032) identifies region A of Kevex-ray examination. 


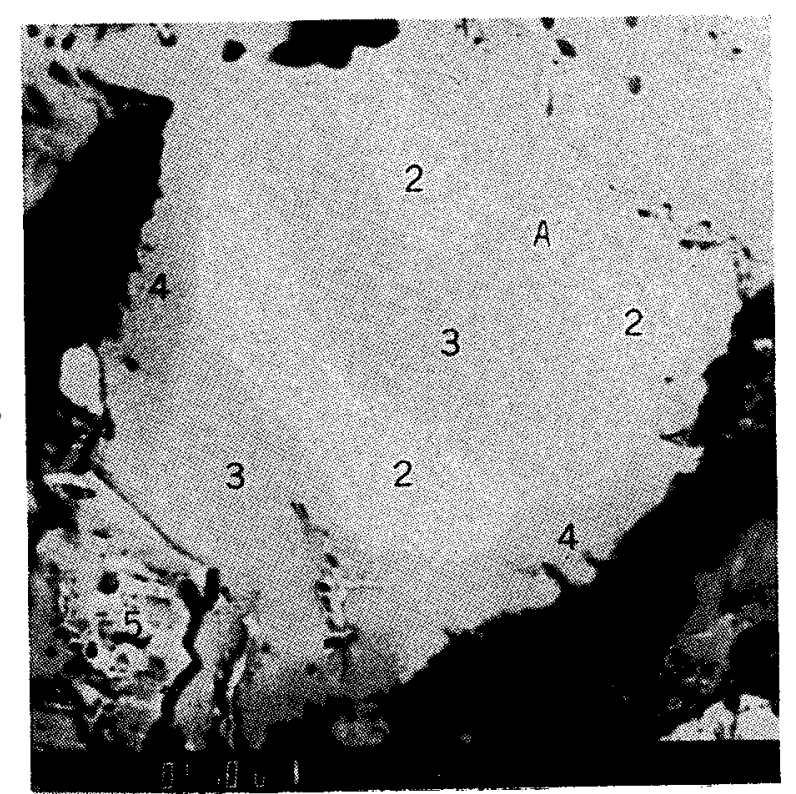

(a) Grain A for Kevex-ray examination

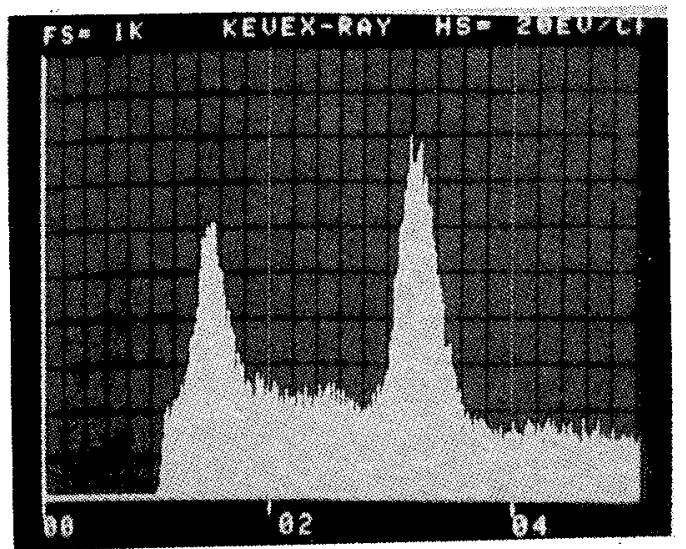

(c) Region 2, UAl2

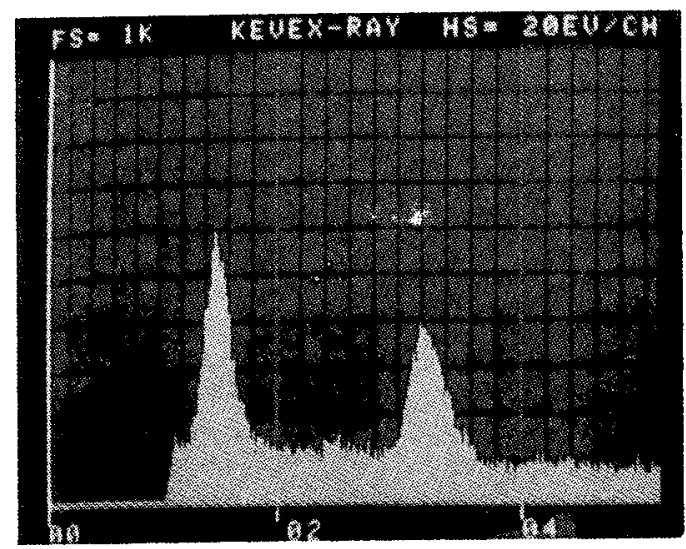

(e) Region 4, UAl2

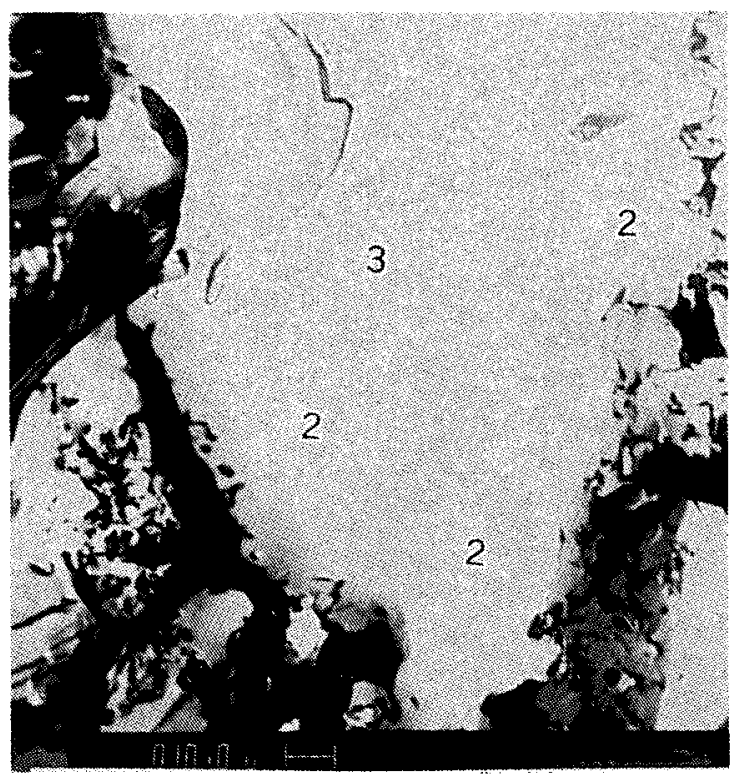

(b) Another fuel grain

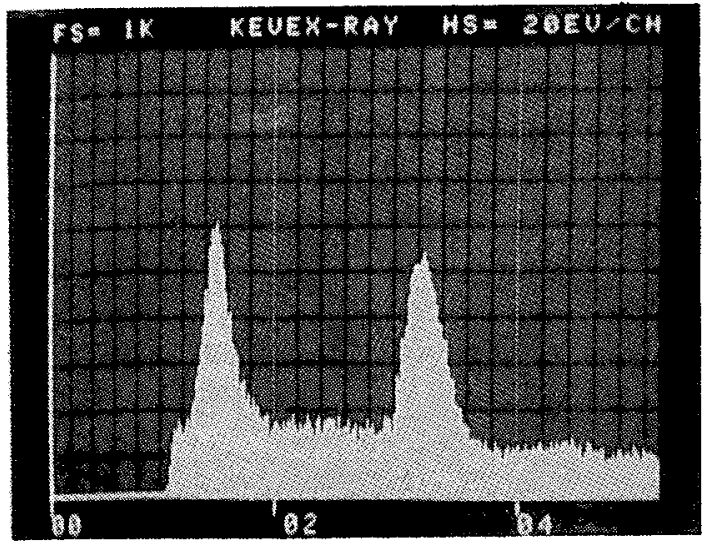

(d) Region 3, $\mathrm{UAI}_{3}$

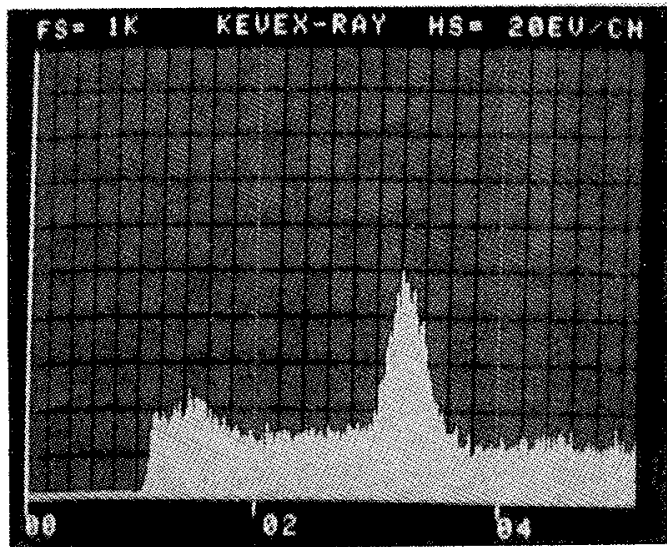

(f) Region 5, U

Figure 13. Examination of fuel grain $\mathrm{A}$ for $\mathrm{UAl}_{2}, \mathrm{UAl}_{3}, \mathrm{UAl}_{4}$ and $\mathrm{U}$. 
found at the outskirts of the fuel grains, where reaction with the aluminum matrix occurred; pickup of surface oxygen on aluminum powder would have taken place. The outskirts of the fuel grains are also the regions where $\mathrm{UAl}_{4}$ predominates. The photograph of Figure 13(a) was examined on the image analyzer to determine the percent of $\mathrm{UAl}_{2}, \mathrm{UAl}_{3}$, and $\mathrm{UAl}_{4}$ in that fuel grain. The percentages obtained were $\mathrm{UAl}_{2}, 17 \%$; $\mathrm{UAl}_{3}, 50 \%$; and $\mathrm{UAl}_{4}, 33 \%$. These percentages are to be compared with those of sample 038III-I that had received the heat treatment outgassing, hot rolling, and blister anneal $\left(925^{\circ} \mathrm{F}, 1 \mathrm{hr}\right)$. The percentages of sample $038 \mathrm{III}-\mathrm{I}$ are $\mathrm{UAl}_{2}, 20 \% \mathrm{UAl}_{3}, 75 \%$; and $\mathrm{UAl}_{4}, 5 \%$ (Table 3). Thus, irradiation has reduced the percent of $\mathrm{UAl}_{2}$ and increased the percentage of $\mathrm{UAl}_{4}$ present in the fuel grains.

Samples of the powder from $\mathrm{UAl}_{3}$ and $\mathrm{UAl}_{2}$ composition blends were examined by SEM for any evidence of uranium separate from aluminum. The Kevex-ray examination showed no uranium separate from aluminum in over 70 particles taken from each of the samples of the JJ and JF composition blends. Variances in the atomic percent of uranium and aluminum occurred. This was especially true in the weight percent; however, aluminum was always present with the uranium.

SEM examination was performed on the polished and etched surfaces of the metallography samples for any evidences of bubbles, cracking, or irradiation damage. The SEM surface examination was performed on an Amray SEM 1200B, which had been modified to accept irradiated samples. The top 1/4 in. of the metallurgical mounts were sliced on a Leeco Varicut saw and mounted on a SEM stem for insertion into the SEM. The surface was coated with gold (on an Ernest F. Fullam Sputter Coater at 100 microns vacuum) to provide surface conductivity and enhance contrast. The surface was examined at $200 \mathrm{X}, 500 \mathrm{X}, 1000 \mathrm{X}$, and $3000 \mathrm{X}$ on all 12 samples. Any difference in irradiation damage was slight. A polishing and etching effect between the Magomet.and the $15 \%$ sulfuric acid - hydrogen peroxide was noticed, wherein some of the Magomet particles were trapped in the voids or etch pits. These were small, less than 5 microns, and randomly distributed in the cladding as well as the fuel. These white Magomet particles were eliminated after the repolish and etch with $15 \%$ sulfuric acid - hydrogen peroxide.

Representative photographs of low burnup plates (No. 007 and No. 019) from 50 vol\% groups, as well as representative photographs of plates of high burnup from each composition group are presented (e.g., plate No. 006 from 50 vol\% $\mathrm{UAl}_{3}$; plate No. 013 from $50 \mathrm{vol} \% \mathrm{UAl}_{2}$; plate No. 028 from 45 vol $\% \mathrm{UAl}_{2}$; and plate No. 030 from 40 vol\% $\quad \mathrm{UAl}_{2}$ ), Figures 14 through 19. Photographs of plate No. 013, after the repolish and acid etch, are also shown, Figure 20. The SEM photographs, with their larger depth of field at focus, show the fabrication voids more clearly than the metallography photographs. For example, compare Figure 7(c) of plate No. 005 with Figure 14(a) of plate No. 007 (both at 500X). The low burnup of the 50 vol\% $\mathrm{UAl}_{3}$ (plate No. 007) and the 50 vol $\% \mathrm{UAl}_{2}$ (plate No. 019) show little difference in fuel damage (Figures 14 and 15). The four compositions (50 vol\% $\mathrm{UAl}_{3}$, 50 vol $\% \mathrm{UAl}_{2}, 45$ vol $\% \mathrm{UAl}_{2}$, and 40 vol $\% \mathrm{UAl}_{2}$ ) also show little difference in damage to the fuel (Figures 16, 17, 18, and 19). The white bubbles appearing in Figures 14 through 19 (where the plates were finished with a Magomet polish-etch) are eliminated in Figure 20(a) through 20(f) (where they were repolished with 6 and then 3 micron diamond paste and acid etched). The cladding in Figure 20(f) shows some etch pits. These pits were present in the cladding of all the plates.

\subsection{Blister Tests}

Blister testing is used as a means of evaluating the behavior of the fuel core with respect to fission gas agglomeration. As the fission gas agglomerates, visible blistering of the fuel plate surface occurs. The blister test is conducted by starting at a furnace temperature slightly above the peak plate operating temperature, and heating in successive increased temperature steps for periods of one-half hour. Thus, at a temperature above the third from the last step, the plate section would have been heated for one and one-half hours, plus longer times at lower temperatures. When a blister is first discerned, the test is terminated for that sample.

The maximum nominal and two sigma plate operating temperatures were $395 \mathrm{~K}$ and $407 \mathrm{~K}$, respectively, which decreased with operating time. The initial heating temperature step was at $563 \mathrm{~K}$ for one-half hour. Since the blister test heating is terminated after the blisters are visually detected, the blister temperature for a one hour anneal is taken as the step temperature before the test is terminated and blisters are visually detected. The 


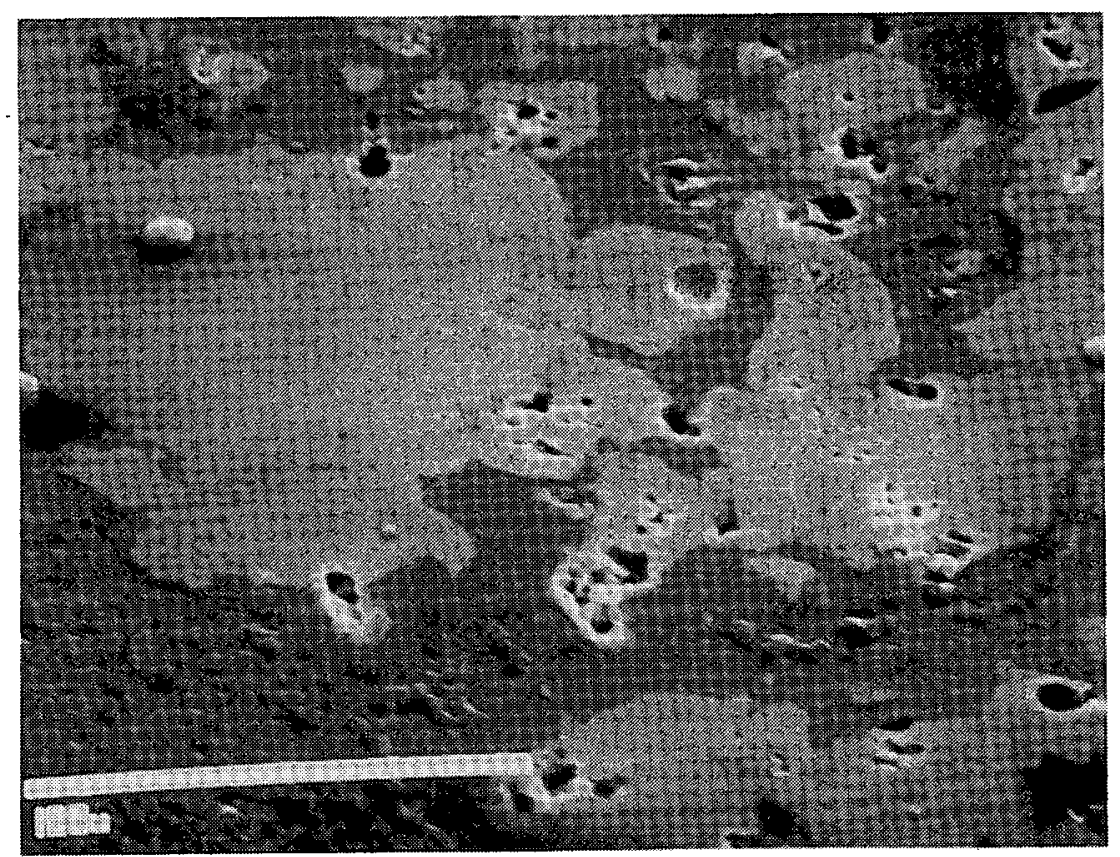

(a) Fuel at $500 x$, dark area is matrix aluminum

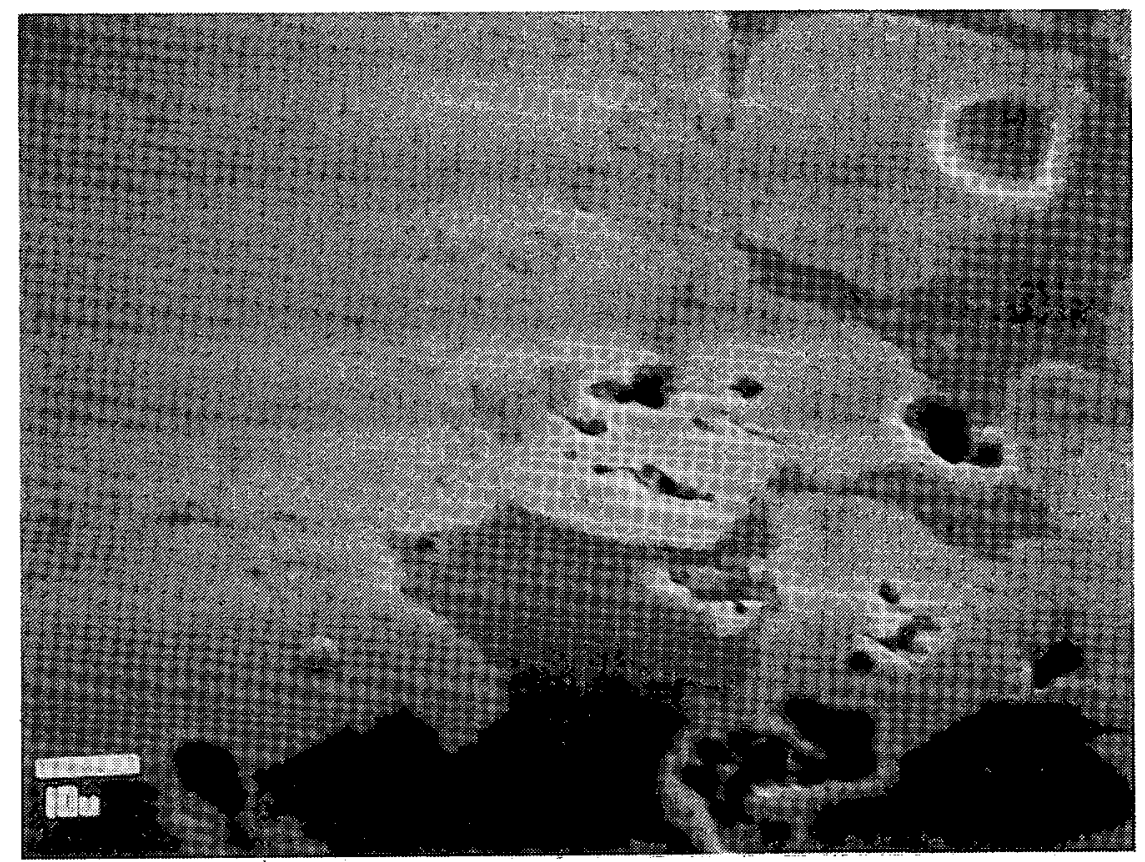

(b) Fuel at $1000 \mathrm{x}$, dark area is matrix aluminum

Figure 14. SEM photographs of plate 007 , composition 50 vol\% $\mathrm{UAl}_{\mathrm{x}}$. 


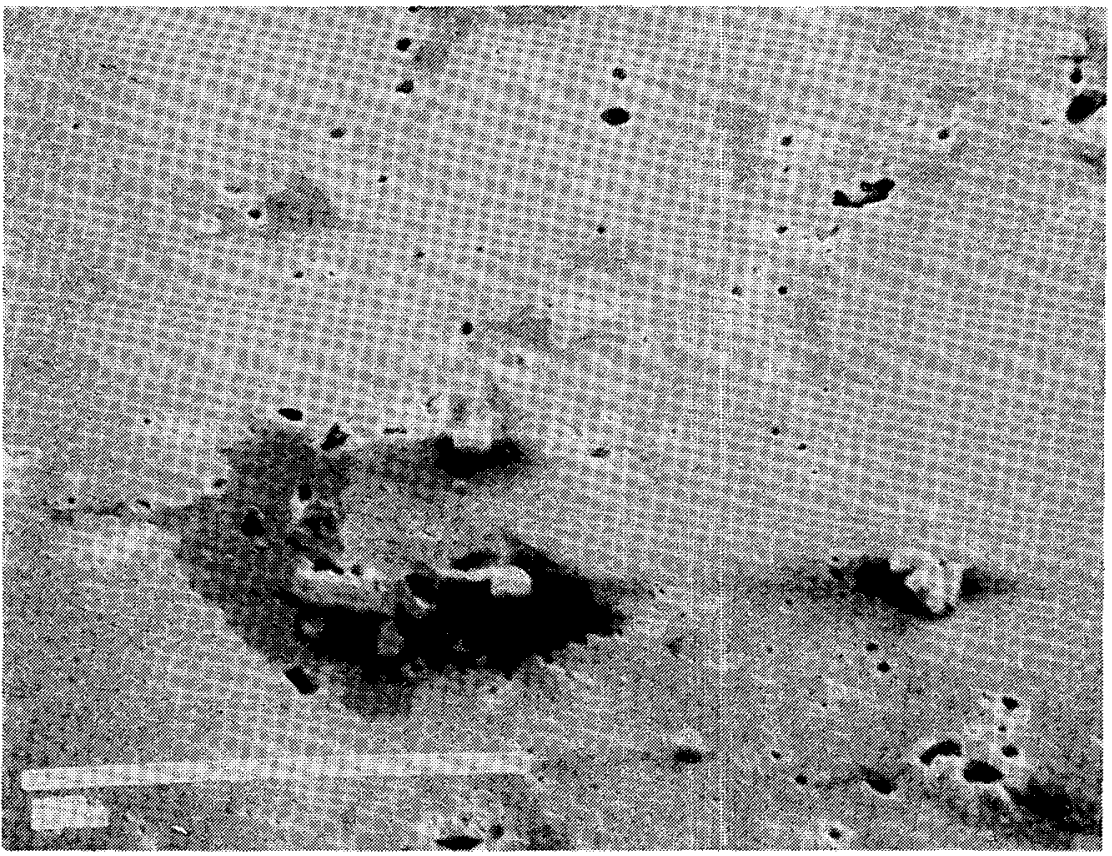

(a) Fuel at $500 x$

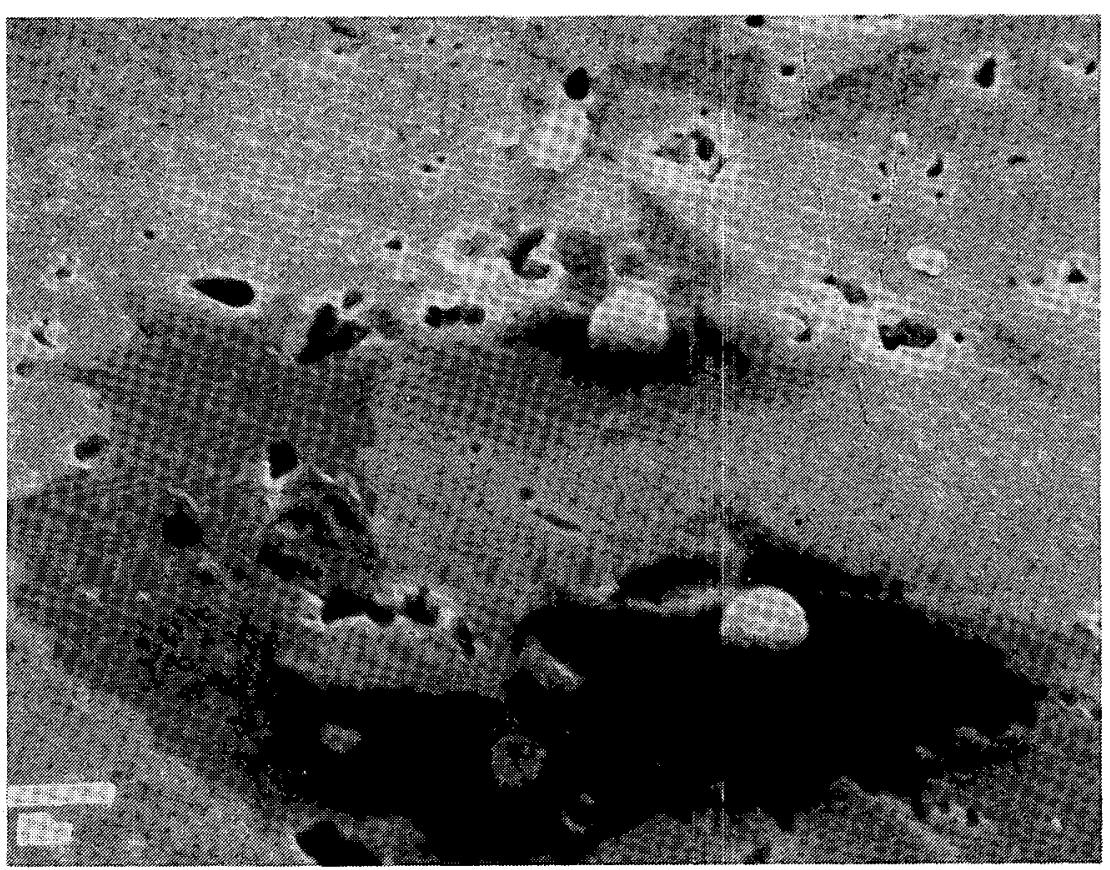

(b) Fuel at $1000 \mathrm{x}$

Figure 15. SEM photographs of plate 019 , composition $50 \mathrm{vol} \% \mathrm{UAl}_{2}$. 


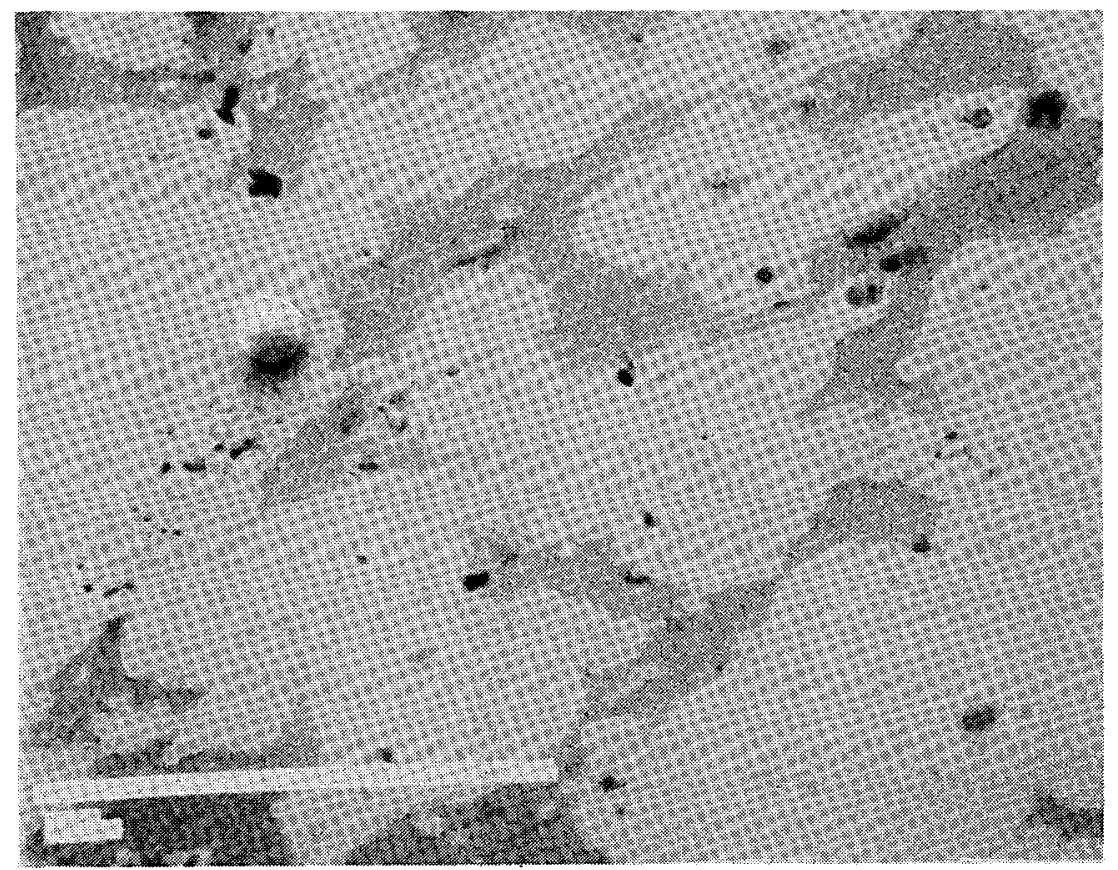

(a) Fuel at $500 x$

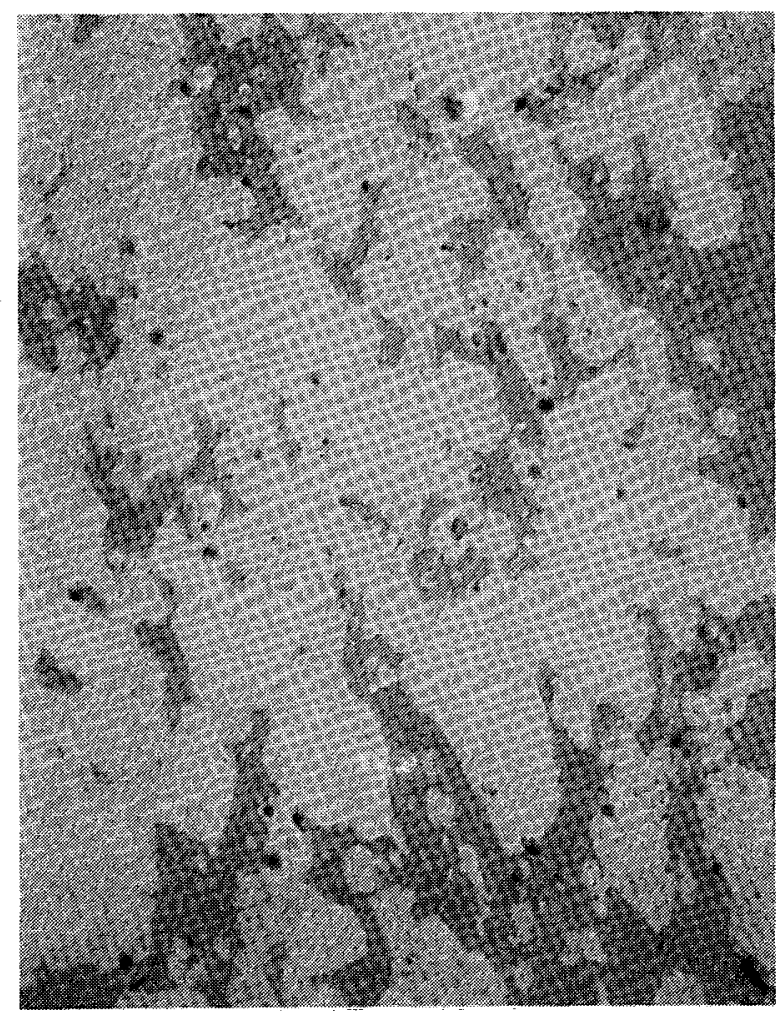

(b) Fuel at $200 x$

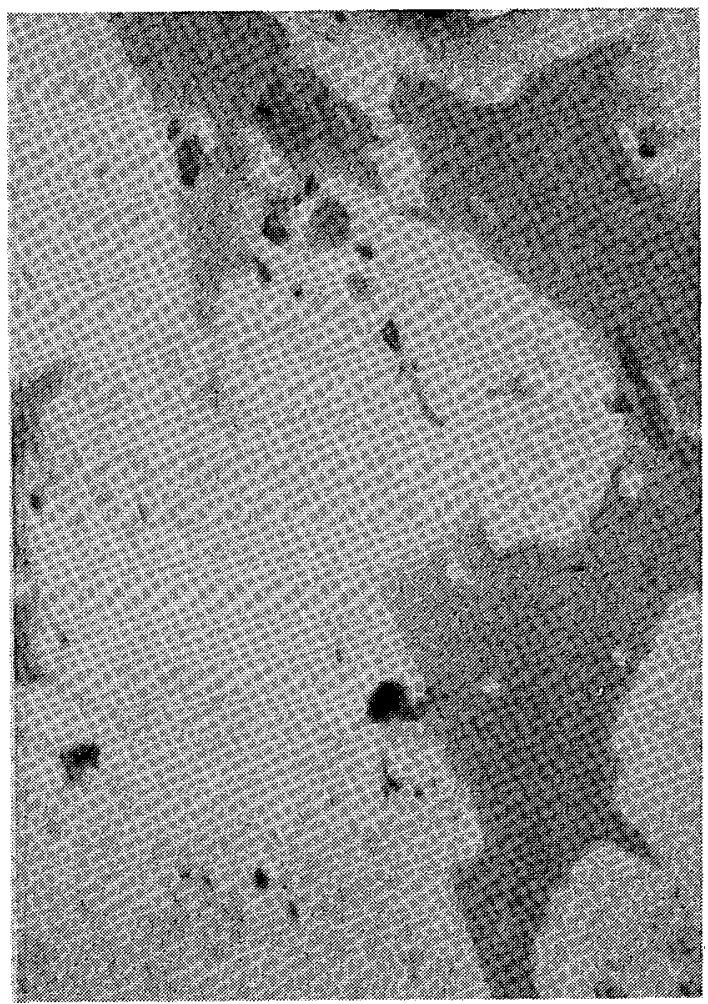

(c) Fuel at $1000 x$

Figure 16. SEM photographs of plate 006 , composition $50 \mathrm{vol \%} \mathrm{UAl}_{\mathrm{x}}$. 


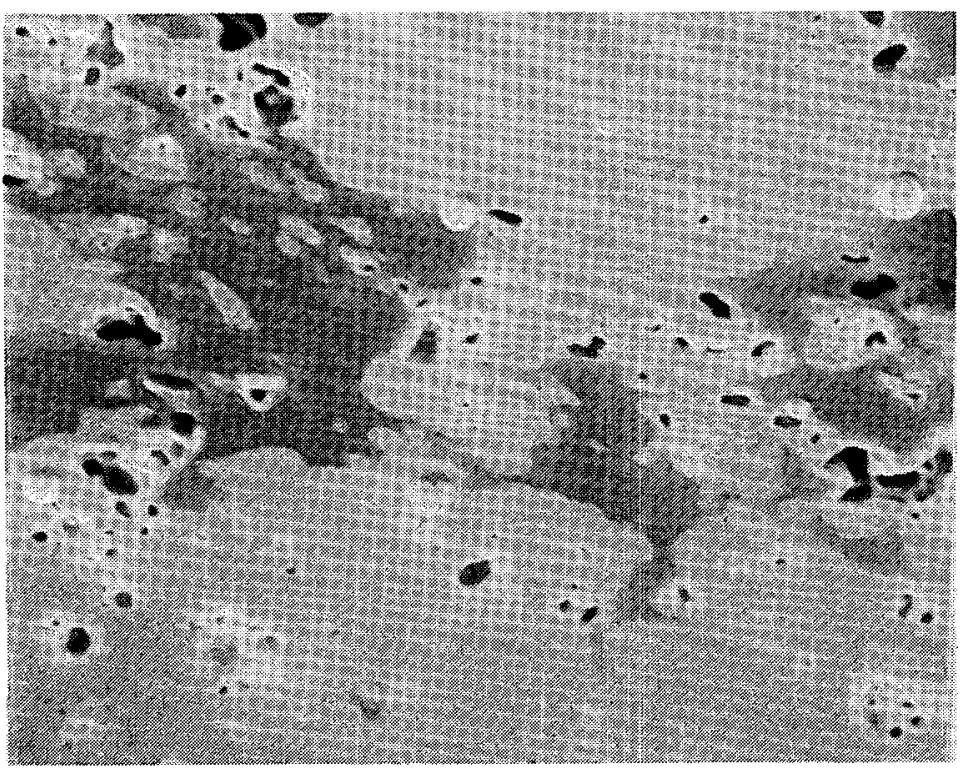

(a) Fuel at $500 x$

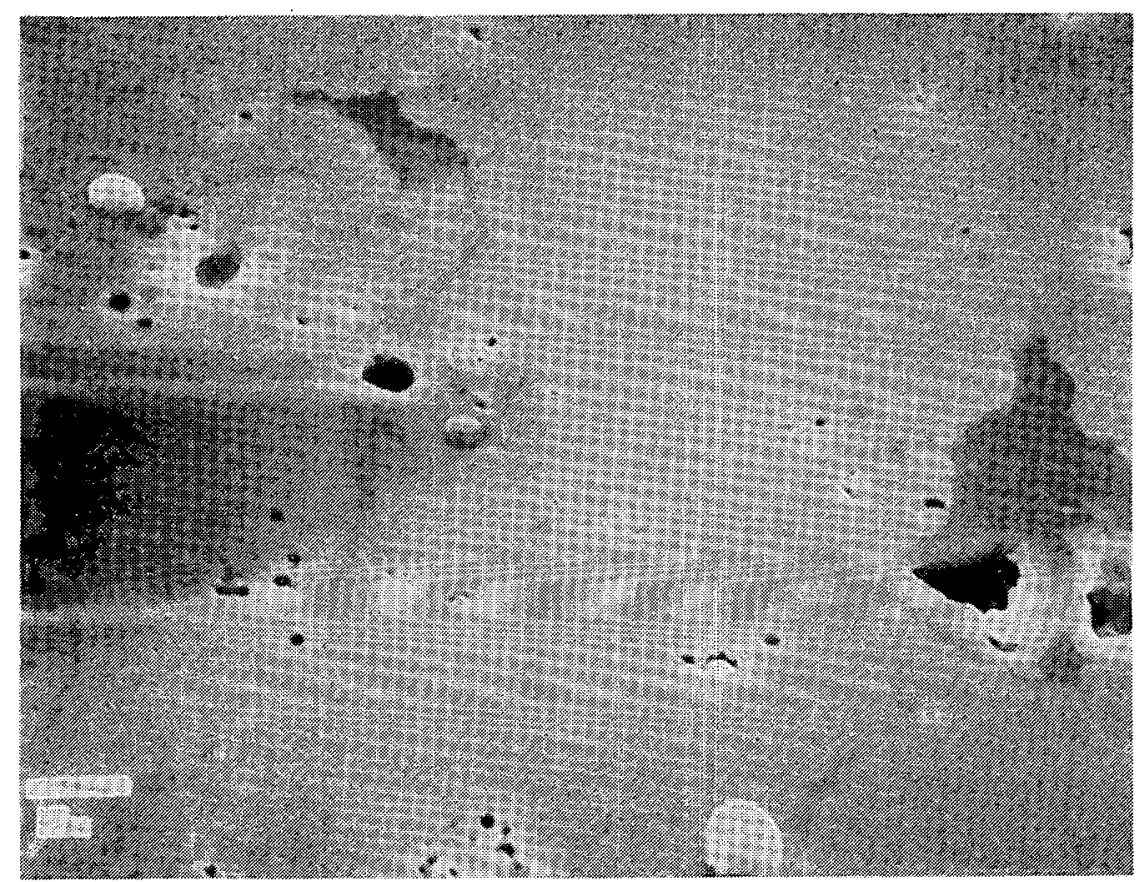

(b) Fuel at $1000 x$

Figure 17. SEM photographs of plate 013 , composition 50 vol\% $\mathrm{UAl}_{2}$. 


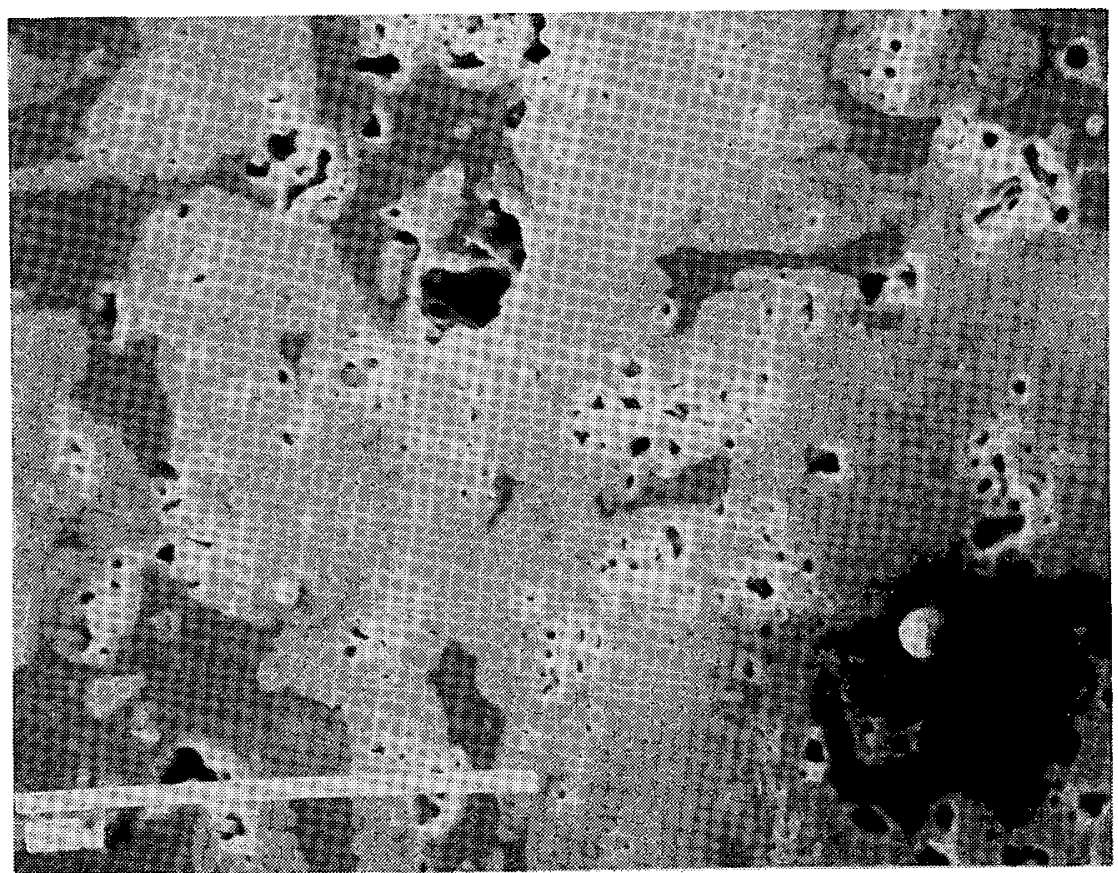

(a) Fuel at $500 x$

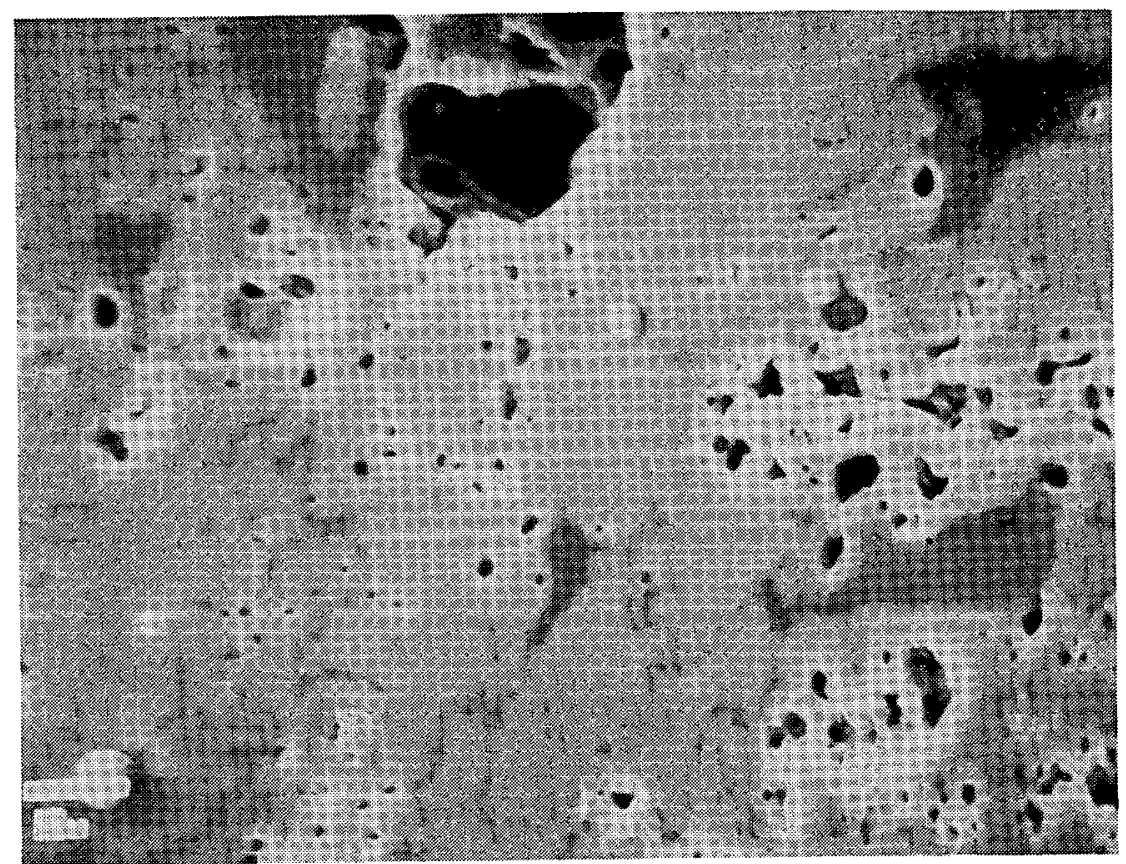

(b) Fuel at $1000 x$

Figure 18. SEM photographs of plate 028 , composition $45 \mathrm{vol} \% \mathrm{UAl}_{2}$. 


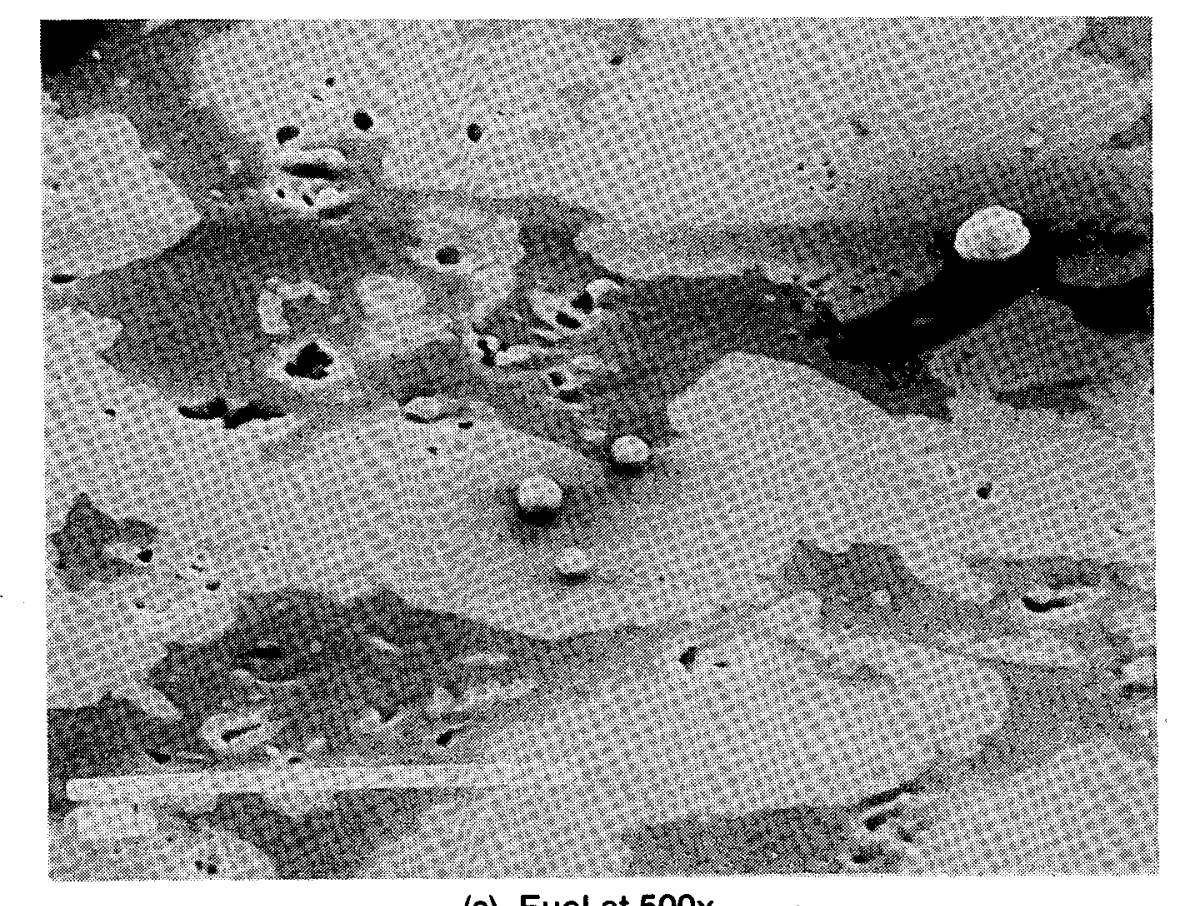

(a) Fuel at $500 x$

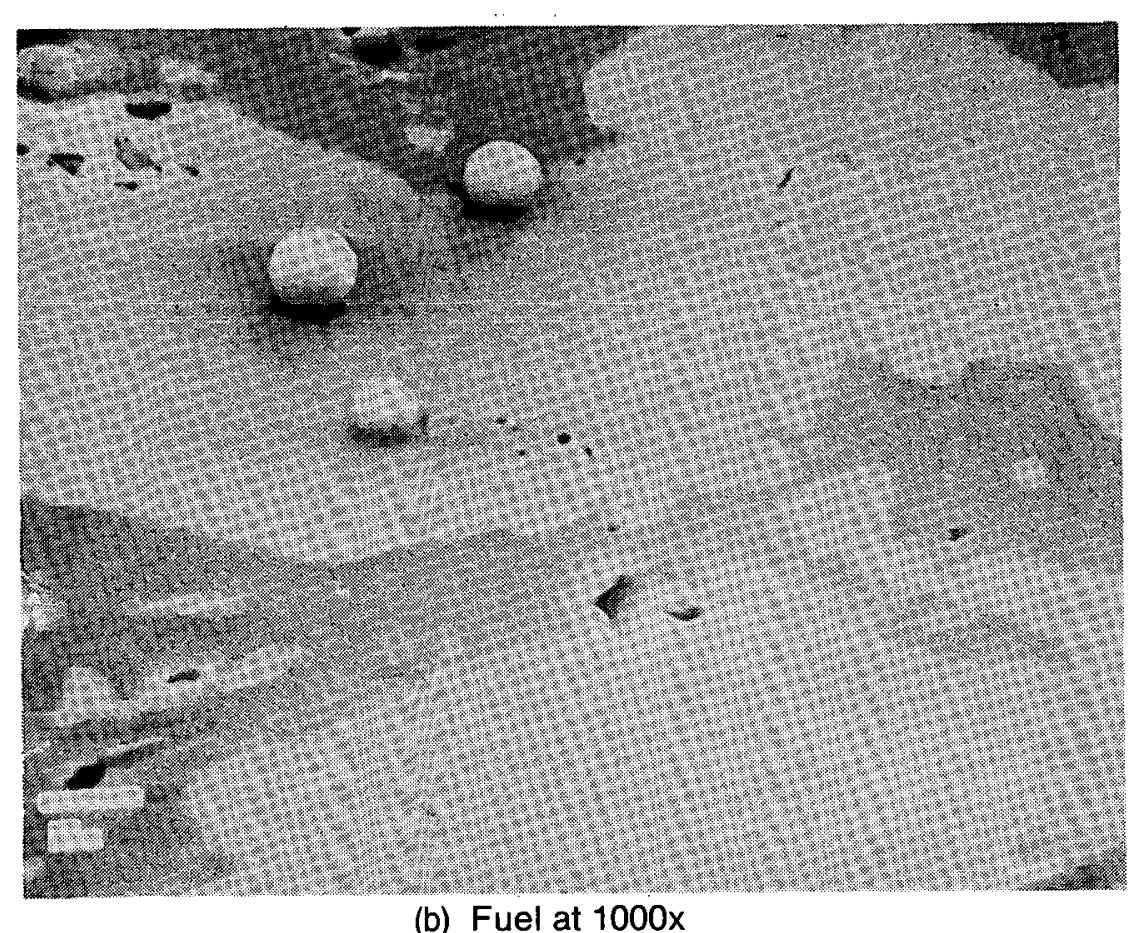

Figure 19. SEM photographs of plate 030 , composition $40 \mathrm{vol} \% \mathrm{UAl}_{2}$. 

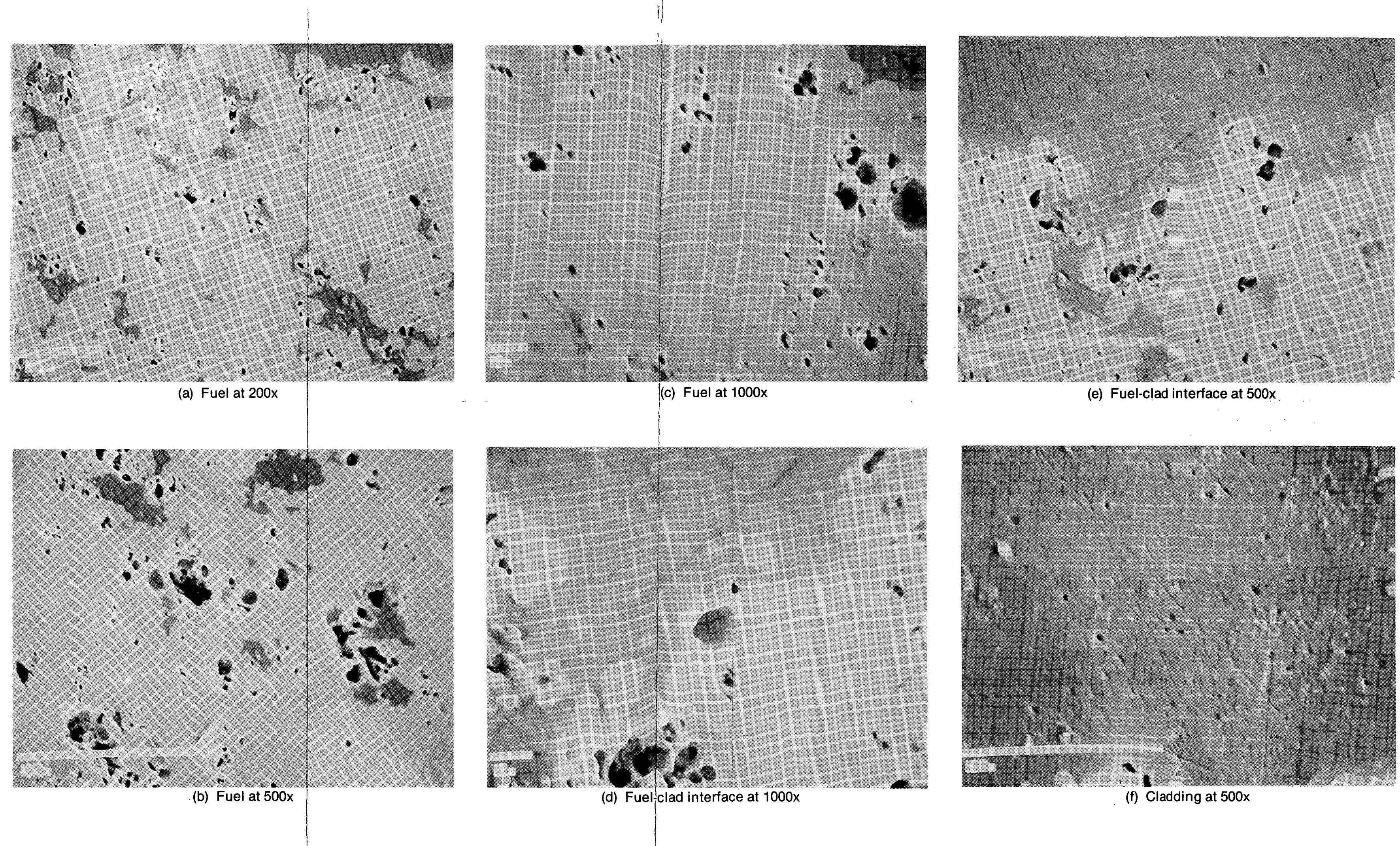

(e) Fuel-clad interface at 500x

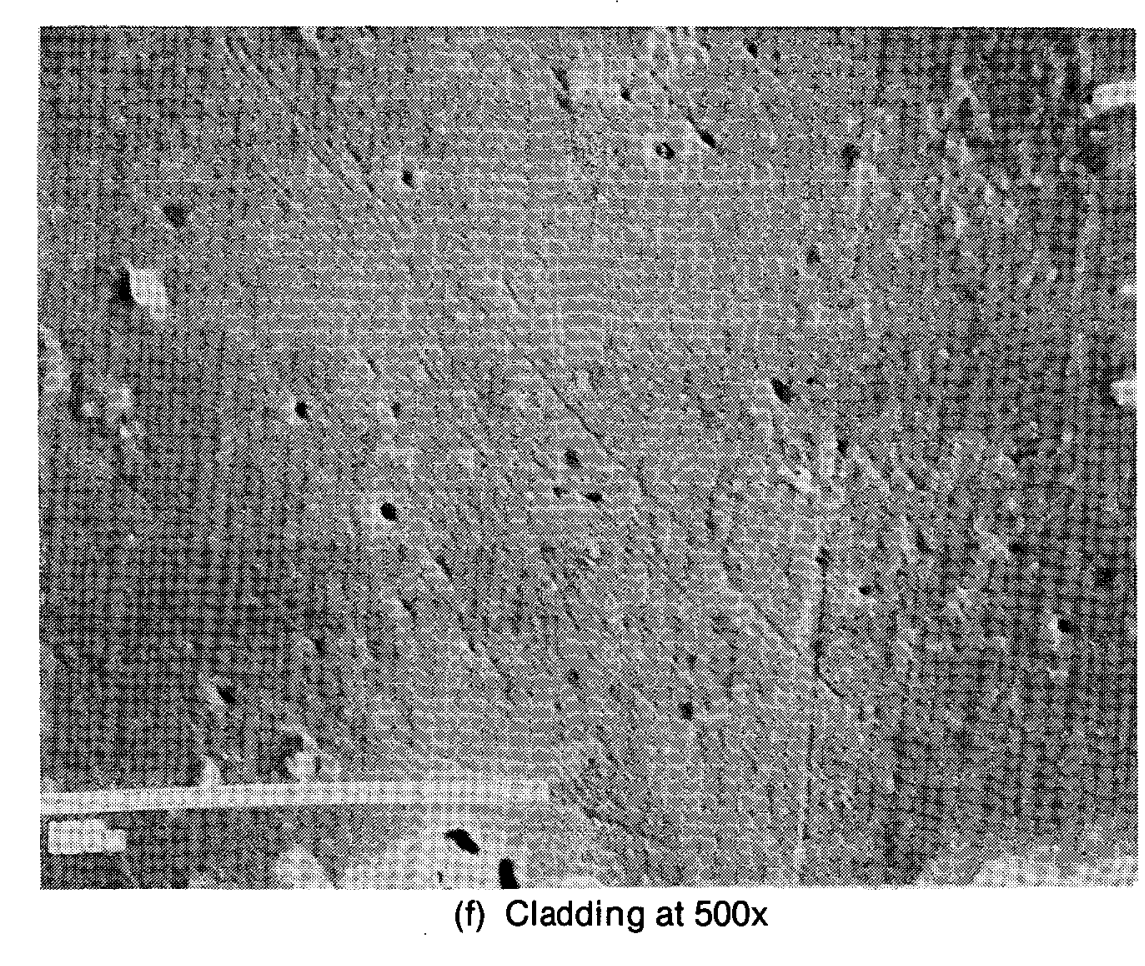

Figure 20. SEM photographs of plate 013 , acid etch, $50 \mathrm{vol}^{\prime} \mathrm{UAl}_{2}$. 


\begin{tabular}{|c|c|c|c|c|c|}
\hline \multirow{2}{*}{$\begin{array}{c}\text { Plate } \\
\text { Number }\end{array}$} & \multirow{2}{*}{$\begin{array}{c}\text { CSAP PDQ } \\
\text { Average Burnup } \\
\left(\mathrm{f} / \mathrm{cm}^{3} \times 10^{-21}\right) \\
\end{array}$} & \multirow{2}{*}{$\begin{array}{c}\text { Peak Fission }{ }^{\mathrm{a}} \\
\text { Density } \\
\left.\mathrm{cf} / \mathrm{cm}^{3} \times 10^{-21}\right)\end{array}$} & \multirow{2}{*}{$\begin{array}{c}\text { Punch } \\
\text { Fission } \\
\text { Density } \\
\text { Plus } \\
10 \% \\
\end{array}$} & \multicolumn{2}{|c|}{$\begin{array}{c}\text { Blister } \\
\text { Temperature }\end{array}$} \\
\hline & & & & K & ${ }^{\circ} \mathrm{C}$ \\
\hline 005 & 1.80 & 1.64 & 1.28 & 743 & 470 \\
\hline 006 & 2.30 & 2.17 & 1.73 & 743 & 470 \\
\hline 007 & 1.48 & 1.33 & 1.06 & 803 & 530 \\
\hline 013 & 2.98 & 3.00 & 2.02 & 743 & 470 \\
\hline $019^{b}$ & 2.13 & 1.94 & 1.49 & 833 & 560 \\
\hline 020 & 2.24 & 2.07 & 1.72 & 713 & 440 \\
\hline 022 & 1.82 & 1.95 & 1.22 & 773 & 500 \\
\hline 027 & 1.94 & 2.21 & 1.36 & 773 & 500 \\
\hline 028 & 2.61 & 2.71 & 1.96 & 773 & 500 \\
\hline 030 & 2.25 & 2.08 & 1.52 & 773 & 500 \\
\hline $032^{\mathrm{b}}$ & 2.14 & 1.98 & 1.49 & 833 & 560 \\
\hline 033 & 2.00 & 1.66 & 1.42 & 773 & 500 \\
\hline
\end{tabular}
a. Table 13.
b. Did not blister.

blister temperatures are given in Table 8. For a burnup of about $2 \times 10^{21} \mathrm{f} / \mathrm{cm}^{3}$, the blister temperature is greater than $743 \mathrm{~K}\left(470^{\circ} \mathrm{C}\right)$ for all the plates except No. 020, which was determined as $713 \mathrm{~K}$ $\left(440^{\circ} \mathrm{C}\right)$. For the twelve plates, the blister temperature is not strongly dependent upon the burnup as seen in Table 8 and Figure 21. The linear least squares analysis of the blister temperatures, in terms of the CSAP PDQ average burnup, gives the line indicated in Figure 21. Photographs of the blister samples are shown in Figures 22(a) through (f) for the 50 vol\% composition, and Figure 23(a) through (f) for the 45 and $40 \mathrm{vol} \% \mathrm{UAl}_{2}$. The average of blister temperatures for the three plates of $\mathrm{UAl}_{3}$ composition was lower $(763 \mathrm{~K})$ than for the nine plates of $\mathrm{UAl}_{2}$ composition $(776 \mathrm{~K})$.

The linear least squares regression analysis of the blister temperatures $(T)$ in degrees $K$, as a function of burnup (B), in units of $10^{21} \mathrm{f} / \mathrm{cm}^{3}$, (Table 8) gives the equation,

$\mathrm{T}=832-27.4 \mathrm{~B}$

where the correlation coefficient $(r)$ is 0.3 . Examination by regression analysis of the punch fission density plus $10 \%$ was slightly better where $\mathrm{r}=0.38$ and $\mathrm{T}=845-47.1(\mathrm{~B})$. This value of 0.3 (or 0.38 ) indicates a poor correlation, so that the dependency of the blister temperature $(T)$ on the burnup is not very strong. The linear least squares regression analysis was also evaluated for the peak burnup, since bubbles might be expected in the region of peak burnup. This correlation was not any better with $\mathrm{r}=0.3$.

Two of the plates of $\mathrm{UAl}_{2}$ composition did not blister at the end point test temperature, which is selected to prevent melting of the aluminum. One of the plates [No. 019-Figure 22(e)] is from the composition 50 vol\% $\mathrm{UAl}_{2}$, and the other [plate No. 032-Figure 23(e)] is from the composition 40 vol\% $\mathrm{UAl}_{2}$. These two plates did not have the lowest burnup. Plate No. 019 had an average burnup of $2.13 \times 10^{21} \mathrm{f} / \mathrm{cm}^{3}$, and plate No. 032 had an average burnup of $2.14 \times 10^{21} \mathrm{f} / \mathrm{cm}^{3}$. The plate with the lowest average burnup (No. 007) of $1.48 \times 10^{21} \mathrm{f} / \mathrm{cm}^{3}$ blistered at a temperature $30 \mathrm{~K}$ less than No. 019 and. 032 . One expects the peak burnup, which would give the maximum fission products, to drive the blister temperature. However, 


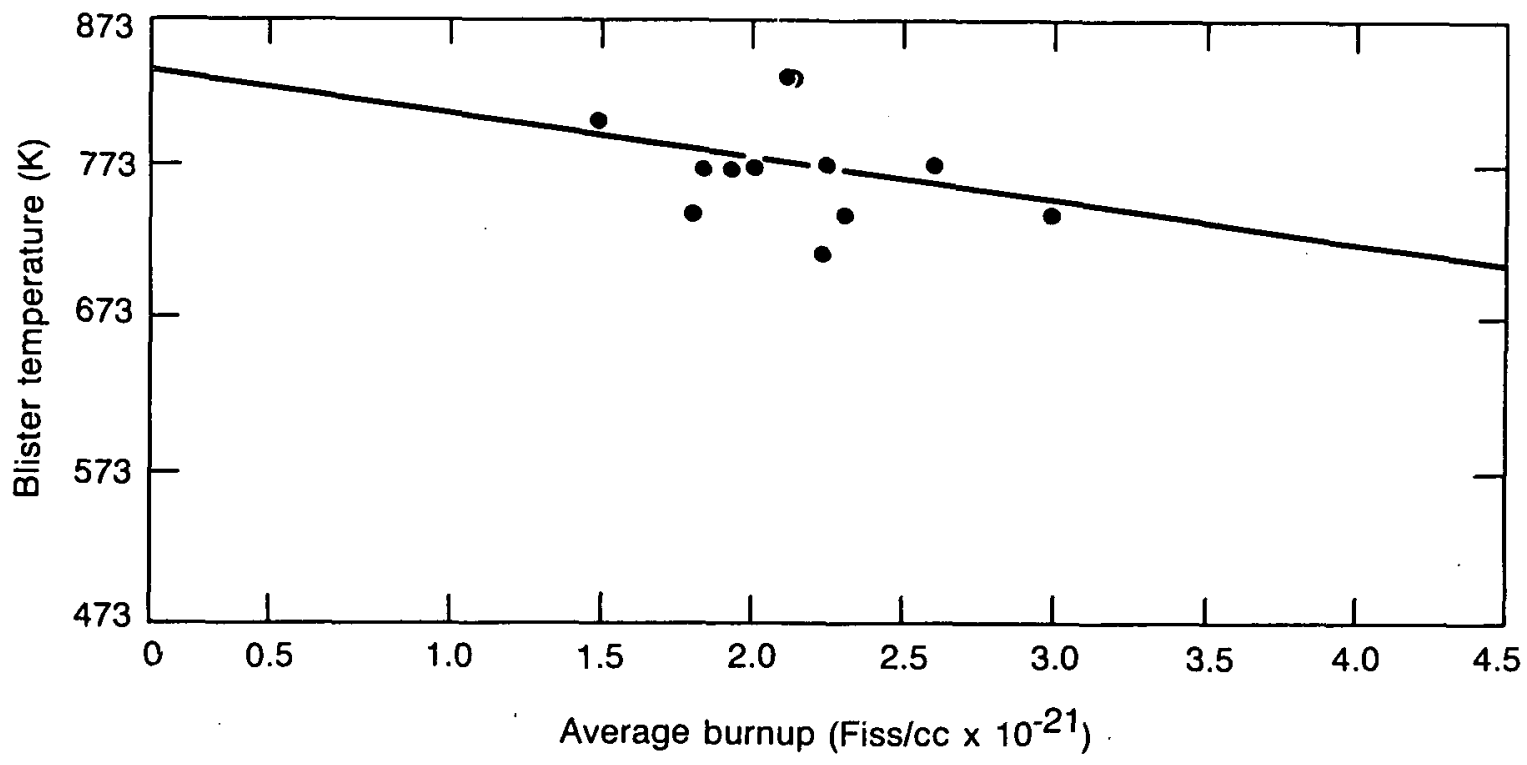

66688

Figure 21. Blister temperature as a function of the burnup.

it is noticed that the plates blister in the center, a region of lower burnup but lower strain constraint.

It is significant that the high fuel loading 50 vol\% $\mathrm{UAl}_{2}$, even at the highest burnup, does not blister at a lower temperature than the $50 \mathrm{vol \%}$ $\mathrm{UAl}_{3}$. It is also significant that the high fuel loading $\mathrm{UAl}_{2}$ or $\mathrm{UAl}_{3}(50 \mathrm{vol} \%)$ plates blister at temperatures comparable with normally loaded plates presently in use. ${ }^{9}$

\subsection{Pit Replication}

Replication was done on the 15 plates that were not to be included in the destruct tests. All 27 plates were examined after oxide removal on the hot cell periscope and pictures were taken of pit regions. On 15 plates, as each pit region was identified, a ring ( 1 in. diameter by $1 / 2$ in. high) was laid in place and filled with silicone rubber (either Dow Corning 3110 or G.E. RTV 60), The 12 plates used for destruct tests were not replicated to eliminate the need for cleanup on these plates. On the 30 sides of the 15 plates, 45 pit regions were identified and replicated. Pit regions were identified on all but 6 of the 30 sides. The pit regions on the 12 destruct plates looked similar to those replicated, except that the largest pits appeared to be on those plates to be replicated (specifically plates 004, 015, and 031), Figure 24 (a) through (d).

After the replicas had set up (about $16 \mathrm{hr}$ ), they were removed from the plate surface, ultrasonically cleaned, and coated with gold in a bell jar to increase the contrast. The replica on plate No. 025 tore off, so no pits were measured on this plate. Pit height on the replica (pits on the surface became peaks on the negative replica) was measured on a Unitron TMD-3721 microscope at 400X. The microscope featured a dial gauge with readout to $0.0001 \mathrm{in}$. on the fine focus and indication as to height or depth. This was very convenient for these measurements. The microscope stage also contained micrometer screws with readout to 0.0001 in. A turret objective provided lower magnification for survey and locating the pits.

Eighty-two pits were measured ranging in depths from $16.0 \mathrm{mil}(0.4 \mathrm{~mm})$ to $0.4 \mathrm{mil}(0.01 \mathrm{~mm})$, Table 9. The 16.0 mil deep pit was on the cladding edge, hence no fission product leakage occurred. It was also one of the plates (004) taken out during the fuel plate failure and stored in canal water for a long time (Table 9). ${ }^{12}$ The measurement of the pit diameter was about six times greater than the depth, a measurement useful in estimating the pit depth during inspection. The pit depths (height on the negative replica) are given in Table 9 for the 14 plates on which pits were measured (arranged in decreasing size). The next deepest pit $(7 \mathrm{mil})$ was also in the side plate cladding [Figure 24(d)]. Most of the pits were about $1 \mathrm{mil}$ deep (average $1.4 \pm 1.9$ for 82 pits measured), Table 9 .

Scanning electron microscope photographs from the replicas of the largest pit (plates No. 004, 16 mil deep and $40 \mathrm{mil}$ diameter) and 


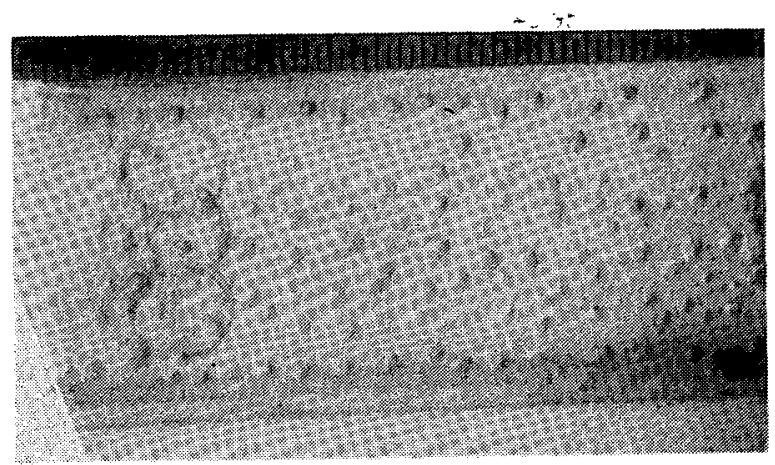

(a) Plate No. 005, blister T, $743 \mathrm{~K}$

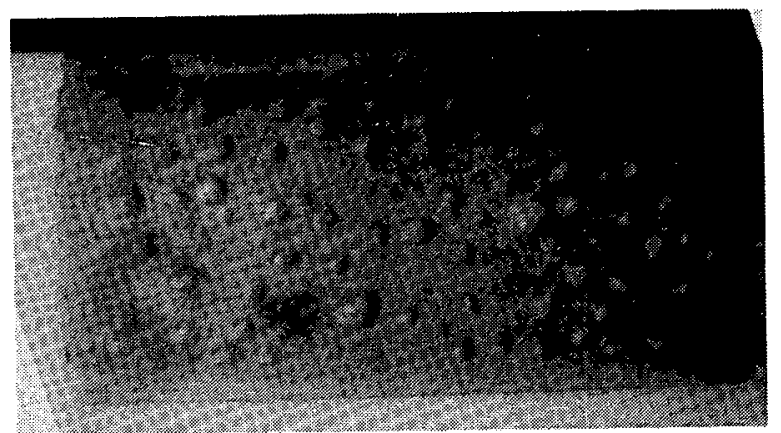

(c) Plate No. 007, blister T, $803 \mathrm{~K}$

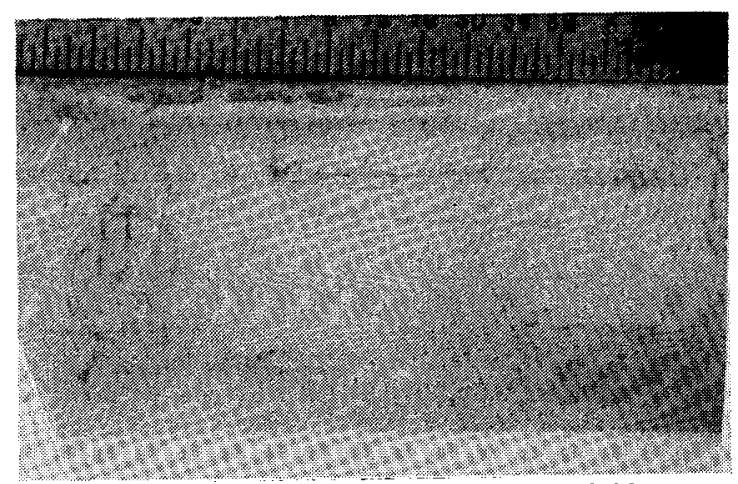

(e) Plate No. 019, blister T, $833 \mathrm{~K}$

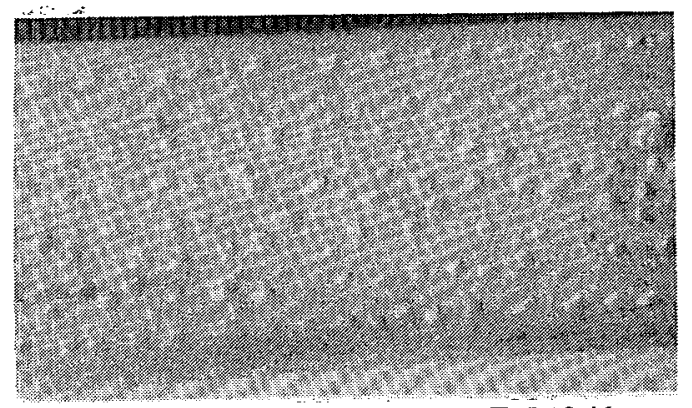

(b) Plate No. 006, blister T, $743 \mathrm{~K}$

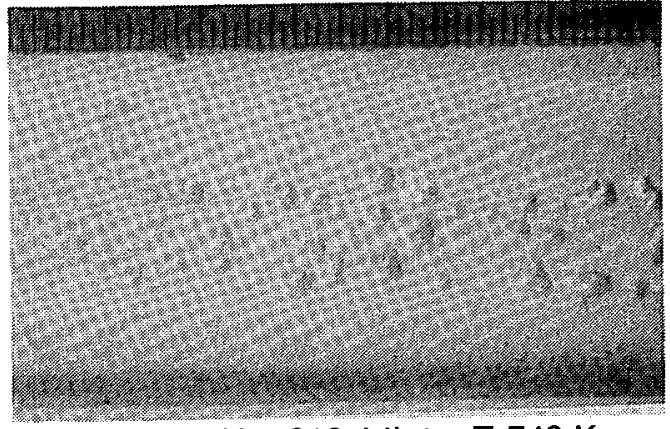

(d) Plate No. 013, blister T, $743 \mathrm{~K}$

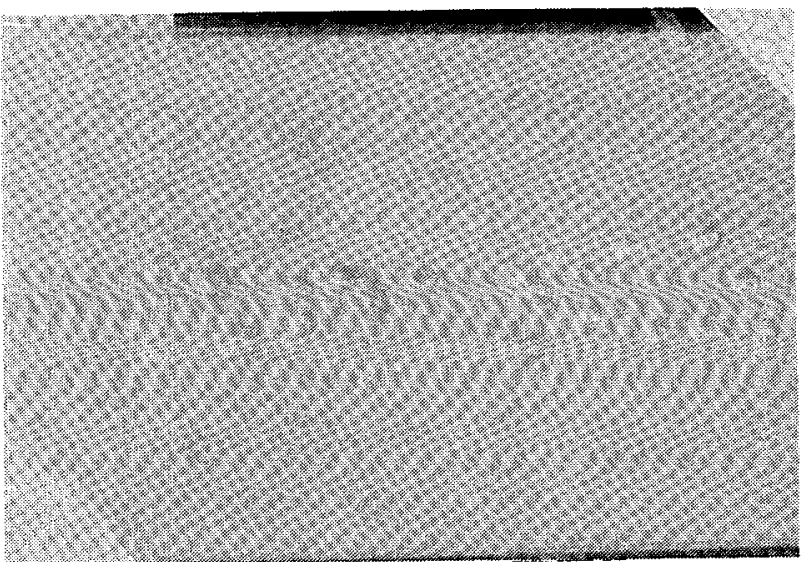

(f) Plate No. 020, blister T, $713 \mathrm{~K}$

Figure 22. Photographs of blister samples from 50 vol\% $\mathrm{UAl}_{2}$ and $\mathrm{UAl}_{3}$. 


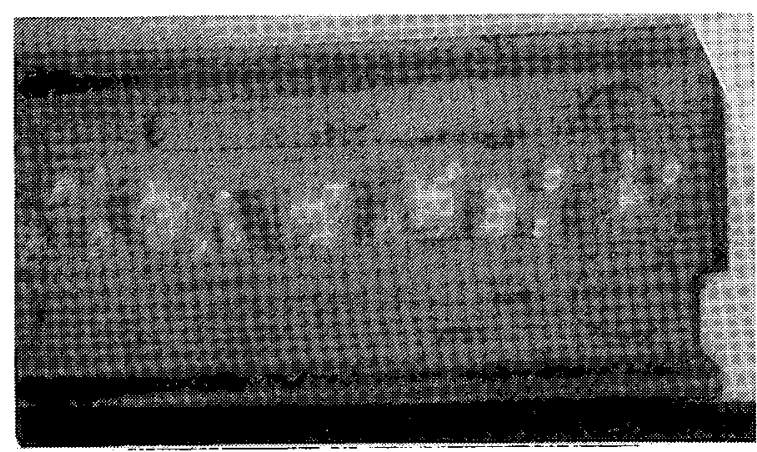

(a) Plate No. 022, blister T, $773 \mathrm{~K}$

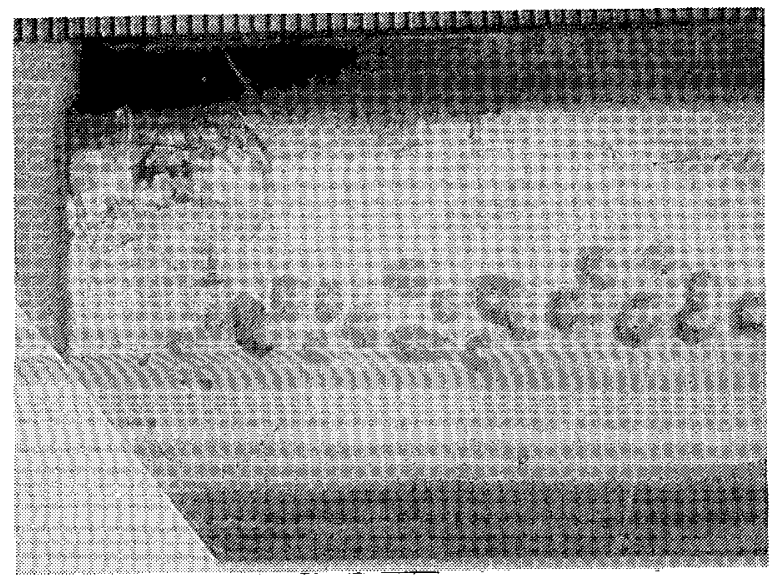

(c) Plate No. 028, blister T, $773 \mathrm{~K}$

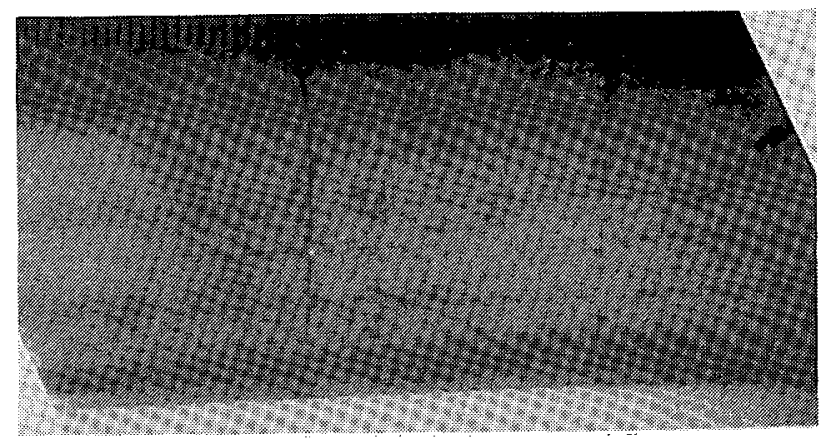

(e) Plate No. 032, blister T, $833 \mathrm{~K}$

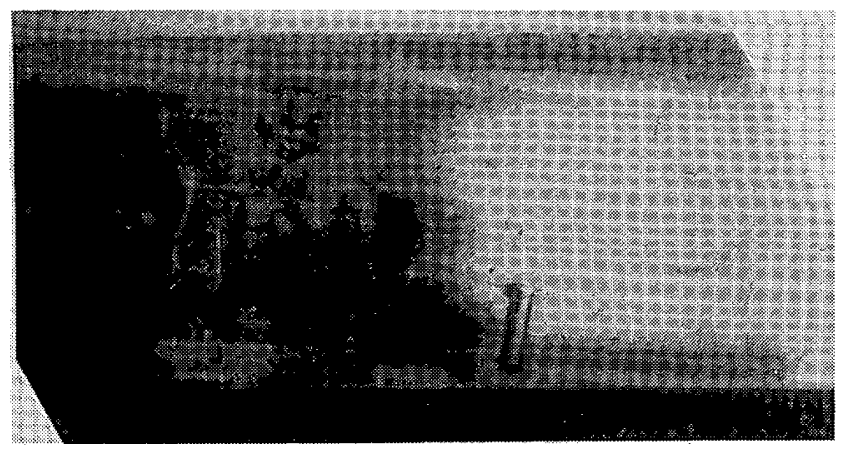

(b) Plate No. 027, blister T, $773 \mathrm{~K}$

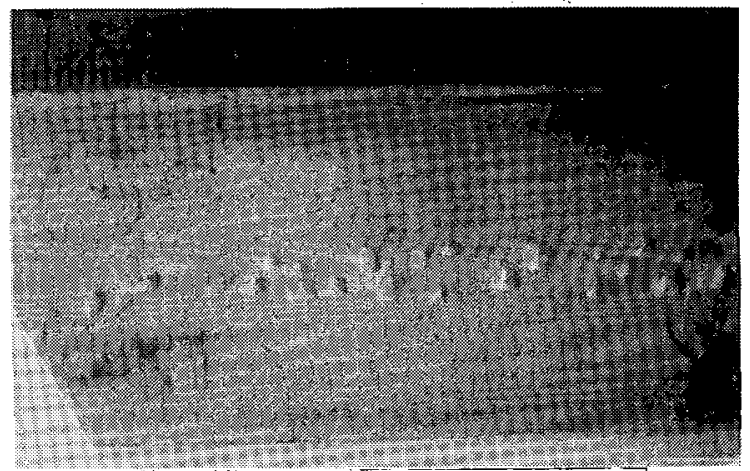

(d) Plate No. 030, blister T, $773 \mathrm{~K}$

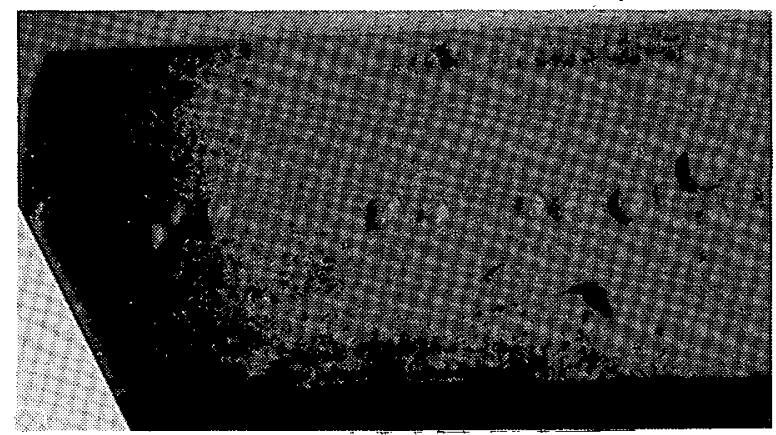

(f) Plate No. 033, blister T, $773 \mathrm{~K}$

Figure 23. Photographs of blister samples from 45 vol $\%$ and 40 vol $\% \mathrm{UAl}_{2}$. 


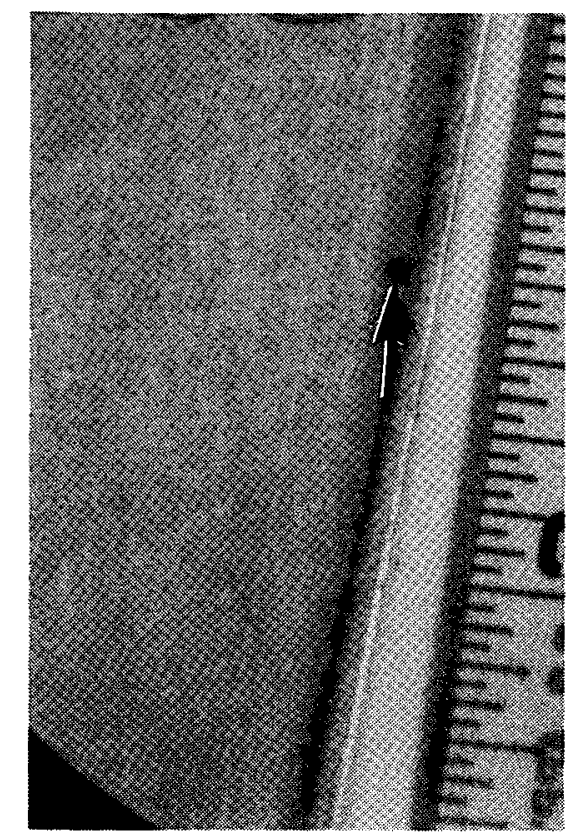

(a) Plate No. 004, 16 mil deep pit

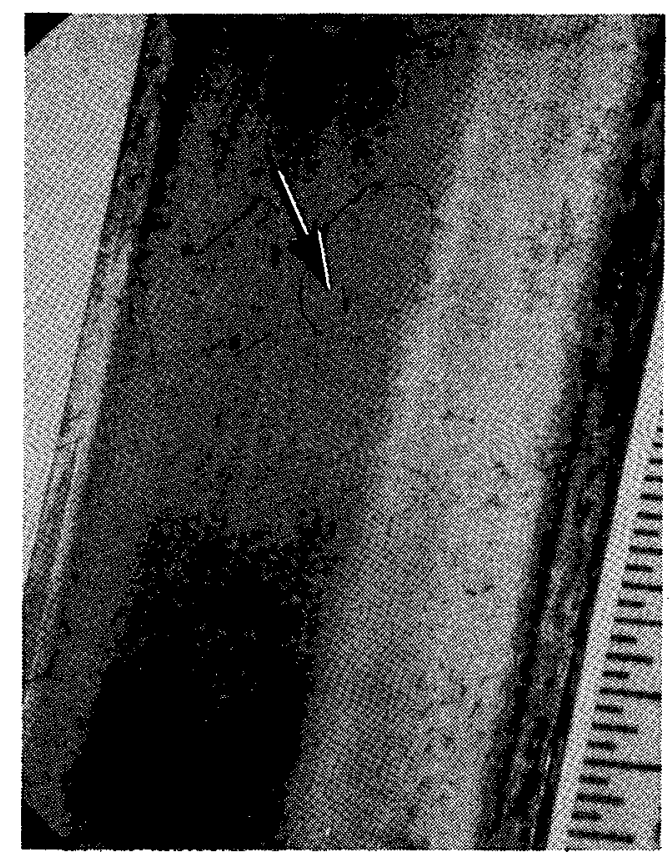

(c) Plate No. 015, 1.5 mil deep pit

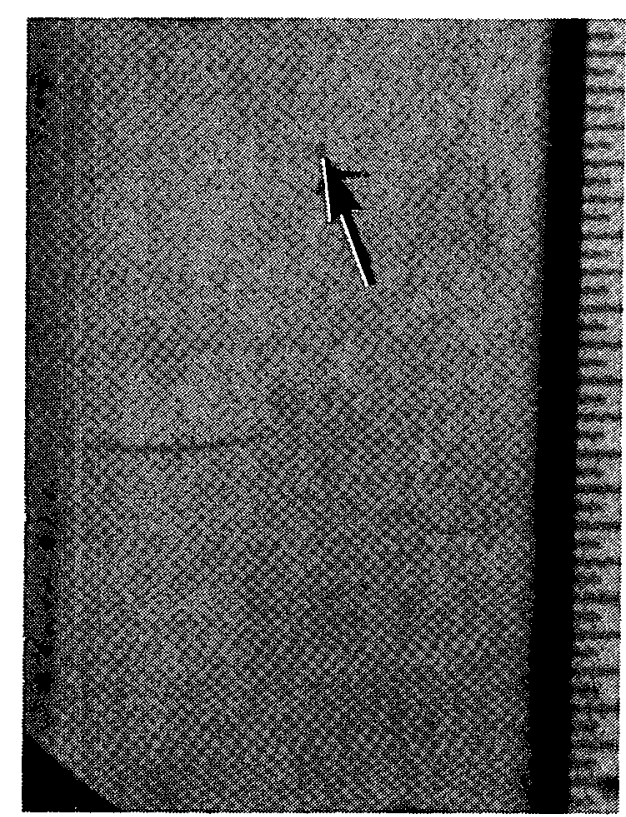

(b) Plate No. 004, 2 mil deep pit

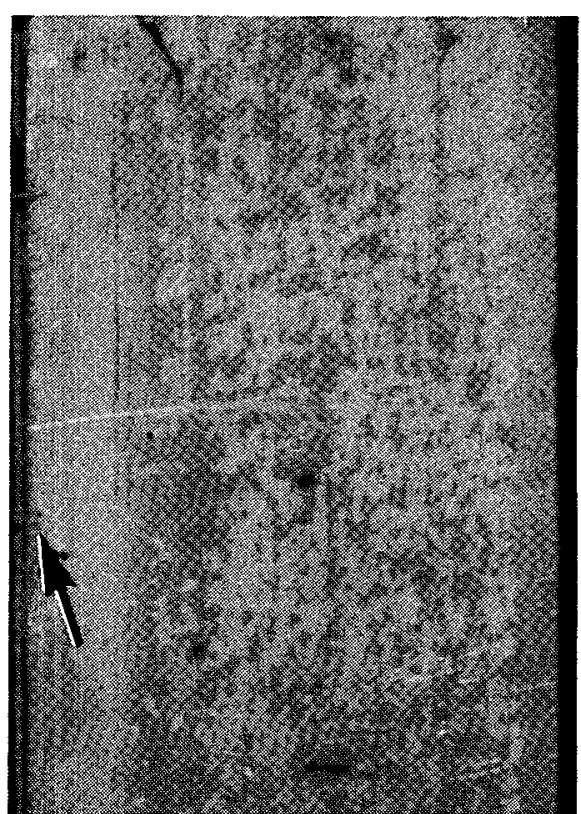

(d) Plate No. 031, 7.0 mil deep pit

Figure 24. Typical photographs of replica areas on oxide stripped plates. 
Table 9. Measured pit depth and calculated maximum total pitting corrosion

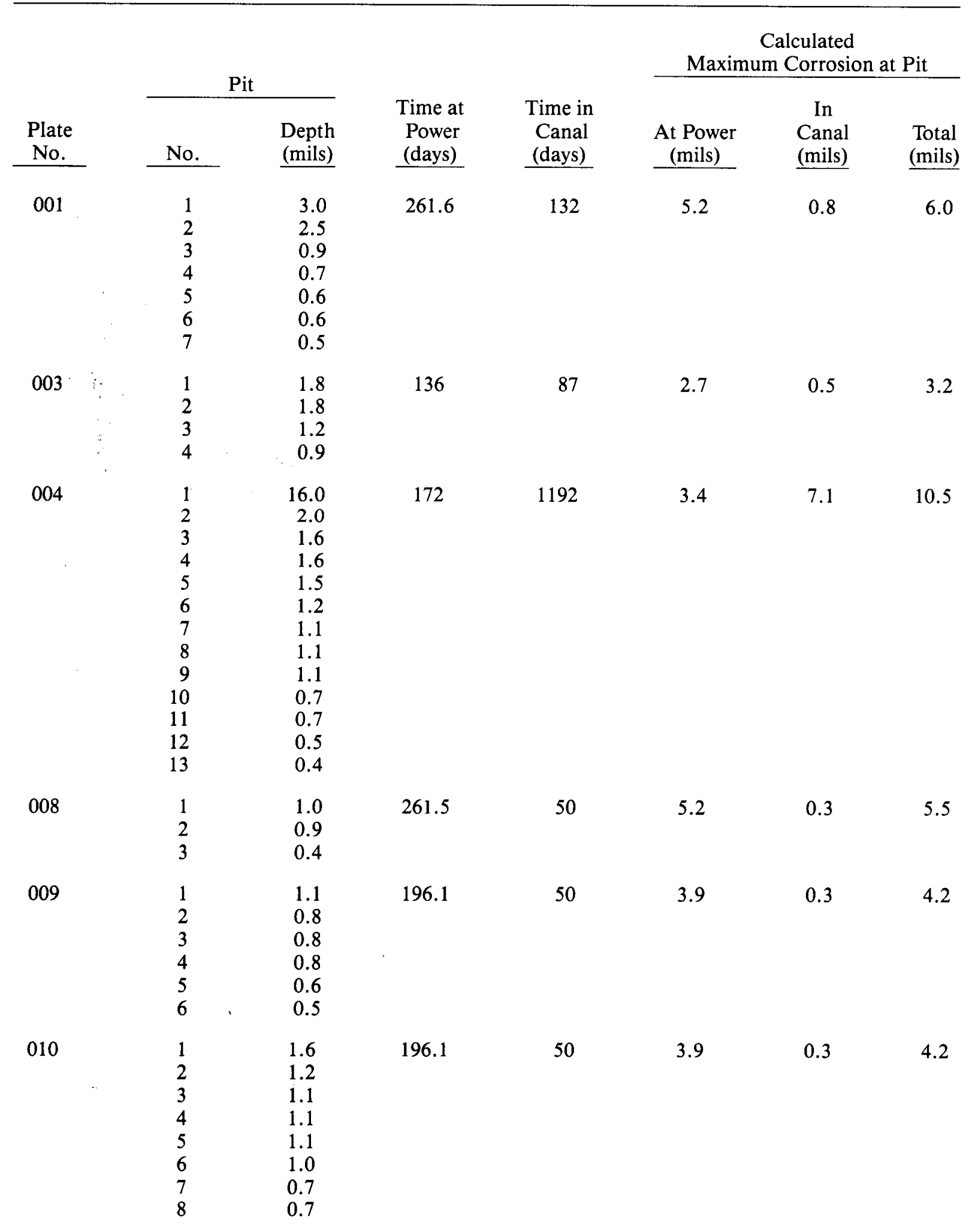


Table 9. (continued)

\begin{tabular}{|c|c|c|c|c|c|c|c|}
\hline \multirow[b]{2}{*}{$\begin{array}{l}\text { Plate } \\
\text { No. }\end{array}$} & \multicolumn{2}{|c|}{ Pit } & \multirow[b]{2}{*}{$\begin{array}{c}\begin{array}{c}\text { Time at } \\
\text { Power } \\
\text { (days) }\end{array} \\
\end{array}$} & \multirow[b]{2}{*}{$\begin{array}{c}\text { Time in } \\
\text { Canal } \\
\text { (days) } \\
\end{array}$} & \multicolumn{3}{|c|}{$\begin{array}{c}\text { Calculated } \\
\text { Maximum Corrosion at Pit }\end{array}$} \\
\hline & No. & $\begin{array}{l}\text { Depth } \\
\text { (mils) }\end{array}$ & & & $\begin{array}{l}\text { At Power } \\
\text { (mils) }\end{array}$ & $\begin{array}{c}\text { In } \\
\text { Canal } \\
\text { (mils) }\end{array}$ & $\begin{array}{r}\text { Total } \\
\text { (mils) } \\
\end{array}$ \\
\hline 015 & $\begin{array}{l}1 \\
2 \\
3 \\
4\end{array}$ & $\begin{array}{l}1.5 \\
1.5 \\
1.1 \\
1.1\end{array}$ & 136 & 877 & 2.7 & 5.2 & 7.9 \\
\hline 017 & $\begin{array}{l}1 \\
2 \\
3 \\
4\end{array}$ & $\begin{array}{l}0.8 \\
0.8 \\
0.8 \\
0.7\end{array}$ & 172 & 1192 & 3.4 & 7.1 & 10.5 \\
\hline 024 & $\begin{array}{l}1 \\
2 \\
3\end{array}$ & $\begin{array}{l}1.0 \\
1.0 \\
0.9\end{array}$ & 172 & 1192 & 3.4 & 7.1 & 10.5 \\
\hline 026 & $\begin{array}{l}1 \\
2 \\
3 \\
4 \\
5\end{array}$ & $\begin{array}{l}1.5 \\
1.5 \\
1.1 \\
0.9 \\
0.9\end{array}$ & 173 & 521 & 3.4 & 7.1 & 6.5 \\
\hline 029 & $\begin{array}{l}1 \\
2 \\
3 \\
4 \\
5\end{array}$ & $\begin{array}{l}1.4 \\
1.3 \\
0.6 \\
0.5 \\
0.4\end{array}$ & 172 & 1192 & 3.4 & 7.1 & 10.5 \\
\hline 031 & $\begin{array}{l}1 \\
2 \\
3 \\
4 \\
5 \\
6 \\
7\end{array}$ & $\begin{array}{l}7.0 \\
4.5 \\
1.6 \\
1.1 \\
0.6 \\
0.5 \\
0.5\end{array}$ & 212.7 & 474 & 4.2 & 2.8 & 7.0 \\
\hline 034 & 1 & 1.0 & 333.9 & 50 & 6.6 & 0.3 & 6.9 \\
\hline 036 & $\begin{array}{r}1 \\
2 \\
3 \\
4 \\
5 \\
6 \\
7 \\
8 \\
9 \\
10 \\
11 \\
12\end{array}$ & $\begin{array}{l}2.0 \\
1.9 \\
1.4 \\
1.4 \\
1.2 \\
1.2 \\
1.2 \\
1.1 \\
1.1 \\
0.8 \\
0.8 \\
0.5\end{array}$ & 72.4 & 379 & 1.4 & 2.3 & 3.7 \\
\hline
\end{tabular}


representative pits (plate No. 010 about 1 mil deep and 4 mil diameter) are shown in Figure 25 (a) and (b).

\subsection{Pitting Corrosion Rate}

Metal penetration can be expressed in terms of the maximum pit depth and the average of the 10 deepest pits. For the 14 plates, the 10 deepest pits include one that would have penetrated the cladding had it not been in the side plate area. The average of the ten deepest pits (Table 9) is $0.11 \mathrm{~mm}$ ( $4.3 \mathrm{mil}$ ). The pitting factor is determined from weight loss, defined as the ratio of the deepest metal penetration to the average metal penetration. The ratio of the maximum pit depth to the average pit depth gives an approximation of the pitting factor. The ratio is 3.8. A pitting factor of one represents uniform corrosion. The larger the pitting factor, the greater the probability of failure by pitting.

The maximum total pitting corrosion was calculated for the 27 plates (including the 14 plates given in Table 9) for the total time each plate was in the water (i.e., the time at power and the time in the canal). The calculation for the maximum pitting corrosion is based on the equation given 12 as

$\mathrm{CR}_{\max }=7.6 \times 10^{-24} \mathrm{~T}^{7.25}$ in./day

where $T=$ fuel plate surface temperature, $K$.

The fuel plate surface temperature at reactor power was taken as an average value for the calculation of $347 \mathrm{~K}$, and in the canal of $294 \mathrm{~K}$. The fuel plate surface temperature was determined from the oxide thickness at the end of the irradiation and the ATR startup equation ${ }^{17}$ given as

$X=10,344 \theta^{1.1} \exp \frac{-12,602}{{ }^{\circ} R}$

where

$$
\begin{aligned}
& \mathrm{X} \quad=\text { oxide thickness (mils) } \\
& \theta \quad=\text { hours in reactor. }
\end{aligned}
$$

The measured pitting corrosion of 14 plates is compared with that calculated for these plates at power and in the canal (Table 9). The calculated values for the maximum pitting corrosion of the other 13 plates, for which measured values were not obtained, were of similar magnitude. The highest maximum value was 14.6 mils for plate No. 006; the lowest maximum value was 6.6 mils for plate No. 033. Thus, the calculated value for the maximum total pitting corrosion by Equation 1 does approximate the measured value. Comparison of the calculated maximum pitting corrosion of 10.5 mils, with the measured value of 16 mils for plate No. 004, indicates that the equation for the maximum pitting corrosion rate is about right, since the plate in the canal would have been at a slightly higher temperature for part of the time. Considering the other measured values of the pit depths (Table 9) in light of the calculated maximum pit depth, indicates that the pit incubation time is not negligible or that most of the pits do not propagate at the maximum rate. Discussion of the pitting corrosion is given in Section 4.4.

\subsection{Gamma-Ray Spectroscopy}

The 12 fuel plates removed from the ATR reactor on June 23, 1985, were examined by gamma-ray spectrometry measurements at the TRA Hot Cell Facility. ${ }^{18}$ The purpose of the measurements was to determine the distribution of gamma-ray emitting fission product radionuclides in the fuel. These results will be combined with radiochemical analyses of samples taken from the fuel plates to determine the peak fuel burnup (fission density) in each plate. The measurement results for the positions from which the burnup punchings were taken are given in relative counts per second for each individual radionuclide in Table 10. The radionuclides identified are ${ }^{95} \mathrm{Zr},{ }^{103} \mathrm{Ru},{ }^{134} \mathrm{Cs},{ }^{137} \mathrm{Cs}$, and ${ }^{144} \mathrm{Ce}$ for each of the 12 plates. The counts per second for each radionuclide at the maximum, and the punching positions, are tabulated in Table 10. Also given in Table 10 is the average of 19 measurements of each radionuclide on each plate. Since no efficiency calibrations exist, quantitative activities and gamma-intensities are undetermined; therefore, the counts per second of one radionuclide are not related to another radionuclide. All the data were decay corrected to 6-23-85 at $2000 \mathrm{hr}$. The punching position point counts were taken at the 6.4 in. distance from the bottom of the fuel plate and at the axial centerline. The actual area viewed was 0.055 in. by 0.688 in. or 0.038 in. $^{2}$. Appendix A contains a copy of the gamma-ray spectroscopy report. ${ }^{18}$ Table 11 contains ratios of the maximum gamma counts per second in any position measured to that at which the burnup punching was taken. These ratios (maximum gamma counts per second of one area to that of the burnup punching) 


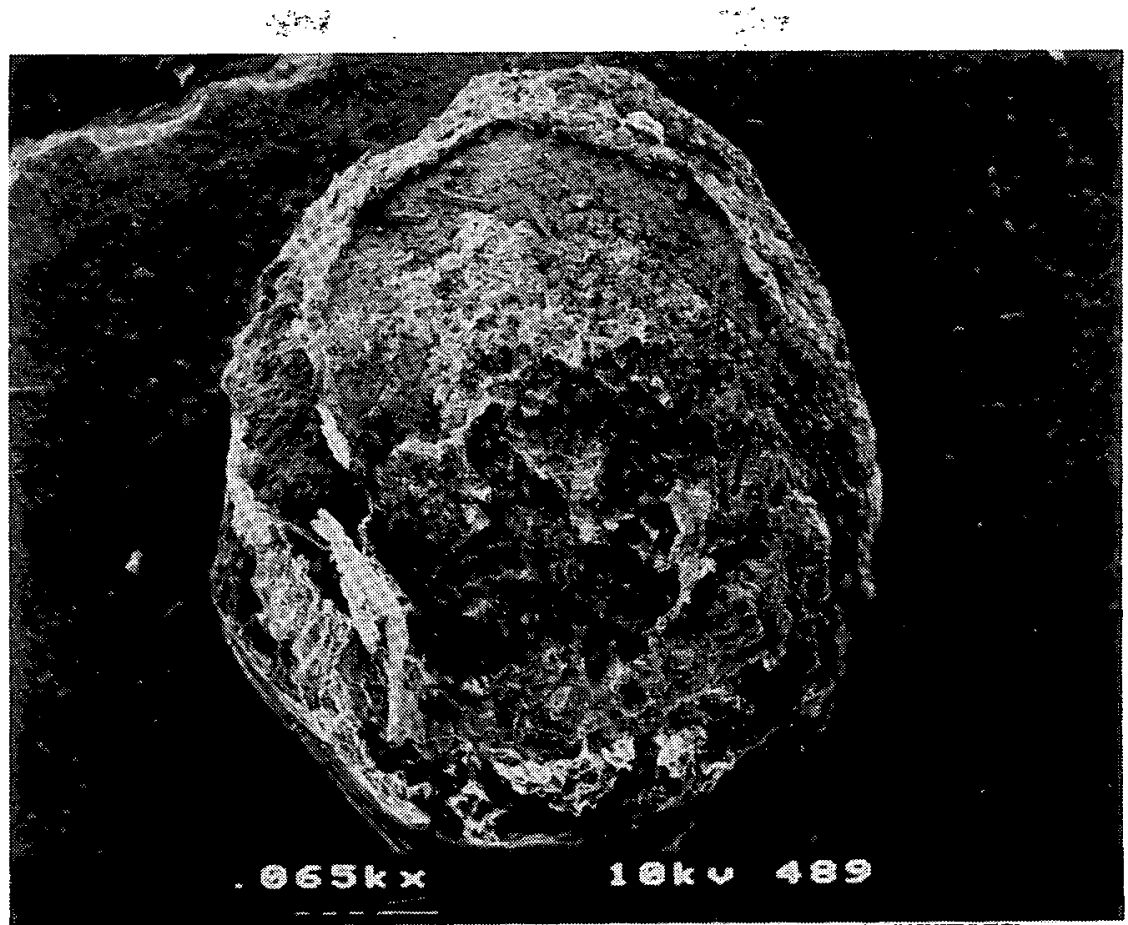

(a) Plate No. 004 largest pit, 16 mil deep in side cladding

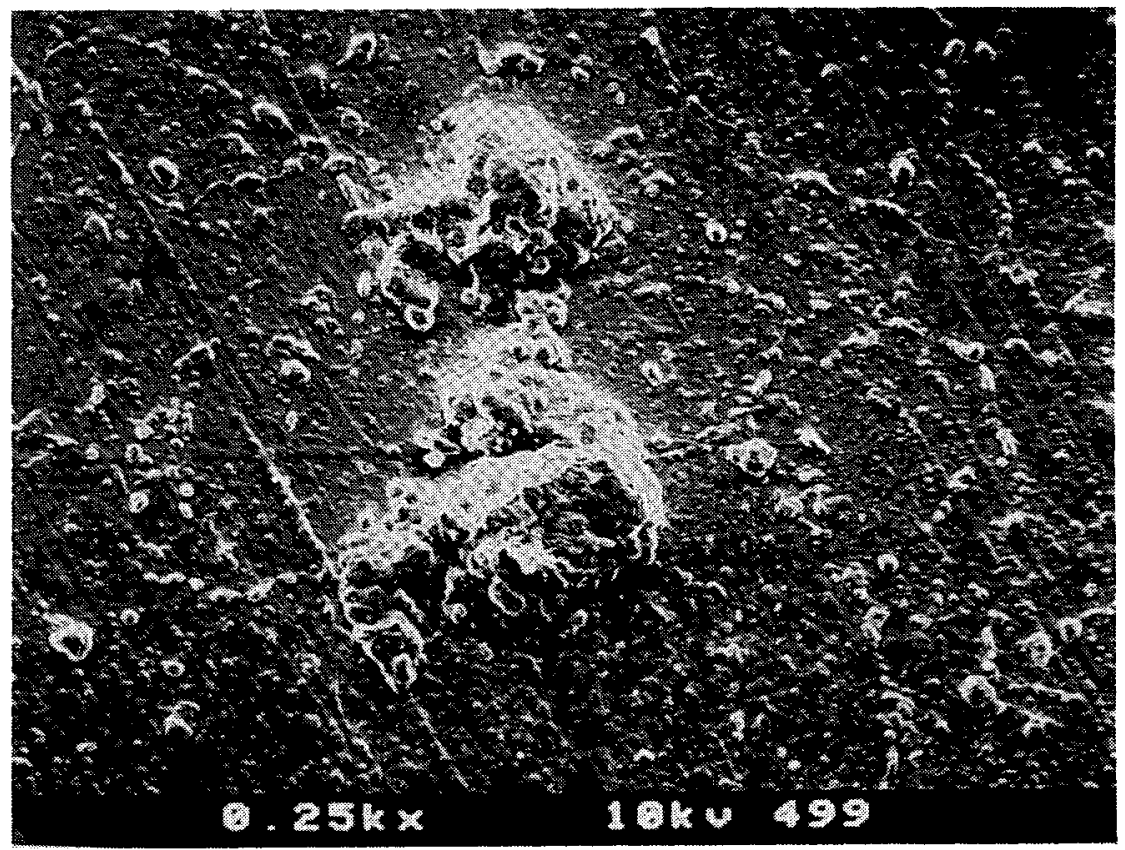

(b) Plate No. 010, 2 pits, depth about $1 \mathrm{mil}$

Figure 25. SEM photographs of two of the replicated pits. 
Table 10. Relative radionuclide activity of the twelve plates in counts per second for the maximum, average, and punching positions

\begin{tabular}{|c|c|c|c|c|c|c|c|c|c|c|c|c|c|c|c|}
\hline \multirow{2}{*}{$\begin{array}{c}\text { Plate } \\
\text { Number } \\
\end{array}$} & \multicolumn{3}{|c|}{${ }^{95} \mathrm{Zr}$} & \multicolumn{3}{|c|}{${ }^{103} \mathrm{Ru}$} & \multicolumn{3}{|c|}{${ }^{134} \mathrm{Cs}$} & \multicolumn{3}{|c|}{${ }^{137} \mathrm{Cs}$} & \multicolumn{3}{|c|}{${ }^{144} \mathrm{Ce}$} \\
\hline & Punch & Avg & $\underline{\operatorname{Max}}$ & Punch & Avg & $\operatorname{Max}$ & Punch & Avg & Max & Punch & Avg & $\underline{\text { Max }}$ & Punch & Avg & $\underline{\operatorname{Max}}$ \\
\hline 5 & 225 & 231 & 248 & 400 & 412 & 446 & 8.58 & 9.22 & 11.0 & 31.6 & 33.5 & 37.9 & 116 & 121 & 131 \\
\hline 6 & 325 & 337 & 365 & 458 & 473 & 512 & 21.6 & 23.5 & 27.0 & 44.0 & 46.9 & 52.7 & 230 & 242 & 268 \\
\hline 7 & 389 & 400 & 442 & 553 & 561 & 617 & 7.16 & 7.69 & 9.04 & 25.4 & 26.4 & 30.1 & 155 & 163 & 193 \\
\hline 13 & 33.1 & 35.0 & 39.7 & 9.1 & 10.2 & 12.3 & 18.6 & 20.2 & 27.6 & 48.9 & 51.6 & 62.8 & 155 & 163 & 193 \\
\hline 19 & 619 & 660 & 745 & 906 & 961 & 1072 & 11.4 & 12.4 & 14.9 & 35.0 & 38.8 & 43.3 & 346 & 378 & 427 \\
\hline 20 & 789 & 802 & 849 & 1153 & 1172 & 1234 & 15.4 & 16.3 & 18.6 & 44.4 & 46.2 & 50.8 & 443 & 460 & 497 \\
\hline 22 & 476 & 508 & 629 & 692 & 734 & 915 & 8.2 & 9.0 & 13.1 & 28.6 & 30.8 & 39.7 & 279 & 303 & 381 \\
\hline 27 & 32.7 & 35.3 & 43.5 & 10.3 & 10.3 & 12.8 & 8.13 & 9.0 & 13.2 & 29.7 & 32.3 & 41.9 & 143 & 155 & 199 \\
\hline 28 & 452 & 454 & 497 & 641 & 645 & 711 & 22.2 & 23.3 & 30.7 & 47.9 & 49.3 & 56.5 & 337 & 345 & 386 \\
\hline 30 & 389 & 455 & 533 & 542 & 624 & 737 & 13.0 & 14.7 & 17.6 & 33.1 & 39.0 & 44.5 & 305 & 352 & 408 \\
\hline 32 & 4.1 & 4.6 & 5.5 & - & - & - & 8.41 & 9.1 & 10.5 & 32.8 & 35.7 & 39.2 & 75.8 & 82.3 & 92.9 \\
\hline 33 & - & - & - & - & - & - & 5.56 & 6.0 & 6.49 & 31.9 & 34.0 & 36.8 & 48.7 & 51.3 & 56.1 \\
\hline
\end{tabular}

represent the measured burnup peaking that occurred in each plate. The plates in each composition group ( 50 vol\% $\mathrm{UAl}_{2}$, etc.) were placed in the I-hole fixture for the irradiation history as indicated in Appendix A, Table A-1 and Figure A-1. Positions $B$ and $D$, where the plate edge was toward the reactor core, generally produced higher peaking in one edge of these plates. The plates were moved about as seen in Table A-1, which tended to reduce this edge effect. The selection of the peaking factor from the gamma-scan data (to represent the maximum burnup for each plate) is complicated by the limited number of isotope counts on each plate, the relative size of the gamma-scan area, and a

Table 11. Ratios of isotopic maximum gamma counts per second to those of the burnup punching position

\begin{tabular}{|c|c|c|c|c|c|c|}
\hline \multirow{2}{*}{$\begin{array}{c}\text { Plate } \\
\text { Number }\end{array}$} & \multicolumn{5}{|c|}{ Ratios For Isotopes } & \multirow{2}{*}{$\begin{array}{l}\text { Maximum } \\
\text { Peaking } \\
\text { Factor }\end{array}$} \\
\hline & ${ }^{95} \mathrm{Zr}$ & ${ }^{103} \mathrm{Ru}$ & ${ }^{134} \mathrm{Cs}$ & ${ }^{137} \mathrm{Cs}$ & ${ }^{144} \mathrm{Ce}$ & \\
\hline 005 & 1.10 & 1.12 & 1.28 & 1.20 & 1.13 & 1.41 \\
\hline 006 & 1.12 & 1.12 & 1.25 & 1.20 & 1.17 & 1.38 \\
\hline 007 & 1.14 & 1.12 & 1.26 & 1.19 & 1.25 & 1.39 \\
\hline 013 & 1.20 & 1.35 & 1.48 & 1.28 & 1.25 & 1.63 \\
\hline 019 & 1.20 & 1.18 & 1.31 & 1.24 & 1.23 & 1.44 \\
\hline 020 & 1.08 & 1.07 & 1.21 & 1.14 & 1.12 & 1.33 \\
\hline 022 & 1.32 & 1.32 & 1.60 & 1.39 & 1.37 & 1.76 \\
\hline 027 & 1.33 & 1.24 & 1.62 & 1.41 & 1.39 & 1.78 \\
\hline 028 & 1.10 & 1.11 & 1.38 & 1.18 & 1.15 & 1.52 \\
\hline 030 & 1.37 & 1.36 & 1.35 & 1.34 & 1.34 & 1.51 \\
\hline 032 & 1.34 & - & 1.25 & 1.20 & 1.23 & 1.47 \\
\hline 033 & - & - & 1.17 & 1.15 & 1.15 & 1.29 \\
\hline
\end{tabular}

a. Maximum peaking factor is the maximum isotopic ratio for each plate plus $10 \%$. 
possible blister area. The limited number (19) of isotope counts on each plate may mean that the peak count was missed. The relative size of the gamma-scan collimator area $\left(0.038\right.$ in. $\left.^{2}\right)$ to a possible peaking (blister) area $\left(0.003\right.$ in. $\left.^{2}\right)$ may tend to level out (miss) the maximum counts. To accommodate these effects, the calculated PDQ average to minimum peaking factor was evaluated. The average to the minimum peaking was about $10 \%$, which was added to the maximum isotopic ratio for each plate to obtain an overall maximum peaking factor (Table 11).

\subsection{Radiochemical Analyses for Burnup}

The punchings for burnup analyses were taken $6.380 \mathrm{in}$. from the bottom of the plate and at the axial centerline. The punchings were 0.25 in. in diameter with an area of 0.049 in..$^{2}$. The punchings taken at the axial and horizontal centerline are in a region of uniform burnup, although it is a region of expected lowest burnup in each plate. Because of the uniformity of burnup expected in this centerline punching, and in order to limit program costs, this centerline punching was the one on which radiochemical analyses were done for burnup. Therefore, it is pointed out that (generally) any other region referred to, or examined, would have a higher burnup than that of the punching analyses. For this reason, in referring to a burnup of a region, the PDQ average or peak burnup is used. This peak burnup is the lowest burnup multiplied by the peaking factor from Table 11. This peak burnup is about the same as that of the PDQ average burnup calculated, which was used to guide the irradiation and determine plate removal at the end of irradiation (Section 2.1). The ratio of the average PDQ fission density to the minimum fission density is 1.1; hence, in Tables 1, 4, and 8, 10\% is added to the low fission density to obtain an average.

The burnup of each punching was obtained from the isotopic ratios (Table 12) by means of a computer program used for high enrichment test reactor fuels. 19 The irradiation history (Figure 1) was divided into sequential power factor intervals. Considering results from previous analyses ${ }^{19}$, and the 4 group ATR PDQ calculated flux in the homogenized fuel plate region inside the ELAF assembly, the capture to fission cross section, $\alpha$, was taken to be $\alpha=0.196 \pm 0.01$. The program iterates the data until it converges on an apparent fluence and the measured isotopic ratios, and prints out a final ${ }^{236} \mathrm{U} /{ }^{235} \mathrm{U}$ ratio. A number of checks were made on the calculational procedure and data, including: a change in $\alpha$ to the ATR core region; ${ }^{19}$ the gamma spectroscopy cesium 134, 137 results; and total uranium concentration in the punchings. These checks did not change the calculated burnup for the punching position (Table 13) significantly. For example, an $\alpha$ of 0.215 for the ATR core region 19 reduced the burnup by about $6 \%$, which is to be expected because of the harder spectrum in the ATR core region. Therefore, the punching burnup given in Table 13 is considered to be representative of the measured isotopic ratios and is generally the lowest burnup of the fuel plate. Multiplication of this low punching position burnup by the peaking factor (Table 10) for each plate then produced the peak fission density given in Table 13 . The average PDQ calculated fission density is given (Table 13) for comparison. It is found to be approximately the same as the peak fission density. 
Table 12. Mass spectral isotopic ratios for ELAF burnup samples

\begin{tabular}{|c|c|c|c|c|}
\hline \multicolumn{5}{|c|}{ Atom Ratios } \\
\hline Sample & ${ }^{7} 0^{235} \mathrm{U}$ & ${ }^{\% 238} \mathrm{U}$ & ${ }_{0}^{236} \mathrm{U}$ & ${ }^{2}{ }^{234} \mathrm{U}$ \\
\hline 5 & 85.40 & 7.07 & 6.30 & 1.23 \\
\hline 6 & 81.98 & 7.54 & 9.16 & 1.32 \\
\hline 7 & 87.32 & 6.37 & 5.09 & 1.22 \\
\hline 13 & $83.78(83.73)^{\mathrm{a}}$ & 7.19 & 7.79 & 1.25 \\
\hline 19 & 86.92 & 6.58 & 5.29 & 1.20 \\
\hline 20 & $84.95(85.06)^{\mathrm{a}}$ & 7.48 & 6.33 & 1.23 \\
\hline 22 & 87.63 & 6.59 & 4.62 & 1.16 \\
\hline 27 & 86.95 & 6.60 & 5.29 & 1.16 \\
\hline 28 & 83.19 & 7.42 & 8.14 & 1.24 \\
\hline 30 & $85.15(84.64)^{\mathrm{a}}$ & 6.97 & 6.75 & 1.12 \\
\hline 32 & 85.25 & 6.95 & 6.58 & 1.22 \\
\hline 33 & 85.56 & 6.86 & 6.33 & 1.22 \\
\hline
\end{tabular}

a. Analyzed twice.

Table 13. Burnup of ELAF fuel plates from isotopic ratios, peaking factor, and PDQ calculations

\begin{tabular}{|c|c|c|c|c|c|}
\hline $\begin{array}{l}\text { Plate } \\
\text { Number }\end{array}$ & $\begin{array}{c}\text { Uranium } \\
\text { Atom Density } \\
\text { (x 10-21/cc) } \\
\end{array}$ & $\begin{array}{c}\text { Punching Burnup } \\
\text { ( } \% \text { Heavy Element })\end{array}$ & 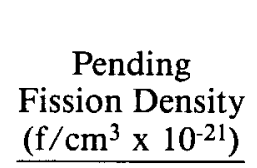 & $\begin{array}{c}\text { Peak } \\
\text { Fission Density } \\
\left(\mathrm{f} / \mathrm{cm}^{3} \times 1^{-21}\right)\end{array}$ & $\begin{array}{c}\text { Average } \\
\text { PDQ Calculation } \\
\text { Fission Density } \\
\left(\mathrm{f} / \mathrm{cm}^{3} \times 1^{-21}\right) \\
\end{array}$ \\
\hline 5 & 5.04 & 22.9 & 1.16 & 1.64 & 1.80 \\
\hline 6 & 5.09 & 30.8 & 1.57 & 2.17 & 2.30 \\
\hline 7 & 5.04 & 19.0 & 0.96 & 1.33 & 1.48 \\
\hline 13 & 6.78 & 27.2 & 1.84 & 3.00 & 2.98 \\
\hline 19 & 6.86 & 19.7 & 1.35 & 1.94 & 2.13 \\
\hline 20 & 6.77 & 23.1 & 1.56 & 2.07 & 2.24 \\
\hline 22 & 6.37 & 17.4 & 1.11 & 1.95 & 1.82 \\
\hline 27 & 6.32 & 19.7 & 1.24 & 2.21 & 1.94 \\
\hline 28 & 6.32 & 28.2 & 1.78 & 2.71 & 2.61 \\
\hline 30 & 5.63 & 24.4 & 1.38 & 2.08 & 2.25 \\
\hline 32 & 5.68 & 23.7 & 1.35 & 1.98 & 2.14 \\
\hline 33 & 5.63 & 23.0 & 1.29 & 1.66 & 2.00 \\
\hline
\end{tabular}




\section{DISCUSSION}

\subsection{Swelling and Fuel Phase Instability}

The ELAF plates were irradiated at a nominal calculated temperature of $395 \mathrm{~K}\left(122^{\circ} \mathrm{C}\right)$ to simulate university fuel plate conditions. This temperature is about $55 \mathrm{~K}$ lower than the nominal temperature for ATR fuel plates 8,9 and intermediate to some other $\mathrm{UAL}_{\mathrm{x}}$ experimental plates 6,10 . The swelling behavior of these plates was similar to other $\mathrm{UAl}_{\mathrm{x}}$ fuel plates when compared at equivalent irradiation temperature and burnup. For example, at a burnup of $2.5 \times 10^{21} \mathrm{f} / \mathrm{cm}^{3}$, the swelling obtained in the ATR plates ${ }^{\mathrm{a}}$ was $6.5 \%$, while the swelling of the ELAF plates ${ }^{\mathrm{a}}$ was $6.2 \%$. The peaking in the swelling of plate 013 (Table 4) of 14.7\% for the high side, and $19.1 \%$ for the high spot, occurs at the higher irradiation temperatures of $150-165^{\circ} \mathrm{C}$ (in Reference 10 ) at about this fission density. From other $\mathrm{UAl}_{\mathrm{x}}$ fuel plates 10 , at $70^{\circ} \mathrm{C}$, the value is about $9 \%$ for thickness and for immersion in carbon tetrachloride. From these ELAF tests (immersion density in water with photoflo as a wetting agent), the swelling value was somewhat lower at $3.8 \%$ for this average burnup of $2.5 \times 10^{21} \mathrm{f} / \mathrm{cm}^{3}$. All of these swelling tests indicate that the $\mathrm{UAI}_{\mathrm{x}}$ fuel-aluminum matrix plates are resistant to the agglomeration of fission gas. The fission product gas is apparently accommodated (for the most part) in solution in the $\mathrm{UAl}_{\mathrm{x}}$ microstructure, most probably in the $\mathrm{UAl}_{4}$ microstructure. The $\mathrm{UAl}_{4}$ body-centered-orthorhombic structure contains a variable number of aluminum atoms (from 4.5 to 4.9 ). $8,20,21$ Thus, the structure contains some empty uranium sites, or sites with smaller aluminum atoms, which may accommodate fission gas products. Therefore, the defect structure of $\mathrm{UAl}_{\mathrm{x}}$ may provide the explanation for the low swelling of these fuels to fairly high burnup $\left(3.0 \times 10^{21} \mathrm{f} / \mathrm{cm}^{3}\right.$ peak for plate 013 in local areas).

As shown in Tables 5 and 7, swelling based on the metallurgical core thickness change includes core changes due to reaction of the $\mathrm{UAl}_{2}$ and aluminum to produce $\mathrm{UAl}_{3}$ and $\mathrm{UAl}_{4}$. Therefore, this method gives swelling values that are too high for irradiation alone. The swelling determined by water immersion density is low because of the low average

a. From thickness measurements. ${ }^{9}$ fission density. The measurement was repeated with the same results. It is noted that since differences are taken in numbers of about the same magnitude, slight inaccuracies cause large changes in the values. It is recommended that the plate-core thickness change $(\Delta t / t)$ from Table 4 or Table 5 be taken as the swelling value for these tests. These are approximately the same as determined for the three failed plates. 12

As noted in these tests and by others, $8,10,20,21,22,23 \mathrm{UAl}_{3}$ is a more stable phase than $\mathrm{UAl}_{2} . \mathrm{UAl}_{2}$ reacts with aluminum to give $\mathrm{UAl}_{3}$ and the nonstoichiometric $\mathrm{U}_{1-\mathrm{x}} \mathrm{Al}_{4}$ phase. The reaction causes a measurable change in the fuel core thickness and volume, but not in the swelling due to irradiation. The swelling as measured by immersion density and plate thickness was determined by the presence of the fission products which mainly stay in solution. As seen in Table 7, approximately one-half the change in core thickness was due to the reaction of $\mathrm{UAl}_{2}$ and $\mathrm{Al}$ to produce $\mathrm{UAl}_{3}$ and $\mathrm{UAl}_{4}$. This change principally occurred during the fabrication process.

The amount of oxygen in the powder blend $(0.37 \%$ oxygen by weight in $\mathrm{JJ}$ blend and $0.11 \%$ oxygen by weight ${ }^{b}$ in the JF blend) is evidently present as $\mathrm{UO}_{2} 16,21$ or $\mathrm{U}_{3} \mathrm{O}_{8}{ }^{24}$. There may be additional oxygen pickup during grinding and compaction of the powder, as occurs in just a halfhour at temperatures less than $350^{\circ} \mathrm{C}$, especially in $\mathrm{UAl}_{2} \cdot{ }^{23,24}$ This U-O phase is evidently the source of the small bubble formation as seen in Figures 10 and 11.16 The topography of the $\mathrm{U}-\mathrm{O}$ phase resembles the appearance of the film of $\mathrm{U}_{3} \mathrm{O}_{8}$ on the surface of $\mathrm{UAl}_{4} / \mathrm{Al}^{24}$

\subsection{Fuel Core Integrity and Bubble Formation}

The fuel core integrity was very good. No cracks or blisters were found and the fission products were principally retained within the fuel structure. A fission fragment stopping zone about 10-20 microns in width was seen at the fuel-clad interface. No bubbles could be seen in this zone, or the fuel surface at $500 \mathrm{X}$ by metallography, or by SEM on the

b. Appendix B. 
polished surfaces at higher magnification. With the SEM on the fracture surfaces, Hoffman ${ }^{16}$ did see small bubbles wherever he saw the U-O phase. The amount of this phase and associated bubbles was not sufficient to affect the integrity of the fuel core as determined by inspection or by blister testing. In over 70 powder particles examined by Kevex-ray on the SEM, this phase was not found in the $J J$ and JF blend powders before fabrication.

The presence and relative amounts of voids after irradiation indicate that the swelling due to the solid fission products has not filled the void spaces as seen in Figure 6 and Table 6. Difficulties in polishing (scratches from the brittle phase) have been attributed to pull out of these brittle intermetallic particles, however the voids are seen after irradiation, ${ }^{3-9}$ as well as before. The low swelling behavior of the $\mathrm{UAl}_{\mathrm{x}}$ fuels has been thought to be partly due to the filling of these voids with the solid fission products. ${ }^{3-9}$ The magnitude of this effect (even at high burnup) is unresolved, although the presence of the voids with the ductile aluminum matrix does not appear detrimental. This seems to be true even at these high burnups where some small bubbles have been detected around the U-O phase.

\subsection{Blister Behavior and Potential Swelling}

The blister temperatures of the plates with $\mathrm{UAl}_{2}$ as the principal constituent were generally as high as those with $\mathrm{UAl}_{3}$ as the principal constituent. For example, the average blister temperature of the three $\mathrm{UAl}_{3}$ plates was $763 \mathrm{~K}$, while that of the nine $\mathrm{UAl}_{2}$ plates was $776 \mathrm{~K}$. However, one plate of the $\mathrm{UAl}_{2}$ composition blistered at $713 \mathrm{~K}$, while two plates of the $\mathrm{UAl}_{2}$ composition did not blister at $833 \mathrm{~K}$ (at burnups of $>2 \times 10^{21} \mathrm{f} / \mathrm{cm}^{3}$ ). Thus, the variability of the blister temperature of the plates of the $\mathrm{UAl}_{2}$ composition was greater than might be expected. This variability might be explained by pockets of gas bubbles associated with the U-O phase, formed during fabrication of the plates. The $\mathrm{U}-\mathrm{O}$ phase was also found ${ }^{16}$ in the plates of $\mathrm{UAl}_{3}$ composition. When the blister temperatures of these ELAF plates were compared with blister temperatures of the ATR composition plates, ${ }^{9}$ all the blister temperatures fell within the three sigma scatter band except the $713 \mathrm{~K}$ temperature of plate 020 .

The potential swelling of plates of the $\mathrm{UAl}_{3}$ or $\mathrm{UAl}_{2}$ composition, as determined from this work, would seem to depend most strongly on these $U$ $O$ phase pockets and associated gas bubbles. The U-O phase probably is formed during the powder grinding and plate rolling fabrication processes and could be diminished by reducing the specification allowed for oxygen (Appendix B).

\subsection{Pitting Corrosion and Plate Life}

Oxide formation and pitting corrosion in aluminum surfaces has received considerable study. 25-32 It is our aim to show that the pitting corrosion of these ELAF plates was not excessive (as compared to other reactor elements, ${ }^{9}$ or other conditions ${ }^{10}$ ) when consideration is made of the temperature and time in the reactor or in the canal (Table 9). As indicated in Section 3.9, when Equation (1) is used to calculate the maximum pitting corrosion of the ELAF plates (Table 9) an estimate results which is reasonable (e.g., as for plate 004) or which overestimates the measured maximum pit depth for most of the plates. But, on one plate (007) the estimate is the same as the measured maximum value. Equation (1) was derived from data from the failed ELAF plates, 12 ATR fuel element corrosion data, 33 and Engineering Test Reactor (ETR) fuel element corrosion data ${ }^{34}$ and allows calculation of the pitting corrosion of the other 14 plates with reasonable values. Therefore, it is evidence that the pitting corrosion in the ELAF plates is not excessive.

Evaluation of pitting corrosion and the application of statistics to the analysis 35,36 indicates, as with the ELAF failed plates, 12 that the measured pit depths can be represented by two straight lines. One line, for pit depths $(\mathrm{X})$ below 2.0 mils, can be represented by the equation

$Y=-0.114+0.43 x$

with a correlation coefficient of $r=0.998$. The other line, for pit depths (X) above 2.0 mils, can be represented by the equation

$Y=0.69+0.034 x$

with correlation coefficient of $r=0.94$. These high correlation coefficients indicate that extreme probability statistics ${ }^{35}$ can represent the data. The value of $\mathrm{Y}$ is the reduced variate; i.e., a function of 
$\frac{M}{n+1}$,

where $M$ is the rank of the pit depth, arranged in increasing order of pit depth (X), from one to the total number and $n$ is the total number. The values of $\mathrm{Y}$ and $\mathrm{X}$ were examined by linear least squares regression analysis, and plotted on extreme probability paper. The return period (i.e., the number of pits at which to expect a pit of a given depth) is different for the small and large pits. For the small pits ( $<2$ mils) one would expect to have over 10,000 pits before getting one with a depth of 7 mils, while for the large pits ( $>2$ mils) the return period is 50 . This representation indicates that the pit incubation time is large or that most of the pits do not propagate at the maximum rate. It has been postulated $30,31,37$ that a critical pitting potential and a protection potential exists for aluminum. Below the critical pitting potential the pit may not initiate or may not grow. The pitting potential decreases with increasing temperature. Other factors also affect the probability that pits will initiate on the fuel plate surface such as: corrosivity of the solution, the solution velocity, the specimen area, and the time of exposure. Because of the occluded cell associated with pitting, the maximum corrosion rate will be less affected by the solution velocity than will pitting initiation. Thus, most of the pits as measured for the ELAF plates are much less than the maximum. During the early stages of pit initiation or growth, the pitting potential is rather unstable. The high concentration of corrosion promoting ions may be swept away by convection currents or the solution velocity. Gravity may have an effect on vertical surfaces, since a difference in solution concentration within a pit is necessary for its continuing activity. Thus, in this irradiation, conditions allow the formation of many pits that do not grow, and a few that do, as protection of the pit is established.
The plate life can thus be affected by the management of the fuel element irradiation sequence and time. Interruption and storage of the fuel elements change the conditions for pit initiation and growth; namely, pitting potential, solution corrosivity, and solution velocity. Interruption and storage of the fuel elements may affect gravity conditions with deposit of solids.

\subsection{Maximum Fission Density}

Although the fission density given for the punching positions in Table 13, (and as stated in Section 3.11) is considered to be representative of the measured isotopic ratios for the ELAF fuel plate punchings, there are two factors which could have affected the maximum values of burnup. The first is the variance on alpha $(\alpha)$, the capture to fission cross section in the I- 9 facility. The variance was estimated to be \pm 0.01 for the spectrum in the I-9 and I-13 facility, in which the plates were irradiated. The effect of this variance (of $\alpha$ on the fission density) was examined. It was found to produce less than a $10 \%$ change in the burnup. The second factor was a constant difference between the PDQ calculated fission density and the fission density obtained from the punchings with $\alpha$ equal to 0.196 . This constant difference amounted to a factor of $1.42 \pm 0.055$ for the 12 plates. It was not possible at this time to assess which was more accurate: the $\mathrm{PDQ}$ calculated fission densities, or the fission densities calculated from the mass spectroscopic isotopic ratios with $\alpha$ equal to 0.196 . Therefore, conservative values of the maximum fission density are considered to be those from the measured isotopic ratios times the peaking factor as presented in Table 13. It is noted that these values are approximately the same as the PDQ calculated average fission densities. 


\section{CONCLUSIONS AND RECOMMENDATIONS}

- An ELAF fuel core with $73 \mathrm{wt} \%$ of the brittle phase $\left(\mathrm{UAl}_{\mathrm{x}}\right)$ gave excellent performance to burnups of $1.84 \times 10^{21} \mathrm{f} / \mathrm{cm}^{3}$ with peaking factors of 1.63 (peak burnup of $3.0 \times 10^{21} \mathrm{f} / \mathrm{cm}^{3}$ ).

- The ELAF fuel plates operated at surface temperatures of about $395 \mathrm{~K}\left(120^{\circ} \mathrm{C}\right)$ with the only evidence of failure due to pitting corrosion.

- Blister temperatures from post irradiation tests of $763 \mathrm{~K}$ for the $\mathrm{UAl}_{3}$ composition, and $776 \mathrm{~K}$ for the $\mathrm{UAl}_{2}$ composition, indicated large margins of safety from overheating for short periods of time.

- The 50 vol\% $\mathrm{UAl}_{2}$ composition plates performed as good or better than the $50 \mathrm{vol} \%$ $\mathrm{UAl}_{3}$ composition plates and will provide higher fuel loading. Although pitting corrosion caused the failure of three plates of the $\mathrm{UAl}_{2}$ composition, a large pit, in the $\mathrm{UAl}_{3}$ composition, in the side of the plate (that would have produced failure) was found.

- Neither the pitting corrosion rate, or the probability of pitting, seemed any greater in the ELAF plates than fuel elements in other reactors when consideration is taken of the plate surface temperature and the time in the water.

- Evidences of small bubbles in pockets were seen in conjunction with uranium oxide, which was probably formed during fabrication of the powder and plates. The blisters that form during post irradiation testing may be associated with these pockets.

- Reaction of the UAl $\mathrm{Ul}_{2}$ to produce $\mathrm{UAl}_{3}$ and the $\mathrm{U}_{1-\mathrm{x}} \mathrm{Al}_{4}$ defect phase causes an increase in core volume of 6 to $12 \%$. The core volume percent thus approaches $60 \mathrm{vol} \%$ of the brittle constituent.

- It is recommended that the specification for oxygen in the powder blends be examined with the view of reducing the allowed oxygen.

- It is recommended that management of the fuel element irradiation sequence be considered as a way to reduce the depth of pitting corrosion and extending fuel element life. 


\section{REFERENCES}

1. L. G. Miller and J. M. Beeston, Fuel Plate and Fusion Insulator Irradiation Test Program, EGG-FT5273, November 1980.

2. L. G. Miller, K. R. Brown, J. M. Beeston, and D. M. McGinty, Extended Life Aluminide Fuel for University Research Reactors, EGG-SE-6464, December 1983.

3. G. W. Gibson, M. J. Graber, and W. C. Francis, Annual Progress Report on Fuel Element Development for FY-1963, IDO-16934, 1963.

4. M. J. Graber et al., Performance Evaluation of Core II and III Advanced Test Reactor Fuel Elements, ANCR-1027, Aerojet Nuclear Company, 1971.

5. M. M. Martin, A. E. Richt, and W. R. Martin, Irradiation Behavior of Aluminum-Base Fuel Dispersions, ORNL-4856, 1973.

6. M. J. Graber et al., Results of ATR Sample Fuel Plate Irradiation Experiment, IDO-16958, 1964.

7. V. A. Walker, M. J. Graber, and G. W. Gibson, ATR Fuel Materials Development Irradiation Results-Part II, IDO-17157, 1966.

8. W. C. Francis, Metallurgy and Materials Science Branch Annual Report Fiscal Year 1970, IN-1437, 1970.

9. J. M. Beeston et al., "Development and Irradiation Performance of Uranium Aluminide Fuels In Test Reactors," Nuclear Technology, 49, June 1980, pp. 136-149.

10. W. Dienst, S. Nazare, and F. Thummler, "Irradiation Behavior of $\mathrm{UAl}_{\mathrm{X}}-\mathrm{Al}$ Dispersion Fuels for Thermal High Flux Reactors," Journal of Nuclear Material, 64, 1, 1977.

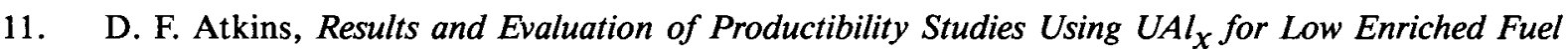
Plates, N275TR000001, Rockwell International, 1979.

12. J. M. Beeston, L. G. Miller, K. R. Brown, and D. M. McGinty, ELAF Failed Fuel Plate Examination, EGG-SE-6696, October 1984.

13. ATR Fuel Element Specification, IN-F-9-ATR, Rev. 5.

14. Extended Life Aluminide Fuel Plates, ES-50607A, November 5, 1980.

15. D. F. Atkins, Development and Fabrication of Extended-Life Aluminide Fuel Plates, N345 TR 000001, Rockwell International, June 1982.

16. Performed by G. Hoffman, Argonne National Laboratory, Chicago.

17. M. L. Griebenow et al., "ATR Startup Fuel-Plate-Cladding Corrosion Test: Preliminary Data and Conclusions," Trans. Am. Nucl. Soc., 14, 761, 1971. Also in TRA Oxide Film Control and Surveillance, RE-77-059, 1972.

18. L. D. Koeppen and J. W. Rogers, Fission Product Distributions in ELAF Fuel Plates, ST-CS-002-86, January 1986.

19. W. J. Maeck, et al., Isotope Correlation Studies Relative to High Enrichment Test Reactor Fuels, ICP1156, June 1978.

20. B. S. Borie, Jr., "Crystal Structure of $\mathrm{UAl}_{4}$," Journal of Metals, 3, September 1951, pp. 800-802.

21. H. J. Eding and E. M. Carr, High Purity Uranium Compounds, ANL-6339, March 1961.

22. M. I. Ivanov, V. A. Tumbakov, and N. S. Podol'skaya, "The Heats of Formation of $\mathrm{UAl}_{2}, \mathrm{UAl}_{3}$, and $\mathrm{UAl}_{4}, "$ Atomnaya Energiya, 5, p. 166 [Sov. S. Atomic Energy, 5, 1958, 1997]. 
23. P. R. Openshaw and L. L. Shreir, "Oxidation of Uranium-Aluminum Intermetallic Compounds," Corrosion Science, 3, 1963, pp. 217-237.

24. P. R. Openshaw and L. L. Shreir, "Oxidation of Uranium-Aluminum Intermetallic Compounds II, Nature and Surface Topography of Oxide Films," Corrosion Science, 4, 1964, pp. 335-344.

25. L. L. Shreir, Corrosion, Volume 1, Metal/Environmental Reactions, Newnes - Butterworths, Boston, 1976, pp. 1:162 and 4:16.

26. N. G. Fontana and N. D. Greene, Corrosion Engineering, McGraw Hill, New York, 1978, pp. 48-58.

27. M. Pourbaix, Atlas of Electrochemical Equilibrium in Aqueous Solutions, Pergamon Press, New York, 1966, pp. 168-176.

28. J. E. Draley, Aqueous Corrosion of 1100 Aluminum and of Aluminum-Nickel Alloys, TID-7587, 1959.

29. D. R. Dickinson, "Oxide Dissolution In Corrosion of Aluminum Cladding on Nuclear Reactor Fuel Elements," Corrosion, 21, January 1965, pp. 19-27.

30. K. Nisancioglu and H. Holtan, "The Protection Potential of Aluminum," Corrosion Science, 18, 1978, pp. 1011-1023.

31. A. Broli and H. Holean, "Determination of Characteristic Pitting Potentials for Aluminum by Use of the Potentiostatic Methods," Corrosion Science, 17, 1977, pp. 59-69.

32. O. Hunderi, "Diffuse Light Scattering: A Way to Study Pitting Corrosion In Situ," Corrosion Science, 19, 9, 1979, pp. 621-630.

33. K. Vinjamuri, Postirradiation Examination of Advanced Test Reactor Fuel Elements $X A 377 N$ and $X A 379 N$, EGG-TFBP-5968, September 1982.

34. J. M. Beeston, ETR Fuel Element Pitting, RE-M-78-012, April 1978.

35. American Society for Testing and Materials, Philadelphia, PA, ASTM G46, Standard Recommended Practice for Examination and Evaluation of Pitting Corrosion.

36. American Society for Testing and Materials, Philadelphia, PA, ASTM G16, Standard Recommended Practice for Applying Statistics to Analysis of Corrosion Data (Reapproved 1977).

37. C. B. Bargeron and R. B. Givens, "Localized Corrosion of Aluminum: Blister Formation as a Precursor of Pitting," Journal of Electrochemical Society, 124, 2, 1977, pp. 1845-48. 
APPENDIX A

\section{IRRADIATION DATA}




\section{APPENDIX A}

\section{IRRADIATION DATA}

Table A-1. Plate irradiation history

\begin{tabular}{|c|c|c|c|c|c|c|c|c|c|}
\hline \multirow[b]{2}{*}{ Position } & \multicolumn{9}{|c|}{ Irradiation Times } \\
\hline & $\begin{array}{c}7-19-81 \text { to } \\
5-6-82\end{array}$ & $\begin{array}{c}10-1-82 \text { to } \\
3-16-83\end{array}$ & $\begin{array}{c}1-27-84 \text { to } \\
3-7-84\end{array}$ & $\begin{array}{l}3-7-84 \text { to } \\
4-24-84\end{array}$ & $\begin{array}{c}4-24-84 \text { to } \\
7-29-84\end{array}$ & $\begin{array}{c}7-29-84 \text { to } \\
9-9-84\end{array}$ & $\begin{array}{l}9-9-84 \text { to } \\
10-21-84\end{array}$ & $\begin{array}{c}10-21-84 \text { to } \\
3-31-85\end{array}$ & $\begin{array}{c}3-31-85 \text { to } \\
6-23-85\end{array}$ \\
\hline \multicolumn{10}{|c|}{ Plate Number } \\
\hline A & 18 & 33 & 30 & 30 & 30 & 30 & 20 & 20 & 20 \\
\hline A & 17 & 32 & 32 & 32 & 36 & 8 & 19 & 19 & 19 \\
\hline $\mathbf{A}$ & 13 & 31 & 31 & 31 & 34 & 34 & 13 & 9 & 6 \\
\hline B & 33 & 16 & 20 & 20 & 20 & 20 & 30 & 30 & 30 \\
\hline B & 32 & 15 & 19 & 19 & 19 & 19 & 8 & 8 & 8 \\
\hline B & 29 & 13 & 13 & 13 & 13 & 13 & 34 & 34 & 34 \\
\hline $\mathrm{C}$ & 4 & 5 & 5 & 5 & 1 & 1 & 1 & 1 & 5 \\
\hline $\mathrm{C}$ & 5 & 6 & 6 & 6 & 6 & 6 & 6 & 6 & 6 \\
\hline $\mathrm{C}$ & 6 & 3 & 7 & 7 & 7 & 7 & 7 & 7 & 7 \\
\hline $\mathrm{D}$ & 23 & 28 & 28 & 28 & 28 & 28 & 28 & 28 & 28 \\
\hline $\mathrm{D}$ & 24 & 27 & 27 & 27 & 27 & 27 & 27 & 10 & 10 \\
\hline $\mathrm{D}$ & 25 & 26 & 26 & 22 & 22 & 22 & 22 & 22 & 22 \\
\hline
\end{tabular}




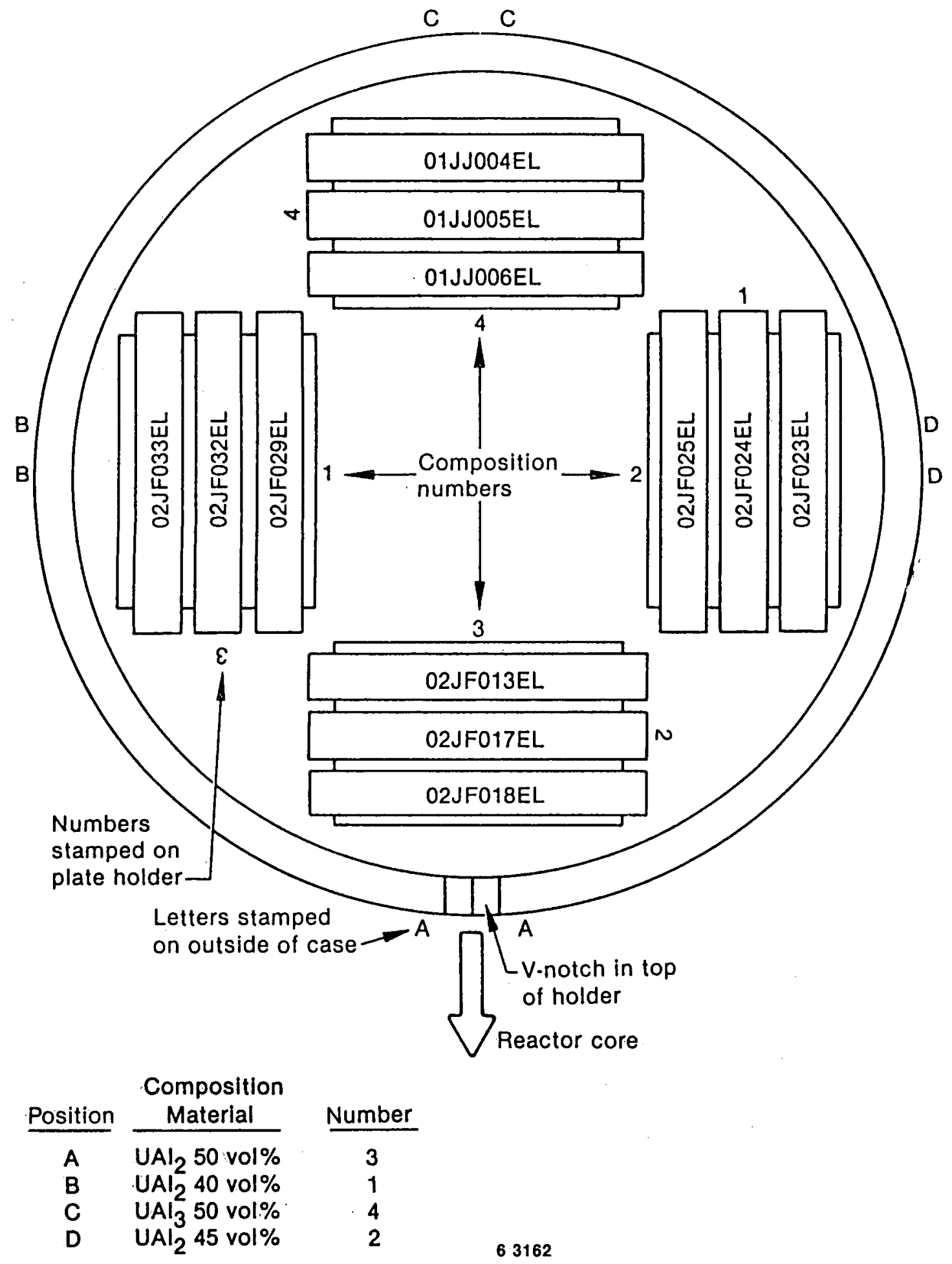

Figure A-1. Fuel plate experimental configuration. 


\section{FISSION PRODUCT RADIONUCLIDE DISTRIBUTIONS IN ELAF FUEL PLATES}

\section{INTRODUCTION}

Twelve ELAF (Extended Life Aluminide Fuel) fuel plates, which were irradiated ${ }^{\mathrm{a}}$ in the ATR (Advanced Test Reactor) I type irradiation positions, were examined by gamma-ray spectroscopy measurements at the TRA (Test Reactor Area) Hot Cell Facility. This work is part of a joint research program to develop fuels for University reactors. The fuel plates were examined at spatial locations along the axis and edges of the fuel containing regions. The purpose of these measurements was to determine the distribution of gamma-ray emitting fission product radionuclides in the fuel. These results will be combined with radiochemical analyses of samples taken from the fuel plates to determine the overall fuel burn-up in each plate.

\section{SCANNING EQUIPMENT AND ANALYSIS METHODS}

Scanning is accomplished using the TRA Hot Cell scanner which consists of: (1) the scanner bed with a horizontal and vertical drive system, (2) a collimator which penetrates the hot cell well, (3) a $\mathrm{Ge}$ (Li) gamma-ray detector with associated electronics, (4) a two peak precision pulser for automatic spectral gain calibration, and (5) a Fabri-Tek MP-12 microcomputer for local control of the scanner bed and gamma spectral data acquisition. The system is controlled remotely via a Vadic Full Duplex Modem data link between the Fabri-Tek computer and the P.DP-11/44 computer, located in the Radiation Measurements Laboratory (RML). The operator can load a sequence of commands on the PDP-11 which will execute a predetermined scan sequence. During remote operations, the scanner bed can be positioned at a predetermined point; a 4096 channel gamma-ray spectrum accumulated for a predetermined period of time, and the spectral data transferred to the PDP-11/44 where it is automatically stored and analyzed. The scanner bed will then be automatically positioned at the next predetermined scan point and the entire process repeated. The operation is terminated when the last scan point entered in the command sequence has been analyzed.

a. See Table A-1 and Figure A-1.
The scanner bed has two Slo-Syn stepping motors which are directly coupled to the $\mathrm{X}$ (Horizontal) and $Y$ (Vertical) drive lead screws with end-of-travel limit switches for each drive. The scanner bed travel is limited to $60 \mathrm{in}$. of horizontal movement and $7 \mathrm{in}$. of vertical movement, with a spatial resolution of $0.01 \mathrm{in}$. The stepping pulses for each motor and the limit switch signals to the MP-12 motor drive interface are optically coupled to reduce the effects of noise from the motors and translators. The $\mathrm{X}$ drive can be operated at two speeds. The fast speed is $16 \mathrm{in.} / \mathrm{min}$ and is utilized during initial "set-up" when determining the location of the radioactive objects and the variations of their radioactivity. The slow speed is $2 \mathrm{in} . / \mathrm{min}$ and is used mostly for the gross activity profile scanning. The $\mathrm{Y}$ drive operates at a fixed speed of $2 \mathrm{in} . / \mathrm{min}$.

Six different sized collimators are presently available for use. The collimators are a section of round stainless steel stock about $4 \mathrm{ft}$ long and $3 \mathrm{in}$. in diameter, each with a different size collimation opening (slit) which penetrates through the entire length. Five collimators have openings which are all $0.500 \mathrm{in}$. in height and have widths of $0.010 \mathrm{in.,} 0.020 \mathrm{in} ., 0.040 \mathrm{in}$, $0.080 \mathrm{in}$. and 0.250 . A collimator with a larger opening is also available; it has a collimation opening of $1.00 \mathrm{in}$. height and $0.50 \mathrm{in}$. width. The collimator penetrates the hot cell wall and presents a collimated gamma-ray beam to the detector which is situated outside the hot cell. The selection of collimator size is dependent on the gamma intensity of the item being scanned. The size selected is usually determined by the counting rate the detector is experiencing. Occasionally there exist situations where the item being scanned has such a relatively low count rate that the collimator needs to be completely removed and the gamma scanning done through the resultant 3 in. diameter opening. The collimator can be rotated to position the slit for either axial (horizontal) or transverse (vertical) scans. The $0.040 \mathrm{in}$. width collimator was used during scanning of the ELAF fuel plates.

The reference locations of the top and bottom of a fuel region, and its centerline, are determined by a gross scan stepping technique. With the collimator oriented horizontally, the rod is moved in small steps in the vertical direction. A $10 \mathrm{~s}$ count is done at each location (step) and a visual inspection is made of the resultant spectrum. A total integrated gross count is also tabulated at that time. The two locations at which sharp changes in 
total gross gamma count rate occur and "key" isotopes are observed are noted. The axial centerline of the fuel is calculated from the measurement of the fuel axial boundaries. The locations of the fuel top and bottom are determined by orienting the collimator vertically, positioning its midpoint at the axial centerline of the fuel, and noting the point at which the gross gamma count rate changes sharply and "key" isotopes are observed while stepping from a position clearly off the fuel to a position clearly on the fuel. "Key" isotopes are defined at the radionuclides, which are determined to be unique to the fuel being scanned.

After all the initial gross activity data is examined and the isotopic scan locations are determined, the RML PDP-11/44 is programmed for the automatic scan sequence of the fuel plate. The RML PDP-11/44 analysis procedure performs the following functions on each gamma-ray spectrum:

- Energy calibrates the spectrum based on the pulser data.

- Searches the spectrum for all prominent peaks.

- Energies of selected peaks from the summary file will be written to the limit library. This ensures answers will be obtained for all desired peaks.

- Fit all found and selected peaks to a Gaussian distribution.

- Performs decay corrections if necessary.

- Subtracts background values for each peak if they exist in the background spectrum.

- Prints the results from all peaks on a line printer.

- Writes results of the specified energy peaks to a summary file.

\section{DESCRIPTION OF MEASUREMENTS}

The spectroscopy data consists of 4096 channel spectra of gamma counts versus energy at preselected locations on each fuel plate. The spatial locations for gamma-ray spectroscopy measurements on each fuel plate were selected in order to: (1) provide both axial (fuel length) and transverse (fuel width) distributions, (2) obtain spectroscopy measurements at exactly the same spatial locations where the samples for radiochemical analyses will be removed, and (3) provide sufficient high quality data in a cost effective and timely way.

Sketches of radiographs from each plate showed the location and dimensions of the fuel region, and the distance from the end of the fuel to the end of the plate. Each fuel plate was gamma-scanned from the bottom to the top. From these scans, the ends of the fuel regions were accurately determined and the zero reference positions were established relative to the bottom end of each plate. The fuel dimensions determined by the gamma-scans step technique agreed (on the average) with the dimensions from the radiographs to within $0.04 \mathrm{in}$. on the lengths and within $0.02 \mathrm{in}$. on the widths. This good agreement demonstrates that very accurate positioning is established relative to the bottom end of the plates.

The collimator used in the measurements has actual opening dimensions of 0.040 in. $x 0.500$ in. Because of the distance from the collimator to the fuel plates, the actual area of the fuel plate which is viewed by the collimator-detector arrangement is 0.055 in. $x 0.688$ in.

In order to obtain sufficient counting statistics, count times for the gamma-ray spectroscopy measurements (to determine the fission products radionuclide distributions in these plates) varied from $500 \mathrm{~s}$ to $900 \mathrm{~s}$ depending on the counting rates.

\section{RESULTS}

The results from these measurements are given in relative counts per second for each individual radionuclide. Since no efficiency calibrations exist for these measurements, quantitative activities and gammaintensities are undetermined. Therefore, the counts per second of one radionuclide are not related to another radionuclide. All the data have been decay corrected to 6-23-85@2000 hr, and corrected for any background activities in the hot cell.

The results are presented on sketches of the fuel plates which illustrate the location where each measurement was taken, the orientation of the collimator, and the area viewed by the collimator detector. Each scan-point location is shown with an asterisk. The 
associated count rate (counts/second) and uncertainty is shown to the right of each asterisk.

Random uncertainties, including the counting statistics and photopeak fitting components, are reported.
At the centerline locations (1.75 in., 4.54 in., 6.40 in. and $9.40 \mathrm{in}$.) the uncertainty also includes the scanner system reproducibility component. These positions were each measured twice in order to better establish the uncertainties, including positioning. 


\section{APPENDIX B}

\section{CORE AND PLATE DATA}


APPENDIX B

CORE AND PLATE DATA

Table B-1. Core and plate specifications

\begin{tabular}{|c|c|c|c|c|c|c|c|c|c|c|c|}
\hline \multirow[b]{2}{*}{$\begin{array}{c}\begin{array}{c}\text { Plate } \\
\text { Number }\end{array} \\
\end{array}$} & \multirow[b]{2}{*}{$\begin{array}{c}\text { Core } \\
\text { Compact } \\
\text { wt } \\
(\mathrm{g}) \\
\end{array}$} & \multirow[b]{2}{*}{$\begin{array}{c}\mathrm{UAl}_{\mathbf{X}} \\
\mathrm{wt} \\
(\mathrm{g}) \\
\end{array}$} & \multicolumn{9}{|c|}{ Plate Preirradiation } \\
\hline & & & $\begin{array}{l}\text { Dry } \\
\text { wt } \\
\text { (g) } \\
\end{array}$ & $\begin{array}{l}\text { Wet } \\
\text { wt } \\
(\mathrm{g}) \\
\end{array}$ & $\begin{array}{c}\text { B-10 } \\
w t \\
(\mathrm{~g}) \\
\end{array}$ & $\begin{array}{c}\mathrm{U} \\
\mathrm{wt} \\
(\mathrm{g}) \\
\end{array}$ & $\begin{array}{l}\text { Actual } \\
\text { Core } \\
\text { Volume } \\
\left(\mathrm{cm}^{3}\right) \\
\end{array}$ & $\begin{array}{c}\mathrm{U} \\
\text { Density } \\
\left(\mathrm{g} / \mathrm{cm}^{3}\right)\end{array}$ & $\begin{array}{c}\text { Void } \\
\text { Volume } \\
(\%) \\
\end{array}$ & $\begin{array}{c}\text { Plate } \\
\text { Thickness } \\
\text { (in.) } \\
\end{array}$ & $\begin{array}{c}\text { Core } \\
\text { Length } \\
\text { (in.) } \\
\end{array}$ \\
\hline & 50 vol\% & $\mathrm{UAl}_{3}$ & & & & & & & & & \\
\hline 01 & 11.94 & 8.076 & 32.25 & 21.92 & 0.014 & 5.73 & 2.882 & 2.0 & 7.23 & 0.0510 & 10.31 \\
\hline 03 & 11.96 & 8.075 & 32.17 & 21.86 & 0.014 & 5.73 & 2.899 & - & 7.51 & 0.0510 & 10.44 \\
\hline 04 & 11.95 & 8.076 & 32.29 & 21.95 & 0.014 & 5.73 & 2.881 & - & 7.07 & 0.0512 & 10.37 \\
\hline 05 & 11.94 & 8.076 & 31.99 & 21.73 & 0.014 & 5.73 & 2.908 & 1.970 & 8.04 & 0.0510 & 10.50 \\
\hline 06 & 11.95 & 8.076 & 32.23 & 21.91 & 0.014 & 5.73 & 2.883 & 1.988 & 7.13 & 0.0512 & 10.56 \\
\hline 07 & 11.95 & 8.075 & 32.18 & 21.85 & 0.014 & 5.73 & 2.912 & 1.968 & 8.04 & 0.0511 & 10.44 \\
\hline 08 & 11.94 & 8.075 & 32.10 & 21.82 & 0.014 & 5.73 & 2.888 & - & 7.39 & 0.0511 & 10.50 \\
\hline 09 & 11.96 & 8.075 & 32.31 & 21.95 & 0.014 & 5.73 & 2.898 & - & 7.47 & 0.0514 & 10.56 \\
\hline 10 & 11.95 & 8.075 & 32.16 & 21.85 & 0.014 & 5.73 & 2.899 & - & 7.50 & 0.0512 & 10.69 \\
\hline
\end{tabular}

Average 7.49

$50 \mathrm{vol}^{\%} \mathrm{UAl}_{2}$

$\begin{array}{rrrrrrrrrrrr}13 & 13.70 & 10.057 & 33.41 & 23.18 & 0.020 & 7.93 & 2.998 & 2.645 & 10.98 & 0.0510 & 10.62 \\ 15 & 13.70 & 10.057 & 33.53 & 23.23 & 0.020 & 7.93 & 3.024 & 2.622 & 11.75 & 0.0512 & 10.56 \\ 16 & 13.69 & 10.057 & 33.41 & 23.16 & 0.020 & 7.93 & 3.014 & 2.631 & 11.49 & 0.0510 & 10.62 \\ 17 & 13.69 & 10.057 & 33.47 & 23.19 & 0.020 & 7.92 & 3.023 & - & 11.72 & 0.0511 & 10.62 \\ 18 & 13.70 & 10.057 & 33.56 & 23.30 & 0.020 & 7.92 & 2.973 & - & 10.23 & 0.0513 & 10.62 \\ 19 & 13.68 & 10.058 & 34.02 & 23.60 & 0.020 & 7.93 & 2.956 & 2.683 & 9.87 & 0.0519 & 10.69 \\ 20 & 13.69 & 10.057 & 33.96 & 23.52 & 0.020 & 7.92 & \mathbf{3 . 0 0 2} & \mathbf{2 . 6 3 8} & \mathbf{1 1 . 0 2} & \mathbf{0 . 0 5 2 0} & \mathbf{1 0 . 7 5}\end{array}$

Average 11.01

$\underline{45 \mathrm{vol}_{0} \mathrm{UAl}_{2}}$

$\begin{array}{llllllllllll}22 & 13.01 & 9.039 & 33.04 & 22.83 & 0.018 & 7.12 & 2.860 & 2.49 & 7.23 & 0.0510 & 10.37 \\ 23 & 13.02 & 9.038 & 32.95 & 22.77 & 0.018 & - & 2.867 & - & 7.32 & 0.0509 & 10.56 \\ 24 & 13.02 & 9.038 & 33.12 & 22.90 & 0.018 & - & 2.845 & - & 6.59 & 0.0513 & 10.56 \\ 25 & 13.02 & 9.038 & 32.96 & 22.74 & 0.018 & - & 2.904 & - & 8.48 & 0.0511 & 10.50 \\ 26 & 13.01 & 9.037 & 33.08 & 22.84 & 0.018 & - & 2.875 & - & 7.73 & 0.0512 & 10.56 \\ 27 & 13.03 & 9.037 & 32.84 & 22.68 & 0.018 & 7.13 & 2.891 & 2.466 & 8.08 & 0.0509 & 10.62 \\ 28 & 13.00 & 9.039 & 33.12 & 22.86 & 0.018 & 7.12 & 2.877 & 2.475 & 7.62 & 0.0510 & 10.62\end{array}$

Average 7.58 


\begin{tabular}{|c|c|c|c|c|c|c|c|c|c|c|c|}
\hline \multirow[b]{2}{*}{$\begin{array}{c}\text { Plate } \\
\text { Number } \\
\end{array}$} & \multirow[b]{2}{*}{$\begin{array}{c}\text { Core } \\
\text { Compact } \\
\text { wt } \\
(\mathrm{g}) \\
\end{array}$} & \multirow[b]{2}{*}{$\begin{array}{c}\mathrm{UAl}_{\mathrm{X}} \\
\mathrm{wt} \\
(\mathrm{g}) \\
\end{array}$} & \multicolumn{4}{|c|}{$\cdot$} & \multicolumn{5}{|c|}{ Plate Preirradiation } \\
\hline & & & $\begin{array}{l}\text { Dry } \\
\text { wt } \\
(\mathrm{g})\end{array}$ & $\begin{array}{l}\text { Wet } \\
\text { wt } \\
(\mathrm{g})\end{array}$ & $\begin{array}{l}\text { B-10 } \\
\text { wt } \\
(\mathrm{g})\end{array}$ & $\begin{array}{l}\mathrm{U} \\
\mathrm{wt} \\
(\mathrm{g})\end{array}$ & $\begin{array}{l}\text { Actual } \\
\text { Core } \\
\text { Volume } \\
\left(\mathrm{cm}^{3}\right) \\
\end{array}$ & $\begin{array}{c}\mathrm{U} \\
\text { Density } \\
\left(\mathrm{g} / \mathrm{cm}^{3}\right)\end{array}$ & $\begin{array}{c}\text { Void } \\
\text { Volume } \\
(\%)\end{array}$ & $\begin{array}{c}\text { Plate } \\
\text { Thickness } \\
\text { (in.) }\end{array}$ & $\begin{array}{c}\text { Core } \\
\text { Lengt] } \\
\text { (in.) }\end{array}$ \\
\hline & 40 vol $\%$ & $\mathrm{UAl}_{2}$ & & & & & & & & & \\
\hline $\begin{array}{l}29 \\
30 \\
31 \\
32 \\
33 \\
34 \\
36\end{array}$ & $\begin{array}{l}12.51 \\
12.51 \\
12.51 \\
12.51 \\
12.50 \\
12.51 \\
12.51\end{array}$ & $\begin{array}{l}8.018 \\
8.018 \\
8.019 \\
8.019 \\
8.018 \\
8.018 \\
8.018\end{array}$ & $\begin{array}{l}32.82 \\
32.93 \\
32.81 \\
32.99 \\
32.49 \\
32.98 \\
33.09\end{array}$ & $\begin{array}{l}22.50 \\
22.56 \\
22.46 \\
22.63 \\
22.28 \\
22.60 \\
22.66\end{array}$ & $\begin{array}{l}0.016 \\
0.016 \\
0.016 \\
0.016 \\
0.016 \\
0.016 \\
0.016\end{array}$ & $\begin{array}{l}6.33 \\
6.32 \\
6.32 \\
6.32 \\
6.32 \\
6.32 \\
6.33\end{array}$ & $\begin{array}{l}2.867 \\
2.877 \\
2.901 \\
2.845 \\
2.875 \\
2.868 \\
2.878\end{array}$ & $\begin{array}{c}2.208 \\
2.197 \\
- \\
2.221 \\
2.198 \\
- \\
-\end{array}$ & $\begin{array}{l}5.81 \\
6.02 \\
6.80 \\
4.96 \\
6.08 \\
5.75 \\
5.94 \\
\end{array}$ & $\begin{array}{l}0.0513 \\
0.0519 \\
0.0515 \\
0.0515 \\
0.0510 \\
0.0519 \\
0.0520\end{array}$ & $\begin{array}{l}10.62 \\
10.62 \\
10.62 \\
10.69 \\
10.62 \\
10.62 \\
10.62\end{array}$ \\
\hline & & & & & & & & Averag & 5.91 & & \\
\hline
\end{tabular}




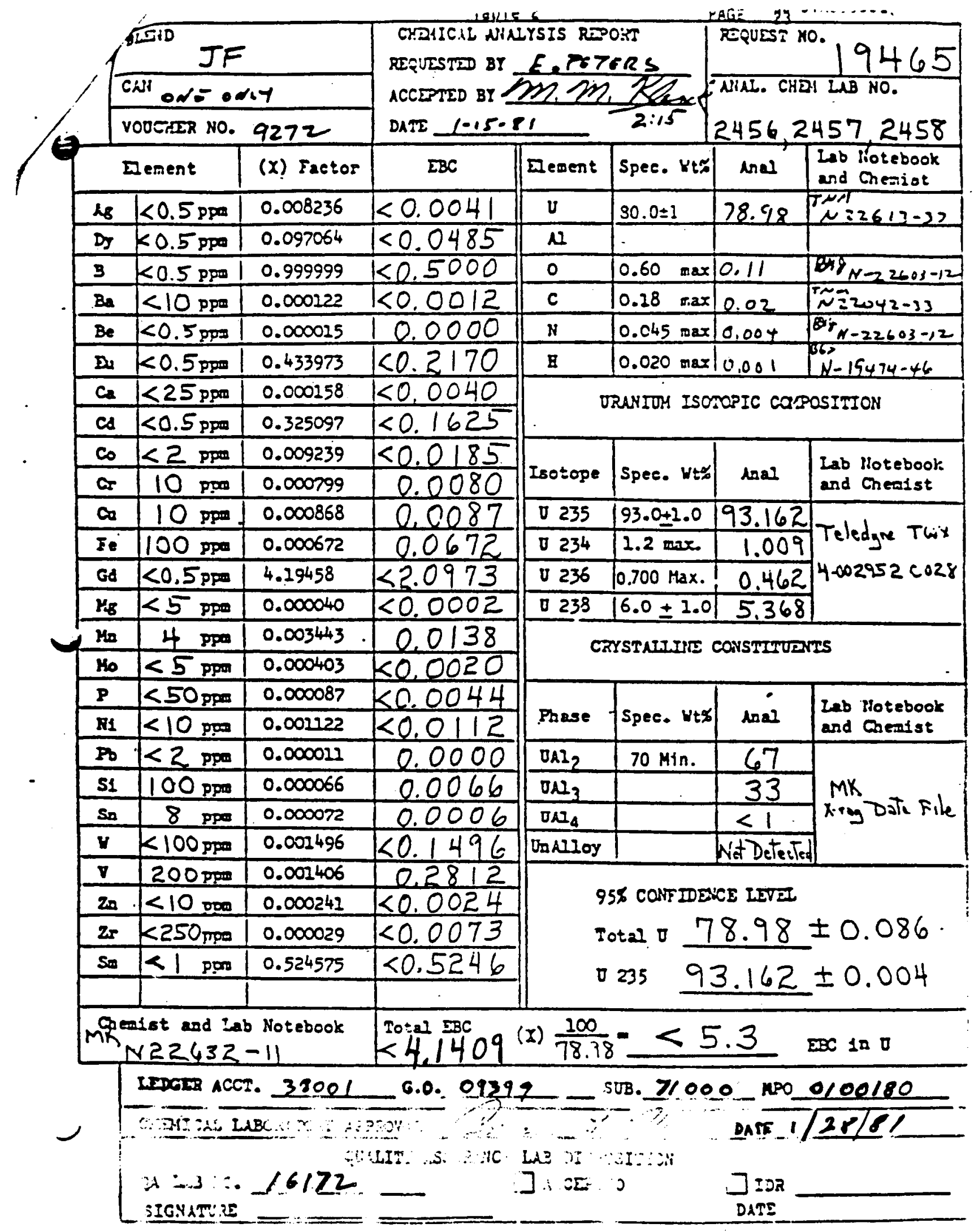



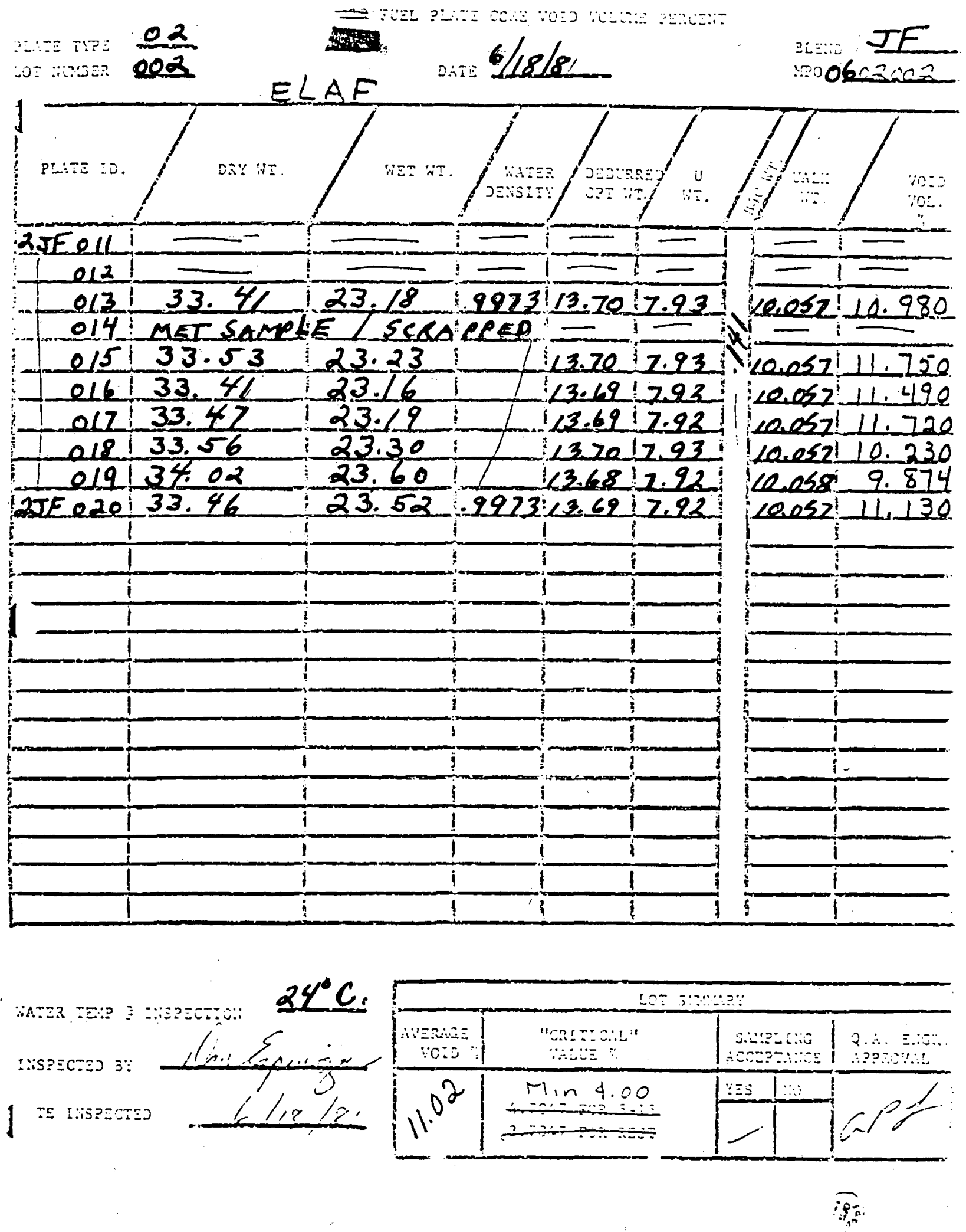
:Li: T:Ee $\frac{02}{003}$

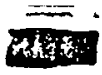

Dite $6 / 18 / 81$

s:: IE

:?0 0602003

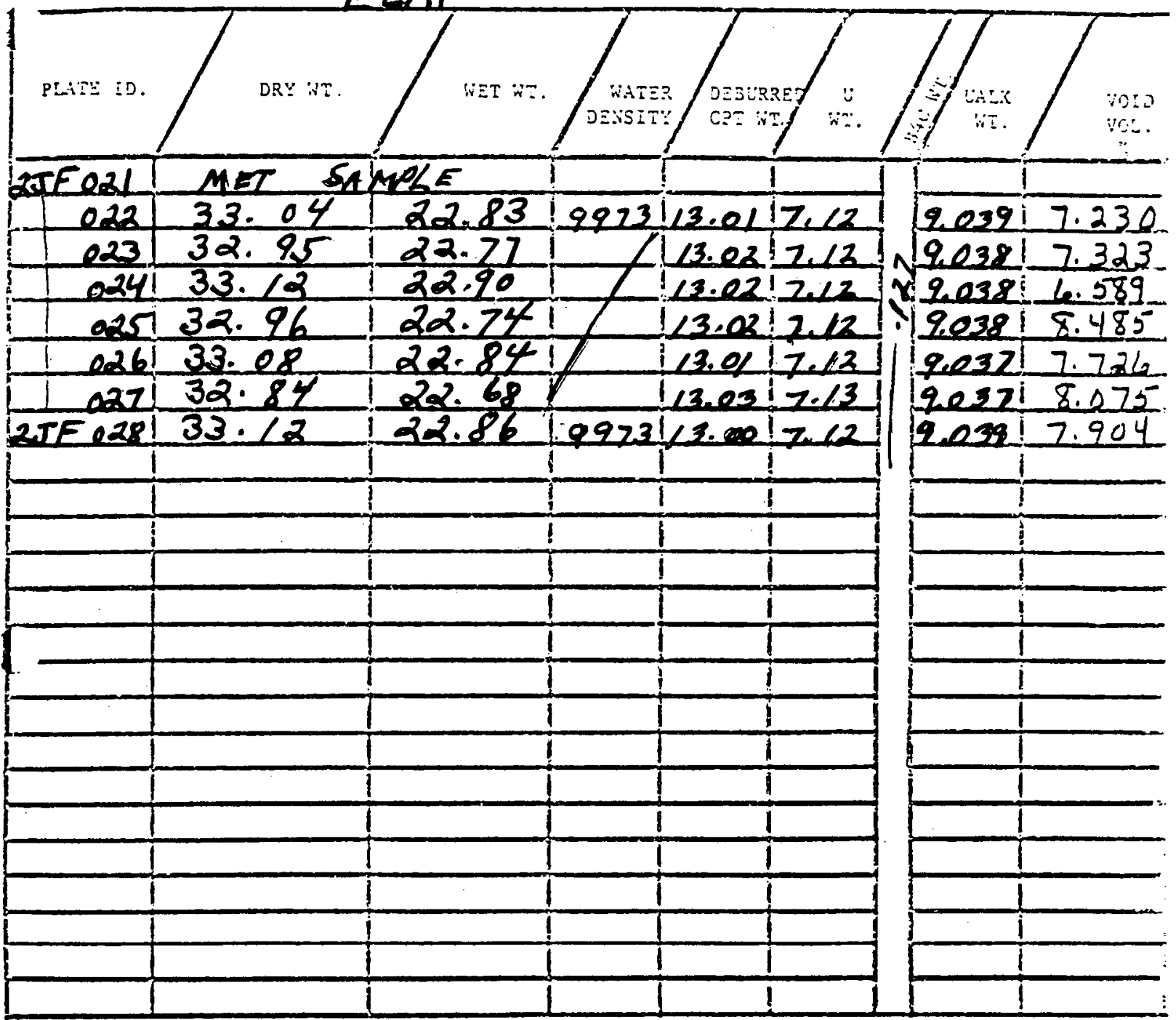

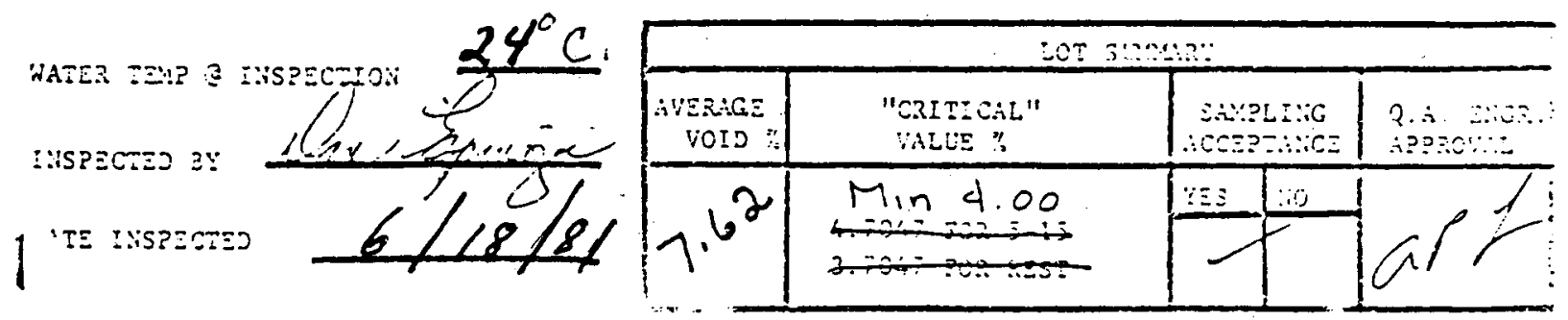




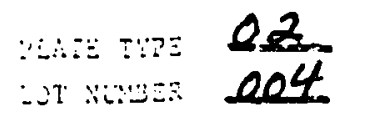

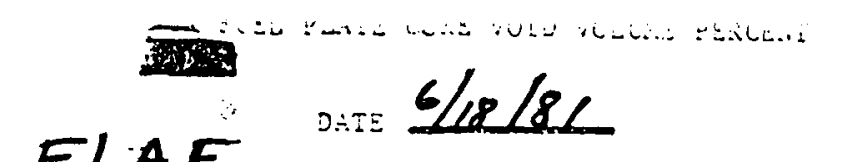

$\frac{T F}{100602004}$

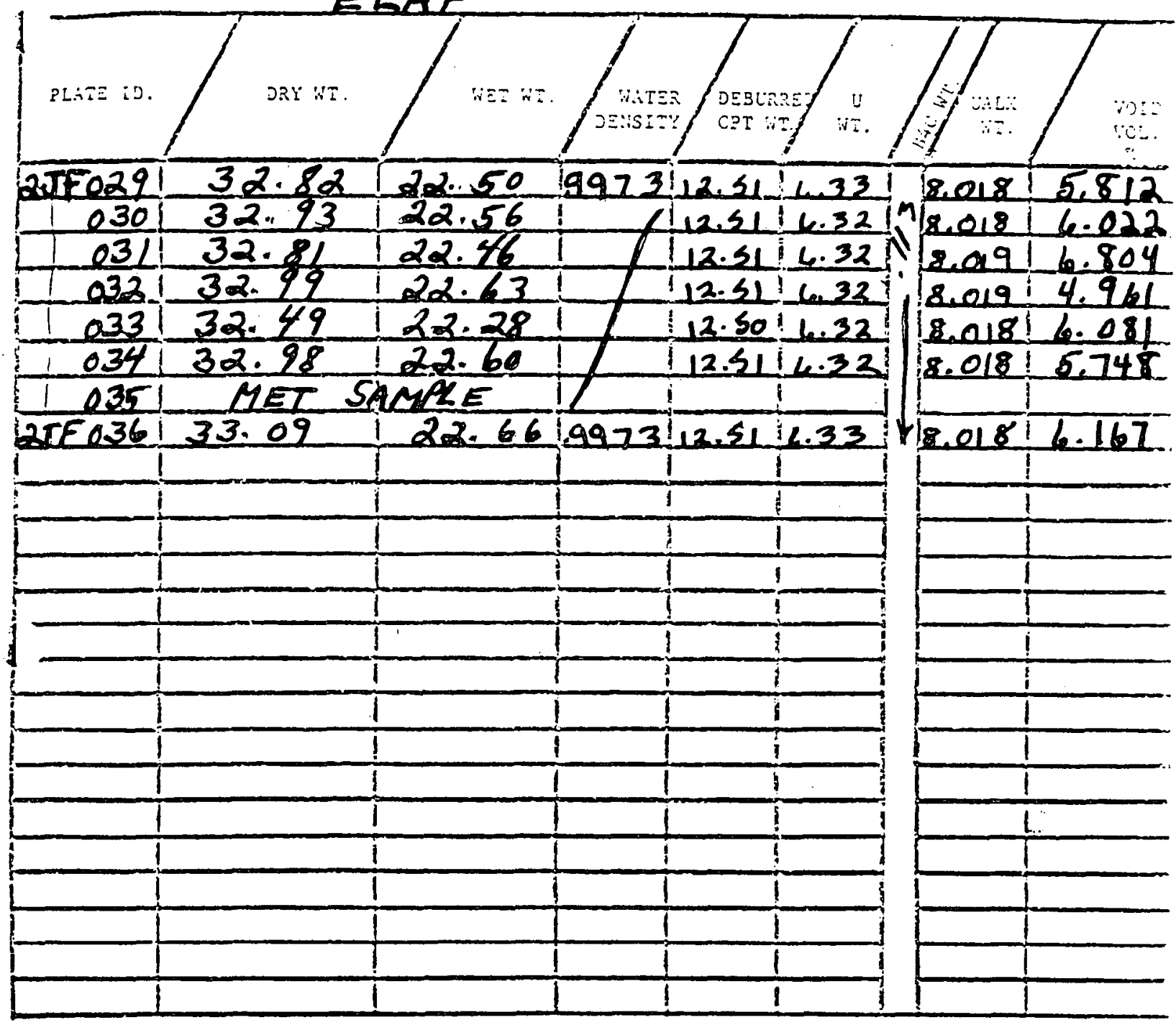

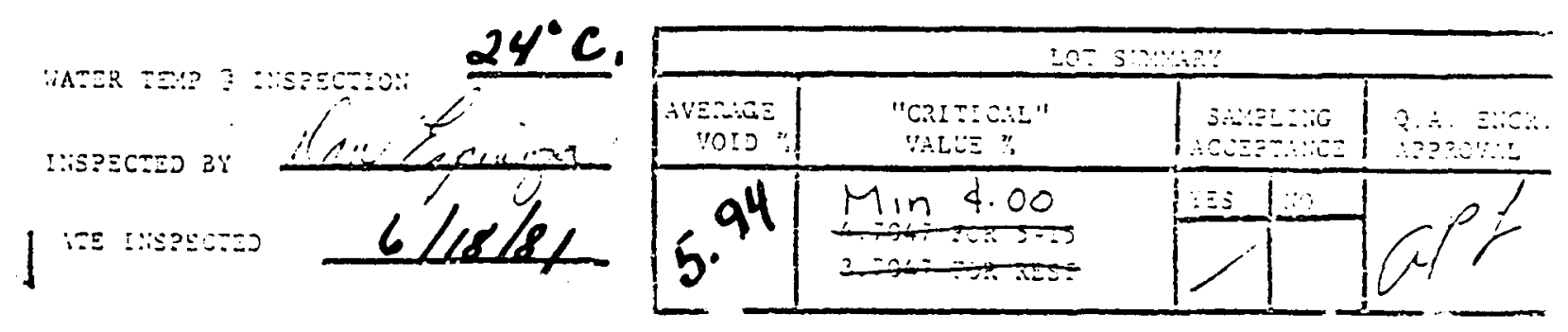

济 
HPUR M A. in 102532

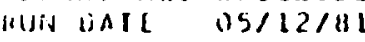

ALLOIMENT NC. JHAJZIYJ3r

I AUKICATILN CATE OS/CE/B

progkar Ac. CLit

\begin{tabular}{|c|c|c|}
\hline PLAIE-NC. & $\begin{array}{l}\ln (X) \\
W T\end{array}$ & $\begin{array}{c}B(4) \mathrm{C} \\
\mathrm{h} 1\end{array}$ \\
\hline$\therefore \mathrm{Jt} J \mathrm{~J} 1 \mathrm{ll}$ & 12.057 & .141 \\
\hline$\therefore 11) 012 \mathrm{LL}$ & 10.058 & .141 \\
\hline$\therefore) \ln 3 \mathrm{~L} \mathrm{~L}$. & 10.057 & .141 \\
\hline$\therefore$ Jf $1214 L L$ & 10.258 & .141 \\
\hline$\therefore A 1 \cap \cap \mathrm{glL}$ & $|c .05|$ & .141 \\
\hline LJIOULGLL & 10.057 & .141 \\
\hline$\therefore$ J JOI IEL L & 13.257 & .141 \\
\hline$\because 31001 \mathrm{BLL}$ & 10.057 & .141 \\
\hline$\therefore J 100191 . \mathrm{L}$ & 10.058 & .141 \\
\hline$\angle J I O O \angle C E,$. & 10.057 & .141 \\
\hline
\end{tabular}

IIITALS $=130.573 \quad 1.410$
DILHICS INTERATTICNAL

ALCLEAK FLDIE HAEHICAIICA HECCAC

NNA TACRICAIICA AC. AIJT-C4

NFC FAERICAIICA AC. DZCC2-tL

BLEAL ZL $=7 E .9 E$ ZL2 $25=5.3 .162$ BCFCA LCT IZEL: 241014.21

\begin{tabular}{|c|c|c|c|c|c|c|c|c|c|}
\hline $\begin{array}{l}A L \\
\text { hT }\end{array}$ & $\begin{array}{l}\text { SLM CF } \\
\qquad A P L I-b I\end{array}$ & $\underset{h I}{\text { ZCEURREC }}$ & $\begin{array}{l}\text { INV } \\
h 1\end{array}$ & $\underset{n I}{U}$ & $\begin{array}{c}4(235) \\
\text { h } 1\end{array}$ & $\begin{array}{c}B(10) \\
\text { ni }\end{array}$ & $\begin{array}{l}* \quad \text { CEEL } \\
N L I-n I\end{array}$ & $\mathrm{C}$ & $\begin{array}{l}\operatorname{ArC}(A) \\
\quad(12 Z E)\end{array}$ \\
\hline $\begin{array}{l}3.526 \\
3.526 \\
3.526 \\
3.526 \\
3.526 \\
3.525 \\
3.524 \\
3.526 \\
3.526 \\
3.525\end{array}$ & $\begin{array}{l}13.72 \\
13.73 \\
13.72 \\
13.73 \\
11.12 \\
13.72 \\
11.72 \\
13.72 \\
13.72 \\
13.72\end{array}$ & $\begin{array}{l}13.67 \\
13.70 \\
13.70 \\
13.10 \\
13.70 \\
13.65 \\
13.65 \\
13.70 \\
13.68 \\
13.65\end{array}$ & $\begin{array}{l}1 C .02 \\
10.04 \\
10.04 \\
1 C . C 4 \\
1 C .04 \\
1 C . C 3 \\
1 C .03 \\
1 C .04 \\
1 C .03 \\
10.03\end{array}$ & $\begin{array}{l}7.51 \\
1.53 \\
7.53 \\
7.53 \\
7.93 \\
7.52 \\
7.52 \\
1.93 \\
7.92 \\
7.92\end{array}$ & $\begin{array}{l}7.37 \\
1.39 \\
7.35 \\
7.35 \\
7.24 \\
7.34 \\
1.38 \\
1.34 \\
7.38 \\
7.38\end{array}$ & $\begin{array}{l}.02 C \\
.02 C \\
.02 C \\
.02 C \\
.02 C \\
.02 C \\
.02 C \\
.02 C \\
.02 C \\
.02 C\end{array}$ & $\begin{array}{l}.05 \\
.03 \\
.02 \\
.03 \\
.02 \\
.03 \\
.03 \\
.02 \\
.04 \\
.03\end{array}$ & $\begin{array}{l}.03 \\
.01 \\
.01 \\
.01 \\
.01 \\
.02 \\
.02 \\
.01 \\
.012 \\
.02\end{array}$ & $\begin{array}{l}. C 2 \\
. C C \\
.62 \\
. C C \\
. C C \\
. C 1 \\
. C 1 \\
. C C \\
. C 1 \\
. C 1\end{array}$ \\
\hline 15.254 & 137.22 & 136.52 & $1 C C .34$ & 75.24 & $\begin{array}{l}73.84 \\
\text { SCHAF } \\
\text { CIFFEK }\end{array}$ & $\begin{array}{l}.200 \\
A E I= \\
\text { RACE }\end{array}$ & $\begin{array}{l}.30 \\
.15 \\
.15-\end{array}$ & $.1 t$ &.$c t$ \\
\hline
\end{tabular}




$$
\text { 11 } 1911-111111
$$

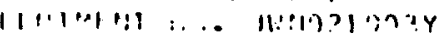

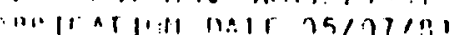

$: 1 \cdots, 2+1949.911$

\begin{tabular}{|c|c|c|}
\hline ים & $\begin{array}{l}13.11|\times| \\
1.1\end{array}$ & $\begin{array}{l}n 1111,1 \\
1: 1\end{array}$ \\
\hline $11 \cdot 1.1 .11$ & $\therefore$. & .11 ! \\
\hline$\|$ רin & "^l" & $.11 ?$ \\
\hline 1127111 & " & .11: \\
\hline ו"ונים & $\therefore .71 .1$ & $.11 ?$ \\
\hline 1110211 & r.n & $.11 ?$ \\
\hline $1127: 4$ & $4.71 \%$ & $.11 ?$ \\
\hline $11 !) !+4$ & r. 71. & .112 \\
\hline 111111 & חות & $.11:$ \\
\hline $11111:=$ & c.s. $1: 7$ & . \\
\hline
\end{tabular}

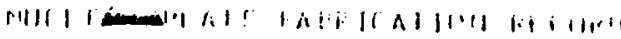

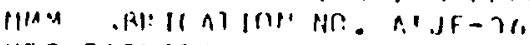

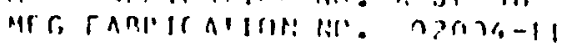

Prim $81:=74.99 \quad 21 \% 35=91,19.2$

linent! in 1251 ?

\begin{tabular}{|c|c|c|c|c|c|c|c|c|c|}
\hline 11 & Sim ar & DГLUJPFD & INV & 11 & $(11225)$ & $n(1))$ & \multicolumn{2}{|c|}{ * DI:BUFRFO } & AMDUIIT \\
\hline י1 & IMIUT-NT & $W$ & WT & WI & WI & 111 & 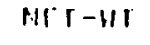 & 11 & U(2) 35 \\
\hline $\begin{array}{l}4.394 \\
4.491\end{array}$ & $12.5 ?$ & !. 2.51 & A.n! & 6.33 & 5,89 &.$\eta 1 \%$ &.$n 7$ &.$n n$ & \\
\hline $\begin{array}{l}4.4 .71 \\
4.4+71\end{array}$ & 12.51 & $1 ? .51$ & 0.11 & $0, ? ?$ & 5.49 & . nI & $.7 \%$ & .01 & \\
\hline $\begin{array}{l}4.4+71 \\
4.97 .7\end{array}$ & 17.51 & 12.51 & ภ. 7) & 6.32 & 5. 99 &.$n 16$ & .92 & .01 &.$n$ \\
\hline $\begin{array}{l}4.9 n=1 \\
4.4 n n\end{array}$ & 12.53 & !?.11 & $9.2 n$ & 1..1? & 5.31 & $.9 ! 6$ & .72 & .01 & $.0 r$ \\
\hline $\begin{array}{l}4.4 n n \\
4.471\end{array}$ & $\begin{array}{l}17.53 \\
12.53\end{array}$ & $12.5 n$ & $1 . n n$ & 6.37 & $3 . R_{i}$ & $-\cap 16$ & .113 & .71 & .7 \\
\hline 4.391 & $\begin{array}{l}17.53 \\
12.53\end{array}$ & $1 ? .51$ & ก.77 & 6.32 & ร. 139 & $\cdot n \mid A_{1}$ & .92 & .01 & - $n$ \\
\hline i. inn & $\begin{array}{l}1.2 .35 \\
17.53\end{array}$ & $\begin{array}{l}12.57 \\
17.51\end{array}$ & $\begin{array}{l}n .77 \\
9.01\end{array}$ & $\begin{array}{l}0.32 \\
6.33\end{array}$ & $\begin{array}{l}5.9(1) \\
5 . B(1)\end{array}$ & .916 & $=13$ & $=n 1$ & . n \\
\hline 5.199 & $139 . .3$ & 100.06 & 64.72 & 59.58 & 41.12 & .128 & 13 & $n$ & \\
\hline & & & & & $\begin{array}{l}\text { SRRAr } \\
\text { DIF! rR }\end{array}$ & $\begin{array}{l}\text { PIF: }= \\
\text { FHSE }\end{array}$ & $\begin{array}{l}.15 \\
.79-\end{array}$ & & \\
\hline
\end{tabular}


[PUERT A.C. HiC.102532

lis llalk Dis/12/81

I HITNAS NC. JWAO2LHO3Y

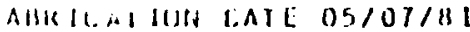

iel, , 1 AN R1). 1.101

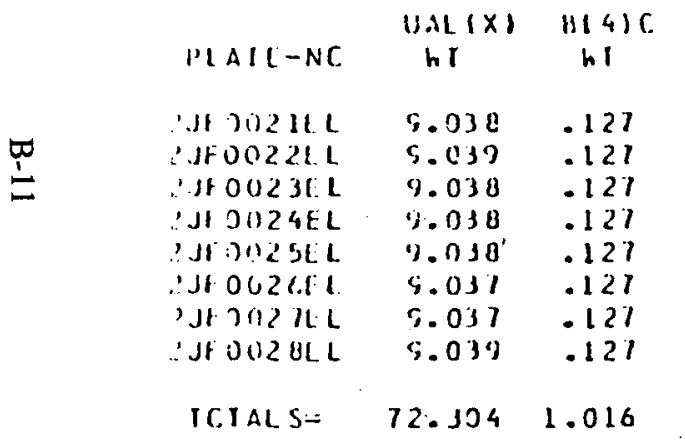

\begin{abstract}
AICNICS INICKAATICAAL
NUCLEAK FLAIE TAEPICAIICA RLCCHL

NHN IAERICAIICA AC. AIJI-OE

MLE FAERICAIICA AC. GZCCB-EL

ELEAC $\quad$ IU $=7 E-4 E \quad 21235=53.162$

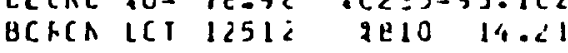

\begin{tabular}{|c|c|c|c|c|c|c|c|c|c|}
\hline $\begin{array}{l}A L \\
\text { WT }\end{array}$ & $\begin{array}{l}\text { SLM CF } \\
\text { IAFLI-hI }\end{array}$ & $\begin{array}{c}\text { LEQLRREC } \\
\text { WT }\end{array}$ & $\begin{array}{l}\text { InV } \\
\text { hI }\end{array}$ & $\begin{array}{l}U \\
h T\end{array}$ & $\begin{array}{c}(1235) \\
h 1\end{array}$ & $\begin{array}{c}E(10) \\
h T\end{array}$ & AEI-hI & L & $\begin{array}{l}A P C L A 1 \\
\quad(1<3 \leq 1)\end{array}$ \\
\hline $\begin{array}{l}3.883 \\
3.881 \\
3.883 \\
3.482 \\
3.882 \\
3.881 \\
3.882 \\
3.882\end{array}$ & $\begin{array}{l}13.05 \\
13.05 \\
13.05 \\
13.05 \\
13.05 \\
13.05 \\
13.05 \\
13.05\end{array}$ & $\begin{array}{l}13.02 \\
13.01 \\
13.02 \\
13.02 \\
13.02 \\
13.01 \\
13.03 \\
13.00\end{array}$ & $\begin{array}{l}S . C 2 \\
5 . C 1 \\
5.02 \\
9.02 \\
5.02 \\
5 . C 1 \\
5.03 \\
\text { S.C1 }\end{array}$ & $\begin{array}{l}1.12 \\
1.12 \\
1.12 \\
1.12 \\
7.12 \\
1.12 \\
1.13 \\
1.12\end{array}$ & $\begin{array}{l}t .64 \\
t .63 \\
t .64 \\
6 . t 5 \\
t .64 \\
t .63 \\
6.04 \\
t .63\end{array}$ & $\begin{array}{l}.018 \\
.011 \\
.011 \\
.01 E \\
.01 E \\
. C 1 E \\
.018 \\
.01 E\end{array}$ & $\begin{array}{l}.03 \\
.04 \\
.03 \\
.03 \\
.03 \\
.04 \\
.02 \\
.05\end{array}$ & $\begin{array}{l}.02 \\
.02 \\
.02 \\
.62 \\
.02 \\
.62 \\
.01 \\
.02\end{array}$ & $\begin{array}{l}. C 1 \\
. C 1 \\
. C 1 \\
. C 1 \\
. C 1 \\
. C 1 \\
. C 1 \\
. C C \\
.01\end{array}$ \\
\hline .31 .056 & $1 C 4.4 C$ & 104.13 & $72: 14$ & 56.97 & $\begin{array}{l}53 . C D \\
\text { SCKAF } \\
\text { UIFFE }\end{array}$ & $\begin{array}{l}.144 \\
A \in I= \\
\text { AEACE }\end{array}$ & $\begin{array}{l}.27 \\
.2 t \\
-C 1-\end{array}$ & .15 &.$(2)$ \\
\hline
\end{tabular}




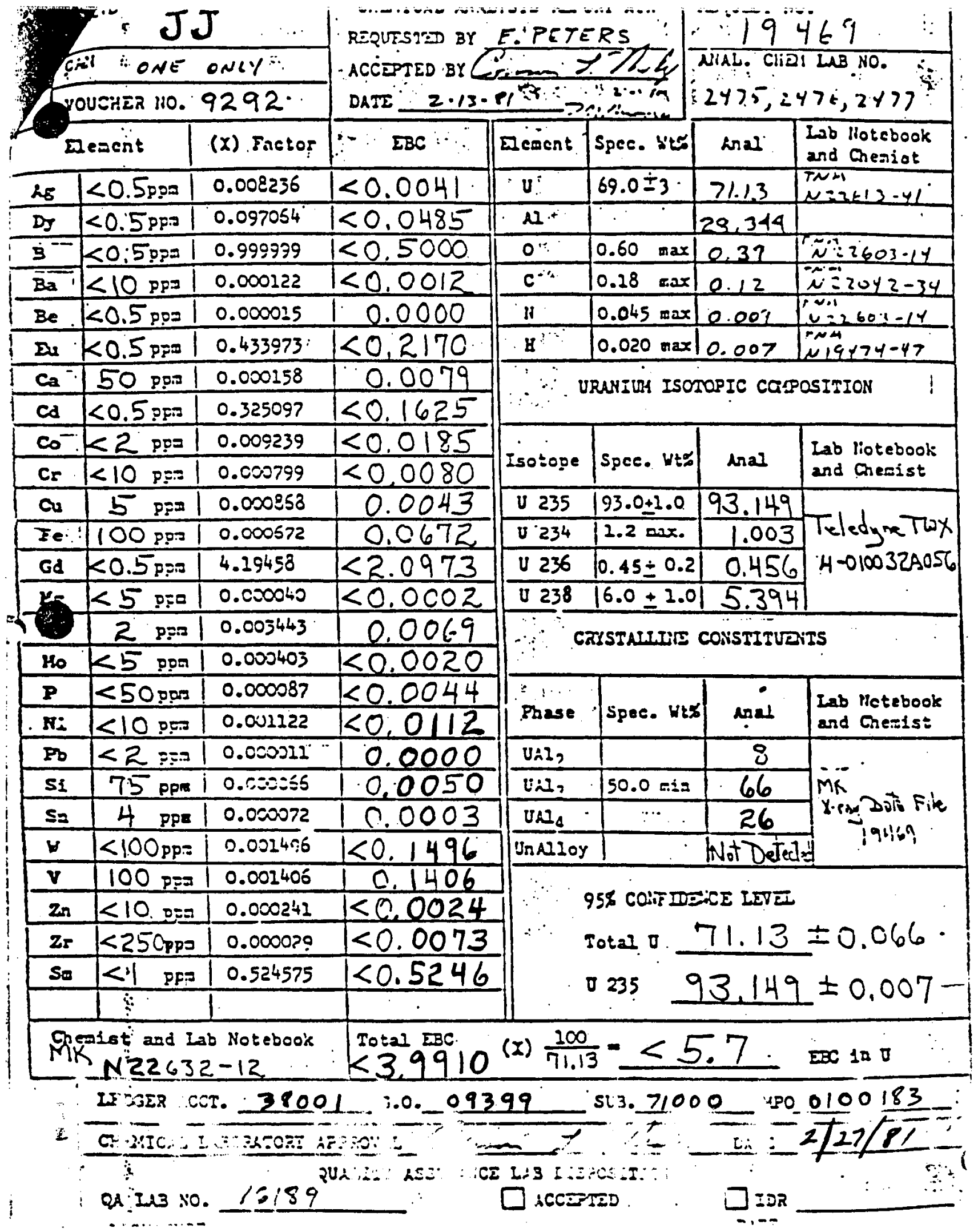




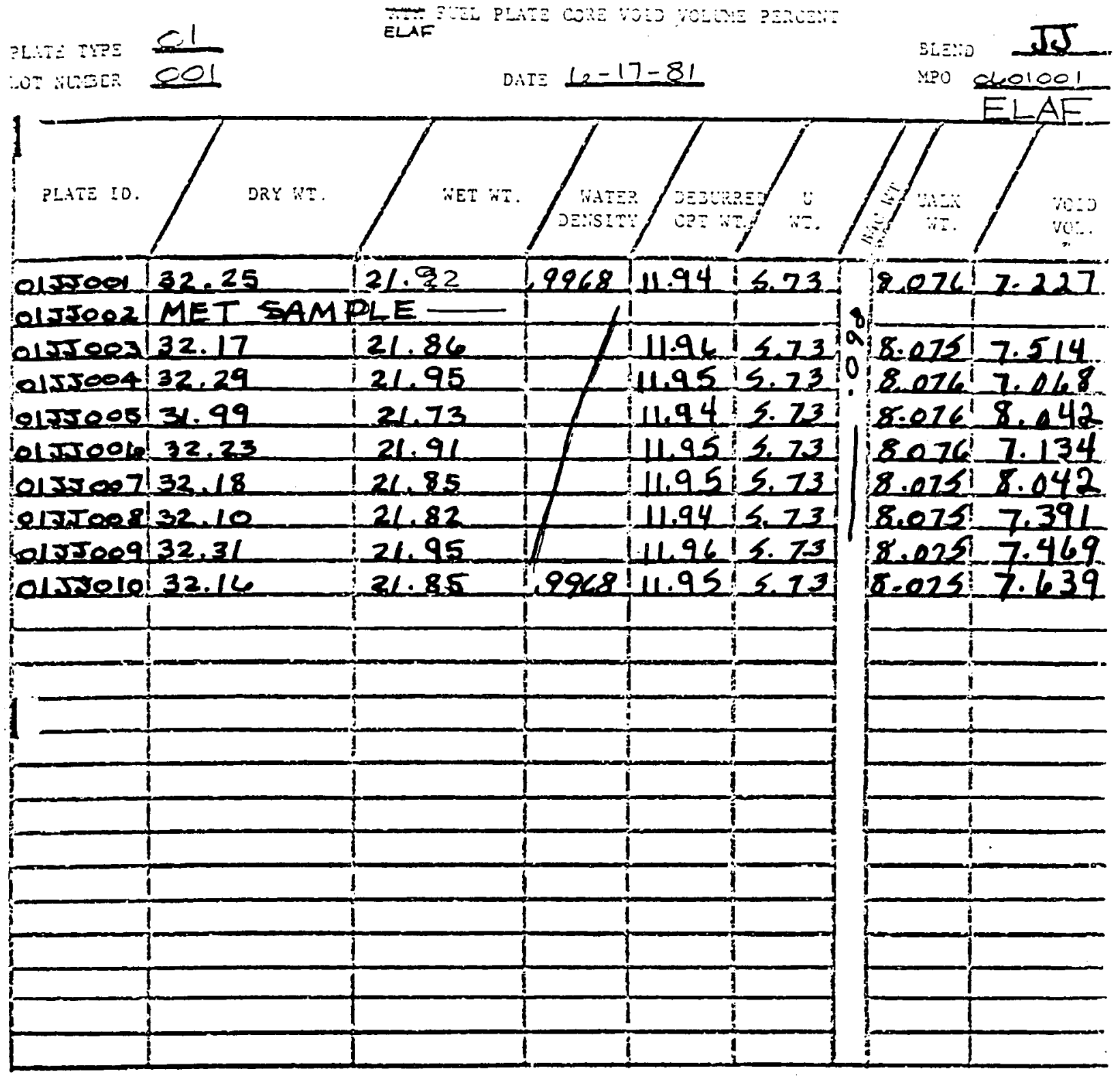

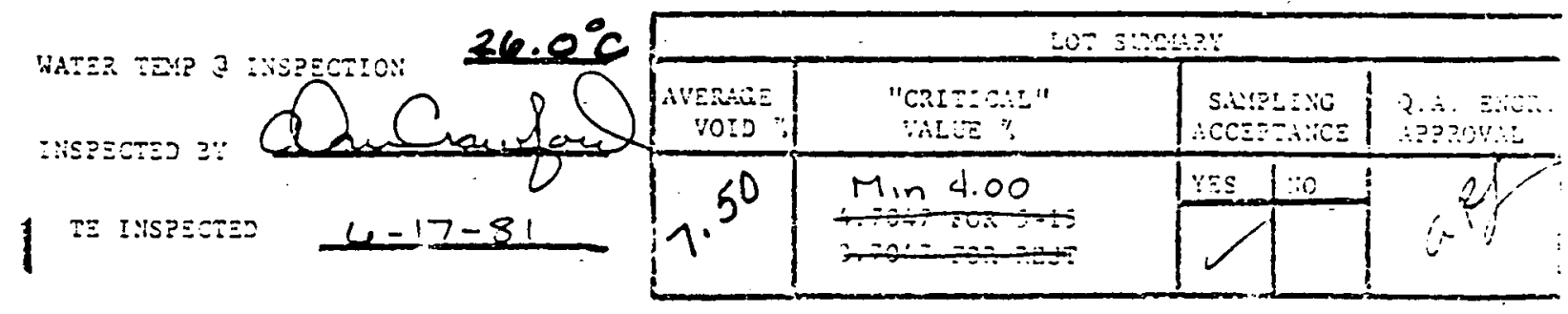


ORT HC. nit 102532

- bijl: 0s/12/81

WNERI NC. JWAJZLISJY

IIICAIICN LATE 05/06/8I

i,HAH NC. LLOI

\begin{tabular}{|c|c|c|}
\hline$A+E-110$ & $\underset{h T}{\operatorname{Ln}(X)}$ & $\begin{array}{c}B(4) C \\
h T\end{array}$ \\
\hline 1000111 & 11.076 & .048 \\
\hline 10021.1 & B. $\cos 5$ & .090 \\
\hline 100OSLL & 0.075 & .098 \\
\hline L & 0.016 & .090 \\
\hline OONOSEL & 0.076 & $.0 \% 0$ \\
\hline .)010<EL & 0.076 & $=0, \theta$ \\
\hline IJUOIE:L & $0.0 / 5$ & .090 \\
\hline $10 C O B E L$ & 8.075 & .048 \\
\hline ¡JOOYEL & 0.075 & $-0 \operatorname{los}$ \\
\hline $10010 E L$ & 0.075 & .090 \\
\hline $141.5=$ & 40.754 & .580 \\
\hline
\end{tabular}

\begin{tabular}{|c|c|c|c|c|c|c|c|c|}
\hline \multicolumn{6}{|c|}{ 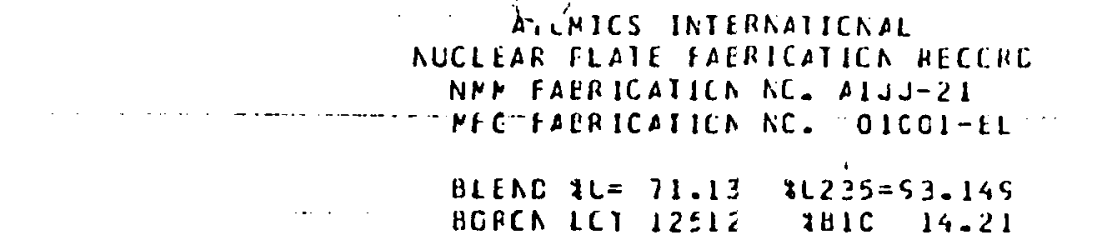 } & & & CE \\
\hline $\begin{array}{l}A L \\
H T\end{array}$ & $\begin{array}{c}S L M \text { OF } \\
-\mid \Lambda P(-T-b \mid\end{array}$ & $\begin{array}{l}\text { DERURREC I IAV } \\
\cdots\end{array}$ & $\cdots U$ & $\ldots \operatorname{hi}^{U(235)}$ & $\begin{array}{c}1110) \\
n 1\end{array}$ & - ACIEELRRCL & $\begin{array}{l}0 \\
u\end{array}$ & 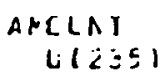 \\
\hline $\begin{array}{l}3.806 \\
3.807 \\
3.807 \\
3.006 \\
3.801 \\
3.806 \\
3.805 \\
3.866 \\
3.807 \\
3.806\end{array}$ & $\begin{array}{l}11.98 \\
11.5 E \\
11.9 E \\
11.9 E \\
11.5 E^{--} \\
11.9 E \\
11.9 E \\
11.9 E \\
11.9 E \\
11.9 E\end{array}$ & $\begin{array}{l}11.54 \\
11.54 \\
11.56 \\
11.95 \\
11.94 \\
11.95 \\
11.55 \\
11.54 \\
11.56 \\
11.55\end{array}$ & 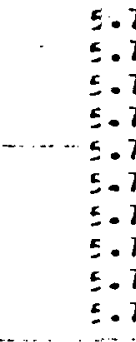 & $\begin{array}{ll}3 & 5.33 \\
3 & 5.33 \\
3 & 5.34 \\
3 & 5.34 \\
3 & 5.33 \\
3 & 5.34 \\
3 & 5-34 \\
3 & 5.31 \\
3 & 5.34 \\
3 & E .34\end{array}$ & 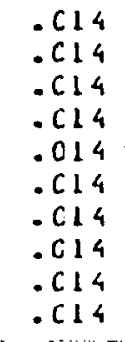 & $\begin{array}{l}.04 \\
.04 \\
.02 \\
.03 \\
.04 \\
.03 \\
.63 \\
.04 \\
.02 \\
.03\end{array}$ & $\begin{array}{l}.01 \\
. C 1 \\
-C 1 \\
-C 1 \\
. C 1 \\
-C 1 \\
-C 1 \\
-C 1 \\
. C 1 \\
. C 1 \\
-C 1 \\
. C 1\end{array}$ & $\begin{array}{l}. C C \\
-C C \\
-C C \\
-C C \\
-C C \\
. C C \\
. C C \\
. C C \\
-C C \\
. C C\end{array}$ \\
\hline 38.062 & $119.8 \mathrm{C}$ & 115.48 & 57.3 & $\begin{array}{l}\text { SCHAF } \\
\text { CIFFER }\end{array}$ & $\begin{array}{l}.140 \\
\text { AEI } \\
\text { LACE }\end{array}$ & $\begin{array}{l}.32 \\
.64 \\
.2 E-\end{array}$ & .10 &.$C C$ \\
\hline
\end{tabular}




\section{ELAF FUEL PI_ATE}

Gamma Scan

(.040 in. $x .500$ in. collimator)

ACTUAL AREA VIEWED $=.055 \mathrm{in} . \times .688 \mathrm{in}$.

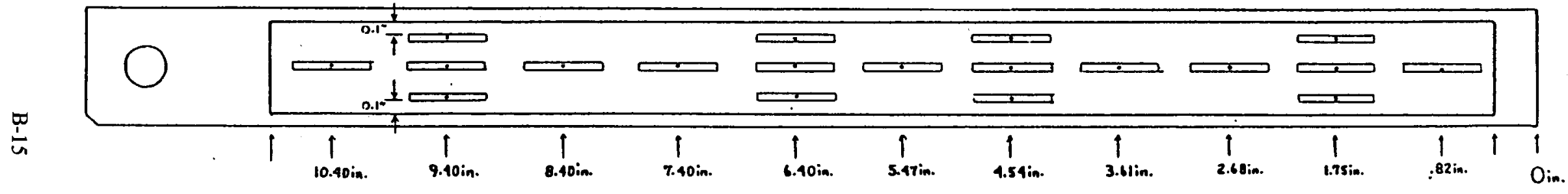


No. 5

RADIONUCLIDE: ${ }^{95} \mathrm{Zr}$

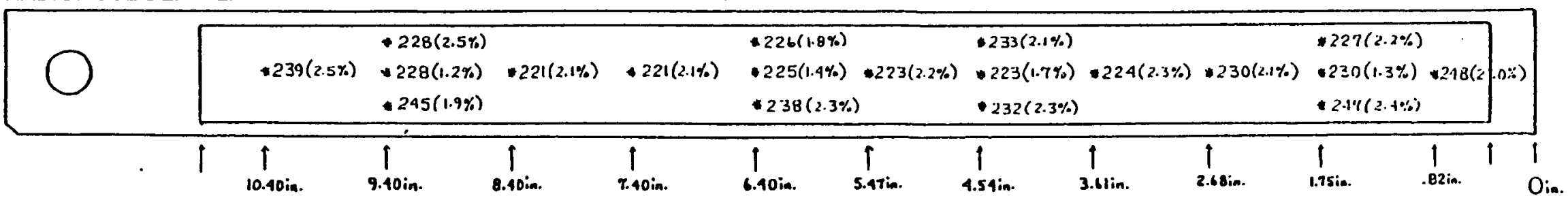

No. 5

RADIONUCLIDE: ${ }^{103} \mathrm{RU}$

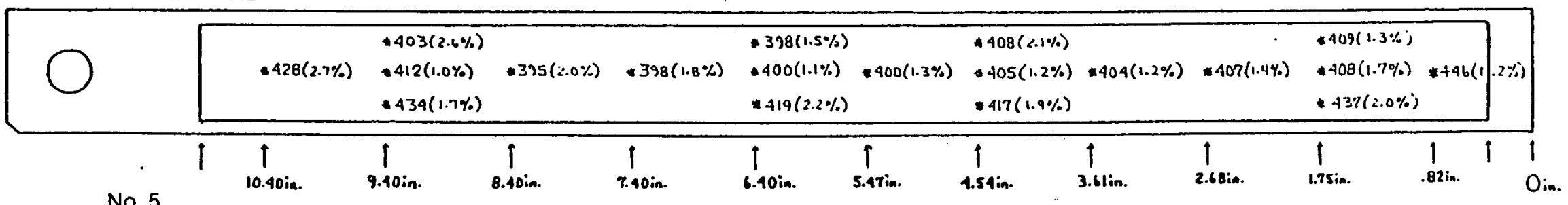

No. 5

RADIONUCLIDE: ${ }^{134} \mathrm{Cs}$

\begin{tabular}{|c|c|c|c|c|c|c|c|c|c|}
\hline & \multirow{3}{*}{$-3.29(2.0 \%)$} & \multicolumn{2}{|l|}{$0.15(2.690)$} & \multirow{3}{*}{$.8 .68(4.3 \%)$} & \multirow{3}{*}{$\begin{array}{l}=9.34(3.1 \%) \\
=0.58(1.6 \%) \cdot 8.67(2.0 \%) \\
=10.4(2.3 \%)\end{array}$} & \multicolumn{2}{|l|}{$+9.26(2.0 \%)$} & $8.99(2.8 \%)$ & \multirow{3}{*}{$2 \%)$} \\
\hline & & $-8.61(2.8 \%)$ & $\Delta 8.41\left(2.1 Y_{0}\right)$ & & & $8.36(2.2 \%)$ & $=8.58(2.7 \%) \cdot 8.76(3.6 \%)$ & $.8 .55(2.0 \% \%) \cdot 7.95(z$ & \\
\hline & & $-10.4(2.5 \%)$ & & & & $=10.1(1.9 \%)$ & & $.11 .0(2.4 \%)$ & \\
\hline I & $\overbrace{10.40 \mathrm{in} .}$ & $\prod_{9.10 \mathrm{in} .}$ & $\int_{8.40 \mathrm{in} .}^{1}$ & $1_{\text {T.40in. }}^{1}$ & $\prod_{\text {s.4Tim. }}$ & 1 & $\overbrace{2.60 \mathrm{in} .}$ & $\int_{1.75 \mathrm{i} .}^{1}$ & \\
\hline
\end{tabular}

No. 5

RADIONUCLIDE: ${ }^{137} \mathrm{Cs}$

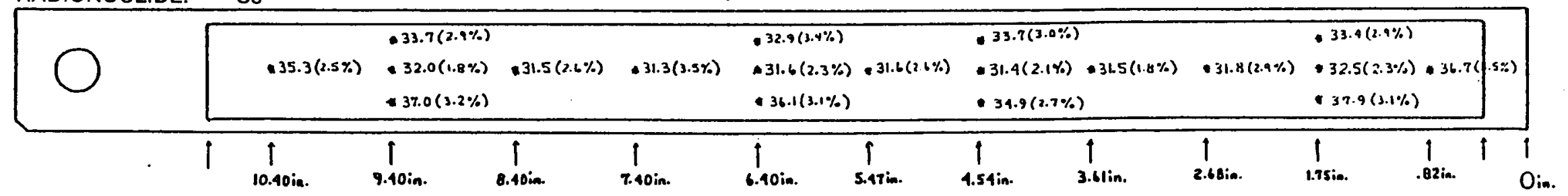


No. 5

RADIONUCLIDE: ${ }^{144} \mathrm{C}$

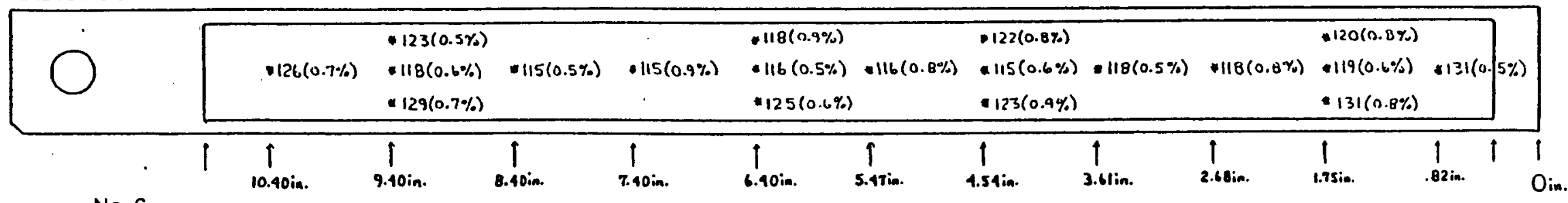

No. 6

RADIONUCLIDE: $95 \mathrm{Zr}$

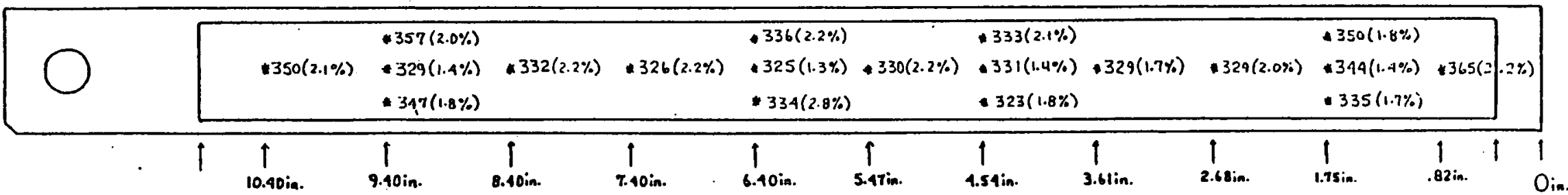

No. 6

RADIONUCLIDE: ${ }^{103} \mathrm{Ru}$

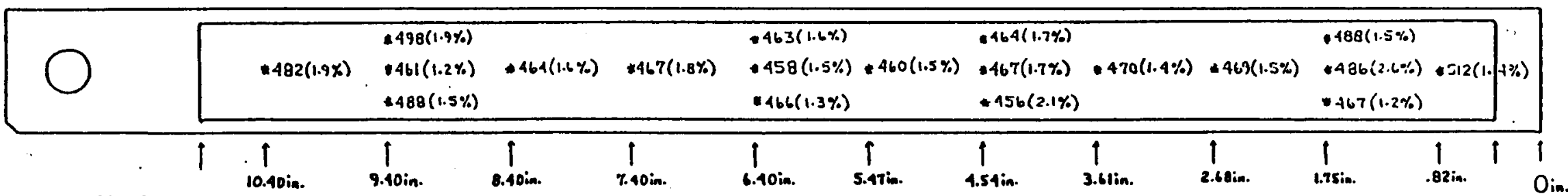

No. 6

RADIONUCLIDE: ${ }^{134} \mathrm{Cs}$

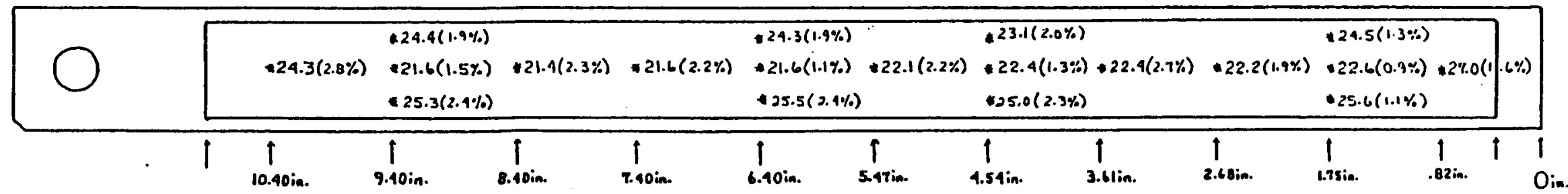


No. 6

RADIONUCLIDE: ${ }^{137} \mathrm{CS}$

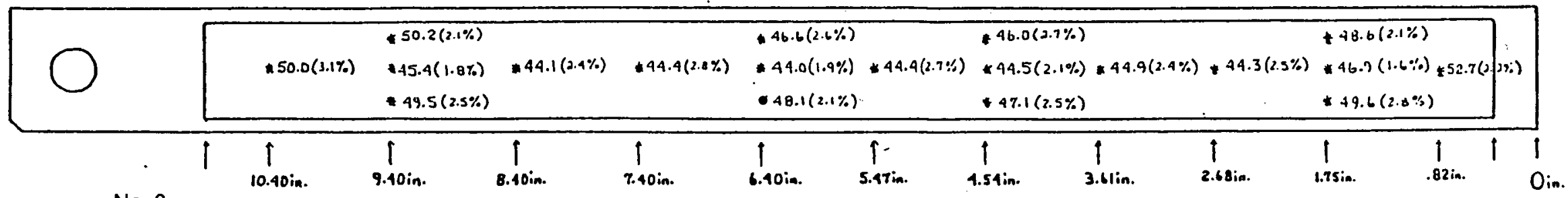

No. 6

RADIONUCLIDE: ${ }^{144} \mathrm{Ce}$

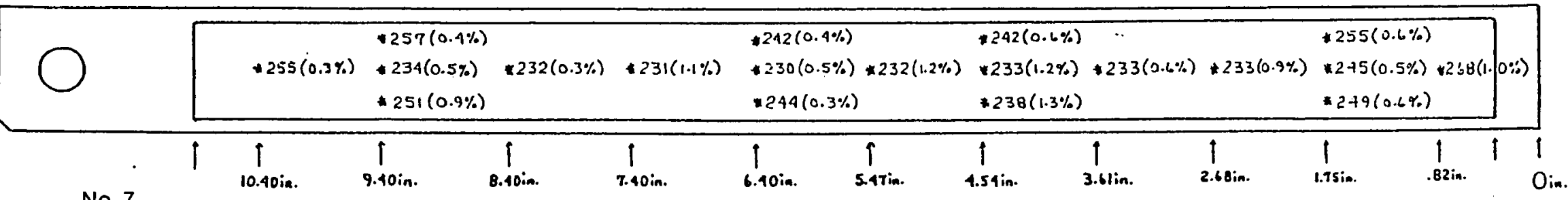

No. 7

RADIONUCLIDE: ${ }^{95} \mathrm{Zr}$

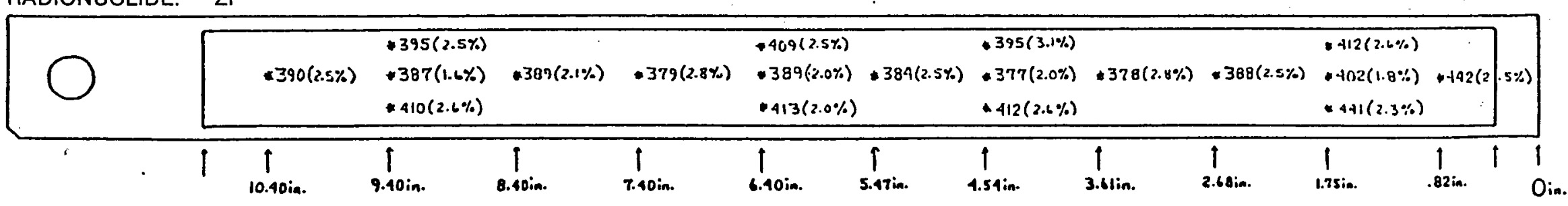

No. 7

RADIONUCLIDE: ${ }^{103} \mathrm{Ru}$

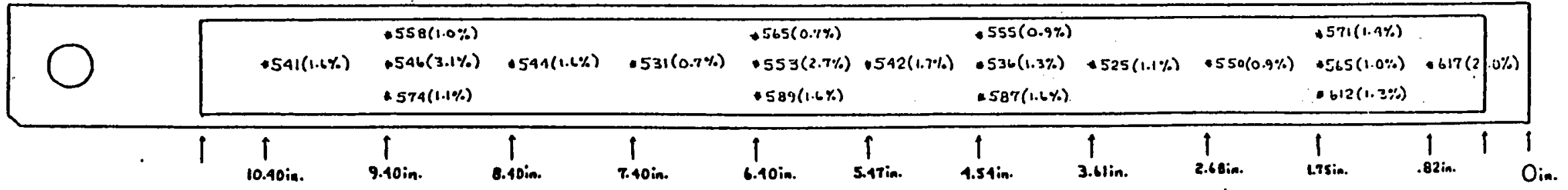


No. 7

RADIONUCLIDE: ${ }^{134} \mathrm{Cs}$

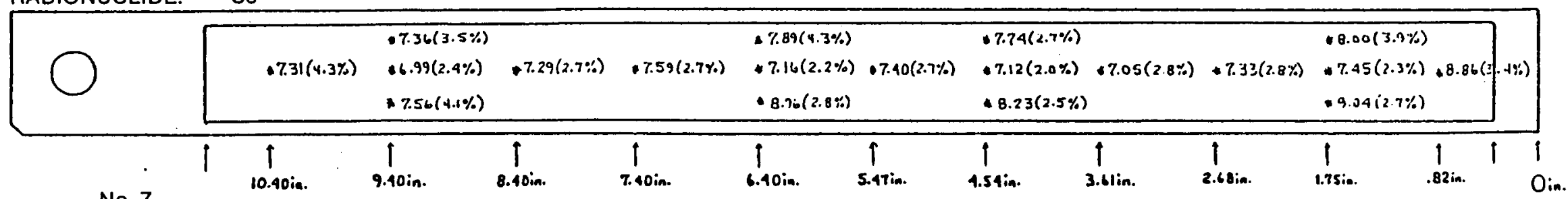

RADIONUCLIDE: ${ }^{137} \mathrm{Cs}$

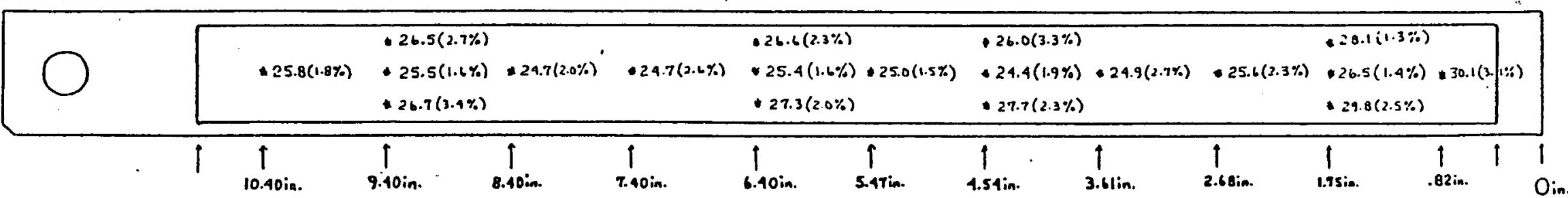

No. 7

RADIONUCLIDE: ${ }^{144} \mathrm{Ce}$

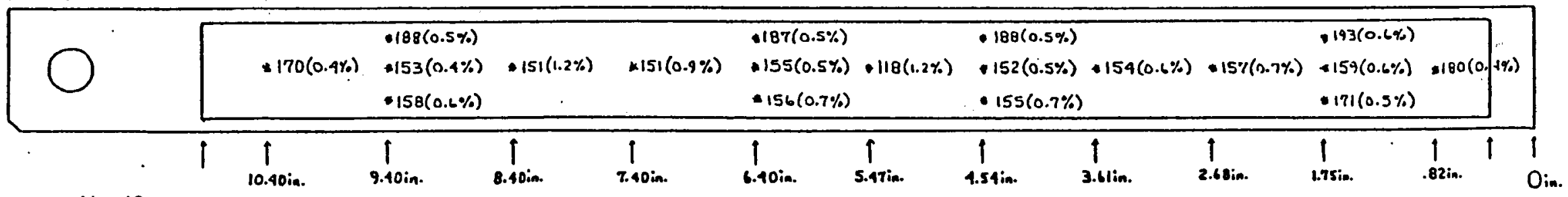

No. 13

RADIONUCLIDE: ${ }^{95} \mathrm{Zr}$

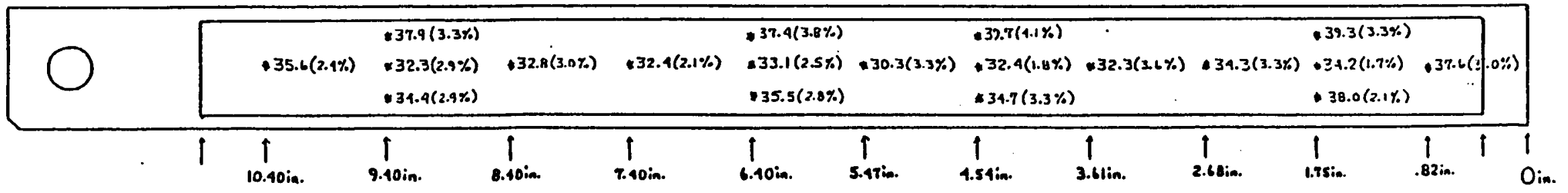


No. 13

RADIONUCLIDE: ${ }^{103} \mathrm{Ru}$

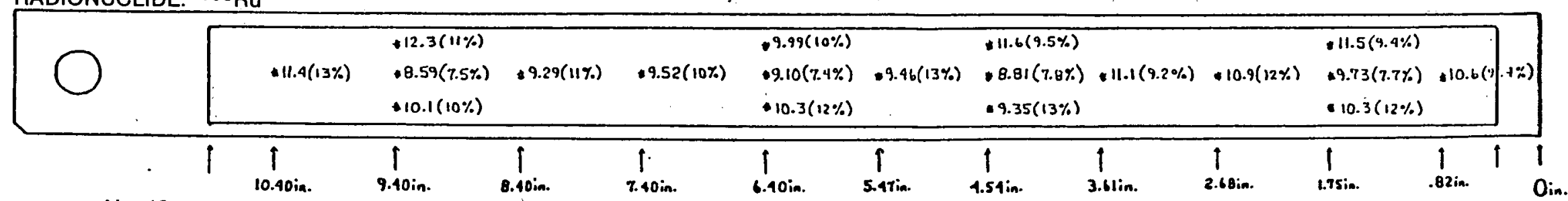

No. 13

RADIONUCLIDE: ${ }^{134} \mathrm{Cs}$

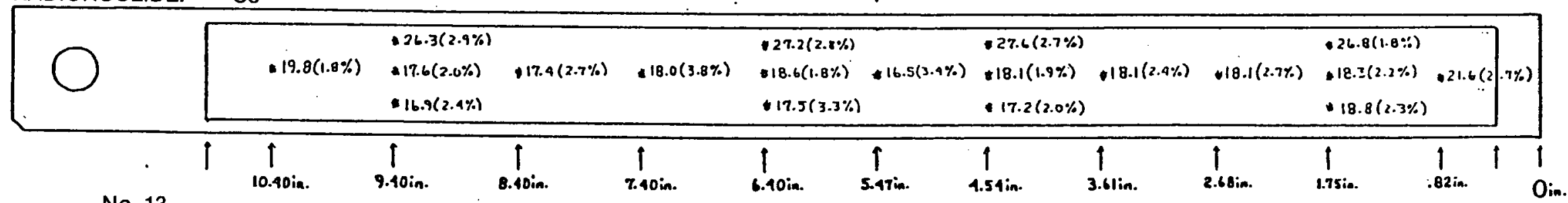

No. 13

RADIONUCLIDE: ${ }^{137} \mathrm{Cs}$

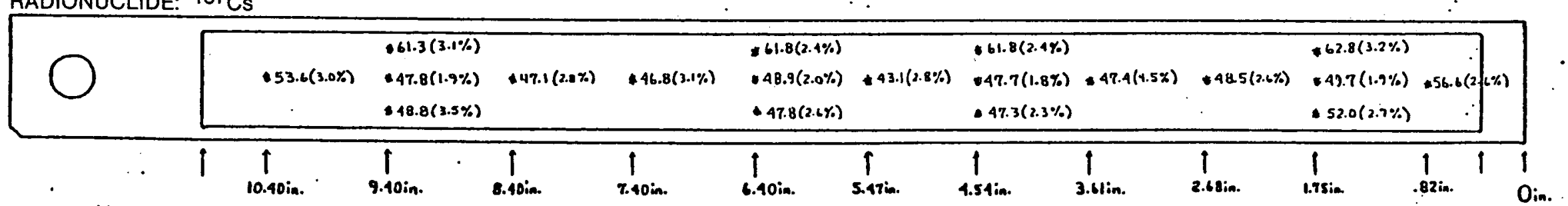

No. 13

RADIONUCLIDE: ${ }^{144} \mathrm{Ce}$

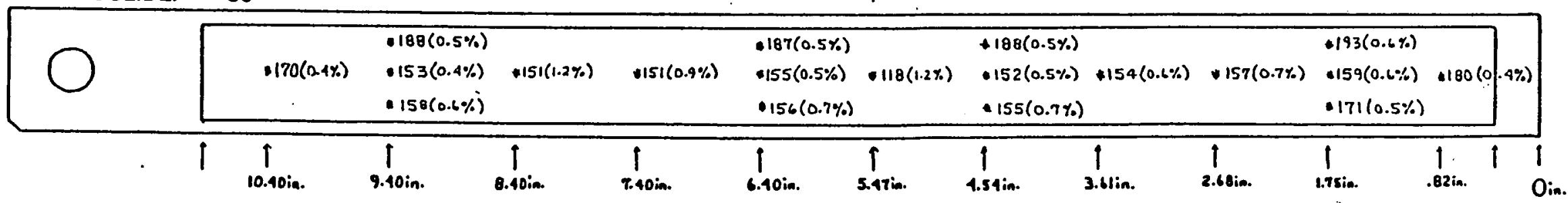


No. 19

RADIONUCLIDE: $95 \mathrm{Zr}$

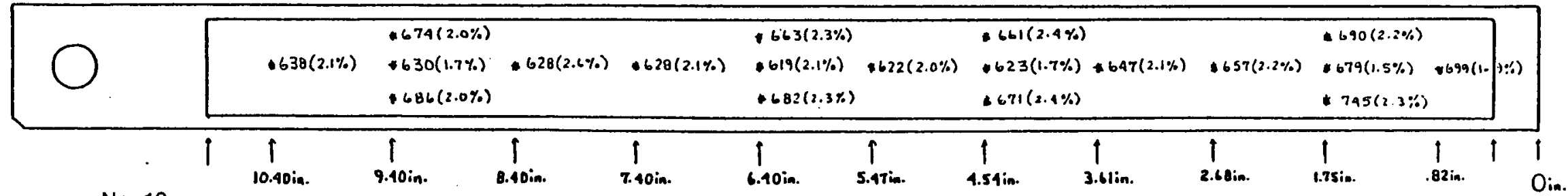

No. 19

RADIONUCLIDE: ${ }^{103} \mathrm{Ru}$

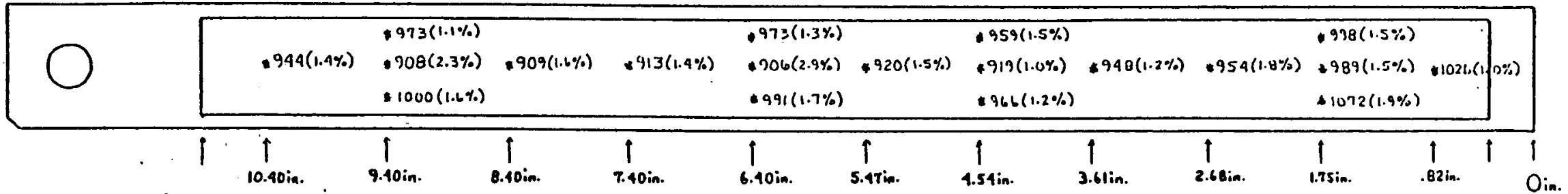

RADIONUCLIDE: ${ }^{134} \mathrm{Cs}$

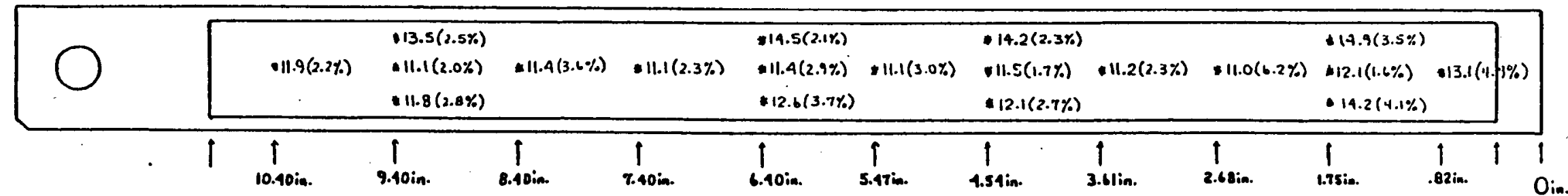

No. 19

RADIONUCLIDE: ${ }^{137} \mathrm{Cs}$

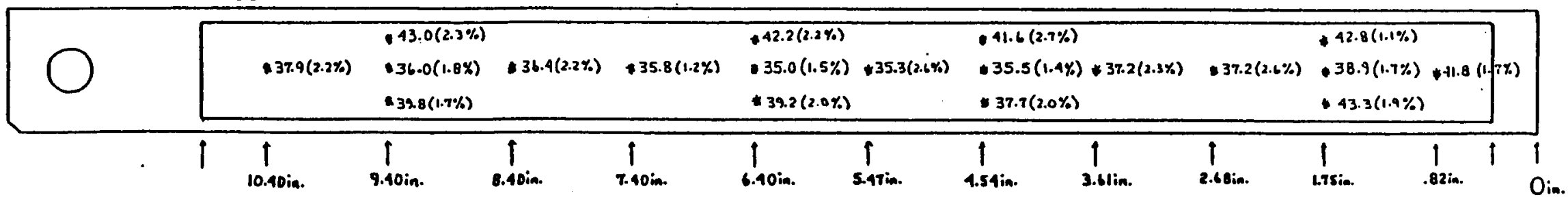


No. 19

RADIONUCLIDE: ${ }^{144} \mathrm{Ce}$

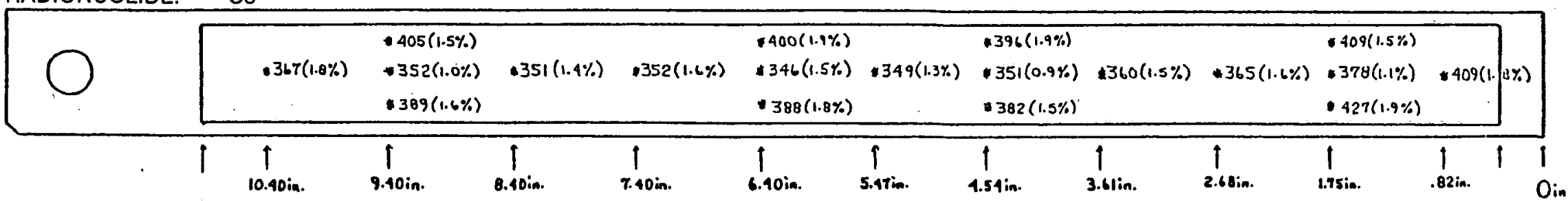

No. 20

RADIONUCLIDE: ${ }^{95} \mathrm{Zr}$

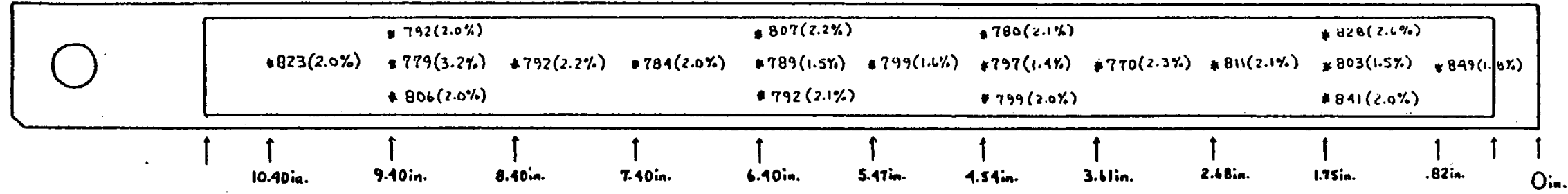

No. 20

RADIONUCLIDE: ${ }^{103} \mathrm{Ru}$

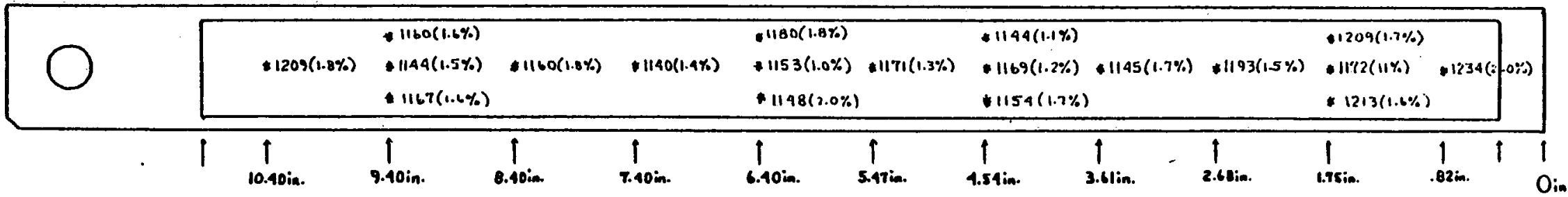

No. 20

RADIONUCLIDE: ${ }^{134} \mathrm{Cs}$

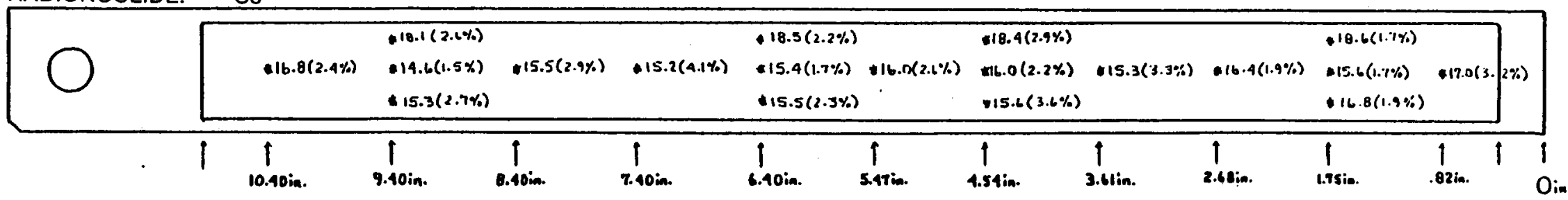


No. 20

RADIONUCLIDE: ${ }^{137} \mathrm{Cs}$

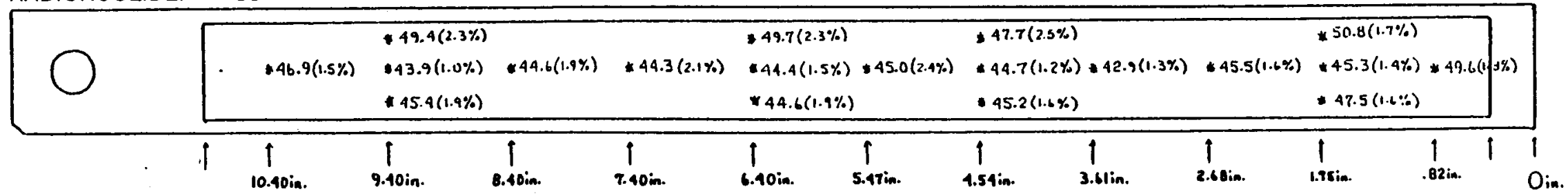

No. 20

RADIONUCLIDE: ${ }^{144} \mathrm{Ce}$

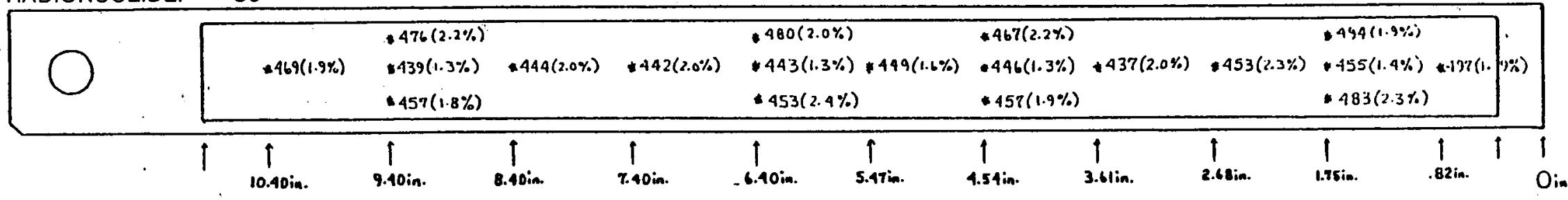

No. 22

RADIONUCLIDE: $95 \mathrm{Zr}$

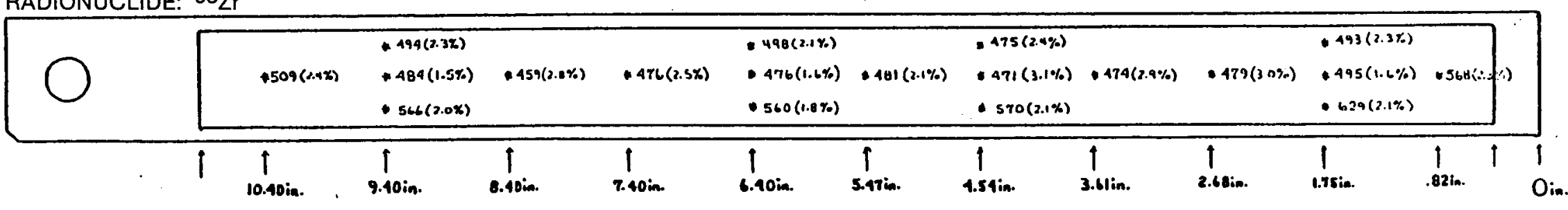

No. 22

RADIONUCLIDE: ${ }^{103} \mathrm{Ru}$

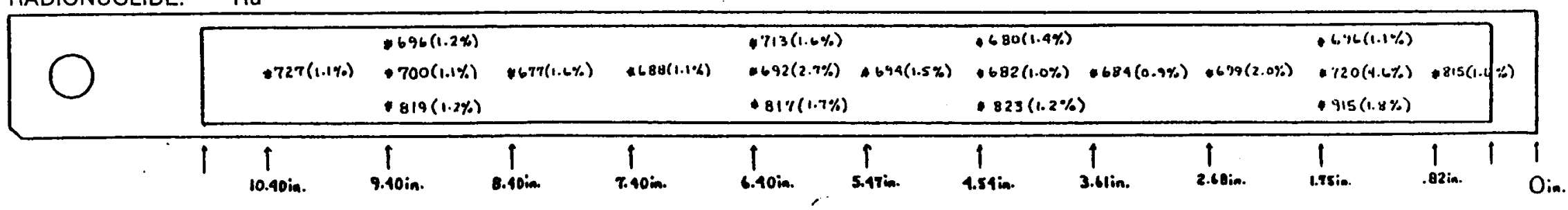


No. 22

RADIONUCLIDE: ${ }^{134} \mathrm{CS}$

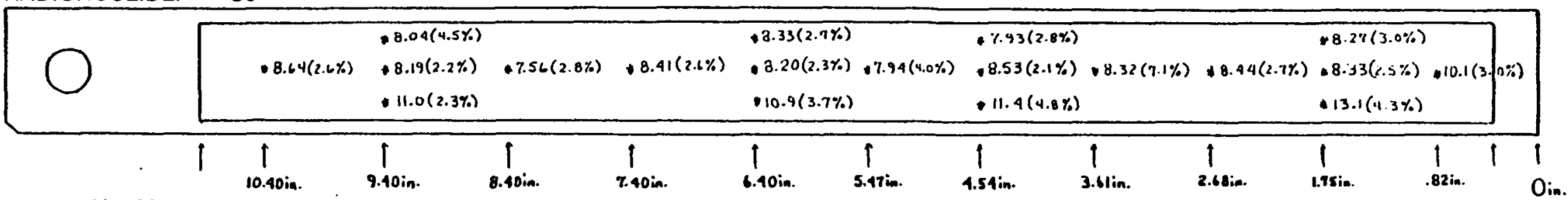

No. 22

RADIONUCLIDE: ${ }^{137} \mathrm{Cs}$

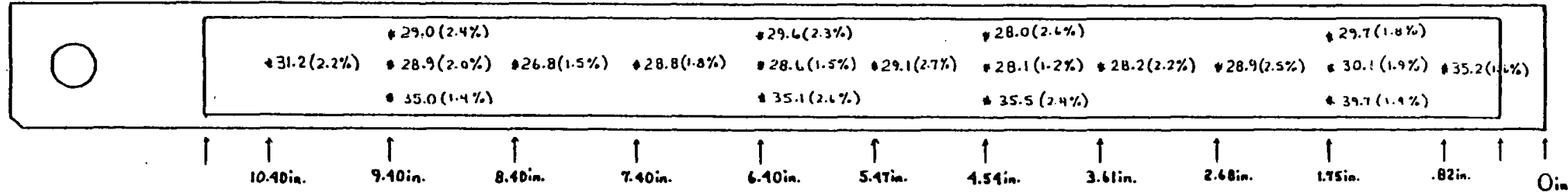

RADIONUCLIDE: ${ }^{144} \mathrm{Ce}$

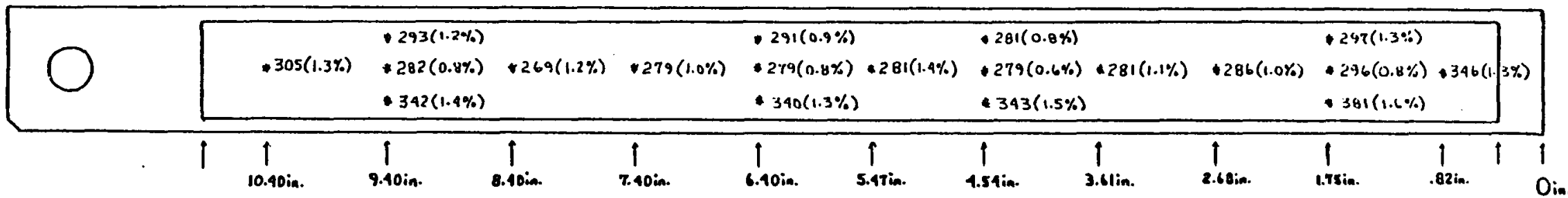

No. 27

RADIONUCLIDE: ${ }^{95} \mathrm{Zr}$

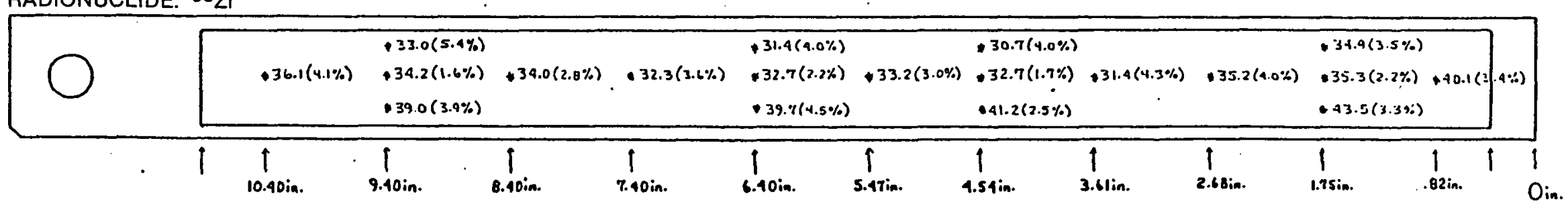


No. 27

RADIONUCLIDE: ${ }^{103} \mathrm{Ru}$

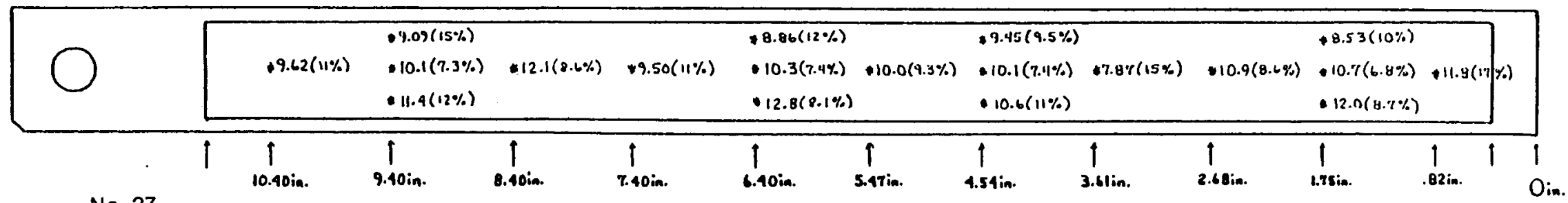

RADIONUCLIDE: ${ }^{134} \mathrm{Cs}$

\begin{tabular}{|c|c|c|c|c|c|c|c|c|c|c|c|}
\hline & \multirow{3}{*}{$\neq 0.71(3.5 \%)$} & \multicolumn{2}{|l|}{$.7 .65(3.2 \%)$} & \multirow{3}{*}{$4.53(2.4 \%)$} & \multicolumn{2}{|l|}{$.7 .94(2.7 \%)$} & \multicolumn{2}{|l|}{$.7 .62(1.9 \%)$} & \multicolumn{2}{|l|}{$.715(3.0 \%)$} & \multirow{3}{*}{.$(1 \%)$} \\
\hline & & $-7.79(1.3 \%)$ & $=7.70(2.9 \%)$ & & $.8 .13(1.9 \%)$ & $0.0 \%(3.1 \%)$ & $=0.05(1.7 \%) \cdot 7.95(3.0 \%)$ & $\$ 8.57(2.0 \%)$ & $.8 .40(1.69 \%)$ & $-10.1(2$. & \\
\hline & & - $11.2(2.7 \%)$ & & & $12.3(2.0 \%)$ & & $+12.6(2.3 \%)$ & & $=13.2(2.1 \%)$ & & \\
\hline$\cdot 1$ & $\uparrow_{10.40 \mathrm{in} .}$ & 9 & $.40 \mathrm{in.}$ & $1_{\text {r.40in. }}^{1}$ & $1_{6.10 \mathrm{in} .}$ & $\prod_{\text {S.47im. }}$ & $\underbrace{1}_{4.54 i n .}$ & $1_{8.68 \mathrm{in} .}$ & 1 & ${ }_{.82 \text { in. }}^{1}$ & 1 \\
\hline
\end{tabular}

UCLIDE: ${ }^{137}$ Cs

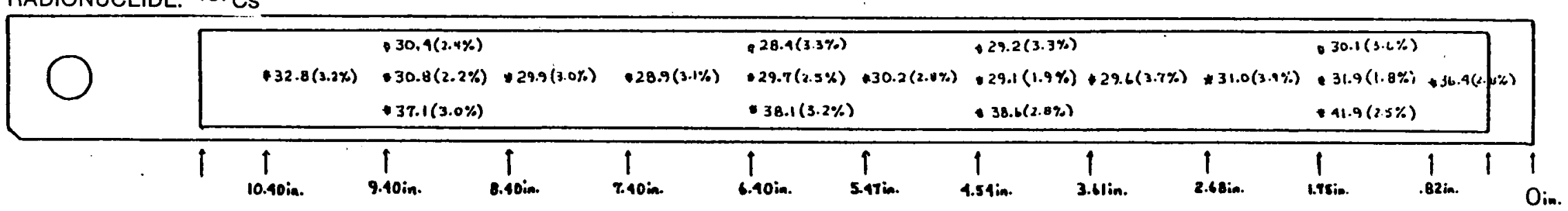

No. 27

RADIONUCLIDE: ${ }^{144} \mathrm{Ce}$

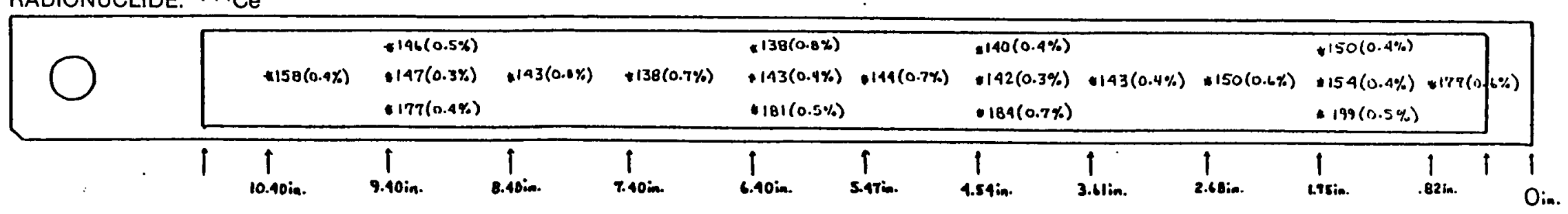


No. 28

RADIONUCLIDE: $95_{\mathrm{Zr}}$

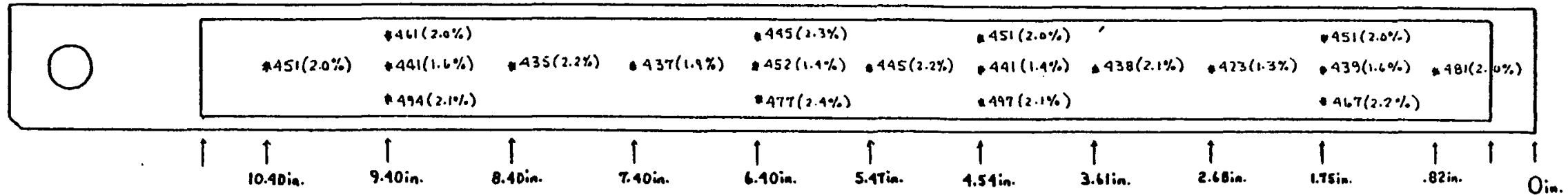

No. 28

RADIONUCLIDE: ${ }^{103} \mathrm{Ru}$

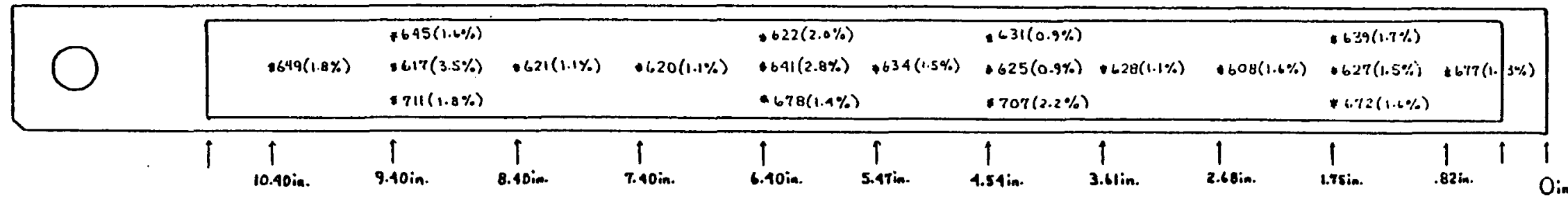

No. 28

RADIONUCLIDE: ${ }^{134} \mathrm{Cs}$

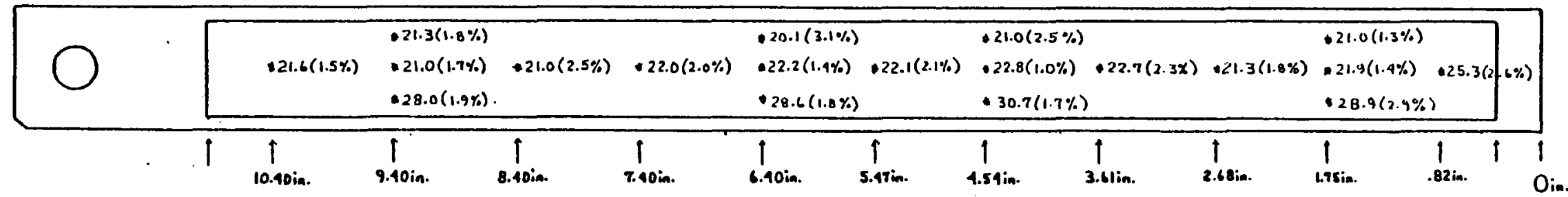

No. 28

RADIONUCLIDE: $137 \mathrm{Cs}$

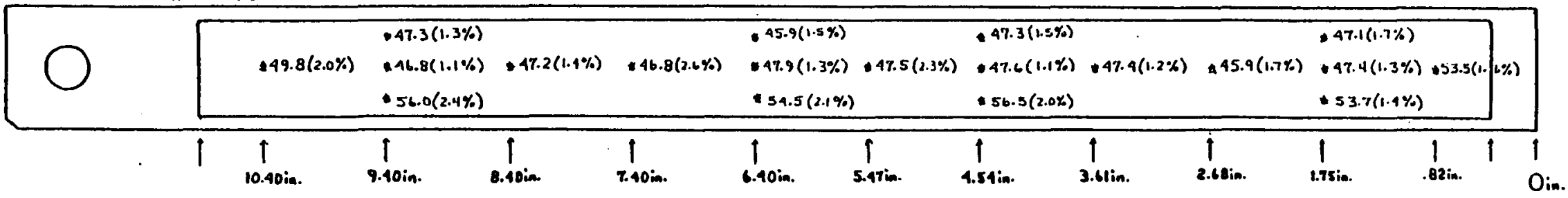


No. 28

RADIONUCLIDE: ${ }^{144} \mathrm{Ce}$

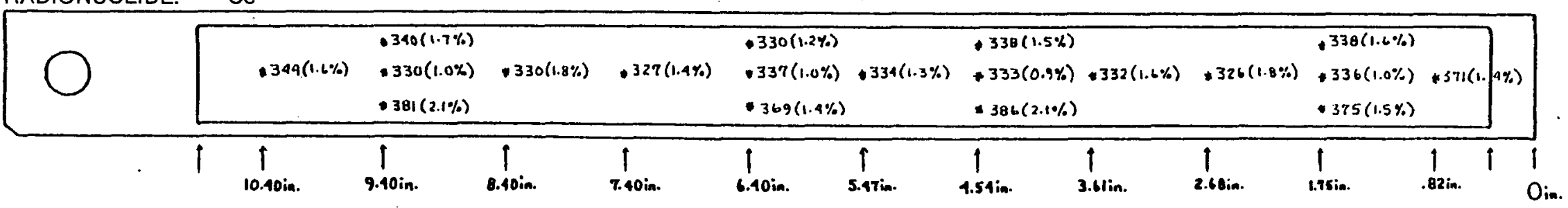

No. 30

RADIONUCLIDE: $95 \mathrm{Zr}$

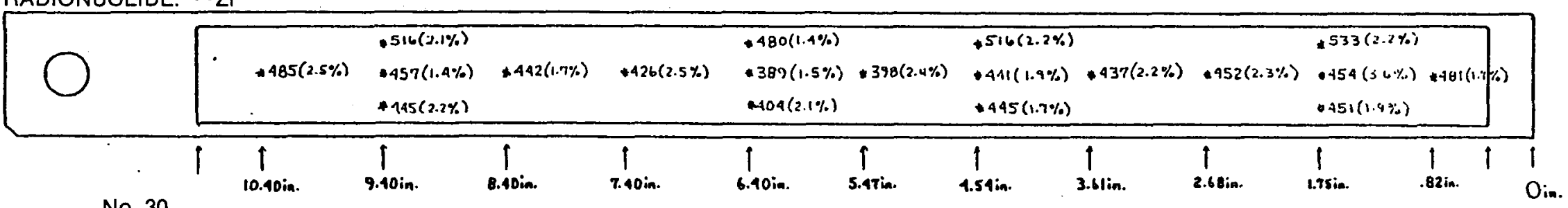

RADIONUCLIDE: ${ }^{103} \mathrm{Ru}$

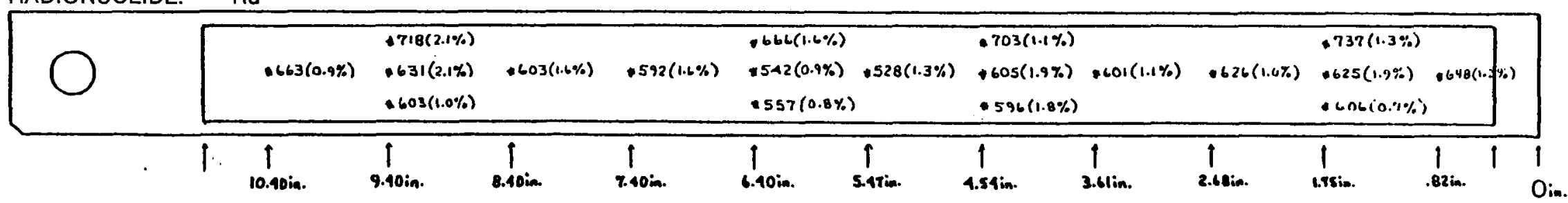

No. 30

RADIONUCLIOE: ${ }^{134} \mathrm{Cs}$

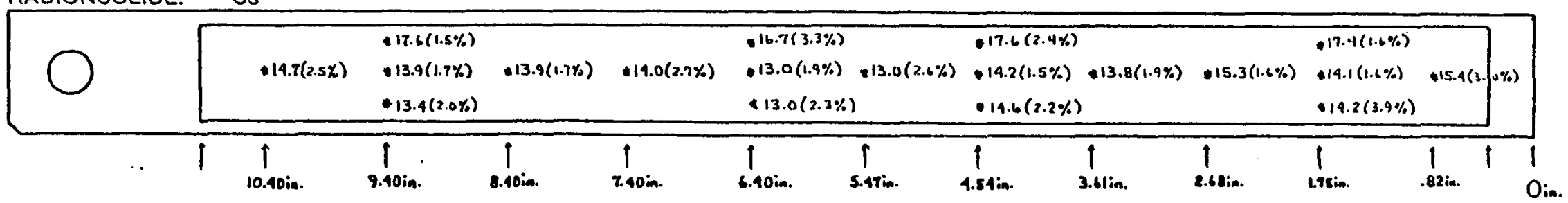


No. 30

RADIONUCLIDE: ${ }^{137} \mathrm{Cs}$

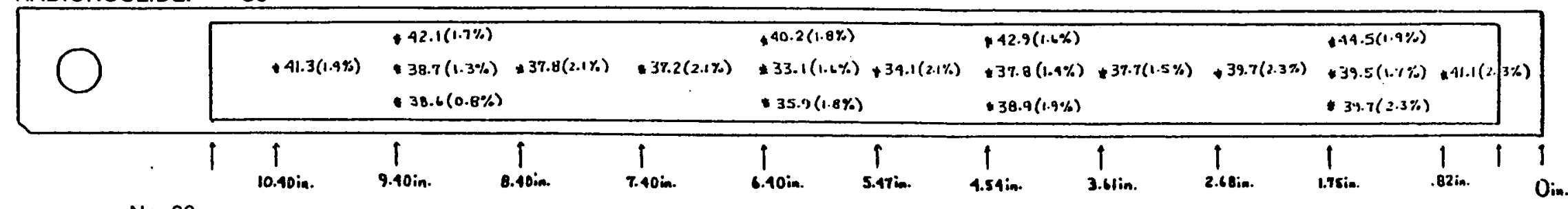

No. 30

RADIONUCLIDE: ${ }^{144} \mathrm{Ce}$

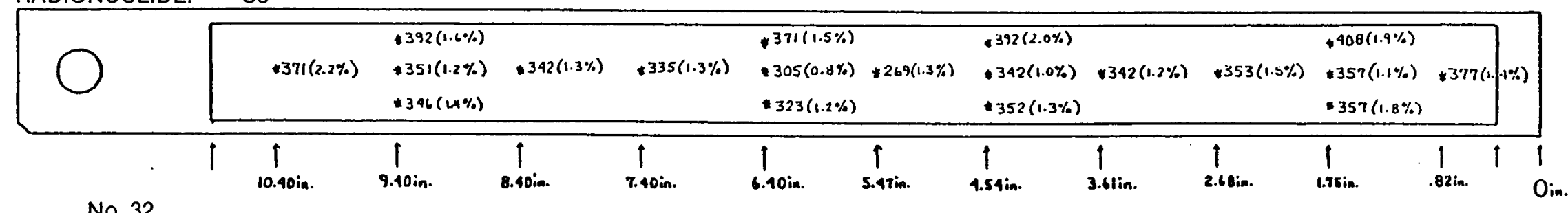

No. 32

RADIONUCLIDE: $95_{\mathrm{Zr}}$

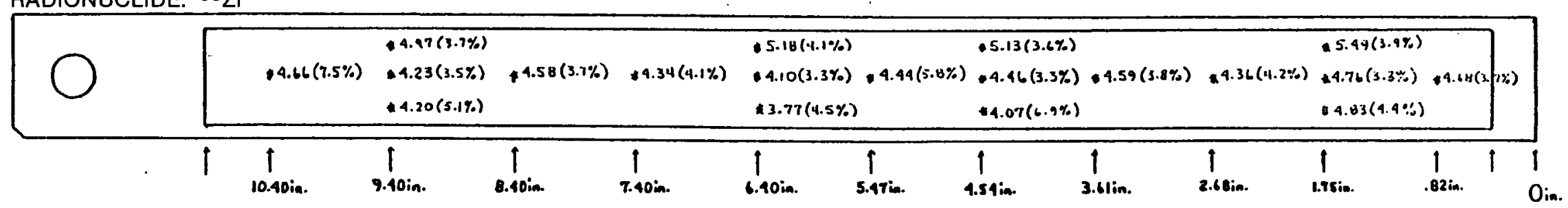

No. 32

RADIONUCLIDE: ${ }^{103} \mathrm{Ru}$-none detected-photo peak not observed.

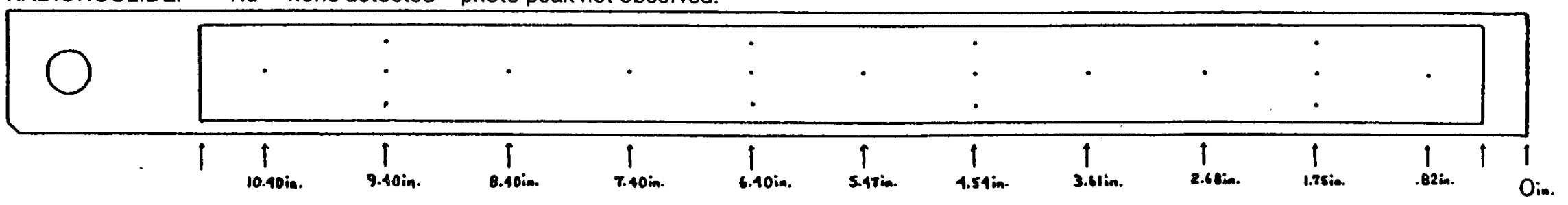


No. 32

RADIONUCLIDE: ${ }^{134} \mathrm{Cs}$

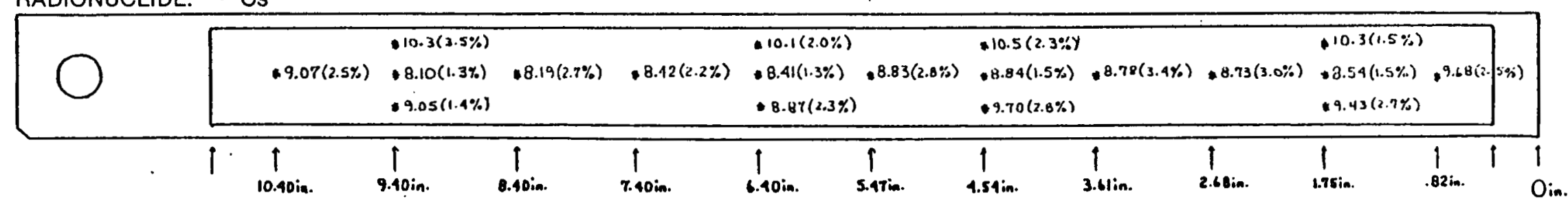

No. 32

RADIONUCLIDE: ${ }^{137} \mathrm{Cs}$

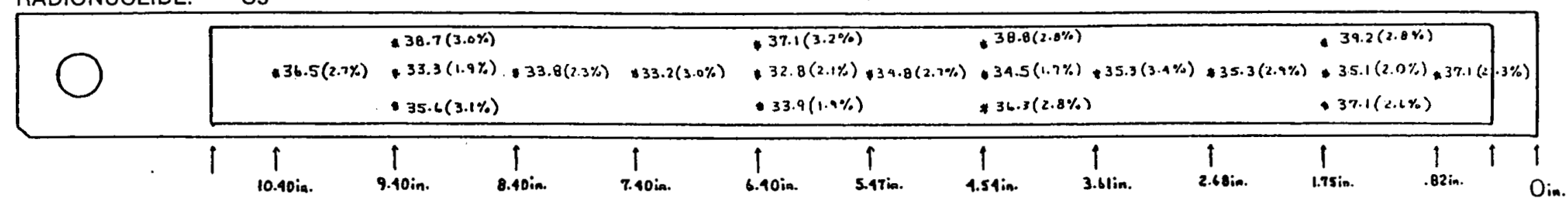

No. 32

RADIONUCLIDE: ${ }^{144} \mathrm{Ce}$

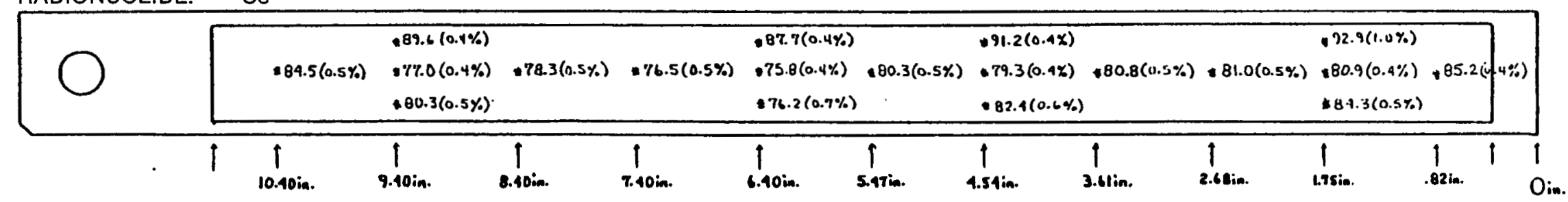

No. 33

RADIONUCLIDE: $95 \mathrm{Zr}$ - none detected.

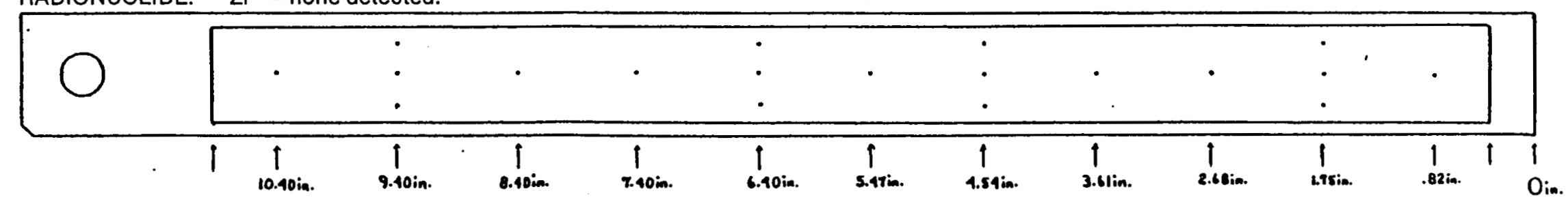


No. 33

RADIONUCLIDE: ${ }^{103} \mathrm{Ru}$ - none detected.

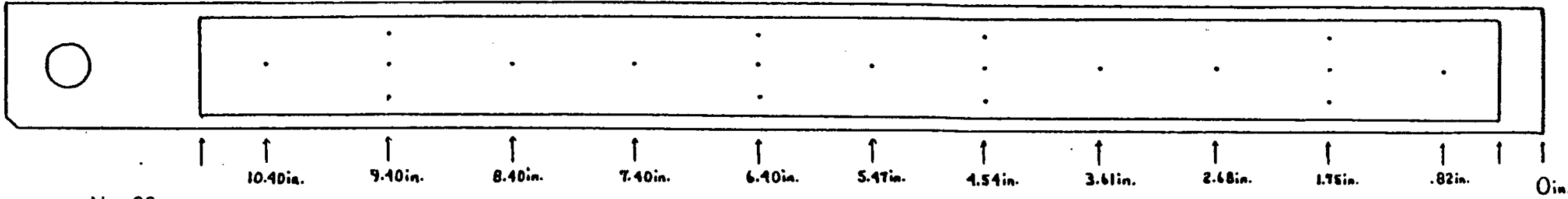

No. 33

RADIONUCLIDE: ${ }^{134} \mathrm{Cs}$

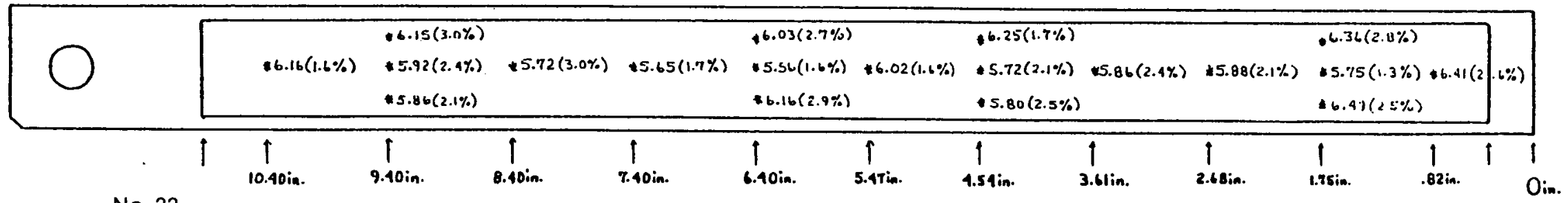

No. 33

RADIONUCLIDE: ${ }^{137} \mathrm{Cs}$

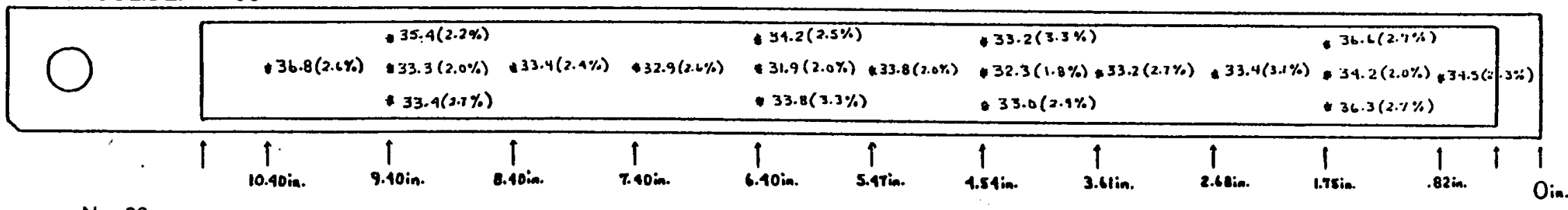

No. 33

RADIONUCLIDE: ${ }^{144} \mathrm{Ce}$

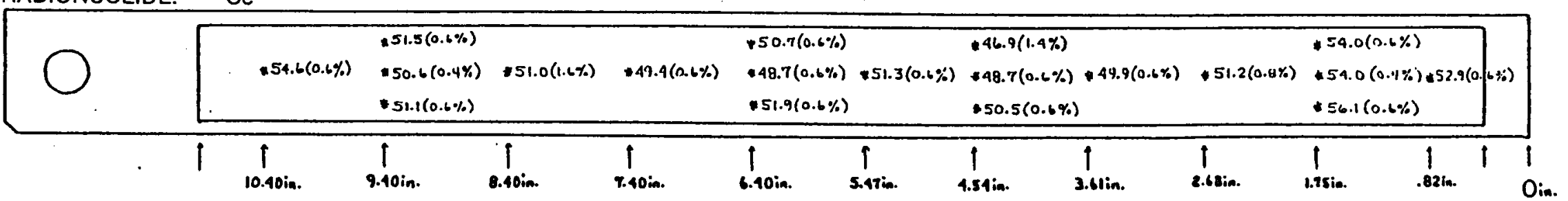


No. 32

RADIONUCLIDE: ${ }^{134} \mathrm{Cs}$

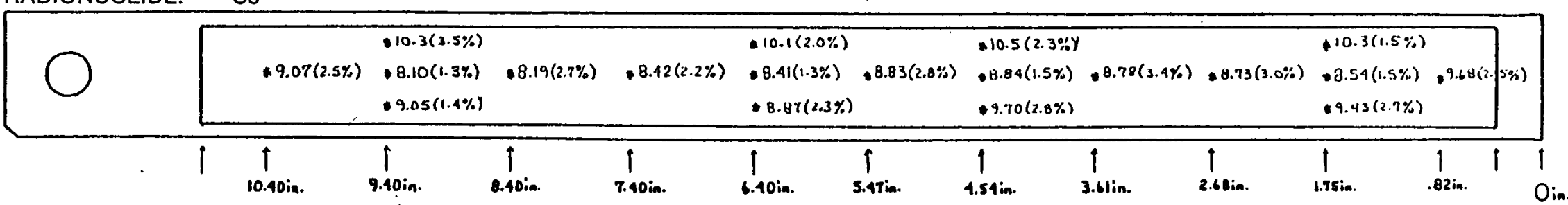

No. 32

RADIONUCLIDE: ${ }^{137} \mathrm{Cs}$

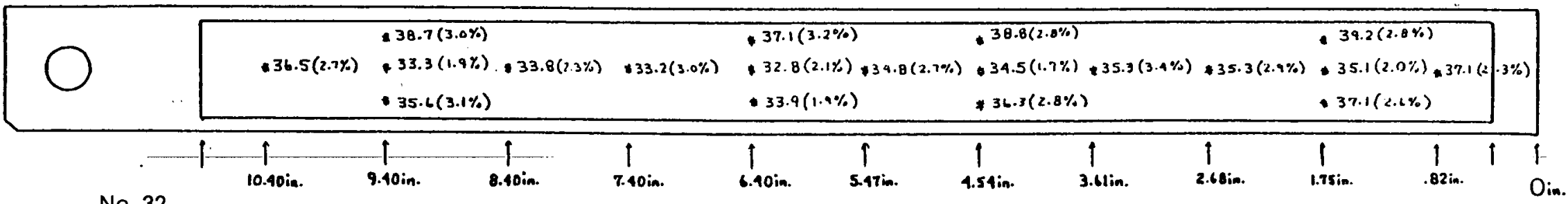

No. 32

RADIONUCLIDE: ${ }^{144} \mathrm{Ce}$

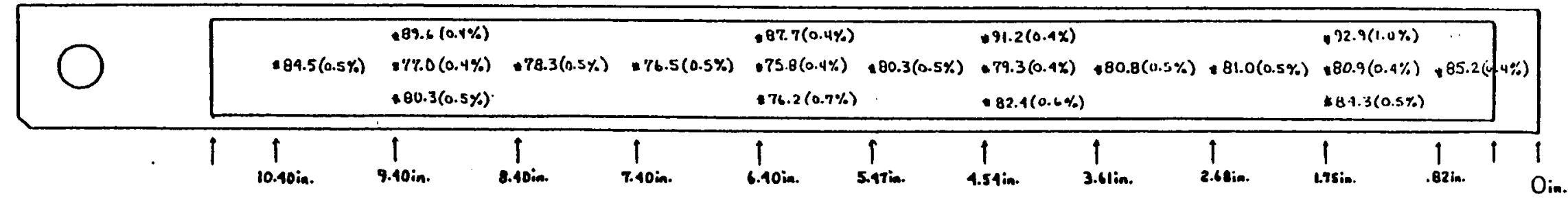

No. 33

RADIONUCLIDE: ${ }^{95} \mathrm{Zr}$ - none detected.

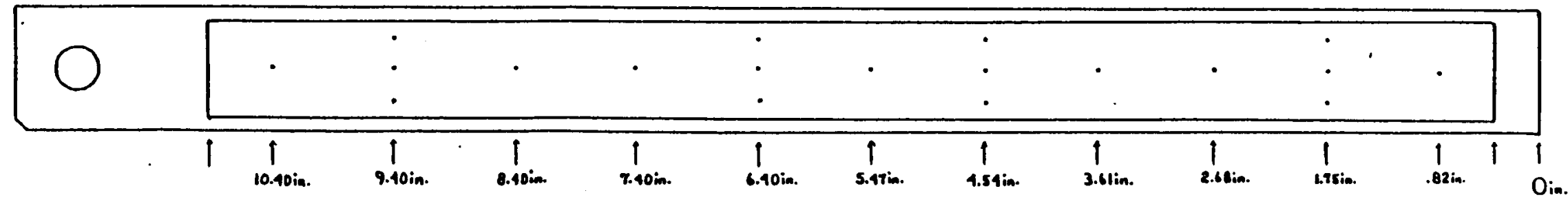


No. 33

RADIONUCLIDE: ${ }^{103} \mathrm{Ru}$ - none detected.

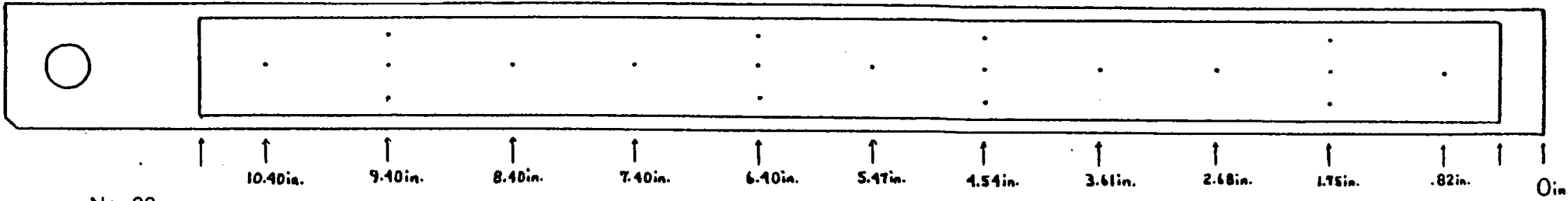

No. 33

RADIONUCLIDE: ${ }^{134} \mathrm{Cs}$

\begin{tabular}{|c|c|c|c|c|c|c|c|c|c|c|}
\hline & $.6 .16(1.6 \%)$ & $\begin{array}{l}.6 .15(3.0 \%) \\
.5 .92(2.4 \%) \\
.5 .86(2.1 \%)\end{array}$ & $5.72(3.0 \%)$ & $.5 .65(1.7 \%)$ & $\begin{array}{l}16.03(2.7 \%) \\
.5 .56(1.6 \%) \\
.6 .16(2.9 \%)\end{array}$ & $.6 .02(1.6 \%)$ & $\begin{array}{l}.6 .25(1.7 \%) \\
.5 .72(2.1 \%) \quad 45.86(2.4 \%) \\
+5.80(2.5 \%)\end{array}$ & $* 5.88(2.1 \%)$ & $\begin{array}{l}.6 .36(2.0 \%) \\
.5 .75(1.3 \%) \\
.6 .4)(2.4 \%) \\
\end{array}$ & $.6 \%$ \\
\hline † & $\prod_{10.40 \mathrm{ia} .}^{\uparrow}$ & $\prod_{9.10 \mathrm{in} .}^{1}$ & $\prod_{\text {8.40in. }}$ & $\prod_{\text {7.40in. }}$ & \rceil$_{6.10 \mathrm{in} .}$ & $\uparrow_{5.47 \mathrm{in.} .}$ & $\begin{array}{l}1 \\
1.54 \mathrm{in} .\end{array}$ & 1 & $1_{.82 \text { in. }}^{1}$ & 1 \\
\hline
\end{tabular}

No. 33

RADIONUCLIDE: ${ }^{137} \mathrm{Cs}$

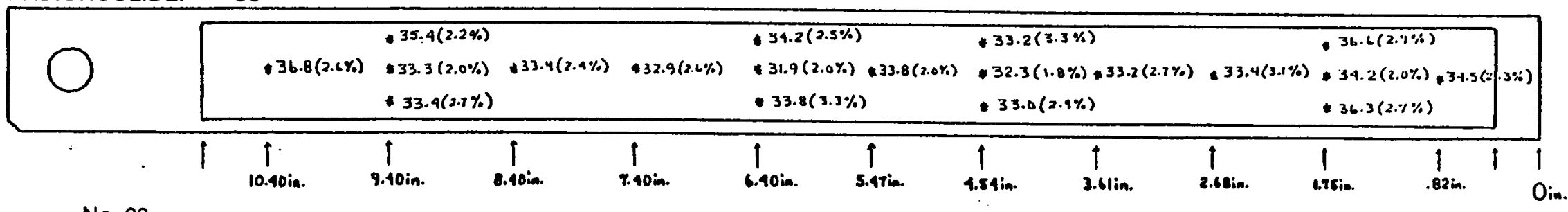

No. 33

RADIONUCLIDE: ${ }^{144} \mathrm{Ce}$

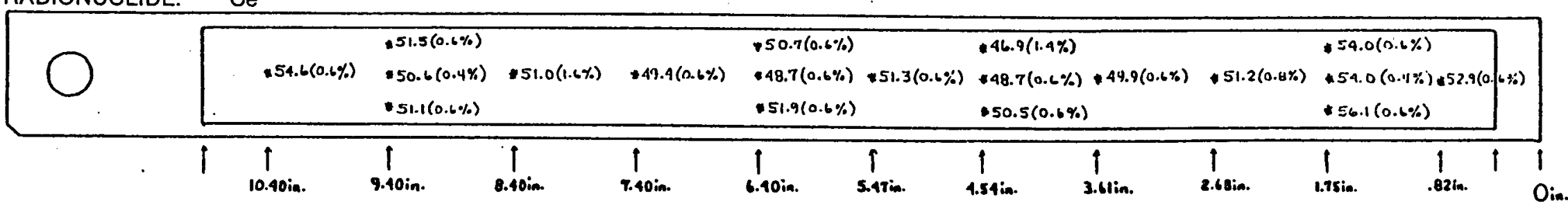

